\title{
University of Michigan Law School University of Michigan Law School Scholarship Repository
}

1954

\section{Integration of Public Utility Holding Companies}

Robert F. Ritchie

Follow this and additional works at: http://repository.law.umich.edu/michigan_legal_studies

Part of the Antitrust and Trade Regulation Commons, Business Organizations Law Commons, Energy and Utilities Law Commons, and the Securities Law Commons

\section{Recommended Citation}

Ritchie, Robert F. Integration of Public Utility Holding Companies. Ann Arbor: University of Michigan, 1954.

This Book is brought to you for free and open access by the Law School History and Publications at University of Michigan Law School Scholarship Repository. It has been accepted for inclusion in Michigan Legal Studies Series by an authorized administrator of University of Michigan Law School Scholarship Repository. For more information, please contact mlaw.repository@umich.edu. 
MICHIGAN LEGAL STUDIES

\section{- \\ INTEGRATION OF PUBLIC UTILITY \\ HOLDING COMPANIES}

PUBLISHED UNDER THE AUSPICES OF THE UNIVERSITY OF MICHIGAN LAW SCHOOL (WHICH, HOWEVER, ASSUMES NO RESPONSIBILITY FOR THE VIEWS EXPRESSED) WITH THE AID OF FUNDS DERIVED FROM GIFTS TO THE UNIVERSITY OF MICHICAN BY WILLIAM W. COOK. 
COPYRIGHT, 1955

BY

UNIVERSTITY OF MICHIGAN 
To

My Wife

Catherine Canfield Ritchie 


\section{MICHIGAN LEGAL PUBLICATIONS}

\section{Hessel E. Yntema, Editor}

Michigan Legal Studies

Discovery Before Trial

George Ragland, Jr.

Torts in the CONFLict of Laws Moffatt Hancock

The Amending of the Federal Constitution

Lester B. Orfield

REVIEW OF ADMINISTRative Acts Armin Uhler

The Prevention of Repeated CRIME

John Barker Waite

The Conflict of Laws: A ComParative StUdY-ThreE VOLUMES

Ernst Rabel

UNREPORTED OPINIONS OF THE SU. PREME COURT OF MiCHIGAN I 836-1 943

William Wirt Blume, Editor

Problems in Probate LaW: INCluding a Model Probate CODE

Lewis M. Simes and Paul E. Basye

Soviet Civil LaW-Two VolUMES

Vladimir Gsovski

SURvey of Metropolitan

COURTS: DetroIt AREA

Maxine Boord Virtue

ADMinistrative Agencies AND THE COURTS

Frank E. Cooper

OUR Legal System and How IT OpERates

Burke Shartel

Retroactive Legislation AFFECTING INTERESTS IN LAND

John Scurlock

Integration of Public Utility Holding Companies

Robert F. Ritchie
UnIVERSITY OF MrChigan

Publications: LaW

Transactions of the SUPREME COURT OF THE TERRITORY OF Michigan, I 805-1836 Six Volumes

William Wirt Blume, Editor

Ratification of THE TWENTY-

FIRST AMENDMENT TO THE

CONSTITUTION OF THE

UNITED STATES

Everett S. Brown, Copiler

Cooley Lectures

The Constitution and SocioECONOMIC Change

Henry Rottschaefer

Some Problems of EQUity

Zechariah Chafee, Jr.

OUR Legal System and How It OPERATES

Burke Shartel

(published in Michigan Legal Studies)

SELECTED TOPICS ON THE LAW OF TORTS

William Prosser

Legislative Research

Center

Current Trends in State LegisLATION : 1952

Summer Institưte Lectures

THE CONFLict OF LAWS AND INTERNATIONAL CONTRACTS: 1949

The Law and Labor-ManageMENT RELATIONS: I950

TaXation of Business ENTERPRISE: 1951

ATOMIC ENERGY-INDUSTRIAL AND Legal Problems: 1952

Federal Antitrust LaWs: 1953 


\title{
INTEGRATION OF PUBLIC UTILITY HOLDING COMPANIES
}

\author{
By \\ ROBERT F. RITCHIE
}

\section{Foreword}

by

LAYLin K. James

\author{
Ann Arbor \\ University of Michigan LaW School \\ I954
}




\section{Foreword}

$7 \mathrm{HE}$ financial and economic orgies of the I920's not only resulted in securities controls acts but also economic controls acts. One of the most important of the latter is the Public Utility Holding Company Act of 1935. It combines securities and economic controls and places tremendous power of control over public utility companies with the Securities and Exchange Commission. Section I I (b) of that Act required the Commission as soon as practicable after January I, 1938, to take action to limit the operations of each holding company and each subsidiary company thereof to a "single integrated public utility system" and "to such other businesses as are reasonably incidental, or economically necessary or appropriate to the operations of such integrated public utility system." This popularly described "death sentence" provision is the basis of Mr. Ritchie's study. As was true of all the early New Deal legislation restricting business activities formerly carried on, the Holding Company Act, and particularly Section I I(b), was subjected to all the legal attacks under the Constitution and survived, as is pointed out by Mr. Ritchie.

The economic consequences of enforcing integration can only be answered by time and experience. Mr. Ritchie's careful and thoughtful analysis of the Commission's developing attitudes and rules in the process of effecting the admonition of Congress, his conclusions on the effects of integrations thus far completed and in process, as well as the accumulation of the factual data, form a valuable document for utility executives, their lawyers, and the general public interested in utility problems. Mr. Ritchie has performed a valuable service.

LaYlin K. James 


\section{Preface}

7 HE Public Utility Holding Company Act of 1935 was one of the most controversial pieces of legislation ever 1 enacted by Congress, but despite this fact it has withstood numerous and vigorous attacks upon its constitutionality and, further, it has never been amended in any material respect. The Securities and Exchange Commission was confronted in 1935 with one of the most difficult administrative tasks in modern history. How it met and resolved the difficult problems of geographical and economic integration, arising under the so-called "death sentence" provisions of this Act, is the subject matter of this publication.

The research involved in the preparation of this book included the examination and study of the legislative history of the Act, contemporaneous legal, economic and political comment, all court decisions concerning the problem of integration, and all of the official releases of the Securities and Exchange Commission issued under the Public Utility Holding Company Act of 1935, through release number I 1606, dated November 28, 1952. All decisions of consequence issued by the Commission pertaining to integration are cited herein. As of this date the U.S. Government Printing Office has published only twenty volumes of the Commission's decisions, the latest release published therein being dated October I2, I 945. Consequently, citations to releases after this date can only refer to release numbers and their dates. For convenience in referring to releases which do not appear in the bound volumes, the exact dates of such releases have been included in the footnotes. The Securities and Exchange Commission decisions included in the bound volumes are set forth in chronological order and releases published in such volumes 
in the future may therefore be readily located by the date reference.

All of the illustrative maps were taken from official Securities and Exchange Commission releases. The enclosures indicating the extent of integrated systems on these maps have been added for the purposes of this book, however.

Robert F. Ritchie

Dallas, Texas

December I, I 952 


\section{Table of Contents}

PAGE

Foreword by LAYLin K. James . . . . . . . . vii

Preface ...................... ix

Chapter i. Introduction to Integration ..... i i

Advantages and Disadvantages of Public Utility

Holding Companies ...............

Legislative History of the Public Utility Holding

Company Act of $1935 \ldots \ldots \ldots \ldots \ldots$ I5

Constitutionality of the Act ........... I9

Chapter 2. Definition of Integration ...... 25

Selection of the Principal System ......... 33

Integration as Applied to Particular Electric

Utility Systems ................ 37

Standard Power \& Light Corporation . . . . . . 38

The United Gas Improvement Company .... 39

American Water Works \& Electric Company 40

Engineers Public Service Company ....... 40

The North American Company .......... 44

Cities Service Power \& Light Company ..... 5 I

The Commonwealth \& Southern Corporation. . 60

The Middle West Corporation .......... 64

American Gas \& Electric Company ....... $\quad 77$

I. The Central System ............. 79

2. The Northeast Pennsylvania System .. 90

3. The South Jersey System ......... 90

General Public Utilities Corporation ...... 90

Summary of Electric Utility Integration . . 93 
PAGE

Integration as Applied to Particular Gas Utility Systems .................... 95

Engineers Public Service Company ....... 97

Standard Power \& Light Corporation . . . . . . 97

Community Gas \& Power Company ........ 98

Columbia Gas \& Electric Corporation ...... 99

Pennsylvania Gas \& Electric Corporation .... IO 103

Southern Union Gas Company ......... 105

Cities Service Company ............. I07

I. The Mid-Continent Properties ...... I07

2. Arkansas Louisiana Gas Company System 108

3. The Northern Properties . . . . . . . . . 108

Lone Star Gas Corporation ............ 109

The United Light \& Railways Company . . . I I 2

The North American Company ......... $\quad$ I23

The Mission Oil Company ........... I I I

General Public Utilities Corporation ....... I 132

Summary of Gas Utility Integration ..... I 33

Chapter 3. The Retention of Additional Systems

A. Loss of Substantial Economies ......... I I36

Republic Electric Power Corporation ..... 136

The North American Company ......... I 37

Engineers Public Service Company ...... 147

Cities Service Power \& Light Company ... I $\quad$ I 57

Cities Service Company .............. I64

The Middle West Corporation ......... I67

Philadelphia Company ............. I69

Eastern Utilities Associates ............ I 75

Lone Star Gas Corporation ............ $\quad$ I 77

Columbia Gas \& Electric Corporation ...... $\quad$ I 78

Peoples Light \& Power Company ........ I 79

American Gas \& Electric Company ....... r 8 I 
PAGE

General Public Utilities Corporation

I 82

Summary of the Requirements of Clause A $\quad$ I87

B. Geographical Proximity ............ I9I

Summary of the Requirements of Clause B 202

C. The Size Requirement: Localized Management, Efficient Operation, and Effectiveness of Regulation ............. 205

The North American Company ........ 206

Engineers Public Service Company ....... 210

Southern Union Gas Company ......... 2 I 5

Lone Star Gas Corporation ........... 216

Cities Service Power \& Light Company ... 217.

The Middle West Corporation ......... 220

Columbia Gas \& Electric Corporation . . . . . 222

American Gas \& Electric Company ....... 223

The Commonwealth \& Southern Corporation 224

Summary of the Requirements of Clause C 226

Chapter 4. The Retention of Other Businesses 230

Investments . . . . . . . . . . . . . 244

Coal ...................... 250

Production and Transmission of Gas ........ 253

Production and Sale of Petroleum Products .... 260

Transportation ..................... 262

Steam and Hot Water ............. $27 \mathbf{I}$

Water ...................... $\quad 274$

Ice and Cold Storage ............... 277

Appliances .................... 280

Service Companies . . . . . . . . . . . . . . $\quad 282$

Real Estate and Related Enterprises ....... 283

Miscellaneous ................... 286

Summary of the Requirements of the Other Businesses Clauses ............. 289 
PAGE

Chapter 5. Conclusion ............. 293

Appendix. Compilation of Pertinent Provisions of the Public Utility Holding Company Act of r $935 \ldots \ldots \ldots \ldots \ldots \ldots \ldots \ldots \ldots$

Table of Cases $\ldots \ldots \ldots \ldots \ldots \ldots \ldots \ldots \ldots$

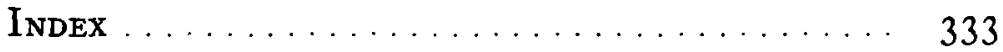




\section{Table of Illustrations}

American Gas \& Electric Company Electric Utility Systems .................... 78

Cities Service Power \& Light Company Electric Utility Systems .................... 52

The Commonwealth \& Southern Corporation Electric Utility Systems ................... 6r

Engineers Public Service Company Electric Utility Systems $\ldots \ldots \ldots \ldots \ldots \ldots \ldots \ldots \ldots \ldots, 42$

The Middle West Corporation Electric Utility Systems 65

The North American Company Electric Utility Systems 45 


\section{Chapter 1}

\section{Introduction to Integration}

\section{$A^{\mathrm{T}}$ HIS trial for use of the mails to defraud Samuel Insull explained to the jury his early association with Thomas A. Edison in the electric light business. On} one occasion Edison requested Insull to take charge of Edison General Electric Company, the forerunner of the present General Electric Company. The inventor's instructions were as follows: "Now, you go back up there and run the institution. And whatever you do, Sammy, make either a brilliant success of it or a brilliant failure." History has closed the record of Samuel Insull, and it reveals that he was both a brilliant success and a brilliant failure. At the age of 50 Insull had Chicago in his vest pocket. He was known as the "Maecenas of the Middle West" and the "uncrowned king of Illinois." One writer dubbed his city "Insullopolis." In connection with raising capital for his companies Insull was one of the few men who did not ask the bankers. He told them. During the decade of the r920's bankers begged him to accept loans and genuflected when he consented. A Chicago reporter once remarked that it was worth a million dollars to any man to be seen talking to Sam Insull in front of the Continental Bank. ${ }^{3}$ The only man who approached him in the field of public utilities was Sidney Z. Mitchell, the financial genius of the Electric Bond and Share Company system. These two men were rated by the industry as the Titans of electric power. They were deemed to be the industry's "Alpha and Omega." Subsequent events proved that the "Alpha" was Insull. ${ }^{4}$

\footnotetext{
${ }^{1}$ Busch, Francis X., GuIlty oR Not Guilty? 168 (1952).

2 Ramsay, M. L., Pyramids of Power, 56 (1937).

Id. at $22 \mathrm{I}$.

Id. at $44-45$.
} 
Intoxicated with the power growing out of a long career of apparent success, Insull expanded his enterprises far beyond the realm of economic reason and the resultant crash brought his empire tumbling down upon him like a house of cards. The reverberations of his collapse led to the demoralization of other utility holding companies and caused general consternation in the utilities securities market. The stock of Insull's Middle West Utilities Company depreciated in market value from a high in 1929 of $\$ 57$ per share to a low in 1932 of 25\%. His Midland United Company stock had declined from a high of $\$ 47$ in 1930 to a low of $\$ I$ in I 932. People's Gas Light and Coke Company declined from $\$ 435$ in 1929 to $\$ 40$ in 1932. Commonwealth Edison Company stock went from $\$ 450$ in 1929 to $\$ 50$ in 1932 . The securities of other holding company systems did likewise. ${ }^{5}$ Insull lost his entire fortune estimated at about $\$ 100,000,000.00$; he surrendered his life insurance and his country estate valued at $\$ 3,400,000.00$. He had more than fulfilled the admonition of Edison. "I have gone from the bottom to the top, and now to the bottom again," he is reported to have said in $1932 .{ }^{6}$ Over IOO,OOO stockholders of his companies lost large sums, the total loss being estimated as high as $\$ 4,000,000,000.00$. $^{7}$ The Insull debacle impressed upon the public the need for some sort of regulation to prevent the recurrence of such financial slaughter and was thus the prime causative factor in the enactment of the Public Utility Holding Company Act of I 935 .

Insull's predecessor in public utility holding company infamy was Wilbur B. Foshay, who built his empire of utility and other odds and ends in thirteen states, Canada, Alaska,

- Cities Service Company stock fell from $\$ 68.12$ to $\$ 1.25$; Electric Bond \& Share Company stock went from $\$ 189$ to $\$ 5$. Ramsay, op. cit., note 2,81 .

Thompson, Carl D., Confessions of the Power Trust, 247-248 (1932).

${ }^{\top} I d$. at 248 . 
and Central America. It sank ingloriously into receivership on November I, 1929, at the beginning of the stock market panic, and left as relics a 32-story tower in Minneapolis designed after the Washington Monument and the reassuring slogan, "All your money-All the time-On time." The loss to the public was approximately $\$ 29,000,000.00$. The Foshay technique involved the writing up or "appreciation" of assets with a corresponding credit to surplus account at times when such account would otherwise have shown a deficit, and the increase in the surplus account would then be credited to income at times when the net income would otherwise have shown a loss. Monthly dividends were paid almost continuously during the 12 year life of the business. The necessary cash to pay the dividends was derived from successive sales of securities by the company. ${ }^{8}$ Foshay was convicted and imprisoned upon mail fraud charges. Although his manipulations through the medium of the public utility holding company were lesser in magnitude than those of others, the publicity attendant upon his collapse added fuel to the fire.

The crown prince of corporate jazz was Howard C. Hopson of the Associated Gas \& Electric Company system. He succeeded and exceeded both Foshay and Insull in holding company legerdemain. Proof of his superiority in this field lies in the fact that his companies, although on the brink of insolvency (if not actually over the line) beginning in I93 I, were not placed in bankruptcy until I 940 by the Securities and Exchange Commission. As early as 1927 the capital structure of A. G. \& E. was characterized as "a financial nightmare." Its securities were held by a quarter-million investors, and its

${ }^{8}$ Ramsay, op. cit., supra, note 2, 80; Thompson, op. cit., supra, note 6, 267.

'Ripley, Wm. Z., Main Street and Wall Street, 322-323 (1927). Also see Bonbright, J. C., and Means, Gardiner C., The Holding ComPANY (I932). 
" $A$ " stock which sold for $\$ 72.62$ at the market peak went to $62 \phi$ in $193^{2} .^{10}$ Hopson assembled the Associated system from a $\$ 7,000,000.00$ base in 1922 to a $\$ 1,000,000,000.00$ pyramid in 1940. There was at least $\$ 400,000,000.00$ of water in the latter figure. He had created or acquired holding, subholding, electric, gas, water, ice, streetcar, bus, real estate management service and investment companies under 1,800 different names in 26 states, two Canadian provinces, and the Philippine Islands. The securities of the system included nonvoting common stock, debentures convertible into stock at the option of either the holder or the company, preferred stocks labeled as bonds, and certificates that paid different interest under different contingencies and were convertible into practically anything the holder wanted. Hopson, a lawyer, C.P.A., and one-time key man in the Public Service Commission of New York, was not interested in money for its own sake, but he became more and more fascinated by the power that went with control over money. He and John I. Mange acquired the Associated System in I922 by a complicated set of maneuvers whereby they emerged with $100 \%$ control of Associated Gas and Electric Company plus a cash profit to themselves of $\$ 218,000.00^{11}$ Hopson originally drew no salaries from the Associated companies but derived his income by means of sixteen service companies operated by him. His method of operation has been described in the following manner:

"By the utility promotion standards of the times, there was nothing particularly illegal and few things that were novel in Hopson's corporate and financial pyramiding during the twenties. Hopson simply carried to an extreme holding-company practices that have since been

\footnotetext{
${ }^{10}$ Ramsay, op. cit., supra, note 2,81 .

"'Through the Wringer with A.G. \& E.," Fortune MAGAZINE, 165, 202 (December, 1945 ).
} 
condemned. Other promoters paid too much money for operating properties, wrote them up on the books, and issued excessive amounts of securities on the strength of the write-ups; Hopson paid more than even his most extravagant competitors were willing to pay, and made his system top-heavy with securities that were just a little more freakish than anybody else's. Other systems occasionally juggled their operating companies around among subholding companies; Hopson kept his in perpetual motion. Others high-pressured employees and customers into buying their stocks and bonds; Hopson's 'customer ownership' campaigns were the biggest and most flamboyant ever staged. Other holding companies relied on service charges to pump operating-company earnings up to the top of the system; Hopson siphoned off his service-company profits into his personal bank account....

* * *

"Actually, it was Hopson's extracurricular activities as the self-appointed spokesman for unregulated holding-company enterprise that caused his downfall. As any newspaper reader of the mid-thirties knows, Hopson was probably the main reason for the passage of the Utility Holding Company Act and its so-called 'death sentence' provisions. The horrific examples of Associated's extravagant financing, write-ups, and service-company abuses-plus Associated's inept lobbying activities (which included a flood of telegrams to Congress from the graveyard), plus Hopson's dodging of House and Senate subpoenas-undoubtedly supplied the votes to pass the Wheeler-Rayburn bill."

The most ardent and effective supporter of regulatory legislation for public utility holding companies was President Franklin D. Roosevelt. As Governor of New York his prin-

${ }^{12} I d$. at 202,205 , and 216. 
cipal achievement was a partial settlement of the hydroelectric question on the basis of public development of the St. Lawrence waterpower. Part of his political philosophy was the theory that the masses of economic power represented by the utility holding companies should be broken up and that for regulation to have a chance the power of the regulatory body should be at least equal to that of the institution to be regulated. ${ }^{13}$ Undoubtedly at his insistence, the 1932 platform of the national Democratic Party advocated regulation to the full extent of federal power of holding companies which sold securities in interstate commerce. ${ }^{14}$ The vote in favor of the Wheeler-Rayburn bill, which became the Public Utility Holding Company Act of 1935, was also inspired to a considerable extent by the blind adherence of many Congressmen to the wishes of the president. ${ }^{15}$

Another important factor giving rise to the enactment of the holding company legislation was the investigation of the subject by the Federal Trade Commission begun in 1928 .

The Commission had made a prior investigation covering the situation as it existed, at the close of 1924 . In this earlier investigation the Commission was instructed to inquire particularly into the extent of the control of the utility industry by the General Electric Company. The report of the Commission upon that matter, submitted in 1927, stated that neither General Electric Company nor any other company had secured or was securing a substantial monopoly in the electric industry. ${ }^{16}$ Although General Electric did control the largest utility interest in 1924, it promptly disposed of Electric Bond \& Share Company and thereby removed itself as a monopolistic threat in the utility field. The investigation be-

\footnotetext{
${ }^{22}$ Ramsay, op. cit., supra, note $2,266$.

1479 CONG. RECORD I0836 (I 935 ).

1579 CoNG. ReCORD 10657 ( I 935 ).

16 "Electric Power Industry, Control of Power Companies," Doc. No. 213 , 69th Cong., 2d Sess., p. 5o.
} 
gun in 1928 was a different matter. It was not completed until 1937, although the serious import of the so-called "power trust" was evident from preliminary reports as early as 1932. ${ }^{17}$ The Federal Trade Commission examined 18 top holding companies, 42 subholding companies, and 91 operating companies in the electric and gas industry. The revelations of this survey formed the basis of the indictments of the electric and gas holding company systems set forth at length in Section $\mathrm{r}(\mathrm{b})$ of the Public Utility Holding Company Act of $1935,{ }^{18}$ hereinafter often referred to as the "Act." The early disclosures of the Federal Trade Commission study also induced several states, notably New York, Massachusetts, and Pennsylvania, to undertake investigations of holding companies and their relation to public utility regulation. ${ }^{19}$

Warning notes were also sounded by some of the leading economists of the nation. Probably the first of these was Professor William Z. Ripley of Harvard University in his work entitled Main Street and Wall Street. ${ }^{20} \mathrm{He}$ noted, inter alia, that the country was faced with a development precisely parallel to that through which it had passed with respect to railroads, telegraphs, and telephones, and he posed the problem of ascertaining whether or not electric public utilities belonged in the same class and should be subjected to the same administrative control. There were other economists who were alarmed at the abuses of the holding company device, some of the more notable ones being Arthur Stone Dewing, ${ }^{21}$

"Thompson, op. cit., supra, note 6.

49 Stat. 803 (1935), 15 U.S.C.A., Sec. 79a. Pursuant to H. Res. No. 59, 72nd Cong., ist Sess. (1932), and H.J. Res. No. 572, 72nd Cong., $2 \mathrm{~d}$ Sess. (1 933 ), the House Committee on Interstate and Foreign Commerce published a six volume study entitled "Relation of Holding Companies to Operating Companies in Power and Gas Affecting Control" (1932-1933).

${ }_{10}$ Buchanan, Norman S., "The Public Utility Holding Company Problem," 25 Calif. L.R. 517 (1937). Cf. comment, "Section i1 (b) of the Holding Company Act: Fifteen Years in Retrospect," 59 YALE L.J. 1088 (1950).

${ }^{20}$ Op. cit., supra, note 9 .

"Author of The Financial Policy of Corporations (3rd Ed., 1934). 
William A. Prendergast, ${ }^{22}$ and J. C. Bonbright and Gardiner C. Means. ${ }^{23}$ Their roles in bringing about the holding company legislation, although indirect, were substantial.

Still another factor giving rise to this legislation was the occurrence of the great depression beginning in 1929. It is true that some of the holding company systems, such as that of W. B. Foshay, collapsed before the depression really began, and that others, such as that of Howard C. Hopson, weathered the depression only to fail at a later date. It is also true that most of the systems survived the storm intact despite great declines in the market values of their securities. Furthermore, it proved to be generally true that operating utilities, as distinguished from utility holding companies, survived the crash in better shape than most other types of business. However, the depression served to remove the gilt and the glitter from the holding company device and to reveal it in its true light. The success of the methods employed by Insull and others in the 1920's depended upon a continual increase in the values and earnings of utility properties in order ultimately to justify the high prices originally paid for such properties. Rapid and continuous increases were the order of the day in the twenties, but the cycle was completely reversed at the beginning of the thirties. The functions of holding companies could then be studied in the cold light of adverse conditions and, when weighed in the balance, they were found wanting.

And, finally, in this brief review of events and personalities leading up to the enactment of the Public Utility Holding Company Act of 1935, mention should be made of the report of the National Power Policy Committee on Public Utility Holding Companies. ${ }^{24}$ This committee was appointed by

${ }^{22}$ Author of Public Utilities and the People (1933).

${ }^{23}$ Authors of THE Holding Company (1932).

${ }^{24}$ Public Utility Act of 1935, Senate Report No. 621, 74th Cong;, 1st Sess., 55-60. 
President Roosevelt in 1934 and it was composed of Harold L. Ickes, Secretary of the Interior and chairman, Frank R. McNinch, Elwood Mead, T. W. Norcross, Morris L. Cooke, Robert E. Healey, David E. Lilienthal, and Edward M. Markham. All of these men were government officials concerned with power problems. The conclusions of the committee were, briefly, that legislation should be forthcoming eliminating within a reasonable time the holding company where it served no useful and necessary purpose, placing federal control of the holding company problem in the hands of an administrative commission, encouraging geographically and economically related systems, prohibiting holding companies from engaging in nonutility and speculative ventures and other undesirable practices, and requiring periodic and uniform financial reports. The report of the committee was transmitted to Congress on March I2, 1935, by the President along with his message urging favorable action upon the holding company bill then pending. It therefore served as the keynote for the proponents of this legislation.

\section{Advantages and Disadvantages of Public Utility Holding Companies}

The earliest approach to the modern holding company was the predecessor of United Gas Improvement Company. ${ }^{25}$ This company was incorporated in Pennsylvania in I 882 for the purpose of introducing water gas in the manufactured gas industry. The older method of manufacturing illuminating gas from the distillation of coal was so difficult to displace that the company at first leased gas works in various parts of the country and later acquired their stocks. This acquisition of control of disconnected local gas works, beginning in I 884, was perhaps the first attempt to bring under one management

${ }^{23}$ Dewing, Arthur Stone, The Financial Policy of Corporations, 858 ff. (3rd Ed., 1934). 
a number of independent and geographically separated public utilities. In the I890's imitators appeared on the horizon in the form of The North American Company, the United Electric Securities Company, and the Philadelphia Company, and, in 1900 , American Light \& Traction Company was formed. From that time until World War I many varieties of holding companies were organized by banking and engineering firms. A striking phenomenon of the twenties, however, was the great increase in new utility combinations and in substantial enlargements of existing systems. ${ }^{26}$ The formation of farflung territorial combinations became one of the most popular corporate activities of the decade. The feeling was prevalent that the leaders of the electrical industry intended eventually to form a company in the power field similar to American Telephone \& Telegraph Company in the telephone field. ${ }^{27}$ The era of "superpower" was at hand, and the vehicle used to promote superpower was the holding company.

What, then, were the advantages and the disadvantages of that vehicle from a general point of view? The advantages were roughly four in number, as set forth below.

I. The basic economic advantage of holding companies, according to the opponents of the holding company bill, was the diversification provided by such companies for investors, both as to geographical location and as to variation of activities. $^{28}$

2. Small utility systems were thereby provided with the finest engineering, administrative, legal, accounting, auditing, purchasing, and other services which would otherwise have been available only to large systems.

${ }^{20}$ Ripley, op. cit., supra, note 9, 280 .

${ }^{27}$ Thompson, op. cit., supra, note $6,3 \mathrm{r}$.

${ }^{23}$ Willkie, Wendell L., "The Future of the Holding Company," I I Journal of LAND AND PUblic Utility Economics 234 (1935); H. Hearings on H. R. 5423, 74th Cong., Ist Sess. (1935), p. 2175 ; S. Hearings on S. 1725 , 74th Cong., ist Sess. (1935), p. 311. 
3. Financial strength was given small systems by virtue of the facilities of the parent for providing capital and selling securities upon advantageous terms.

4. The holding company was in a better position to handle matters of public relations and regulation than the individual small operating companies.

The reply of the proponents of the bill to the first argument in favor of holding companies was that (a) in practically no instance could it be proved that diversification of investment was an original corporate purpose, the argument being merely a rationalization in retrospect; (b) diversification should be provided either by the individual investor or by an investment company, not by a utility holding company; (c) considerable diversity of risk could be obtained by an integrated system concentrated in one large area; (d) in most of the existing systems the risk was very unevenly distributed geographically; and (e) the so-called "diversified" systems suffered the largest losses during the depression. ${ }^{29}$ The answers to the second and third arguments were that the advantages of a centralized management organization which supervised at a distance the operations of a chain of local properties became less and less as the size of each local unit grew greater, and that when the operating companies reached a certain size they became able to afford the best talent without holding company assistance and to finance their own operations. At some point, which was being approached by many operating companies, the disadvantages of absentee management from Wall Street or LaSalle Street would outweigh the advantages of the centralized organization. The answer to the last argument was that although the holding companies had been a great factor in the development of efficient electrical systems in this country and although their

${ }^{29}$ Cf., Douglas, Wm. O., "Scatteration v. Integration of Public Utility Systems," 24 A. B. J. 800 (1938). 
freedom from regulation during the pioneer days of formation was a substantial advantage, and permitted their rapid growth, the pioneering days were over and the time had come when a lower premium should be paid for speed of development and a much higher premium for carefully evolved plans of coordination dictated in the interests of engineering, efficiency and of the requirements of the communities concerned, rather than primarily in the interest of large profits for utility financiers. ${ }^{30}$

The justification of the holding company, of course, lies in its use and not in its abuse. An impartial study of both holding company systems and independent systems would probably have revealed that a substantial number of holding company systems were better managed than the vast majority of independent operating companies. Also, there were system companies which had much poorer management than the average independent company. The antagonism between the proponents and the opponents of the holding company bill prevented an unbiased consideration of the matter, however. ${ }^{31}$

The weaknesses and defects charged against the utility

${ }^{*}$ Bonbright and Means, op. cit., supra, note 23, 22 I-222.

"Dewing, op. cit., supra, note 25,883-884. For such a study at a later date, see Waterman, Merwin H., "Economic Implications of Public Utility Holding Company Operations," 9 Michigan Business Studies, No. 5 (1941). Prof. Waterman reached the following conclusions: ( 1 ) There was no evidence that independent utilities were better than subsidiaries of public utility holding companies as to (a) costs of electricity to consumers, (b) economy in management, (c) soundness of financial management, or (d) protection of operating company investors; (2) residential electricity customers found benefits related to increasing size as measured by the weighted average typical electricity bills which decreased steadily as the size of the operating company increased and also as the size of the holding company system increased; (3) mere distance of operating companies from the main office of their respective holding companies in and of itself did not tend to be related in any way to the character or quality of the protection afforded to the investors in the securities of such operating company, nor did this variable show any connection with any of the other objectives of the Act; and (4) the indications were that state regulation of holding company subsidiaries was, at the time of the study, as efficient and effective as state regulation of independent utilities. 
holding company device were much more numerous. Those listed below were the most glaring at the time the holding company bill was under consideration in Congress.

I. The corporate structures of many systems were unduly complex and unwieldy with excessive layers of holding companies stacked upon a few operating companies; and not only were the corporate structures of such systems complex in a static sort of way, they were often complex dynamically. That is, as in the case of Associated Gas \& Electric Company, the corporate structures were being rapidly changed from day to day.

2. By the use of the holding company device a relatively small investment could result in control of properties with values many times greater than the investment of the controlling party. This was the pyramiding process which disfranchised the mass of the investors in many systems.

3. Inflation of the capital account or even the earnings account by write-ups, better known as stock watering, was prevalent. ${ }^{32}$ Other types of financial manipulation too numerous to mention were also indulged by the holding companies.

4. Upstream loans from subsidiaries to parent companies were frequent.

5. The obfuscation of accounts and accounting records was a common practice to the utter confusion of regulatory authorities, investors, consumers, and the public.

6. Many holding company systems were guilty of "scatteration." Their operating properties were not grouped in economically sound nor geographically contiguous units, but were spread all over the map in defiance of all principles of engineering efficiency.

27 The reports of the Federal Trade Commission indicated that this practice was commonly employed by systems both large and small, and resulted in tremendous inflations of property values. Thompson, op. cit., supra, note 6 , 136-137. 
7. Most of the systems owned subsidiaries or operated properties engaged in nonutility and speculative enterprises in no way connected with their utility operations. ${ }^{33}$

8. By the use of a holding company or holding companies a system could render ineffective all state and local regulation. The large systems were superior to local politics. ${ }^{34}$

9. Local utility operations were controlled, managed and directed from a home office often far distant. For example, absentee management of Engineers Public Service Company in New York City controlled operating properties in the State of Washington 3, roo miles away. ${ }^{35}$

IO. Some of the systems were dominated by engineering or service companies which extracted exorbitant fees for their assistance. Others were controlled by investment bankers who were more interested in the sales of securities than in the proper conduct of the utility business.

II. Transactions were often entered into among parent companies and their subsidiaries and affiliates without arm's length bargaining, resulting in detriment to one or more of the parties, usually the operating company.

I2. Excessive prices were paid for additional properties on a number of occasions which received wide publicity. Both Insull and Hopson were notorious in this respect.

The foregoing disadvantages of the utility holding company form and method of operation present the state of affairs

3s The investigations of the Federal Trade Commission showed that utility holding companies also controlled and operated such diverse businesses as paper mills, spinning mills, fertilizer companies, chemical production, banking, insurance, bus lines, ice plants, water works, real estate promotions, and coal mines. Thompson, op. cit., supra, note 6, 47-48. The evils of such unrelated operations were demonstrated by the failure of The Middle West Utilities Company, discussed by Dewing, op. cit., supra, note 25,877 , footnote $v$.

${ }^{\text {s4 }}$ See, e.g., H. Hearings on H.R. 5423, 74th Cong., Ist Sess. (I935), p. t693.

${ }^{25}$ See "Charts 'Showing Location of Operating Electric and/or Gas Subsidiaries of Registered Public Utility Holding Companies, 1939," a report of the Public Utilities Division, Securities \& Exchange Commission. 
in 1935 as seen by the proponents of the holding company bill. Not all of these alleged evils existed in every large system and some of them were perhaps unobjectionable from many points of view. The President, however, expressed his views in this manner:

“... It is time to make an effort to reverse that process of the concentration of power which has made most American citizens, once traditionally independent owners of their own businesses, helplessly dependent for their daily bread upon the favor of a very few, who, by devices such as holding companies, have taken for themselves unwarranted economic power. I am against private socialism of concentrated private power as thoroughly as I am against government socialism. The one is equally as dangerous as the other; and destruction of private socialism is utterly essential to avoid governmental socialism."

\section{Legislative History of the Public Utility Holding}

\section{Company Act of 1935}

The original provisions of the holding company bill, introduced in the House of Representatives by Sam Rayburn and in the Senate by Burton K. Wheeler on February 6, I935, were written by two young lawyers, Thomas G. Corcoran and Benjamin V. Cohen, both graduates of Harvard

${ }^{96}$ Message of President Franklin D. Roosevelt to Congress, 79 Cong. RECORD 3425 and 3469 (March 12, 1935). Some, perhaps, considered the President's allusion to governmental socialism an unfortunate comparison. Another advocate of the bill expressed his sentiments in more colorful language: "The stables of Augeus, left unclean for 30 years, were not as foul, as corrupted and contaminated as holding company methods, whose contagion of crookedness jeopardized the welfare of an entire nation of $126,000,000$ people. A cleansing river torrent is needed to wash away the unfathomable muck of wide-spreading financial frauds that threaten our Republic and its democratic processes, just as the Augean stables were cleaned by a river, purposely changed in its course, as the fable relates." S. Hearings on S. I 725 , 74th Cong., ist Sess. (1935), p. 1079. 
Law School and proteges of Felix Frankfurter. ${ }^{37}$ It is probable that the revisions and amendments to the bill were also drawn by Corcoran and Cohen, although this is not shown in the record. Corcoran was counsel for the Reconstruction Finance Corporation and Cohen worked for Public Works Administration and the National Power Policy Committee. During the pendency of the bill, however, it appeared that they devoted most of their time to supervising its progress through the legislative channels. ${ }^{38}$

The storm of protests against the holding company bill was centered around the provisions of its Section I I, popularly referred to as the "death sentence" clause. It was so labeled because it called for the elimination of holding company systems which were not "geographically and economically integrated," and also provided for the removal of unnecessary tiers of holding companies. No definition of geographical and economic integration was given in the bill, and there was a great deal of confusion as to its meaning. Witnesses before both the House and Senate committee hearings evidenced an inability to reach a common understanding of the term as applied to the electric, manufactured gas, and natural gas utilities included within the scope of the bill. $^{39}$ The only logical conclusion to be drawn was that an almost unlimited discretion would be given to the Securities and Exchange Commission to determine whether geographical and economic integration existed in each particular case. This, of course, was contrary to the principles laid down by the Supreme Court of the United States with reference to

${ }^{32} 79$ CoNG. ReCORd Io529 (1935); Ramsay, op. cit., supra, note 2, 269272.

79 CoNG. Record 10660 and 12273 (1935); Senate Hearings on S. I 725 , 74th Cong., ist Sess. (1935), p. 204.

${ }^{38}$ House Hearings on H.R. 5423, 74th Cong., Ist Sess. (1935), pages 802, 1917-1918, and 2225; Senate Hearings on S. 1725, 74th Cong., Ist Sess. (1935), pages 323 and 935 . 
the National Recovery Administration and would have been unconstitutional..$^{40}$ The object of the sponsors of the bill was to reform scattered and loosely knit systems such as Middle West Utilities Company, Associated Gas \& Electric Company, and Electric Bond \& Share Company into unified operations like those of Consolidated Edison of New York, Detroit Edison of Detroit, or Commonwealth Edison of Chicago. ${ }^{11}$ Their immediate problem was concerned with the wording of this objective in the bill so as to accomplish the desired purpose.

The hearings held by the Committee on Interstate and Foreign Commerce of the House of Representatives on the holding company bill were begun on February 19 and concluded on April I 5, 1935. The hearings on the bill held by the Senate Committee on Interstate Commerce extended from April I6 to April 29, 1935. The original bill was replaced by a substitute bill in the House committee, and as amended, was reported favorably. ${ }^{42}$ The House bill contained a definition of "integrated public utility system" in substantially the same form as finally enacted. Section I I, the death sentence, had been drastically modified to give the Commission authority to require each holding company system to confine its operations to one integrated public utility system, with the exception that if the Commission found that such a limitation was not necessary in the public interest, it was to require the limitation of the operations of the holding company system to such number of integrated utility systems as it found could be included in the holding company system consistently with the public interest. Further, the Commission was authorized to require divestment of nonutility properties

${ }^{* 0}$ Schechter Poultry Corp. v. U.S., 295 U. S. 495 (1935).

${ }^{41}$ Ramsay, op. cit., supra, note $2,28 \mathrm{I}-282$.

${ }^{42}$ Public Utility Act of 1935, H. R. Report No. 1318, 74th Cong., Ist Sess. (1935). 
only where it found that the retention thereof would be inconsistent with the public interest. And the Commission could not require divestment of interests outside of the United States. A minority of the House committee felt that the bill as reported would fatalistically condone and perpetuate the holding company system and that Section I I had been emasculated so as to defeat completely the President's program. ${ }^{43}$ The bill was adopted by the House as reported by a vote of 323 to 81.4

In the Senate committee, also, the original bill was replaced by a substitute bill. This latter bill was reported favorably without amendment. ${ }^{45}$ The bill passed the Senate by a vote of 56 to. 32 . $^{46}$ The Senate bill did not include a definition of "integrated public utility system." It required each holding company to limit its operations to a single geographically and economically integrated public utility system and to such business as was reasonably incidental or economically necessary or appropriate to the operations of such system. The Senate thus adhered much more closely to the recommendations of the President and the National Power Policy Committee than the House. Senator Wheeler made the following pertinent remarks concerning the two bills:

". . . The only difference between the House bill and the Senate bill is that the House bill leaves the 'death sentence' up to the Commission. The Commission could say that the Electric Bond \& Share Co. should go out of business because it was against the public interest; they could say that the United Corporation should stay in

${ }^{43}$ Id. at $44-45$.

79 CONG. RECORD 10639 (1935).

${ }^{45}$ Public Utility Act of 1935, Senate Report No. 621, 74th Cong., Ist Sess. (1935). Also see the minority report of the Senate Committee, Senate Report No. 621, Part 2, 74th Cong., ist Sess. (1935), which fulminated against the bill as approved by the majority but offered no concrete suggestions for improvement.

${ }_{79}$ CONG. RECORD 9065 (1935). 
business because it was in the public interest; they could say that the Insull Co. was in the public interest and that the Commonwealth \& Southern was against the public interest. I say to the Senator that if ever there was an unconstitutional discretion placed in the hands of a commission, that, in my opinion, is a delegation of power which is unconstitutional. ${ }^{47}$

The two bills were referred to a joint conference committee of the House and the Senate, and by virtue of a compromise attributed to Senator Alben W. Barkley the present Act was evolved. ${ }^{48}$ The Senate bill was considerably diluted, principally by the "ABC" clauses permitting the retention of more than one integrated utility system, and the "public interest" phrase in the House bill was replaced by more precise standards. Second degree holding companies were permitted in the compromise bill, whereas the Senate bill had allowed only one layer of holding companies. The Conference Report was adopted on August 24, I935, by the House by a vote of 222 to I 12 and was adopted on a voice vote by the Senate. ${ }^{49}$ The bill was signed by the President and became law on August 26, I935. ${ }^{50}$

\section{Constitutionality of the Act}

The unfavorable decisions by the Supreme Court of the United States as to the constitutionality of other New Deal legislation, rendered contemporaneously with the passage of

79 CONG. RECORD I 8442 (1935).

49 CONG. RECORD 14600 and 14620 (1935).

49 CONG. RECORD 14473 and 14626 (1935).

so The foregoing discussion has been with reference to Title I of the Public Utility Holding Company Act of I 935. This Act also included Title II, which amended the Federal Water Power Act so as to encourage voluntary interconnection and coordination of facilities for the generation, transmission, and sale of electric energy under the jurisdiction of the Federal Power Commission. I 6 U.S.C.A., Sec. $824 \mathrm{a}$ (a). The "voluntary" feature of Title II rendered it ineffective. 
the Public Utility Holding Company Act of 1935 , caused the majority of holding companies to refrain from complying with the registration provisions of the Act. On September 28, 1935, the Securities and Exchange Commission, hereinafter referred to as the "Commission," published a speech by its Chairman, James M. Landis, in which he exhorted the industry to cooperate with the Commission in solving its various problems under the Act, promising to recognize and respect the constitutional rights of each party. ${ }^{51}$ The Commission received a set-back in an early decision which held that all of the provisions of the Act, and particularly the registration provisions, were unconstitutional. ${ }^{52}$ On appeal the Circuit Court of Appeals for the 4th Circuit held that the Act did not apply to the holding company involved, since it was not engaged in interstate commerce, but rejected the portion of the decree of the lower court holding that the Act was unconstitutional in its entirety. ${ }^{53}$ The registration provisions of the Act were subsequently upheld by the Supreme Court on March 28, 1938. ${ }^{54}$ On April 5, 1938, the Commission announced that holding companies controlling approximately $98 \%$ of the total book assets estimated to be subject to the Act had been duly registered.

Section II (b) of the Act required the Commussion to commence its integration and simplification proceedings as soon as practicable after January I, I938. The Commission, advancing in cautious fashion, sponsored the formation of a committee of utility holding company executives to cooperate

${ }^{2}$ Release No. 3 (Sept. 28, 1935); Release No. 22 (Nov. 22, 1935). All "releases" cited herein are those issued by the Securities \& Exchange Commission under the Public Utility Holding Company Act of 1935.

${ }^{5}$ In Re American States Public Service Co., 12 F. Supp. 667 (D. C. Md., I 935).

Burco, Inc. v. Whitworth, 8I F. (2d) 721 (C.C.A., 4th Cir., 1936), cert. denied, 297 U. S. 724 (1936).

${ }^{3}$ Electric Bond \& Share Co. v. Securities \& Exchange Commission, $3 \circ 3$ U. S. 419 . 
with the Commission in achieving compliance with Section I I (b). This committee was created on May 5, I938. The new Chairman of the Commission, William O. Douglas, addressed the annual meeting of the American Bar Association on July 26 , 1938, issuing a warning that the Commission was determined to get ahead with its assignment. ${ }^{55} \mathrm{On}$ August 4, I938, the Commission made public a letter which it had sent the previous day to the heads of 66 holding companies requesting them to submit to the Commission integration and simplification suggestions, plans, and programs under the Act, even though tentative, not later than December I, I938. ${ }^{56}$ By the deadline date the Commission had received responses from 64 of the 66 companies contacted.

Speculation as to the constitutionality of Section I I (b) continued to be a lively issue, giving rise to considerable legal comment. ${ }^{57}$ The case selected to test the constitutionality of Section I I (b) (I) was that of The North American Company. ${ }^{58}$ The North American decision was a comprehensive treatment of the integration problems of a large system and therefore constituted the proper basis for a review of the constitutionality of the integration provisions of the Act. The Circuit Court of Appeals for the Second Circuit held on January 12, I 943, in the North American case that Section I I (b)

* Douglas, Wm. O., "Scatteration v. Integration of Public Utility Systems," 24 A.B.J. 800 (1938). Cf., Jome, H. L., "The New Schoolmaster in Finance," $40 \mathrm{MICH}$. L. R. 625 (1942).

${ }^{6}$ Release No. 1192 (Aug. 4, I 938 ).

"Hamlin, Scoville, "Is the Utility 'Death Sentence' Unconstitutional?" 2 Corporate Reorganizations 95 (r935); note entitled "The Constitutionality of the Public Utility Holding Company Act of 1935," 23 VA. L. R. 678 (1937); Lesser, L. S., "Constitutional Powers of the Securities \& Exchange Commission over Public Utility Holding Companies," 8 Geo. Washington L. R. II 8 (1940); and Davison, Jas. F., "Death Sentences for Public Utility Holding Companies," 8 Geo. Washington L. R. I 148 (1940).

st The North American Company, Ix S.E.C. I94 (1942), and The North American Company, 11 S.E.C. 715 (1942). The Commission, in accordance with its fixed policy, did not undertake to pass upon the constitutionality of the Act. 
(I) was constitutional. ${ }^{58}$ The contentions of the company that the ownership of securities did not constitute engaging in interstate commerce and that the requirements of Section II (b) (I) amounted to the taking of property without due process of law in violation of the prohibition of the Fifth Amendment to the Constitution were overruled.

A writ of certiorari was granted by the Supreme Court in this case early in $1943 .{ }^{60}$ On the day set for argument Chief Justice Harlan Stone disqualified himself because Charles Evans Hughes, Jr., was present to argue in behalf of North American. Justices Frank Murphy and Robert Jackson disqualified themselves as former Attorneys General of the United States, and Justice William O. Douglas disqualified himself since he had formerly been Chairman of the Securities and Exchange Commission. The withdrawal of four justices prevented the court from having a legal quorum of six justices and the case accordingly was postponed. ${ }^{61}$ In May, I945, Justice Stone decided that he was eligible to hear the case and argument was rescheduled for the following October. In July Justice Owen Roberts resigned and the court was obliged to postpone argument once more. However, Senator Harold Burton was appointed to fill the vacancy on the court created by the resignation of Justice Roberts and he considered that his former connections with two utility systems were too remote to disqualify him from considering the North American case. Accordingly, on November I5, 1945, after a delay of two years and nine months, arguments on the constitutionality of the "death sentence" provisions of the Act were presented to the Supreme Court. By this time, of course, considerable progress had been made towards the

${ }^{39}$ The North American Company v. Securities \& Exchange Commission, 133 F. (2d) I 48 (C.C.A., 2d Cir., I 943 ).

${ }^{\infty}$ North American Company v. Securities \& Exchange Commission, $3^{18}$ U. S. 750 (1943).

"is The Wall Street Journal, October 29, 1945. 
integration of numerous holding company systems and it was impossible to undo the changes already made. However, in view of the previous court decisions involving the Act and the revisions in the personnel of the Supreme Court effected by President Roosevelt, an ultimate holding of constitutionality was practically a foregone conclusion.

The decision of the Supreme Court in The North American Company case was finally rendered on April I, 1946, almost four years after the original order of the Commission. ${ }^{62}$ It was limited in its scope to a consideration of the constitutionality of Section I I(b) (I) of the Act. The first contention of North American was that its sole business was that of acquiring and holding for investment purposes stocks and other securities of its subsidiaries, and that therefore its business was essentially intrastate only. The Supreme Court found, however, that North American was more than a mere investor in its subsidiaries and that its influence and domination permeated the entire system. The mails and the instrumentalities of interstate commerce were held to be vital to the functioning of this system, and the acts of the subsidiaries were deemed to be acts of North American as well. The court felt that Congress was within its jurisdiction in imposing relevant conditions and requirements such as those contained in Section II(b)(I) upon parties using the channels of interstate commerce in order that such channels would not become the means of promoting or spreading evil, whether of an economic nature, as in this case, or of a physical or moral nature.

North American also attacked Section I I(b)(I) on the

a The North American Company v. Securities \& Exchange Commission, 327 U. S. 686. There was no dissent. The opinion was written by Justice Frank Murphy, and the other justices participating in the decision were Chief Justice Harlan F. Stone, Hugo L. Black, Felix Frankfurter, Wiley Rutledge and Harold H. Burton. Justices Reed, Douglas, and Jackson took no part in this case. 
ground that it violated the due process clause of the Fifth Amendment to the Constitution. The court held that the rights of the holding company to maintain the status quo were outweighed by the actual and potential damage to the public, the investors, and consumers resulting from the use made of pooled investments. Furthermore, the court concluded, the Act does not contemplate or require the dumping or forced liquidation of securities on the market for inadequate considerations, and consequently the question as to whether there had been a destruction of the values of such property without just compensation could not arise.

Finally, North American claimed that it was guilty of none of the evils specified in Section I (b) of the Act and that it should be allowed to prove that fact. The court held that Congress had the power to legislate generally, unlimited by proof of the existence of the evils in each particular situation, and that Section I I (b) ( I) was not designed to punish past offenders but to remove what Congress considered to be potential if not actual sources of evil. The constitutionality of Section Ir(b) ( I ) was accordingly sustained by the Supreme Court on all counts and the decisions of the Commission and the Circuit Court of Appeals were affirmed. The legal arguments which sounded so cogent to leaders in the industry in I 935 did not shine so brightly a decade later. The Supreme Court decision confirmed their growing suspicion that the Act was here to stay. 


\section{Chapter 2}

\section{Definition of Integration}

\section{THE Public Utility Holding Company Act of I935 defines an "integrated public-utility system" in this 1 manner: "(A) As applied to electric utility companies,}

a system consisting of one or more units of generating plants and/or transmission lines and/or distributing facilities, whose utility assets, whether owned by one or more electric utility companies, are physically interconnected or capable of physical interconnection and which under normal conditions may be economically operated as a single interconnected and coordinated system confined in its operations to a single area or region, in one or more States, not so large as to impair (considering the state of the art and the area or region affected) the advantages of localized management, efficient operation, and the effectiveness of regulation; and (B) As applied to gas utility companies, a system consisting of one or more gas utility companies which are so located and related that substantial economies may be effectuated by being operated as a single coordinated system confined in its operations to a single area or region, in one or more States, not so large as to impair (considering the state of the art and the area or region affected) the advantages of localized management, efficient operation, and the effectiveness of regulation: Provided, That gas utility companies deriving natural gas from a common source of supply may be deemed to be included in a single area or region." ${ }^{\text {"s }}$

One of the earliest problems which arose under this definition of integrated systems was whether electric utility prop-

Section 2(a) (29) of the Public Utility Holding Company Act of 1935. All references herein to the "Act" mean the Public Utility Holding Company Act of 1935,49 Stat. 803 (1 935), 15 U.S.C.A., Sec. 79. 
erties and gas utility properties could be combined in one integrated system. In the American Water Works \& Electric Company case it appeared that electric utility operations were carried on by the system in Pennsylvania, West Virginia, Ohio, Maryland, and Virginia, covering a territory approximately 300 miles north and south, and 300 miles east and west. ${ }^{64}$ The electric properties were physically interconnected for the most part, and those not so connected were capable of physical interconnection, and further interconnections were being made. Gas utility operations were carried on by the system in West Virginia, Pennsylvania, and Maryland, part of the territories served by the system with electricity. The gas operations were small compared to the electric operations. There was evidence to the effect that substantial economies resulted from the joint use of personnel and facilities by the electric and gas operations. This combination of electric and gas facilities was held to be one integrated utility system. The Commission reasoned as follows:

"No specific mention is made in the definition of an integrated public-utility system concerning a combined gas and electric system. We believe, however, that it is proper to regard such a combined property as a single integrated system, provided that all of the electric properties are integrated and all of the properties, both gas and electric, are in fairly close geographic proximity and are so related that substantial economies may be effectuated by their coordination under common control." ${ }^{\text {es }}$

It was further pointed out in this case that the question of policy as to the common ownership of electric and gas facilities in the same territory was left to the states by Section

\footnotetext{
American Water Works \& Electric Company, 2 S.E.C. $97^{2}$ (1937).

${ }^{60}$ Id. at 983 .
} 
8 of the Act. ${ }^{66}$ The decision in this case was no doubt colored by the fact that it was a voluntary proceeding under Section I I (e) of the Act and further that it was the first integration decision handed down by the Commission. The Commission had not yet completely oriented itself and was subsequently forced to retract the broad rule laid down in this case.

Three years later substantially the same issue was presented in the Section I I (e) application of Columbia Gas \& Electric Corporation. Here the applicant owned gas service companies in Ohio, Pennsylvania, West Virginia, Kentucky, New York, Maryland, Virginia, and Indiana. It also owned electric service companies in Ohio, Kentucky, and Indiana. The electric service area was smaller than, but included within, the general boundaries of the gas service area. The gas facilities were for the most part interconnected and derived their gas from a common source. The electric operating companies were interconnected, with one exception. Both the electric and the gas operations constituted substantial activities, as contrasted with the situation in the American Water Works case where the gas operations were small in comparison with the electric operations. Columbia contended that the combined electric and gas facilities constituted a single integrated utility system and cited the American Water Works

${ }^{* 6}$ Section 8 of the Act provides as follows:

"Whenever a State law prohibits, or requires approval or authorization of, the ownership or operation by a single company of the utility assets of an electric utility company and a gas utility company serving substantially the same territory, it shall be unlawful for a registered holding company, or any subsidiary company thereof, by use of the mails or any means or instrumentality of interstate commerce, or otherwise, -

"(I) to take any step, without the express approval of the State commission of such State, which results in its having a direct or indirect interest in an electric utility company and a gas utility company serving substantially the same territory; or

"(2) if it already has any such interest, to acquire, without the express approval of the State commission, any direct or indirect interest in an electric utility company or gas utility company serving substantially the same territory as that served by such companies in which it already has an interest." 
case. The Commission held to the contrary. ${ }^{67}$ The decision states that the American Water Works case was merely an advisory opinion regarding compliance with Section II(b) of the Act which should be narrowly construed. Although the American Water Works involved a voluntary plan for compliance under Section II (e), the opinion appears to be final on the integration question. It was further noted that no specific definition appears in the Act with reference to an integrated public-utility system operating both gas and electric utilities. Section 8 of the Act was rejected as a controlling consideration. The principal point of distinction between the two cases lay in the fact that the gas facilities of American Water Works were small in comparison with the electric facilities, whereas both were substantial operations in the Columbia case. The Commission advanced the suggestion that the opinion in the American Water Works case should be construed to mean that the gas utility system was retainable as an additional system along with the integrated electric utility system. This was certainly not the decision in that case. In any event, the Commission rejected the American Water Works decision as controlling in the Columbia case. ${ }^{68}$

A short time later the American Water Works decision was laid to rest in the United Gas Improvement Company (U.G.I.) case. ${ }^{69}$ Here the company contended that its principal system was located in the Pennsylvania-Delaware-Maryland area, and that such system included both its electric and gas operations in that area. ${ }^{70}$ The Commission again rejected this contention. The company relied upon the American

${ }^{67}$ Columbia Gas \& Electric Corporation, 8 S.E.C. 443 ( I 94 I).

${ }^{68} C f$., comment, "Geographic Integration under Section I I (b) (I) of the Public Utility Holding Company Act," 36 ILL. L. R. 662 (1942).

${ }^{\circ}$ The United Gas Improvement Company, 9 S.E.C. 52 (194I).

${ }^{70}$ The opinion states that the "principal utility assets" of U.G.I. in this area were electric utility assets, but that gas properties were also included in the same area. No comparative figures were given. The United Gas Improvement Company, 9 S.E.C. 52, 77 (1941). 
Water Works case as an authority, but was confronted with the Columbia case. The Commission noted the anomalous position of U.G.I., which was requesting the Commission, on the basis of stare decisis, to overrule its latest decision on the point. The bothersome language in Section 8 of the Act was explained away by emphasizing the fact that one company might own both electric and gas facilities under the Act, when one was considered the principal integrated system and the other met the statutory test for an additional system or systems. The company contended that the word "and" connecting the two definitions in Section 2(a)(29) of the Act indicated that a combination of both gas and electric properties was contemplated within a single system. The phrase "(B) As applied to gas utility companies," in that section and the use of the term "single system" in both clauses (A) and (B) thereof led the Commission to the conclusion that a single integrated utility system might be composed of electric or gas properties, but not both.

The principal shortcoming of the position taken by U.G.I. was that the Act contained no standards which could be applied by the Commission to the combination of electric and gas properties in a single system. There was no over-all standard which might be applied to a combination of both.

U.G.I. further contended that joint gas and electric operations in the same area met the requirements of the concept of a single integrated system, as contemplated by Congress, on the grounds that a severance of gas and electric properties would be unnatural and wholly inconsistent with engineering and economic facts. The Commission pointed out that the assumption that unless the two functions might be combined in a single system, they might not be combined at all, was fallacious. A company may, of course, hold both types of properties, one as the principal system and the other as an additional system or systems, if the statutory standards are met. 
U.G.I. argued that the legislative history of the Act indicated that Congress intended that both gas and electric properties might be embraced in a single integrated system. The answer was that the early Congressional discussion of the bill did indicate that both gas and electric properties were to be included in one single integrated system, but such discussion occurred before the provision for "additional systems" was put into the bill. U.G.I. cited further the Conference Report which indicated that the definition of an integrated public utility system was intended to carry the same meaning as the earlier language. ${ }^{71}$ The Conference Report evidenced the fact, however, that under the provisions of Section 2(a)(29) gas and electric properties were intended to comprise separate systems. ${ }^{72}$

The conclusion was, therefore, that a "single integrated system" may not include a combination of both electric and gas properties. This holding is supported by the weight of reason. It would not have caused the Commission so much difficulty had it not been for the early contrary decision in the American Water Works case. Although not bound by the doctrine of stare decisis, the Commission exerted some effort in that direction in the Columbia Gas \& Electric Corporation case, but abandoned its earlier ruling completely in the U.G.I. case.

This holding in the Columbia Gas \& Electric Corporation and U.G.I. cases has been consistently adhered to in later decisions. ${ }^{73}$ It does not matter whether the gas properties

"H.R. Report No. 1903, 74th Cong., ist Sess. (1935), p. 69.

${ }^{72} I d$. at 66.

${ }^{73}$ Eastern Utilities Associates, Release No. 9784 (April 4, 1950); Philadelphia Company, Release No. 8242 (June I, I 948); The Commonwealth \& Southern Corporation, Release No. 76 I $_{5}$ (August 1, 1947) (gas utility operations small in comparison with electric utility operations); Peoples Light \& Power Company, 20 S.E.C. 357 (1945) (electric utility operations small in comparison with gas utility operations); Columbia Gas \& Electric Corporation, I 7 S.E.C. 494 ( I 944); Laclede Gas Light Company, I6 S.E.C. 26 (1 944); 
are large or small in relation to the electric properties; the American Water Works case has been completely discarded on this issue.

The Commission has been affirmed in this matter by the Court of Appeals for the District of Columbia in the Philadelphia Company case. ${ }^{74}$ The court stated its position as follows:

"... Plainly there are two defined types of 'integrated public-utility system' and the requirements of the gas type differ from those of the electric type. Just as plainly there is no third type. The Commission rightly refused to formulate a third definition. ....”75

With reference to the provisions of Section 8 of the Act relied upon by the company to support its contentions, the court pointed out that, although Section 8 did not prohibit a holding company from acquiring interests in both electric and gas companies serving the same territory unless the acquisition would violate the law of a state, such section did not authorize the acquisition of any property, and such acquisition had to meet the tests of Section IO(c), which in turn led back to Section I I (b).

It should be noted at this point that the application of the integration standards of the Act has been varied by the Commission, depending upon whether the problem involves the extent of a presently existing system or whether it involves additions thereto. It has been held that a proceed-

Cities Service Company, 15 S.E.C. 962 (1944); Cities Service Power \& Light Company, 14 S.E.C. 28 (1943); Engineers Public Service Company, I 2 S.E.C. 41 (1942); The North American Company, I I S.E.C. 194 (1 942); Standard Power \& Light Corporation, 9 S.E.C. 862 (1941); Philadelphia Company, 9 S.E.C. 532 (1941); and Virginia Electric \& Power Company, 9 S.E.C. 461 (1 941 ).

${ }_{74}$ Philadelphia Company v. Securities \& Exchange Commission, I77 F. (2d) 720 (C.A.D.C., 1949 ).

${ }^{75} I d$. at 723 . 
ing under Section I I (b) (I) to delimit the spheres of existing control is different from one in which the processes of the Act are sought to be used to extend control. ${ }^{78}$ For example, under Section I I(b)(I) utility properties may be retained even if they are not integrated with a principal retainable unit, but form a permissible additional system under the $A B C$ clauses of the section. But under Section Io of the Act an acquisition of securities or utility assets of a public utility company can be permitted only if it can be affirmatively found that such acquistion will tend towards the creation of an integrated system as defined in Section 2 (a) (29), ${ }^{77}$ and the acquisition must be disapproved if it is found that it will tend towards the concentration of control of public utility companies of a kind or to an extent detrimental to the public interest or the interest of investors or consumers. ${ }^{78}$ The position of the Commission is that the difference is not an accident of rhetoric, but inheres in the difference between Section I I, as a compromise of the policy of "elimination" of holding companies to which the Act is basically directed, ${ }^{79}$ and the "new acquisition" standards of Section Io which were designed to be a more restrictive check on the further growth of holding companies and the extension of their control. ${ }^{80}$ Unless the Commission is appraised of the precise context in which the integration question is presented, it will refuse to act because it will not be certain which set of standards is applicable. ${ }^{81}$ The policy is, therefore, to forgive past "mistakes" to a certain extent but to apply a strict rule to future action. It appears to be a natural development under the

${ }^{78}$ American Gas \& Electric Company, Release No. 6639 (May 17, I946).

"Section Io(c) (2).

${ }^{78}$ Section ro(b) ( $\mathrm{r}$ ).

${ }^{70} C f$., Section I (c) of the Act.

${ }^{80}$ American Gas \& Electric Company, Release No. 6639 (May 17, 1946), mimeo. p. 9.

${ }^{81}$ The North American Company, Release No. 6692 (June II, 1946). 
circumstances; however, it will lead to numerous inequities, as pre-existing systems will be allowed a greater degree of scatteration than new systems.

\section{Selection of the Principal System}

The nucleus of the utility properties which may be retained under the provisions of Section I I (b) (I) of the Act is referred to therein as the "single integrated public-utility system." The need for a shorter name for this group of properties is obvious, and the term that has been adopted is "principal system." Although this term does not appear in the Act, it is commonly used with reference to the "single integrated public-utility system" permitted by Section I I (b) (I), and it was used by Congress before the Act became law. ${ }^{83}$

Where there are two or more utility systems controlled by one holding company the problem of designating the "principal system" often arises in proceedings under Section I I (b) (I).$^{84}$ The various holding companies have generally been reluctant to designate a principal system, endeavoring not to commit themselves prematurely to any one particular system. The Commission has likewise been hesitant to issue final orders delimiting principal systems, and yet neither the holding companies nor the Commission has ever conceded (I94).

Engineers Public Service Company, 12 S.E.C. 4 I (1942), 9 S.E.C. 764

${ }^{3}$ Conference Report, H. R. Rep. No. 1903, 74th Congress, ist Sess. (1935), p. $7 \mathrm{I}$.

${ }^{84}$ The holding company may designate the principal system in a plan filed pursuant to Section II (e). Section I I (e) provides, in part, as follows:

"In accordance with such rules and regulations or order as the Commission may deem necessary or appropriate in the public interest or for the protection of investors or consumers, any registered holding company or any subsidiary company of a registered holding company may, at any time after January I, 1936, submit a plan to the Commission for the divestment of control, securities, or other assets, or for other action by such company or any subsidiary company thereof for the purpose of enabling such company or any subsidiary company thereof to comply with the provisions of subsection (b)...." 
that the other had the right to designate the principal system. In an early Section II(b) (I) case $^{85}$ this question as to whether the Commission or the holding company had the sole right or duty to select the principal system arose, but the Commission did not decide the question squarely at that time, holding that if it was the right of the holding company to make the selection, then the holding company had the duty of making the selection promptly. The issue was settled in this case by the Commission giving its consent to the issuance of an advisory opinion with reference to the principal system, which opinion would set forth the alternatives open to the holding company. The case contains this language:

"The Act does not expressly state whether the selection of the 'single integrated public-utility system' retainable as the principal system is for the holding company to make solely on the basis of its own wishes, or for us to make on the basis of evidence and with due regard to the public interest and the protection of investors or consumers. An intermediate position might be that the holding company may make the selection subject to our approval or disapproval based upon evidence and judged in the light of the foregoing standards. ${ }^{38}$

On appeal the position of the Commission in the Engineers Public Service Company case was affirmed. ${ }^{87}$ The holding was to the effect that it was reasonable to assume that the holding company rather than the Commission had the right of choice,

${ }^{85}$ Engineers Public Service Company, 9 S.E.C. 764 ( $194 \mathrm{I}$ ).

${ }^{86}$ Id. at 788. In The North American Company, II S.E.C. 7I5 at 716 (1942), the Commission stated that "It may very well be that the ultimate responsibility for designating the principal system rests with us, but in making that designation we would certainly give considerable weight to the expressed desires of the respondent holding company."

${ }^{87}$ Engineers Public Service Company v. Securities \& Exchange Commission, 138 F.(2d) 936 (C.A.D.C., 1943). See, also, The United Gas Improvement Company v. Securities \& Exchange Commission, I 38 F.(2d) roro (C.C.A., 3d. Cir., 1943 ). 
since the holding company was the lawful owner of the properties and the public interests were protected by the Commission's powers under the Act. This interpretation also avoided the contention that the delegation of arbitrary power to the Commission to select the principal system without Congressional standards to guide it would be unconstitutional. The court pointed out that the holding company could not unduly delay the selection of a principal system and thereby impede enforcement of the Act, and if the holding company did not act seasonably, then it was the duty of the Commission to make the selection. The court further sanctioned advisory findings where a selection could not be made intelligently by the holding company until the permissible composition of alternate systems had been determined. ${ }^{88}$

In the proceedings involving The North American Company, that company was requested by the Commission on several occasions to specify its principal system. ${ }^{89}$ North American refused to do so, contending that it should be free to dispose of its non-retainable properties as circumstances permitted without being bound in advance to determine which system would be retained. North American requested that alternative findings be made as to its principal system. The Commission rejected the first contention and also declined to issue an advisory opinion on the ground that a complete record had been made in the case and the issuance of an advisory opinion would only result in unnecessary complications and delay. The Commission then selected one group of North American properties as the principal system, stating

${ }^{88}$ The Commission issued advisory opinions with reference to principal systems in the early stages of the integration program. The Commonwealth \& Southern Corporation, Release No. 2626 (March 19, I 94I) ; Engineers Public Service Company, Release No. 2607 (March 11, 1941); The United Gas Improvement Company, Release No. 2500 (January 18, I94I); and Columbia Gas \& Electric Corporation, 8 S.E.C. 443 (1 94 I).

${ }^{80}$ The North American Company, I I S.E.C. 194 (1942). 
that North American had "indicated" that it would prefer this group as its principal system, and that in the opinion of the Commission the retention of this group as the principal system was appropriate. In effect, therefore, the Commission decided that North American should select this group and then proceeded on the assumption that that selection had been made. North American protested against this mode of procedure on appeal, but the Commission was sustained. ${ }^{90}$ North American argued that it could not then tell which two of its three systems would be most marketable, that Section I I (c) ${ }^{91}$ of the Act gave it at least one year for compliance with the divestment order, and that therefore it could select its principal system at any time within the period allowed for compliance. This argument was rejected on the grounds that such procedure would result in unnecessary delays and that it was the Commission's duty to act under Section I I (b) "as soon as practicable." If any changes occurred during the period allowed for compliance with the order, the Commission would have the power to revoke or modify its order.

Cities Service Power \& Light Company likewise failed to indicate which of its utility systems it preferred as its principal system, contending that it should be free to dispose of properties without being a forced seller. The contention was again rejected, the Commission noting that sale is only one of the many means of divestiture which may be used in compliance with orders of disposition. ${ }^{92}$ The procedure adopted

"The North American Company v. Securities \& Exchange Commission, 133 F. (2d) 148 (C.C.A., 2 d Cir., 1943 ).

${ }^{81}$ Section 1 i (c) provides as follows:

"Any order under subsection (b) shall be complied with within one year from the date of such order; but the Commission shall upon a showing (made before or after the entry of such order) that the applicant has been or will be unable in the exercise of due diligence to comply with such order within such time, extend such time for an additional period not exceeding one year if it finds such extension necessary or appropriate in the public interest or for the protection of investors or consumers."

${ }^{82}$ Cities Service Power \& Light Company, I4 S.E.C. 28 (1943). 
in this case was to define all possible principal systems and then to issue an order of divestment based upon a principal system designated by the Commission, with a reasonable time being given the holding company to indicate a different choice. The time set by the Commission was I 5 days, after which time the order was to become final. ${ }^{93}$

The Commission will not, however, spell out the limits of all possible principal systems where it is reasonably clear what properties constitute the principal system and the holding company indicates that it desires to retain such properties as its principal system. ${ }^{94}$ And where the holding company proposes to divest itself of all of its utility subsidiaries, ${ }^{95}$ or proposes to dispose of all of its subsidiaries and dissolve, ${ }^{9 \theta}$ both the Commission and the holding company are relieved of the burden of selecting a principal system.

\section{Integration as Applied to Particular}

Electric Utility Systems

The definition of an integrated electric utility system, as contained in Section 2(a)(29)(A) of the Act, has already been stated. The basic elements requisite to such a system are as follows:

(I) Physical interconnection or capability thereof;

(2) Economical operation as a single interconnected and coordinated system;

* The protest of Cities Service Power \& Light Company to this procedure was overruled by the Commission in 14 S.E.C. 233 (1943). The same procedure was used by the Commission in Cities Service Company, 15 S.E.C. 962 (1944).

Columbia Gas \& Electric Corporation, I 7 S.E.C. 494 (1944).

${ }^{96}$ American Water Works \& Electric Company, Release No. 6489 (March I 8, 1946); Koppers Company, Inc., I 9 S.E.C. 608 (1945).

${ }^{8}$ Federal Water \& Gas Corporation, Release No. 7945 (December I8, I947); Crescent Public Service Company, Release No. 6115 (October 9, 1945); North Continent Utilities Corporation, 14 S.E.C. 656 (1943); and Great Lakes Utilities Company, I I S.E.C. 87 ( 1942 ). 
(3) Confinement of operations to a single area or region; ${ }^{97}$

(4) (a) Not so large as to impair the advantages of localized management, (b) efficient operation, and (c) the effectiveness of regulation, considering the state of the art and the area or region affected.

The relative weight given by the Commission to these various elements will be revealed in the following study of the integration decisions.

\section{Standard Power Es Light Corporation}

The Standard Power \& Light Corporation and Standard Gas \& Electric Company and their subsidiary companies in I 941 operated in 20 states and Mexico. ${ }^{98}$ The Commission remarked that Standard typified the kind of "scatteration" and tendency toward undue concentration of ownership which Section I I (b) ( I ) was designed to eliminate. ${ }^{99}$ Standard proposed to limit itself to its Philadelphia Company properties, operating in and around Pittsburgh, Pennsylvania, and no attempt was made to correlate any of the other widely scattered properties unto the utility system of the Philadelphia Company. The electric utility assets were owned by Duquesne Light Company, a subsidiary of Philadelphia Company, and consisted of generating plants, transmission lines, and distribution facilities, with a book value of approximately $\$ 2$ I 8,598,000.00 on December 3I, I940, serving approximately 374,000 customers of a total population of $r, 400,000$ in Pittsburgh and environs, being physically interconnected

${ }^{27}$ There is conflict of opinion as to whether this is a separate element, or an integral part of element (4). This conflict will be discussed below.

${ }_{83}$ The electric utility properties of these companies were concentrated mainly in the States of Pennsylvania, Minnesota, Wisconsin, Oklahoma, Colorado, Wyoming, Montana, Oregon, and California.

${ }^{9}$ Standard Power \& Light Corporation, 9 S.E.C. 862 ( 194 r). 
and functioning as a single coordinated system. The area served did not exceed 50 miles east and west or north and south, the total being approximately $8 \mathrm{I} 7$ square miles. These properties were held to be an integrated electric utility system. ${ }^{100}$ There was no special analysis of the system with reference to the size requirements three and four above; however, from what has already been shown it is clear that all of these requirements were met.

\section{The United Gas Improvement Company}

The operations of The United Gas Improvement Company were fairly well concentrated in the northeastern part of the United States, except for its subsidiary, Arizona Power Corporation, located in the central portion of Arizona. ${ }^{101}$ The most extensive U.G.I. electric utility operation was carried on in the southeast portion of the state of Pennsylvania and in the adjoining northern portions of the states of Maryland and Delaware. This system covered an area approximately 80 miles by 30 miles with a population of $3,000,000$ persons. U.G.I. conceded that this constituted its primary or principal system. ${ }^{102}$ The Commission in its statement of tentative conclusions with reference to U.G.I. held that the Pennsylvania-Maryland-Delaware electric utility properties constituted a single integrated system. ${ }^{103}$ The Commission has subsequently proceeded upon the assumption that the principal electric utility system of U.G.I. lies within the 3-state area, but has not defined its exact limits. ${ }^{104}$ U.G.I. complained of this method of procedure in its appeal to the Third

${ }^{100}$ Ibid. See also, Philadelphia Company, Release No. 8242 (June 1, 1948). ${ }^{101}$ Divestment of the Arizona Power Corporation properties was ordered in The United Gas Improvement Company, 9 S.E.C. 52, 63-64 (I94I).

${ }_{103}$ The United Gas Improvement Company, 9 S.E.C. 52 (1941).

${ }^{103}$ The United Gas Improvement Company, Release No. 2500 (January I 8, I 94 I).

${ }_{104}$ The United Gas Improvement Company, 9 S.E.C. 52 (I94I). Cf., The United Gas Improvement Company, Release No. 10624 (June 15, 1951 ). 
Circuit of Appeals. That court rejected the complaint, observing that there might be circumstances in which the determination of a holding company's single integrated utility system is necessary, but that such circumstances were not presented in this case. ${ }^{105}$ The properties in question served a very compact area. In the absence of some unusual circumstance not yet revealed in any of the opinions of the Commission, these properties undoubtedly constitute an integrated electric utility system. The procrastination of the Commission in making a final decision in this regard is difficult to understand.

\section{American Water Works ES Electric Company}

The electric operations of American Water Works and Electric Company were carried on in Pennsylvania, West Virginia, Ohio, Maryland, and Virginia, covering an area approximately 300 miles north and south and 300 miles east and west. The electric properties were mostly physically interconnected, and those not so connected were capable of physical interconnection and interconnections were proceeding apace.

With no discussion of the other requirements of integration, the Commission held that these properties constituted a single integrated electric utility system. ${ }^{108}$

\section{Engineers Public Service Company}

Engineers Public Service Company operated electric utilities in 15 widely scattered states. ${ }^{107}$ The electric properties

${ }^{105}$ The United Gas Improvement Company v. Securities \& Exchange Commission, 138 F.(2d) 10 ro (C.C.A., 3d Cir., 1 943 ).

${ }^{100}$ American Water Works \& Electric Company, 2 S.E.C. 972 (1937). This case held that the electric and gas properties combined constituted an integrated utility system, a principle which the Commission later repudiated.

${ }^{107}$ See map of Engineers Public Service Company electric utility systems on page 42. The source of this map is Engineers Public Service Company, 9 
in Virginia and North Carolina served an area of 13,500 square miles, extending 240 miles north and south, and I 40 miles east and west. The population of this area was 830,000 of which I 70,000 were customers of the electric system. The system was physically interconnected or capable of such interconnection, and was subject to regulation by state commissions in Virginia and North Carolina. The Commission held this system to be integrated. ${ }^{108}$ The small interconnected system serving the city of Savannah, Georgia, was also held to be integrated. ${ }^{109}$ Engineers' properties in southeast Texas and southern Louisiana (Gulf States Utilities Company) extended approximately 350 miles east and west, and from 50 to 125 miles north and south, serving an area of 27,000 square miles with 92,000 customers out of a population of 405,000. The utility system was subject to municipal regulation in Texas and state regulation in Louisiana. The properties of this system were physically interconnected or economically capable thereof. This system was found to be integrated. ${ }^{110}$

The properties of Engineers located at Alvin, Texas, were held not to be integrated. ${ }^{111}$ This system was not physically interconnected with the other properties belonging to Engineers and was not economically capable of such interconnection. Its electric energy was purchased from a non-affiliated company. Engineering, accounting, purchasing, billing, rates, taxes, etc. were handled by a general office of Engineers in Beaumont, I I 2 miles distant. The system served less than I,, 000 customers. Alvin was obviously an orphan. Engineers

S.E.C. 764 ( $194 \mathrm{I})$. The enclosures indicating the integrated areas have been added.

${ }^{108}$ Engineers Public Service Company, 9 S.E.C. 764 (1941). See Engineers Public Service Company, 12 S.E.C. 4 I (1942).

${ }^{108}$ Engineers Public Service Company, 12 S.E.C. 41, 62 (1942).

${ }^{10}$ Engineers Public Service Company, 9 S.E.C. 764 (1941). See Engineers Public Service Company, 12 S.E.C. 41 (1942).

${ }^{111}$ Engineers Public Service Company, I 2 S.E.C. 41, 82-83 (1942). 


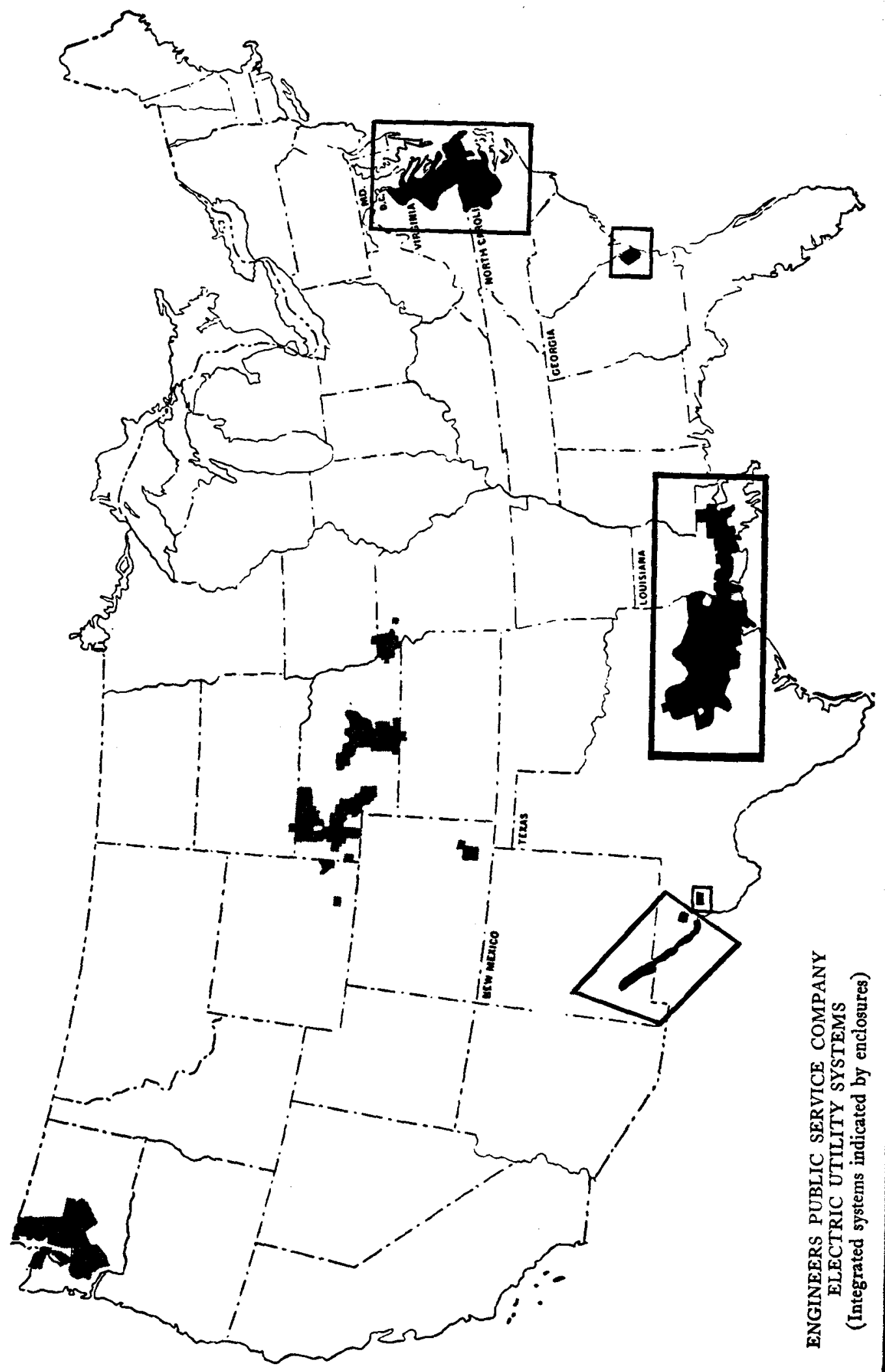


also owned a small electric utility system at Jasper, Texas, 73 miles from Beaumont. Like Alvin, it was not connected with the main Engineers properties and was not economically capable thereof. The Beaumont offices furnished the same overhead services that were rendered for Alvin. The two properties differed only in the fact that Jasper derived its power from its own diesel generating plant. The Jasper properties were held to be an integrated electric utility system. ${ }^{112}$

The electric system of Engineers in west Texas and southern New Mexico, the El Paso system, served an estimated population of 169,000 in an area of 700 square miles. Its territory followed the Rio Grande Valley for a distance of 220 miles, rarely exceeding 5 miles in width. The region served was surrounded by mountains and desert, and was geographically isolated. With the exception of electric utility properties serving the city of Sierra Blanca and Van Horn, Texas, the system's properties were entirely interconnected. The Sierra Blanca properties were in the process of being interconnected with the main system. The Commission found that with the exception of the Van Horn properties these electric utility properties constituted an integrated public utility system. ${ }^{113}$

The Van Horn properties, mentioned above, served 200 customers in a small isolated area. These properties were not economically capable of interconnection with the other properties of Engineers in the region. The latter system assisted Van Horn with production, distribution, and engineering. Van Horn generated its own energy from a diesel plant. The system was held to be integrated. ${ }^{114}$ This is the smallest integrated system yet defined by the Commission.

\footnotetext{
112 Id. at 84 .

${ }^{113} I d$. at 86 .

${ }^{114} I d$. at 90 .
} 


\section{PUBLIC UTILITY HOLDING COMPANIES}

\section{The North American Company}

The most comprehensive of the early integration decisions of the Commission was rendered in The North American Company case. ${ }^{115}$ The North American Company system was comprised of 80 companies operating in 18 states serving 3 million customers over an area of some 165,000 square miles. ${ }^{116}$ Upon the failure of the company to designate its principal system within this vast empire, the Commission selected the electric utility system of the Union Electric Company of Missouri and its subsidiaries as such system, on the grounds that North American had indicated that it would prefer that choice and that the Commission would regard the retention of that system as appropriate if called upon to pass on the choice of this system by North American. This Commission-selected principal system operated an electric utility system in Missouri, Illinois, and Iowa. Its operations were centered around St. Louis, Missouri, East St. Louis, Illinois, in an area surrounding a large hydroelectric plant at Keokuk, Iowa, and in and around a hydroelectric plant at Osage, Missouri. Note that the Keokuk and Osage properties were each approximately roo miles from the main concentration of properties around St. Louis. The total area served contained 3,100 square miles with a population of $I, 500,000$ of which $35 \mathrm{I}, 565$ were customers. All electric production facilities of the group were physically interconnected and centrally controlled, and were coordinated without reference to differences in corporate ownership. The system was subject to state regulation in Missouri and Illinois and to municipal regulation in Iowa. This group of properties was held to be

115 The North American Company, i I S.E.C. I 94 ( I 942).

${ }^{116}$ See map of The North American Company electric utility systems on page 45. The source of this map is The North American Company, Release No. 3405 (April 14, 1942). The enclosures indicating the integrated areas have been added. 


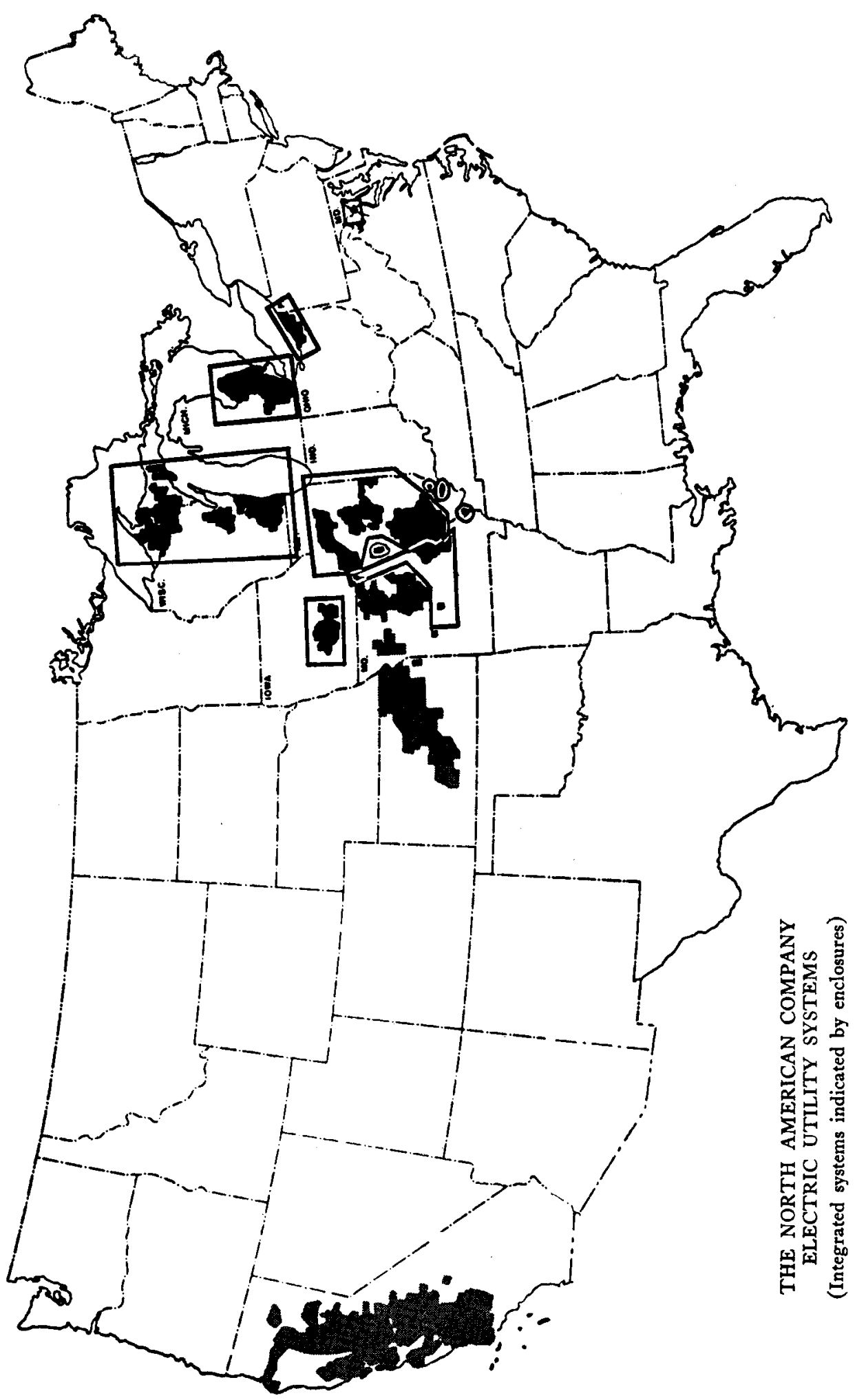




\section{PUBLIC UTILITY HOLDING COMPANIES}

a single integrated electric utility system. ${ }^{117}$

With practically no discussion of the controlling factors, the Commission held that the electric utility systems of The North American Company centered around Washington, D.C., Cleveland, Ohio, Detroit and southeastern Michigan, and in the Wisconsin-Michigan region ${ }^{118}$ were each single integrated electric utility systems. ${ }^{119}$ The map of The North American Company system substantiates this holding with reference to the Washington, Cleveland, and southeast Michigan properties. However, the Wisconsin-Michigan system would seem to justify a more searching analysis by the Commission. This system consisted of three concentrations of electric properties extending from the southern border of Wisconsin into the northern reaches of Wisconsin and into the northern peninsula of Michigan, a distance of 300 miles. In northern Wisconsin and Michigan the properties extended I 75 miles east and west. There were substantial gaps in the service areas of these properties. No doubt the proper integrational factors existed, but they did not appear on the surface and the opinion does not provide further enlightenment.

This system was held to be non-retainable as an additional system to the Union Electric Company, and perhaps this induced the Commission to consider the question of integration only briefly. Since the issue of integration becomes of paramount importance with regard to each system sooner or later, it seems unfortunate that so little emphasis should be placed upon it in this particular case. ${ }^{120}$

${ }^{117}$ The North American Company, I I S.E.C. I 94 ( 1 942 ).

${ }^{118}$ See map on page 45.

119 The North American Company, I I S.E.C. I94 (1942). Appendix B of this decision sets forth the area, population, and number of customers served by each company in these areas. Counsel for the Public Utilities Division of the Commission had conceded that these properties were integrated.

${ }^{120}$ See Wisconsin Electric Power Company, 9 S.E.C. 941 (1941), which indicates the presence of economical, efficient, and coordinated operation of these properties. 
The subsidiaries of Illinois Traction Company, in turn a subsidiary of The North American Company, operated two large electric utility systems and several smaller electric properties. One of the larger systems, located in northern, central, and southern Illinois, was operated by Illinois Iowa Power Company, and Kewanee Public Service Company. The other was operated in south central Iowa by Des Moines Electric Light Company and Iowa Power \& Light Company. North American contended that all of these properties constituted a single integrated electric utility system. Illinois Iowa Power Company and Kewanee Public Service Company operated in an area of 15,333 square miles with a population of 750,000 including 223,338 customers. Their properties extended 250 miles north and south, and 180 miles east and west. Des Moines Electric Light Company and Iowa Power \& Light Company served 65,955 customers out of a population of 290,000 in a compact area of 3,240 square miles, extending IO2 miles east to west, and 52 miles north to south. The Iowa properties combined with those in Illinois extended 330 miles from east to west, with a substantial gap between them. The Commission held that the electric operations in the main service territories in northern, central, and southern Illinois, including those of Kewanee, all of which were physically interconnected by means of lines owned or leased for joint use, constituted a single integrated system, the principal system for Illinois Traction Company. ${ }^{121}$ Electric operations in four small isolated areas adjacent to this main system were held not to be a part of such system. They were not interconnected with each other or with the main system. It was claimed by North American that the operation of the electric facilities in these areas was thoroughly coordinated and efficiently carried on. The Commission conceded that perhaps

1w The North American Company, II S.E.C. I 94 (1942). 
this was true with respect to the corporate management, but it did not believe that these electric facilities were or could be operated physically as a single interconnected and coordinated system. The position of the Commission was stated in this manner:

“... In determining the boundaries of an integrated electric utility system under Section 2(a) (29), we must find that the utility assets included therein are physically interconnected or are capable of such interconnection, and that these utility assets under normal conditions may be 'economically operated as a single interconnected and coordinated system.' . . We think it clear that the quoted language refers to the physical operation of utility assets (not the management of the company or companies owning them) as a single interconnected and coordinated system; that is, a system in which (inter alia) the generation and/or flow of current within the system may be centrally controlled and allocated as need or economy directs, and which is operated as a unit. Thus, even though we find physical interconnection exists or may be effected, evidence is necessary that in fact the isolated territories are or can be so operated in conjunction with the remainder of the system that central control is available for the routing of power within the system. We can make no such finding with respect to the four smaller areas. ..."122

The Commission found, however, that each of these four isolated units constituted a single integrated electric utility system, despite the fact that all of them took their power from Central Illinois Public Service Company, a non-affiliated company, and only one of them had a generating station. Although the Act does not require the existence of generating facilities within a single integrated system, it would seem that

${ }^{122} I d$. at 242 . 
they normally should be present, ${ }^{123}$ and therefore the decision as to the three properties wholly dependent upon an outside source of power would appear to be questionable.

With reference to the inclusion of the Iowa properties with the main facilities in Illinois as a single integrated system, it was stipulated that these properties were capable of physical interconnection, but the evidence indicated that they were separately operated and that there was then no physical interconnection between them except through facilities owned by other companies and running through foreign service territories. Physical connection of the two properties by means of their own facilities was not contemplated, nor was it possible within the reasonably near future. There was no showing that the Illinois and Iowa properties were operated as a "coordinated" system, or that such operation under "normal" conditions was possible. Consequently, the combination of the Illinois and Iowa properties was held not to be a single integrated electric utility system. The Iowa properties by themselves, however, being interconnected and operated as a unit, were held to be a single integrated system. ${ }^{124}$

The Union Electric Company system of The North American Company was subsequently enlarged by the addition of the electric properties of Missouri Power \& Light Company, a system subsidiary. Missouri provided electric and other services in three non-contiguous areas in the northern half of Missouri. The bulk of the electric system of Missouri was interconnected with that of Union at three points, and Missouri purchased approximately $40 \%$ of its electric energy requirements from Union. Missouri was also engaged in the electric distribution business at Clinton, Missouri, some 55 miles from

${ }^{12}$ Compare the treatment of the Alvin, Texas, properties of Engineers Public Service Company in Engineers Public Service Company, I2 S.E.C. 41 (1942). See pages 4 I, 43, supra.

${ }_{124}$ The North American Company, I I S.E.C. 194 (1942). 
the nearest electric properties of Union. The entire requirements at this town were purchased from a nonaffiliated company. The Union system and Missouri combined served an area extending from East St. Louis, Illinois, to Excelsior Springs, Missouri, a distance of about 260 miles, practically spanning the state. The total property and plant of the Union system at June 30,1950 , was $\$ 359,837,8$ I I, with net tangible property of $\$ 273,673,869$. Its electric operating revenues for the I 2 months ended June 30, 1950, amounted to $\$ 65,878,963$. The gross plant account of Missouri at the same date was $\$ 28,448, \mathrm{I} 88$, with net tangible property amounting to $\$ 23,780,57 \mathrm{I}$. The electric operating revenues of Missouri for this period were $\$ 6,606,700$. North American presented evidence to show that the acquisition of the control of Missouri through stock ownership by Union would facilitate the coordination of future power demands and would extend to the Missouri electric operations the benefits of the extensive experience of the Union staff with regard to engineering and other problems. In addition, it appeared that Union would be able to furnish financial aid to Missouri, particularly in obtaining new equity capital. The record also indicated that certain operating economies would result from integrating the Union system with Missouri's electric business. The acquisition of the stock of Missouri by Union was approved by the Commission under the provisions of Section IO(c) (2) and the combination of the electric properties of Missouri, except those at Clinton, with those of Union was held to constitute an integrated electric utility system. ${ }^{125}$. The Commission felt that this combination of properties was not so large as to defeat the size requirements of Section 2 (a) (29) (A) of the Act, in view of the comparatively small size of the Missouri electric properties as contrasted with those

${ }^{225}$ The North American Company, Release No. 10320 (December 28, 1950). 
of Union and in consideration of the fact that Missouri's electric operations were conducted in the same general area as those of Union.

\section{Cities Service Power E Light Company}

Cities Service Power \& Light Company and its subsidiary companies carried on electric utility operations in 14 states and Canada, extending from coast to coast. ${ }^{128}$ In general, the properties of the system were geographically divided into four sectional groups. The first was located in Ohio, and consequently referred to as the "Ohio group." The second, or "Mid-Continent group," was located in Arkansas, Kansas, Missouri, and Oklahoma. The third was the "Rocky Mountain group," operating in Arizona, Colorado, New Mexico, and Wyoming. The fourth consisted of scattered properties located in Connecticut, Michigan, North Carolina, Tennessee, Virginia, Washington, and Canada.

The Ohio group consisted of generating plants, transmission lines, and distributing facilities in a compact strip of territory in northern Ohio and in four smaller territories in the northeastern portion of the state. The properties of this group in the smaller areas were physically interconnected by means of group-owned transmission lines with each other and with the main service areas. The entire service area was approximately 200 miles from east to west, and was irregular in width. The properties were operated as a unit with respect to economical power interchange, and were amenable to regulation within a single state. The Ohio properties were accordingly held to be an integrated electric utility system. ${ }^{127}$

${ }^{120}$ See map of Cities Service Power \& Light Company electric utility systems on page 52. The source of this map is Cities Service Power \& Light Company, Release No. 4489 (August I7, 1943). The enclosures indicating the integrated areas have been added.

${ }^{12}$ Cities Service Power \& Light Company, 14 S.E.C. 28,4 I (1943). 


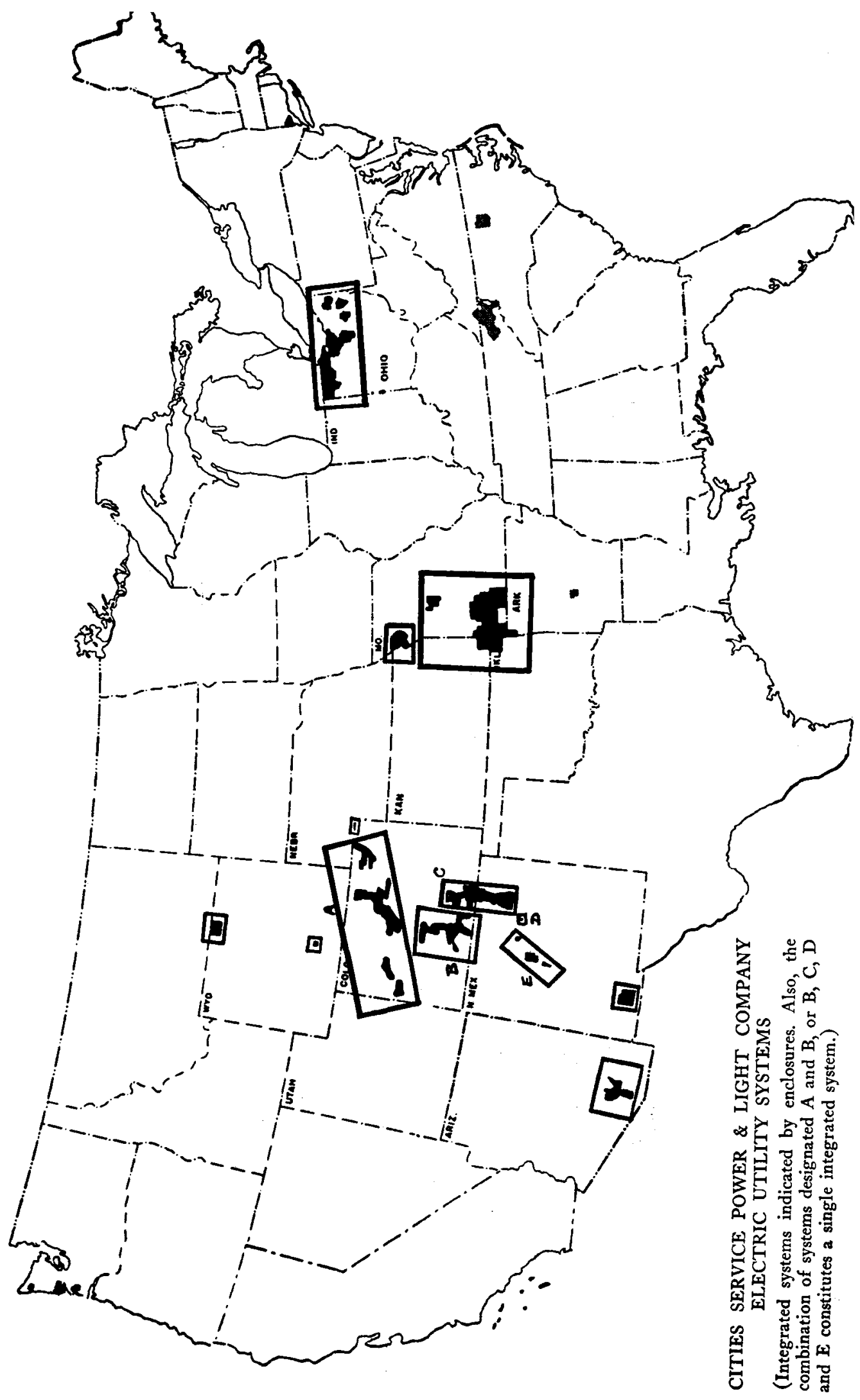


The major electric utility service area in the Mid-Continent territory lay in the southwestern part of Missouri and overlapped into southeastern Kansas, northeastern Oklahoma, and northwestern Arkansas. The system also served two smaller areas in the Mid-Continent section, one in central Missouri surrounding the city of Sedalia, and the other in northwestern Missouri and northeastern Kansas surrounding the city of St. Joseph, Missouri. The southwestern Missouri area was served by group-owned and interconnected generation, transmission, and distribution facilities. Its service area was compact, but irregular in shape, I 50 miles long and I 50 miles wide at its extremes. The properties situated in and around Sedalia, Missouri, owned by the City Light \& Traction Company, were separated from the main service area in southwest Missouri by about 65 miles. They were, however, physically connected with the larger system by a hightension transmission line belonging to these two systems. City Light \& Traction Company relied upon the generating facilities of the southwest Missouri properties for its power, and its physical operations were coordinated with those in the main service area. The Commission held that the combination of the southwest Missouri properties and the Sedalia properties constituted a single integrated electric utility system. ${ }^{128}$ Cities Service also contended that the properties in St. Joseph, Missouri, were a part of this same single system. The St. Joseph area was physically separated from all of the other system properties in the Mid-Continent territory, being over 100 miles from Sedalia, the nearest service center in the main integrated area of the system. This proposed system would have extended over 250 miles north to south. The St. Joseph properties had no operating relationship to the main system. Cities Service relied upon the decision in 
The North American Company case with reference to the Wisconsin-Michigan system and to the Union Electric Company system previously discussed. ${ }^{129}$ The Commission pointed out two distinguishing features in The North American Company case, however. First, in that case there were physical interconnections by means of transmission facilities; and second, the outlying properties were not, in the main, distribution centers, but contained large hydroelectric resources capable of supplying extremely economical power over long lines into the main part of the system. Further, even though Cities Service had given some thought to the interconnection of the St. Joseph properties with those of the main system in order to meet increasing power demands of the former, the Commission was of the opinion that such interconnection was not a natural geographical development and was too remote a possibility to be given any weight in these proceedings. Accordingly, the St. Joseph facilities were held not to be a part of single integrated system in Missouri. By themselves, however, they were held to be a single integrated system. ${ }^{130}$

The Rocky Mountain group was spread over a territory stretching from northern Wyoming to southern Arizona, with a concentration of properties in Colorado and northern and central New Mexico. The distance between the northern and southern extremes was 900 miles. Substantial portions of 'these properties were physically isolated from other properties in the section, and in several instances in which there was physical interconnection between properties, it was by means of lines not owned or controlled by the system. The largest operating company in the Rocky Mountain group was Public Service Company of Colorado. It operated in two sectors. One covered the northern part of Colorado,

${ }^{120}$ The North American Company, i I S.E.C. I 94 ( 1942 ).

${ }^{130}$ Cities Service Power \& Light Company, it S.E.C. 28,46 (1943). 
reaching to Cheyenne in southern Wyoming, and stretching almost to the extreme eastern and western ends of Colorado, a distance of 320 miles, its densest portion centering around the city of Denver. The other sector, the Salida-Alamosa division (designated " $B$ " on the map), extended north and south from Salida in central Colorado, through Alamosa and down to the southern border of the state, a distance of I rO miles. Both operating sections contained combined steam and hydroelectric production units, and interconnected transmission and distribution facilities, with minor exceptions. ${ }^{131}$ However, the two sets of properties were not physically connected, and each was operated as a coordinated, separate physical unit. Each set of properties was held to be a separate integrated electric utility system. ${ }^{\mathbf{1 3 2}}$

Cities Service forecast that by 1945 the Salida-Alamosa sector would need additional sources of power. It was proposed to procure the additional energy either by installing new generating units in the area, by interconnection with the Public Service Company properties to the north, or by interconnection with the properties to the east and south (Trinidad). Even though both such interconnections should be

${ }^{131}$ The northern portion of the Public Service Company properties contained two small areas which were not physically interconnected with the remainder of the system. These were at Estes Park, in the central part of Colorado, and at Sedgewick and Ovid in the extreme northeastern part of the state. The Estes Park properties were managed as an integral part of the Public Service Company properties; the Estes Park region contained local generation and distribution facilities, was extremely close to the remainder of the system, and could easily be interconnected therewith. Consequently, the Estes Park properties were held to be a part of the integrated system of Public Service Company. The properties at Sedgewick and Ovid, however, were about 25 miles from the nearest Public Service Company properties, contained no generating facilities, and received their entire power supply from outside sources. They did not form any natural part of the system of Public Service Company. Therefore, these properties were excluded from the integrated system of Public Service Company, and were further found not to be one or more integrated systems standing by themselves. Cities Service Power \& Light Company, I 4 S.E.C. 28 (1943).

${ }^{132}$ Cities Service Power \& Light Company, 14 S.E.C. 28, 53 (1943). 
made, there was no evidence showing that there would be routing and central allocation of power as between Public Service and Trinidad, or that it would be possible. Therefore, it was impossible for the Commission to find that the three sets of properties, Public Service, Salida-Alamosa, and Trinidad, together formed a single system which could under normal conditions be economically operated as a coordinated system. The proposed plans did not contemplate that kind of unitary, coordinated operation between the properties of either end of the chain which must exist under normal conditions before such properties could be found to be integrated, according to the Commission. However, the Commission held that either interconnection would result in the integration of the Salida-Alamosa properties with the properties to the north or to the east and south respectively. ${ }^{133}$ Thus, the Salida-Alamosa properties formed a possible part of two systems.

Between Walsenburg in southern Colorado and Wagon Mount in northern New Mexico, in a narrow strip of service area, were the interconnected properties of Trinidad and the Dawson division of New Mexico Power Company (designated "C" on the map). They extended I Io miles north and south. The properties, although in separate corporate ownership, were operationally and managerially closely linked. There was energy interchange and central load dispatching for both properties. These properties were held to constitute a single integrated system. ${ }^{134}$

Another set of Rocky Mountain properties was located at the city of Las Vegas, about 40 miles southwest of the southern terminus of the Trinidad-Dawson system. The Las Vegas Light \& Power Company was relatively small and was physically unconnected with the other system properties.

\footnotetext{
${ }^{138} I d$. at 54 .
}

${ }^{134} I d$. at 56 . 
It served 2,000 customers. The Las Vegas properties were found to be a single integrated electric utility system. ${ }^{135}$

South and west of Las Vegas lay a group of properties extending southward along the Rio Grande River from Santa Fe through Albuquerque, New Mexico, to Belen, New Mexico. The properties were interconnected by transmission lines running 90 miles north and south. This chain of properties was operated jointly, in spite of varying corporate ownership. They were designated as a single integrated system. ${ }^{136}$

Cities Service contended that it would be profitable to interconnect these three separate systems just described by a line running from the southern end of the Trindad-Dawson system via Las Vegas to the northern end of the Albuquerque properties. This required a 93-mile transmission line with extensive repairs on existing lines to recondition them for higher capacity. It was estimated that the total installation costs would amount to $\$ 465,000$. Because of lower costs at the Dawson plant, savings in operation would be effected, yielding a return on the investment of $\$ 59,269$ per year. There was no plan for undertaking these interconnections in the near future, but the Commission believed that these properties were capable of interconnection and coordinated operation as a single system, and therefore held that the electric utility properties of Trinidad, Las Vegas, and Albuquerque (shown as "C" "D" "E" on the map) constituted a single integrated system. ${ }^{137}$ The Commission also pointed out that although the Salida-Alamosa properties could be considered a part of the northern Colorado system or as a part of the properties to the south and east, as shown above, the latter combination would be more economical, efficient and

\footnotetext{
${ }^{135} \mathrm{Ibid}$.

${ }^{138}$ Ibid.

${ }^{187}$ Id. at 57 .
} 
feasible, and therefore more desirable.

Cities Service took the position that all of the properties of the Rocky Mountain system described thus far constituted one integrated system. This was rejected because the evidence did not show that this entire group of properties was or could be capable of the kind of unitary, economic operation comprehended by the Act, and because these properties combined exceeded the size limitations of Section 2(a) (29)(A) of the Act. On this latter issue the Commission made these observations:

"Section 2(a) (29) (A) in terms requires limitation to a single area or region. The mandate that we have regard for the "area or region" affected by retention of systems in combination in Section I I (b) (I) (C) points to the existence of highly similar standards in that section. ... The statute and its legislative history make it clear that, consistently with geographic conditions (in the broad sense of that term) as much compactness should be achieved in outlining the spheres of holding company influence as physical facts permit.

"The standard of localized management cannot be met by any combination of properties (as one or more systems) spread over a territory as vast as that covered by the States of Wyoming, Colorado, New Mexico and Arizona. We have noted that the north-to-south extremes of the system properties in this territory are 900 miles apart. From Sheridan County in northern Wyoming to the nearest Public Service properties (in Cheyenne) is 240 miles. At the other end of the system it is sought to retain properties in Deming, N.Mex., and Tucson, Ariz. From Tucson to the nearest of the compact properties in the system is 320 miles; from Deming to the same point is 200 miles; and from Deming to Tucson is approximately 200 miles. The outlying properties at Sheridan, Deming, and Tucson are not physically con- 
nected with any other property in the system, or with each other. All the intervening stretches between these properties are mountainous and sparsely settled.

* * * *

". . . Read as respondents wish the Act to be read, it would comprehend hegemonies of holding-company control so vast that (under the area or region standard) the Act would permit a few holding companies to divide the country. The language of the Act does not permit, and Congress did not intend, such a result." "138

Although the system properties in Sheridan, Deming, and Tucson were held not to be in the same area or region with the remainder of the system properties or with each other, each was held to be a separate integrated utility system. The small set of properties at Rawlins, Wyoming, was also held to be a single integrated system.

In a subsequent proceeding, Cities Service endeavored to show that the Deming and Tucson systems were an integrated part of the Trinidad-Las Vegas-Albuquerque system of its subsidiary, Federal Light \& Traction Company (hereinafter called the "New Mexico system"). ${ }^{139}$ Evidence was adduced to prove that the United States Bureau of Reclamation (U.S.B.R.) intended to interconnect the Deming and Tucson properties, and also to interconnect the Deming properties with the New Mexico system. The completion of these proposed lines would therefore result in interconnection of all three systems. The Commission held, however, that physical interconnection, standing alone, was not enough, and that this combination of properties was not capable of economic operation as a coordinated system. The 375 miles of line between Tucson and Deming, to be constructed by the

${ }^{138} I d$, at 59.

${ }^{199}$ Cities Service Power \& Light Company, 15 S.E.C. 675 (1944). 
U.S.B.R., would have been out of system control. The U.S.B.R. lines might have provided additional sources of power for these properties, but they could not be used for intra-system power conveyance, and consequently coordinated use thereof by the Cities Service subsidiaries was impossible. There was further testimony that interconnections of the Tucson, Deming, and New Mexico properties were being considered independently of the U.S.B.R. program. Such a program was considered to be highly uneconomical by the Commission. Therefore, the Commission again arrived at the conclusion that the Tucson and Deming properties did not form an integrated system along with the New Mexico properties.

\section{The Commonwealth E Southern Corporation}

In the tentative conclusions of the Commission with reference to The Commonwealth \& Southern Corporation holding company system, the only properties held to be integrated were those located in eastern Ohio and western Pennsylvania. ${ }^{140}$ These properties were interconnected and extended I Io miles east and west, and roo miles north and south. However, this decision gave small consolation to Commonwealth \& Southern, which operated large systems elsewhere, particularly in Michigan and in five southern states, Mississippi, Alabama, Georgia, Florida, and South Carolina. In a plan submitted under Section i I (e) of the Act, Commonwealth \& Southern proposed to group the properties in Mississippi, Alabama, Georgia, and Florida together as its principal integrated electric utility system. ${ }^{141}$ These properties

${ }^{140}$ The Commonwealth \& Southern Corporation, Release No. 2626 (March I 9, I 94I). See map of The Commonwealth \& Southern Corporation electric utility systems on page $6 \mathrm{r}$. The source of this map is The Commonwealth \& Southern Corporation, Release No. 1956 (March 6, 1940). The enclosures indicating the integrated areas have been added.

${ }^{141}$ The Commonwealth \& Southern Corporation, Release No. 76I5 (August I, I 947 ). 


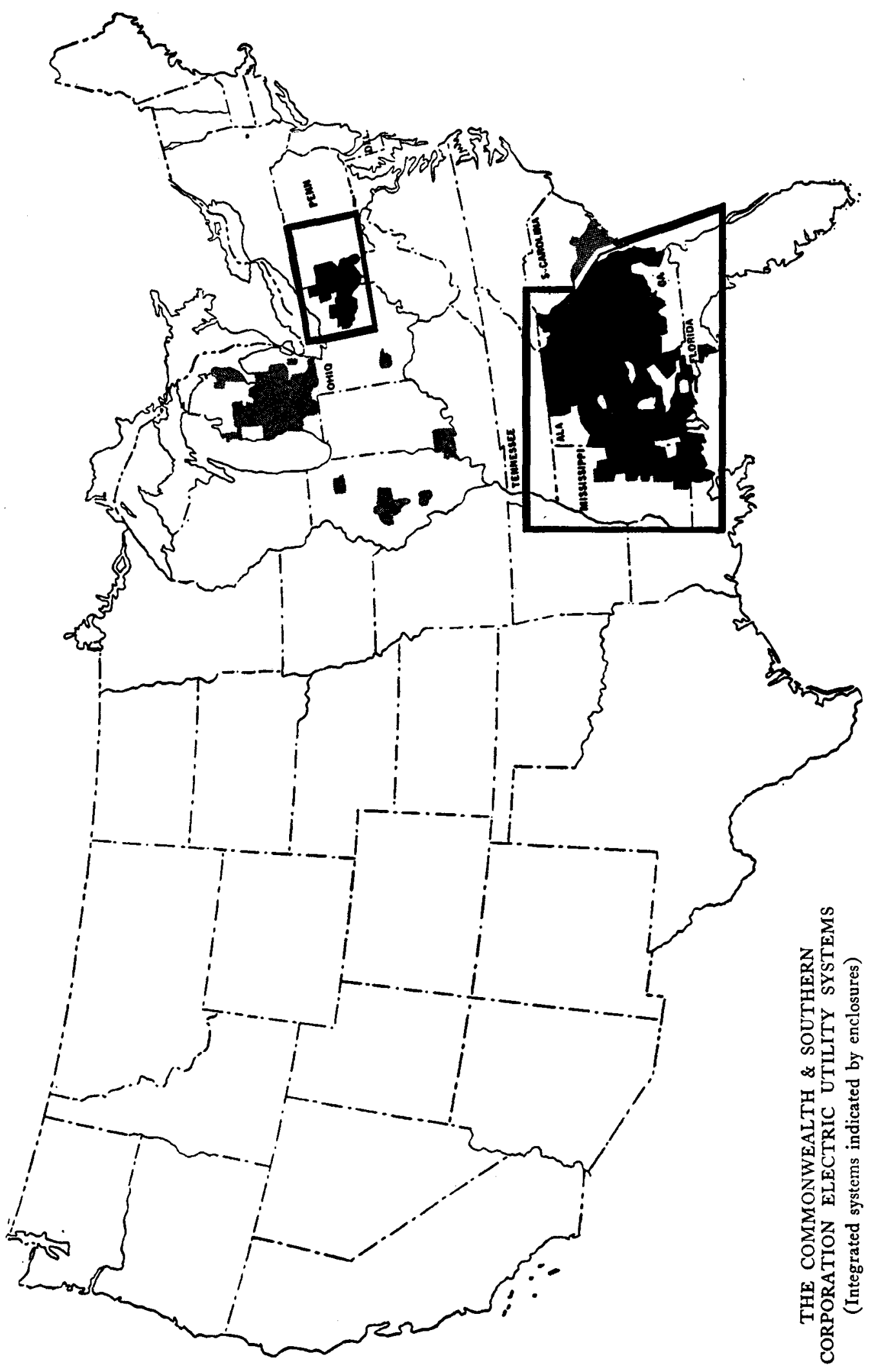


were operated by four different subsidiaries, one in each of these states. The service areas of the four companies were geographically contiguous and their electric facilities were interconnected at various points over heavy duty high voltage electric transmission lines. The Georgia and Alabama companies practically blanketed the states in which they operated. The service areas of the four companies extended 550 miles east and west, and 390 miles north and south.

Pertinent statistics for the four companies combined for the fiscal year 1946 were as follows: ${ }^{142}$

Area served, sq. miles

Population of area served

Customers

Gross property accounts

Net property accounts

Capacity (kw)

Sales (kwh)

Gross electric revenues

Net electric revenues

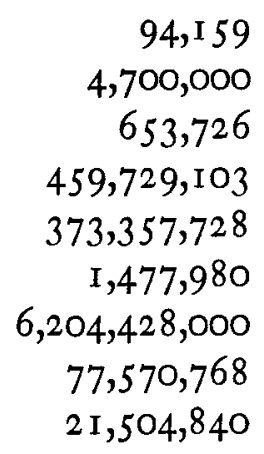

The evidence further showed that the four companies had a history of common planning, development and operation commencing in the middle 1920's. A central load dispatching office in Birmingham, Alabama, had closely coordinated the use of the generating capacity and the power interchange among the companies. Interchanges of electric energy had been substantial. The large size and different types of hydroelectric facilities in Alabama and Georgia required that there be close coordination of such facilities among themselves and with the fuel generating plants in order to achieve maximum generation from the available water supply. There were substantial savings in operating costs and fixed charges resulting

${ }^{242}$ Id. at mimeo. pages 9, 14 and Appendix. Compare with similar statistics for American Gas \& Electric Company at page 89, infra. 
from such coordinated planning and operations. Power supply economies were achieved through sharing of reserve capacity and through joint planning of generating facilities so as to stagger construction and cause facilities to be erected at the sites of cheapest operation irrespective of corporate limits. Further power supply economies resulted from central load dispatching whereby, by the control of reservoirs, run of river and fuel-electric plants, substantial amounts of water which might otherwise be wasted were conserved and thereby the need for additional generating facilities with accompanying fixed charges was averted or delayed. The Commission held that the combination of the electric properties of the four companies constituted an integrated utility system within the meaning of the Act. ${ }^{143}$ It was noted in this decision that the large size of the properties, coupled with the lack of state regulation in Mississippi and Florida, was indicative of the difficulties in attaining the most satisfactory "localized management" and "effectiveness of regulation" in the territory served. The factors of interconnection, coordination, and relatively economic operation outweighed these objections. In effect, therefore, elements (I), (2), and (4)(b) of integration, as listed above, prevailed over elements (3), (4) (a), and (4) (c). The Commission commented upon the marked industrial growth of the territory served by the four companies in recent years, which tended to reduce their comparative economic size. The Commission was of the opinion, however, that this combination of properties approached the maximum size consistent with the standards of localized management, efficient operation, and effectiveness of regulation contained in Sections 2(a)(29)(A) and I I (b) (I).

The properties of The Commonwealth \& Southern Corporation in South Carolina, which adjoined the integrated 4-

${ }^{143} I d$. at mimeo. page 23 . 
state system, were held not to be a part of such integrated system. ${ }^{144}$ The South Carolina properties were physically connected with the Georgia properties and there was a minor interchange of power between the two. However, the Commission was of the opinion that there was lacking the integral operating relationship which Congress intended must exist before the combined properties could be held to be economically operated as a coordinated system; that it was doubtful whether the electric properties of South Carolina were in the same "area or region" as the other four companies; and that the combination of the five groups of properties would be in violation of the size standards of Section $2(\mathrm{a})(29)(\mathrm{A}) .^{145}$

\section{The Middle West Corporation}

The Middle West Corporation controlled a vast utility empire in the central part of the United States. Its subsidiaries operated in fifteen states, and also in Canada and Mexico. ${ }^{146}$ Substantial electric operations were carried on by Middle West in Illinois, Kentucky, Tennessee, and Virginia. The electric properties in Illinois were completely interconnected, and they were also interconnected with the electric

${ }^{144} I d$. at mimeo. page 24 .

15 ".. . We do not, in applying particular size standards, lose sight of the objectives of other criteria. There must be a reconciliation of all objectives to the end of accomplishing a satisfactory administration of the Act. Thus we do not disregard operating efficiency in our determination of whether size is excessive from the view point of localized management or effectiveness of regulation. We have carefully considered the lack of an integral operating relationship between South Carolina Power and the other four companies, as described above. While we have been moved to permit the continuance of the proposed large combination of electric properties under the common control of Southern, in the main so as not to disturb their present and historical coordination and efficiency, there is no such justification for permitting the continued joinder of South Carolina Power." The Commonwealth \& Southern Corporation, Release No. 761 5 (August 1, 1947), mimeo. p. 24.

${ }^{146}$ See map of The Middle West Corporation electric utility systems on page 65. The source of this map is The Middle West Corporation, Release No. 4846 (January 24, I 944). The enclosures indicating the inegrated areas have been added. 
properties in western Kentucky. Power was interchanged among these facilities. The area served was irregular, but extended 300 miles from north to south and 200 miles east to west at its widest point. The Illinois and western Kentucky properties were held to be an integrated system. ${ }^{147}$ The electric properties of Middle West in central and eastern Kentucky, western Virginia, and northeastern Tennessee were interconnected with each other, but not with the Illinois and western Kentucky system. The central and eastern Kentucky, Virginia, and Tennessee properties were held to constitute another integrated electric utility system. ${ }^{148}$ Middle West contended that both of these systems together formed one integrated system. The Commission did not pass upon this contention because it recognized that in the reorganization of the Midland United Company, which blanketed Indiana, Middle West might acquire substantial interests therein, and the larger combination of properties resulting therefrom would materially change the relationship of the Illinois and Kentucky properties.

Wisconsin Power \& Light Company, a Middle West subsidiary operating in southern and central Wisconsin, served an irregular area extending I 90 miles from north to south and 140 miles east to west. With a minor exception, the properties in this area were interconnected. They were found to be a single integrated system. ${ }^{149}$ The properties of Lake Superior District Power Company, another Middle West subsidiary, in northern Wisconsin and upper Michigan were described as an integrated electric utility system, although there was no analysis given of the determinative elements.

Central and South West Utilities, an intermediate holding

${ }^{147}$ The Middle West Corporation, 15 S.E.C. 309, 316 (1944).

${ }^{148}$ Ibid.

${ }^{119}$ Id. at 318 . 
company in the Middle West system, was the parent of Central Power \& Light Company ("Central Power"), West Texas Utilities Company ("West Texas"), Southwestern Light \& Power Company ("Southwestern Light"), Public Service Company of Oklahoma ("Public Service"), Southwestern Gas \& Electric Company ("Southwestern Gas"), Pecos Valley Power \& Light Company ("Pecos Valley"), and Oklahoma Power \& Water Company ("Oklahoma Power"). Middle West contended that all of these properties combined constituted one integrated electric utility system. They formed a huge crescent swinging north from the southern tip of Texas, into Oklahoma, and east and southward into Louisiana and northeastern Texas.

Central Power was an interconnected system covering practically all of south Texas below San Antonio and Houston, extending from the Gulf of Mexico to the western part of Val Verde County, a distance of 350 miles. Its greatest distance north to south was 300 miles. The area served was about one-third the size of Texas, and was sparsely populated. This system was interconnected with that of West Texas at two points, and there was a small interchange of power between the two systems.

West Texas operated an interconnected electric utility system in west central Texas, north of the Central Power area. It served a territory of 42,000 square miles, extending 340 miles north to south and 2 ro miles east to west. This area was also sparsely settled. At the northern end of the West Texas system were two interconnections with Southwestern Light, through which West Texas supplied substantial amounts of power to Southwestern Light.

Southwestern Light, the third link in the chain, was an interconnected electric system serving southwestern Oklahoma. It extended about I 40 miles north to south and I 30 miles east to west. Again, the service area was lightly popu- 
lated. It was connected with Public Service on the east.

Public Service operated in eastern Oklahoma, serving an area 180 miles from north to south and 120 miles east to west. Its main system was interconnected and covered a lightly settled area. In I94I Public Service and Southwestern Light were connected by transmission lines 106 miles long, passing through the area of a non-affiliated company. Because of the load growth of Southwestern Light and the availability of cheaper generation in Public Service, this line was intended as a conveyor for power from east to west.

Southwestern Gas was an electric utility system located in western Arkansas, northeast Texas, and northwest Louisiana. Its main properties extended I 50 miles north to south and 140 miles east to west. Including the isolated Fayetteville properties, the north-south stretch was approximately 350 miles. A transmission line connected the main properties of Southwestern Gas with those of Public Service.

These five companies extended to four states. The managements of these companies were generally separate; each had its own operating staff, and each acted as a self-contained unit. Their dealings with each other were not substantially different from their dealings with non-affiliates. The staff of the Public Utilities Division contended that each of the five companies operated a single integrated system. The Commission concluded that there were two large integrated systems in the group. One consisted of the properties of Southwestern Light, Public Service, and Southwestern Gas; the other consisted of the properties of West Texas and Central Power. ${ }^{150}$ The Commission indicated that it would have "great difficulty" in finding that the combined utility assets of the southwest groups could under normal circumstances be economically operated as a single interconnected

${ }^{150} I d$. at 334 . The division of the southwestern properties is shown by the oroken lines on the map, page 65 . 
and coordinated system. The reasons given were manifold. The various companies were stretched end on end; the transmission lines from one end to the other extended over 1,200 miles, and the properties ranged 800 miles north to south, and 680 miles east to west covering I 75,500 square miles in four states; in the hollow between the south and west Texas properties on one hand, and the Oklahoma and northeast Texas properties on the other were large unaffiliated companies, which effectively separated the ends of the properties. A break in the operating relationship among the companies anywhere along the line would completely isolate all the companies on one side of the break from all on the other side. It appeared that such a break existed at the dividing line between West Texas and Southwestern Light. Studies made of this group of properties in I940, relative to future sources and allocation of power, indicated that the flow of power from West Texas north to Southwestern Light should be minimized in order to achieve the most economical operation. Further, the Commission was of the opinion that the southwestern group as a whole was not confined in its operations to a "single area or region," in view of the large distances and areas covered by these properties. And finally, the Commission could not come to the conclusion that the effectiveness of localized management would not be impaired by a continuance of all of these properties under common control.

The combination of Public Service, Southwestern Light, and Southwestern Gas as one integrated system was accepted with hesitancy by the Commission. Southwestern Light and Public Service, although connected by a transmission line, were separated by unsettled territory under the general control of a non-affiliated company. The answer was, however, that the mere existence of non-affiliated territory lying between parts of a claimed system did not compel the conclusion that the system was not integrated. In this case the interven- 
ing territory was sparsely settled and it appeared highly unlikely that the two service areas would ever be joined into a single compact area. Southwestern Light relied upon Public Service for power that could not be supplied by the intervening nonaffiliated company. Southwestern Gas also relied upon Public Service for power. The economies arising from joint operation of these three companies as a single system were estimated to be about $\$ 4,500,000$ for the period $1942-$ 50. The territory served by the three companies extended 400 miles north to south and 350 miles east to west, an area of 53,350 square miles which was similar throughout, relying largely on oil and other minerals, agriculture, and light industry for its subsistence. The Commission made the following finding:

"... The rendition of satisfactory service in arid and sparsely-settled areas frequently requires the stretching of lines over long distances to connect small population centers with generating facilities strategically placed near suitable water and fuel supplies. In view of these facts we believe that the properties in question lie within a single area or region." ${ }^{151}$

In view of the sparsely-settled area served, the necessity of increased spread to encompass a sufficient number of customers to warrant adequate service, and the difficulty of finding suitable generation sites to serve highly local areas, the Commission further found that the combination of these properties was not so large as to impair (considering the state of the art and the area or region affected) the advantages of localized management, efficient operation, and the effectiveness of regulation.

The Commission also encountered difficulty in reaching its

${ }^{151}$ The Middle West Corporation, 15 S.E.C. 309, 336 (1944). 
decision that the West Texas and Central Power properties were integrated. The problems of these two companies were much the same as those of the three companies to the north, although they were even more aggravated. They covered an area of 120,000 square miles, much greater than the area of Southwestern Light, Public Service, and Southwestern Gas. However, they only served about half as many customers. There was evidence of economies arising from closely coordinated operation and joint planning of the two companies. Because of differences in the timing of agricultural load demands, there was substantial peak diversity as between the two. Applying the reasoning used with reference to the Southwestern group properties to the north, the Commission arrived at the conclusion that the properties of West Texas and Central Power formed one integrated electric utility system. ${ }^{162}$

Middle West was permitted to introduce further evidence to show that all of the southwestern group of properties together constituted a single system, and as a result the decision of the Commission was altered in a subsequent opinion. ${ }^{153}$ The original opinion that there were two systems within this group was principally motivated by the fact that, notwithstanding interconnections, normal operations did not require substantial coordination of both systems. Additional evidence demonstrated that there was substantial operational coordination between the properties of both systems, that this coordination was essential to the internal operations of all companies in each system, and that there would not be a substantial future decrease in the operational coordination

${ }^{152}$ The Middle West Corporation, 15 S.E.C. 309, 339 (1944). Certain properties of West Texas and Central Power were excluded, however. These were the Dalhart and Texline properties of West Texas, and the Big Bend, Zapata, Pleasanton, and Mexican properties of Central Power.

${ }^{155}$ The Middle West Corporation, 18 S.E.C. 296 (1 945 ). 
between the systems and in resulting economies. The assets of Southwestern Light had been acquired by Public Service, and it was shown that there was substantial interchange of power between the new "Western Division" of Public Service and West Texas. The anticipated decreases in such interchange had not occurred. Meanwhile, a central load dispatcher had been appointed who worked in connection with committees composed of representatives of system companies. He had the entire generating system under his control and was able to coordinate the facilities so as to route power from place to place within the system as need and economy dictated. Thus the two requirements of interconnection and economical operation contained in Section 2(a) (29) (A) were met.

The Commission referred to its original decision in connection with the other basic requirements of Section 2(a) (29) (A). ${ }^{154}$ Briefly, they were found to be satisfied by virtue of the sparsely settled and arid region involved and the disadvantages of lack of coordination, in spite of its tremendous size. Consequently, the major electric utility properties of Middle West in the southwestern area were found to be a single integrated system. ${ }^{155}$

It further appeared that interconnection with the Pleasanton area of Central Power was planned as soon as supplies were available, and that such interconnection would result in

${ }^{154}$ The Middle West Corporation, 15 S.E.C. 309 (1944).

${ }^{155}$ The Middle West Corporation, 18 S.E.C. 296 (1945). The Commission said: "In our prior opinion we discussed the size and geophysical conditions of the territory. The territory is a large one. However, as we have noted, it is unique in various respects. Limited supplies of adequate water, small and scattered population localities, the generally dispersed industrial and agricultural locations require relatively high concentrations of generating capacity and long transmission lines. Neither localized management nor efficient operation nor the effectiveness of regulation (considered as relative standards depending for their content on the state of the art, the area or region affected, and the demonstrated disadvantages of lack of coordination) is impaired in the sense which we believe was intended in Section 2 (a) (29)(A) particularly in the light of demonstrated disadvantages of lack of coordination in this case." 18 S.E.C. $296,299$. 
additional economies and increased coordination of the Central Power system. It was therefore found that the Pleasanton properties, previously excluded, were a part of the principal integrated system of which Central Power was a part. ${ }^{156}$

Middle West was not content to let the matter rest here. It will be recalled that the Big Bend electric properties of Central Power were not included in the large integrated system of which Central Power was a part. ${ }^{157}$ These properties served eight communities north and east of the Rio Grande River in West Texas. Power was supplied by diesel generating units for six of these communities, and the other two purchased power from a non-affiliated company. West Texas Utilities Company proposed to acquire all of the Big Bend properties and to interconnect all of them, except those in Presidio, through the construction of approximately 75 miles of transmission line, and to interconnect such properties with the main interconnected electric transmission system of West Texas through the construction of approximately 45 miles of $66 \mathrm{kw}$. line. It was not then planned to interconnect Presidio, which was 50 miles from the nearest system property. West Texas intended to supply the power needs of the Big Bend area from its steam generating station at Girvin, Texas, which had a capacity of $\mathrm{I} 8,000 \mathrm{kw}$, as compared with the $5,000 \mathrm{kw}$. capacity of the diesel plants in the Big Bend area. At the date of the original divestment order, January $24,1944,{ }^{158}$ the Girvin station was used for standby purposes only, due to high fuel oil costs. However, in 1944 a source of natural gas for boiler fuel was located about 20 miles from the Girvin station, and West Texas obtained a ten year contract for the output of the field and constructed a pipeline from the field to the Girvin plant. The fuel costs at the Girvin

\footnotetext{
${ }^{136}$ The Middle West Corporation, 18 S.E.C. 296 (1 945 ).

${ }^{187}$ See footnote 152, supra.

${ }^{138}$ The Middle West Corporation, 15 S.E.C. 309 (1944).
} 
station thus became the cheapest of any station in the West Texas system, and the fuel supply was estimated to be adequate for 15 to 20 years. The cost of generating power in the existing Big Bend diesel plants was about five times the cost of power at the Girvin station. The Big Bend area was the logical market for the output of the Girvin station, owing to its location. The evidence showed that the Big Bend area would receive improved service and reduced rates through the proposed interconnection.

The Big Bend properties extended I ro miles east to west, and 70 miles north to south. However, the same consideration of sparse population, limited supplies of fuel and water, and other factors applied to the Big Bend properties as well as to the main system. The Commission concluded that these properties when connected were a proper part of the larger integrated system of which West Texas was a part. ${ }^{159}$ Even though the Presidio properties were not interconnected with the other Big Bend properties and there was no proposal to make such an interconnection, it appeared that there was no other nearby utility system to which they could be sold and no one was interested in purchasing the property, and therefore the Commission allowed West Texas to acquire and retain them along with the other Big Bend properties. ${ }^{160}$

Middle West further pointed out a change of conditions with reference to the Zapata, Texas, properties, previously held to be non-retainable. ${ }^{161}$ Zapata was 38 miles distant from the nearest properties of Central Power in south Texas. It was 200 miles from any other domestic electric utility com-

${ }^{150}$ West Texas Utilities Company, Release No. 6320 (December 20, 1945).

${ }^{100}$ The only apparent justification for the retention of the Presidio properties, which were not interconnected with those of West Texas and were not shown to be economically capable thereof, was the difficulty of disposing of them. The Commission has often held that this is not a valid reason for permitting the retention of non-integrated properties. See, e.g., Associated Gas \& Electric Corporation, i I S.E.C. I I 5 (1942).

${ }^{161}$ See footnote 152 , supra. 
pany and was served with electric energy by an oil engine generating station. Since the entry of the orginal order of divestment on January $24,1944,{ }^{162}$ Central Power had commenced the construction of its lines toward Urebino, 4 miles north of Zapata. The four-mile extension to Zapata would cost $\$ 6,000$, and Central Power proposed to make such an extension if permitted to retain the Zapata system. The results of such an interconnection would be lower rates to the I 55 Zapata customers and an estimated profit of $\$ 4,784$, instead of a loss of $\$ 2,096$ to Central Power. In view of the characteristics of the territory served by Central Power, described above, the construction of the transmission lines and the other considerations just noted, including the relatively small size of the Zapata properties, the Commission found that Zapata could be retained by Central Power in the larger integrated electric system of which Central Power was a part. ${ }^{163}$

This series of decisions with reference to the southwestern properties of Middle West constitutes the most liberal application and interpretation of Section 2(a)(29)(A) of the Act yet rendered by the Commission. The presentation of the case by the attorneys for Middle West was evidently adroitly handled. The Commission permitted the retention of a chain of properties whose transmission lines extended $I, 200$ miles from one end to the other, almost equal to half the distance across the United States. One set of properties was not interconnected or economically capable thereof. Operations were conducted in four states, Texas, Oklahoma, Arkansas, and Louisiana, and no careful inquiry into the effect of the retention of the entire system on effective state regulation was evident. Localized management was obviously impossible. The principal businesses in the areas served ranged from

${ }^{103}$ The Middle West Corporation, I 5 S.E.C. 309 (1 944 ).

${ }^{163}$ The Middle West Corporation, Release No. 6414 (February 18, 1946). 
coastal shipping, light industry, and dry land farming along the Gulf of Mexico, to irrigated farming along the Rio Grande, to sheep and cattle grazing and the production of petroleum in west Texas, to dry land farming, light industry, and petroleum production in Oklahoma and western Arkansas, to lumbering, light industry, and petroleum in northeast Texas and northwest Louisiana. The principal considerations linking these diversified and distant areas were the fact that all of them were more or less arid, which meant that generating stations were spaced far apart and were required to transmit power over long distances, and the fact that they were sparsely populated. The same argument would be valid with reference to the extension of this system through New Mexico, Arizona, and Southern California. ${ }^{164}$ The Commission would no doubt not permit such a combination of properties, but the Middle West cases do not set forth a rule by which it can be determined when a particular system exceeds the size limitations of the Act. There is no reason to believe that the retention of the southwestern properties of Middle West as a single integrated electric utility system was not, on the whole, a desirable combination; to the contrary, the record indicated that it would benefit investors and consumers alike. The Commission has not always been so generous in its interpretation of the integration provisions of the Act, and for this reason the Middle West cases stand as a landmark of liberality in this respect.

Turning now from the southwestern properties of Middle West, we find that there was still another integrated electric utility system in the empire of Middle West. This was Arkansas-Missouri Power Corporation, located in northeastern Arkansas and southeastern Missouri. Besides the compact and interconnected main operating area, there were two isolated

${ }^{104}$ Cf., Cities Service Power \& Light Company, 14 S.E.C. 28 at 59 (1 943 ). 
service areas to the north in southeastern Missouri. ${ }^{165}$ The area served was about I I,O3O square miles with a population of approximately 71,000 . The Commission held that the main operating area of Arkansas-Missouri constituted a single integrated system, but that the two isolated areas were not a part thereof. ${ }^{166}$

\section{American Gas E Electric Company}

American Gas \& Electric Company was a registered holding company and a subsidiary of Electric Bond \& Share Company, also a registered holding company. The latter owned, at June $30,1945,17.5$ I \% of its outstanding voting securities. However, Electric Bond \& Share had filed a series of plans with the Commission pursuant to Section I I (e) which proposed, among other things, the divestment by it of all its interests in American Gas \& Electric Company. ${ }^{167}$ Therefore, the relation of American Gas \& Electric Company to the remainder of the Electric Bond \& Share Company system will not be considered herein.

As of March I, I945, American Gas \& Electric Company had 23 subsidiaries, of which 12 were electric utility companies operating in the states of Ohio, Indiana, Michigan, Virginia, West Virginia, Kentucky, Tennessee, New Jersey, and Pennsylvania. ${ }^{168}$ The properties of the system were divided into three sectional groups, none of which was interconnected with any other, as follows: (I) the Central System

\footnotetext{
${ }^{205}$ One of them supplied its own power, and the other relied upon purchases from non-affiliates for power.

${ }^{166}$ The Middle West Corporation, 15 S.E.C. 309 ( 1944 ).

${ }^{167}$ Electric Bond \& Share Company, Release No. 5970 (August 3, 1945). Electric Bond \& Share Company proposed to dispose of all of its utility holdings in the United States and to limit itself to its service company and to its foreign subsidiaries.

${ }^{168}$ See map of American Gas \& Electric Company electric utility systems on page 78. The source of this map is Electric Bond and Share Company, 9 S.E.C. 978 (1941). The enclosures indicating the integrated area have been added.
} 


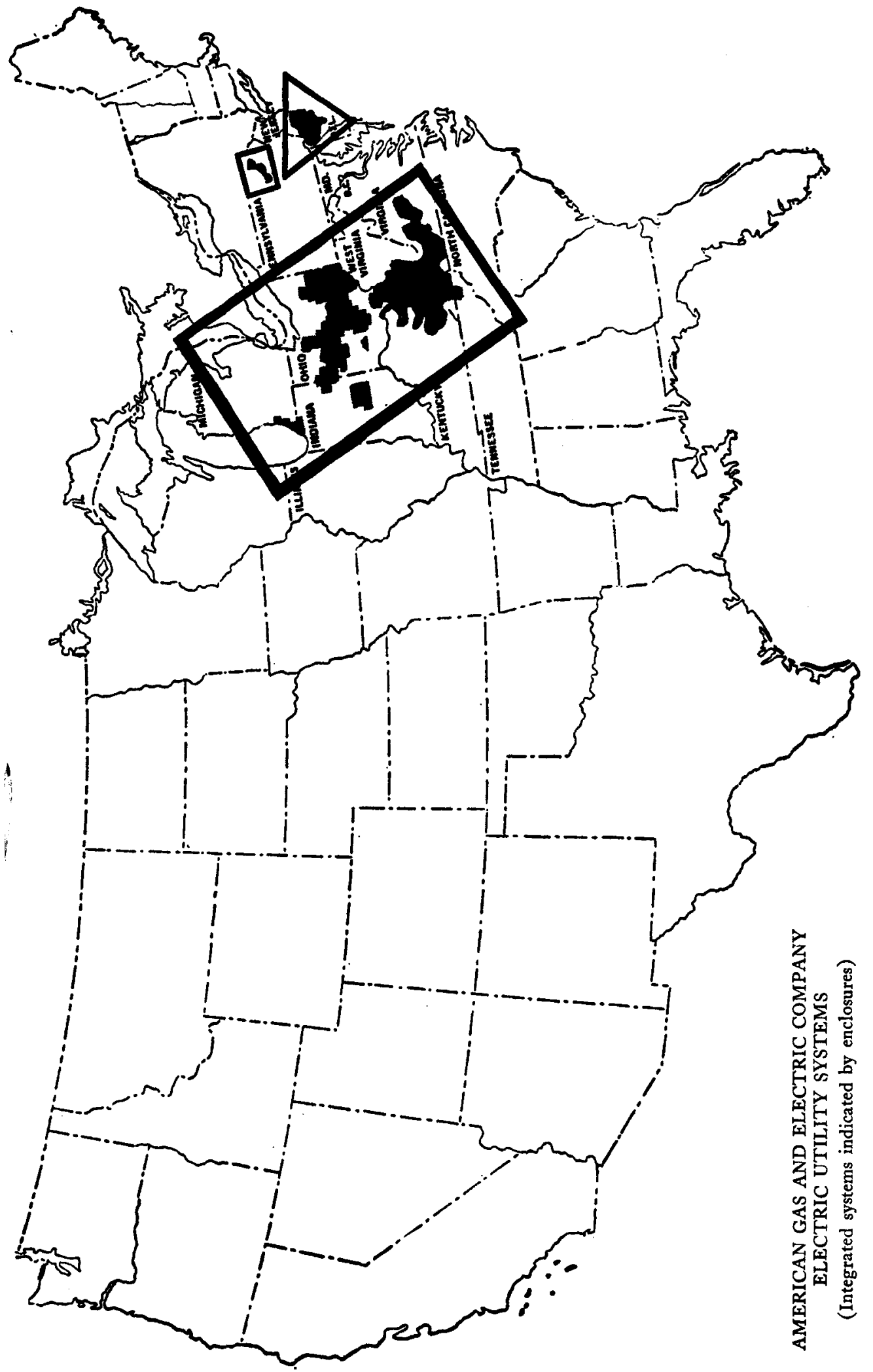


which consisted of utility and nonutility properties operating in the states of Michigan, Indiana, Ohio, Virginia, West Virginia, Tennessee, and Kentucky; (2) the Northeast Pennsylvania System which consisted of utility and nonutility properties in the state of Pennsylvania; (3) the South Jersey System which consisted of utility and nonutility properties in the state of New Jersey.

I. The Central System of American Gas \& Electric Company.

American Gas \& Electric Company indicated that the Central System was its principal integrated system under Section I I (b) (r). This was an obvious choice, as this system embraced $85.67 \%$ of the consolidated gross utility plant accounts of American Gas \& Electric Company, and produced $85.29 \%$ of the consolidated gross operating revenues of the company. ${ }^{189}$

The extremities of the Central System as of January, 1945, were as follows: Benton Harbor, Michigan, at the northwest end; Steubenville, Ohio, on the northeast; the North Carolina-Tennessee state line near Newport, Tennessee, on the southwest; and the Virginia-North Carolina state line near Danville, Virginia, on the southeast end. The area encompassed within the termini of the system's high voltage transmission lines was approximately 90,000 square miles. The population of the area served was $3,018,000$. The system companies did not, however, sell electricity at retail throughout the entire area and a number of other important electric utility companies operated in the territory. The system was completely interconnected. There were substantial and frequent power interchanges between the Central System companies, and their operation as a single system was shown

\footnotetext{
${ }^{169}$ American Gas \& Electric Company, Release No. 6333 (December 26, 1945), mimeo. p. 5 .
} 
to be economical. The electric utility companies comprising the Central System were subject in varying degrees to regulation by the commissions of the various states in which they operated and were also subject to the jurisdiction of the Federal Power Commission. The Commission held that the Central System constituted a single integrated electric utility system, making these observations:

"The size and extensive area of the utility operations of the Central System, as previously described, present in serious form the question whether we can approve it as retainable in its entirety by $A G \& E$. The Central System, however, has a long historical record of having been planned, developed, and operated as a highly coordinated system under AG\&E's control. Moreover, it does not appear to be so large in any of the states in which it operates as to impair the effectiveness of regulation. We note also that we are not being asked to approve the creation of a new holding company over the Central System but merely to determine whether, pursuant to the provisions of Section I I (b) (I), the status quo is required to be affected. In the instant case, the relatively high degree of coordination of the system's utility facilities and their relatively economical operation, which, in part, appeared to be due to common control, and the other factors noted above, have led us to conclude that the system, as presently constituted, constitutes a single integrated utility system within the meaning of Section 2(a) (29)(A) of the Act. . . . We are of the opinion, however, that the Central System approaches the maximum size which we believe is consistent with the standards of localized management, efficient operation and effectiveness of regulation contained in Sections 2(a) (29) and I I (b) (I)."170

${ }^{170}$ American Gas \& Electric Company, Release No. 6333 (December 26, 1945), mimeo. pp. 2 1-22. 
The above comments with regard to the size of the Central System returned to plague American Gas \& Electric Company at a shortly later date. American Gas \& Electric Company made application with the Commission for permission to bid on the purchase of $99 \%$ of the common stock of Columbus \& Southern Ohio Electric Company, an electric utility company operating in Ohio, from a subsidiary of United Light \& Railways Company. ${ }^{171}$ Columbus \& Southern Ohio served a total area of 9,800 square miles with a population of 450,000 , of which 168,000 were electric customers. Its service area lay in the south central portion of Ohio, and was contiguous with that of The Ohio Power Company, one of the major companies in the Central System of American Gas \& Electric Company. The lines of the two companies were interconnected. American Gas \& Electric Company proposed, if the acquisition were approved, to spend over $\$ 9,000$, 000 to rehabilitate the Columbus \& Southern Ohio system and to integrate it with the Central System. The major item of rehabilitation proposed was a transmission ring around the city of Columbus to strengthen and improve service to that city, and the major items of coordination involved the addition of high tension interconnections between Columbus \& Southern Ohio and Ohio Power facilities. Substantial improvements in the quality of service and substantial savings, both capital and operating, amounting to $\$ \mathrm{I}, 505$, O I 5 per year, were claimed as the probable result of the program. The Commission assumed that some such savings would occur, but did not accede to the total amount.

${ }^{171}$ American Gas \& Electric Company, Release No. 6639 (May 1 7, 1946). Such application was subject to the requirements of Section io (c) (z) of the Act, which provides that "the commission shall not approve ... the acquisition of securities or utility assets of a public-utility or holding company unless the Commission finds that such acquisition will serve the public interest by tending towards the economical and efficient development of an integrated public-utility system. ..." Therefore, the question of the integration of the Columbus \& Southern Ohio properties with those of the Central System was raised. 
In the opinion of the Commission the size requirements of Section 2(a) (29) (A) presented an insurmountable barrier to the proposed acquisition. ${ }^{172}$ Although the area served would not have been increased by the proposed combination, the total population served would have been increased $19.2 \%$, customers increased $21.4 \%$, gross electric revenues increased I $4.1 \%$, electric utility plant increased $12.9 \%$ and miles of line increased $17.9 \%$. The conclusion of the Commission was that the acquisition of Columbus \& Southern Ohio would not be merely the addition of a spur or connecting link to the system, but would represent a major extension into new territory which very materially and substantially enlarged the system. It therefore took the system beyond the maximum limit permissible under Section I I (b) (r) ${ }^{173}$ A further consideration was the fact that the Central System, by itself, was increasing its load $5 \%$ each year, and therefore the additional properties would increase the normal growth of load proportionately. The essence of the decision was that the combination of these properties could not be found to be "not so large as to impair . . . the advantages of localized management and the effectiveness of regulation."

${ }^{172}$ In American Gas \& Electric Company, Release No. 6639 (May 17, I 946), at mimeo. pp. 6-7, the Commission stated: "It is not an accident of rhetoric that size is made an independent factor in this legislation. The Congress regarded localization of operations, per se, as an important aim to be achieved in this legislation. The Senate Report, for example, said: 'An operating system whose management is confined in its interests, its energies, and its profits to the needs, the problems, and the service of one regional community is likely to serve that community better, to confine itself to the operating business, to be amenable to local regulation, to be attuned and responsible to the fair demands of the public, and more often, to get along with the public to mutual advantage . . . and essentially local enterprise is far less likely to accumulate a disproportionate amount of political and economic power.' (Report of the Committee on Interstate Commerce, 74 Cong., Ist Sess., Rep. No. 621, May 13, 1935, p. 12). See too, The North American Company, i I S.E.C. I 94 (1942)."

${ }_{173}$ The Commission here pointed out that the requirements of Section $\mathrm{ro}(\mathrm{c})$ of the Act are even more rigorous than those of Section I (b) (I). American Gas \& Electric Company, Release No. 6639 (May 17, 1946), mimeo. p. 9. See discussion of this subject at Pp. 3I-33, supra. 
In answer to the assertion of American Gas \& Electric Company that the proposed acquisition would result in substantial savings and increased efficiency, the Commission pointed out that such benefits were not entirely dependent upon joint ownership of the properties, citing the history of certain power pools by independent companies during the war and previously. It was noted that Columbus \& Southern Ohio was not a small company, unable to operate effectively and finance a sound utility system by itself. And the concentration of control of the proposed enlargement at the executive offices of American Gas \& Electric Company in New York City was also decried. The Commission took the position that the estimates of savings and economies presented by the company should be offset by some indeterminate amount arising out of the disadvantages inherent in absentee management of vast utility empires. ${ }^{174}$

The majority opinion in the Columbus \& Southern Ohio case was rendered by Chairman Purcell and Commissioner McConnaughey. Commissioner Healy did not participate, and Commissioner Caffrey dissented. ${ }^{175}$ The latter was impressed by evidence of annual capital and operating savings of at least $\$ \mathrm{I}, 500,000$, estimated to arise from the proposed combination. His argument was twofold: first, the proposed acquisition would not carry the Central System into any essentially new territory, as the Central System already embraced the area served by Columbus and Southern Ohio; and second, he contended that the "size" standard of Section 2(a) (29) did not exist in a vacuum, but should be considered in the light of the state of the art and with especial reference to impairment of the advantages of localized management,

${ }^{174}$ See Cities Service Power \& Light Company, I 4 S.E.C. 28 ( 1943 ).

${ }^{176}$ American Gas \& Electric Company, Release No. 6639 (May 17, 1946), mimeo. p. 14. 
efficient operation, and effective regulation. The Commissioner pointed out that "localized management" does not mean complete neighborhood control; that the Central System had been held not to impair the advantages of such management, and the coordination into the system of properties lying within its general territory had no perceptible tendency to impair those advantages as they then existed. It might possibly have augmented such advantages, since the evidence indicated that within the American Gas \& Electric Company system a high degree of discretion in the handling of purely local problems of relationships with local communities was left to district management and that participation of local management in general community affairs was encouraged by the system. Commissioner Caffrey did not dwell on the question of "efficient operation," as he believed ample evidence had been adduced to prove that the proposed acquisition would enhance efficiency of operations in the Central System. And finally, he did not believe that the combination of these properties would be so large as to impair the "effectiveness of regulation." The Commission would retain its jurisdiction over both sets of properties; the Central System would remain subject to the jurisdiction of the Federal Power Commission, and Columbus \& Southern Ohio would become subject to such jurisdiction. The Ohio State Commission would retain the full measure of its jurisdiction over both Columbus $\&$ Southern Ohio and Ohio Power. The latter commission had, in fact, stated that it deemed the acquisition advisable. The dissenting Commissioner's argument was summed up as follows:

"I believe the principal fallacy involved in the majority's approach is that it tends to assume that the standard relating to the advantages of localized management has a significance independent of the other standards. From my point of view of the past administration 
of the integration provisions of the Act, it is clear that the Commission has always weighed that standard together with the other standards. It has permitted the retention as a single integrated system of properties stretching over vast areas in the States of Texas, Oklahoma, Arkansas and Louisiana because it believed the geographical necessities of the territory required that such a conclusion be reached. It has sanctioned the retention in compact areas of large aggregates of utility properties serving essentially urban communities. It has, in fact, sanctioned the joint retention of all the companies in $A G \& E$ 's Central system, even though those companies operate in a vast area stretching over 90,000 square miles. (The Middle West Corporation, et al., - S.E.C. - Holding Company Act Release 5606 (1944); The North American Company, et al., II S.E.C. 194 (1942); American Gas \& Electric Company, - S.E.C. - ( 1945), Holding Company Act Release 6333.)

"In each of these cases, size, per se, was not considered as a limiting factor on retainable properties, and in none of these cases was size regarded as a limiting factor in considering the standard relating to the advantages of localized management. Unless the Commission has abandoned the spirit of approach inherent in its past decisions and is now affirming that the standard of localized management is to be considered independently of other incontrovertible and manifest physical and operational advantages, there is no reason why, in my opinion, this application cannot be approved."176

Considering the overlapping territories involved, the favorable evidence as to the degree of coordination and the extent of the benefits resulting therefrom, all placed upon

${ }^{176}$ American Gas \& Electric Company, Release No. 6639 (May 17, 1946), mimeo. p. 16. 
the background of the Middle West and Commonwealth \& Southern cases discussed above, it would seem that the dissent had the better of the argument.

The Commission subsequently relented to a certain extent. American Gas \& Electric Company filed an application relative to the purchase of the stock of Indiana Service Corporation from Midland Utilities Company, a non-affiliate. Indiana Service was an electric utility company operating in northern, central, and northeastern Indiana, including the City of Fort Wayne, where it operated in competition with a municipallyowned electric utility. The company served a total area of about 1,600 square miles with a population of 200,000 , including 28,47 I customers. It was interconnected with Indiana \& Michigan Electric Company, a Central System subsidiary, from which it obtained $75 \%$ of its power. The service area of Indiana Service, with the exception of a spur extending westward along the Wabash River, was flanked on the north, northeast, and south by contiguous service areas of Indiana \& Michigan, there being substantially no gaps in the total area served by both companies. The facilities of the two companies were physically connected and coordinated, and the evidence showed that further interconnections would result in improved and more economical service for the entire area served by the companies.

The Commission differentiated this proposal from the Columbus \& Southern Ohio case on the ground that the acquisition of Indiana Service would increase the size of the Central System only minutely. For example, the area served by Indiana Service was $5.2 \%$ of that served by the Central System, while that of Columbus \& Southern Ohio was $18.5 \%$; populations served were $6.4 \%$ and $19.2 \%$, respectively; customers were $3.6 \%$ and $2 \mathrm{I} .4 \%$, respectively; utility plant accounts were $2.8 \%$ and $\mathrm{I} 2.9 \%$, respectively; and gross 
revenues were $4.9 \%$ and $14.1 \%$, respectively. ${ }^{177}$ It is difficult to see how this acquisition could be considered minute from the above data, but at least it was substantially smaller than the one previously proposed. At any rate, the Commission found that the acquisition of Indiana Service was not so large as to make the resultant size of the Central System a controlling obstacle, and the acquisition was approved under Section 10 of the Act. ${ }^{178}$

American Gas \& Electric Company was given permission to enlarge its Central System further. United Public Utilities Corporation proposed to sell to American Gas \& Electric Company the shares of common stocks of ten electric and gas utility subsidiaries operating in Indiana and Ohio owned by it. The extent of the operations of these ten companies was not given in the opinion and was no doubt small. American agreed to divest itself of the gas utilities, and proposed to operate the electric utilities as part of its integrated Central System. The proposed acquisition was approved under Section IO(c) (2) of the Act. ${ }^{179}$

The Central System of American Gas \& Electric Company was again enlarged by the addition of the electric properties of Central Ohio Light \& Power Company. The Commission approved the acquisition of the stock of the latter company by American Gas \& Electric Company under Section ro(c) of the Act. ${ }^{180}$ Central Ohio was engaged in the generation,

${ }^{177}$ Midland Utilities Company, Release No. 7054 (December I 3, 1946), mimeo. p. 46 . The total square miles served by the Central System unaccountably dropped from the previous estimate of 91,650 in American Gas \& Electric Company, Release No. $66_{39}$, to 30,770 in this release, while the area of Columbus \& Southern Ohio climbed from 2,325 square miles to 5,700. Examination of the map of the American Gas \& Electric Company system, p. 78, indicates that the 91,650 figure is probably correct.

${ }_{178}$ Midland Utilities Company, Release No. 7054 (December 1 3, 1946 ). 1947 ).

${ }^{179}$ American Gas \& Electric Company, Release No. 7915 (December 1o, 1950).

American Gas \& Electric Company, Release No. 10294 (December 19, 
transmission, distribution, and sale of electric energy in Ohio. The territory served by it was divided into two geographical divisions roo miles apart, which were not interconnected. Principal operations in the western division centered about the city of Findlay, with a population of about 20,000. The eastern division centered about the city of Wooster, with a population of I I ,500. Electric service was rendered to 23,679 customers in 19 municipalities and 21 unincorporated communities. The gross utility plant of Central Ohio as of August $3 \mathrm{I}, \mathrm{I} 950$, amounted to $\$ \mathrm{I} 2,588,577$. Operating revenues for the year ended August 3I, I950, were $\$ 4,086,66$ I. Central Ohio generated all of its electric energy requirements for its western division and it was not interconnected with the American Gas system. However, its service area was contiguous to the service area of a subsidiary of American Gas. Central Ohio had no generating facilities in its eastern division and purchased all of its requirements from a non-affiliate. The service area of this division was contiguous on the south to a subsidiary of American Gas. Both divisions were capable of being physically interconnected with the American Gas System. It was estimated that gross savings in power supply for both divisions of Central Ohio resulting from interconnection would reach $\$ 840$,000 by I953, and further economies amounting to $\$ 250$,000 would be achieved by complete coordination of the operating staffs and personnel of the two companies. With reference to the size requirements of Section 2 (a) (29) (A) the Commission pointed out that the acquisition would result in a relatively minor increase in the size of the American Gas System. The percentage increases involved in this acquisition are shown by the following table, which also sets forth the percentage increases contemplated in the Indiana Service Corporation and the Columbus \& Southern Ohio Electric Company proposals: ${ }^{181}$

${ }^{181}$ Ibid., mimeo. pages 1 2-13. 


\begin{tabular}{lllc}
\multicolumn{1}{c}{ Item } & $\begin{array}{c}\text { Central } \\
\text { Ohio }\end{array}$ & $\begin{array}{c}\text { Indiana } \\
\text { Service }\end{array}$ & $\begin{array}{c}\text { Columbus \& } \\
\text { Southern }\end{array}$ \\
Gross Plant & $1.9 \%$ & $2.8 \%$ & $12.9 \%$ \\
Revenues & 2.6 & 4.9 & 14.1 \\
Total kwh Sales & 2.0 & 4.2 & 8.1 \\
Customers & 2.1 & 3.6 & 21.4 \\
Net Dependable & & & \\
$\quad$ Capacity & 2.3 & 1.7 & 1 1.6 \\
Peak Load & 2.1 & 4.9 & - \\
Pole Miles of Line & 1.5 & 6.4 & 19.9 \\
Population Served & 1.9 & 5.4 & 18.2 \\
Communities Served & 1.9 & 5.2 & 18.5 \\
Area Served & - & &
\end{tabular}

The Commission thus sanctioned the continuation of the Central System of American Gas \& Electric Company as a single integrated electric utility system. It is the largest of such systems yet defined, except for total square miles of area served. ${ }^{182}$ The following statistics for the year I 950 relative to the Central System, including the Indiana Service Corporation, Central Ohio, and United Public Utilities Corporation properties, indicate the gigantic scope of its operations: ${ }^{183}$

Population Served

Line Miles

$$
4,095,000
$$

Customers

Gross Plant Account

59,7 I 2

Capacity (kw)

Sales (kwh)

Gross Revenue

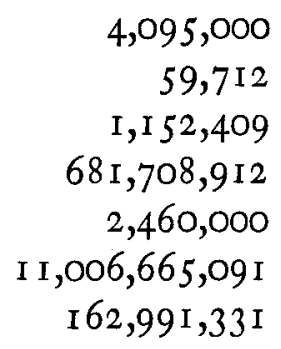

As Commissioner Caffrey has observed, it would appear to be obvious that size, per se, is not a limiting factor in the determination of what constitutes an integrated electric utility system.

${ }^{182}$ This distinction belongs to the Southwestern properties of Middle West, as has been shown above.

${ }^{188}$ American Gas \& Electric Company, Release No. 10294 (December I9, 1950), mimeo. p. 13. Compare similar figures for the southern properties of The Commonwealth \& Southern Corporation, page 62, supra. 
2. The Northeast Pennsylvania System of American Gas \& Electric Company

American Gas \& Electric Company was also the parent company of The Scranton Electric Company, which operated an electric utility system in northeast Pennsylvania. ${ }^{184}$ The population served amounted to 344,000 , including 78,469 electric customers in 57 communities. This system was 240 miles away from the nearest extremity of the Central System, and was not interconnected therewith. It was held to be a separate integrated electric utility system. ${ }^{185}$

3. The South Jersey System of American Gas \& Electric Company

Electric operations were carried on by subsidiaries of American Gas \& Electric Company in southern New Jersey. Electric service was rendered to 225 communities having a population of 308,000 , of which 104,805 were customers. The operations of the company were subject to the jurisdiction of the Board of Public Utility Commissioners of the State of New Jersey. Although completely interconnected within itself, this system was not interconnected with either of the other two American electric systems, nor was it capable of such interconnection. It was held to constitute a single integrated utility system. ${ }^{186}$

\section{General Public Utilities Corporation}

The most recent integration decision of the Commission concerned the system of General Public Utilities Corporation ("GPU"), successor to Associated Gas \& Electric Company. GPU contended that the electric properties of its subsidiaries Pennsylvania Electric Company ("Penelec"),

${ }^{184}$ See map, page 78 . I 945 ).

${ }^{135}$ American Gas \& Electric Company, Release No. 6333 (December 26, ${ }^{186}$ Ibid. 
Metropolitan Edison Company ("Meted"), New Jersey Power \& Light Company ("NJP \& L"), and Jersey Central Power \& Light Company, the Penn-Jersey System, constituted an integrated electric utility system retainable as its principal system.

The Penn-Jersey System covered the midwestern and southeastern portions of Pennsylvania and the northwestern and east central portions of New Jersey. ${ }^{187}$ At its extremities it extended in an east-west direction from the Ohio-Pennsylvania boundary line to the New Jersey coast line, approximately 375 miles; and in a north-south direction it extended from Lake Erie to below the Maryland-Pennsylvania boundary line, a distance of $\mathrm{I} 85$ miles. The service area of Penelec at its southeastern boundary was contiguous with that of Meted at its southwestern boundary for a distance of eight miles. Adjacent to Meted's eastern service area but separated by the Delaware River was the service area of NJP \& L located in the northwestern part of New Jersey. Adjacent to the eastern boundary line of NJP \& L's service area was the electric service area of Jersey Central's northern division.

The combined gross electric property account, at original cost, of the companies in the Penn-Jersey System as at December $3 \mathrm{I}, \mathrm{1950}$, totaled $\$ 384,000,000$, and the consolidated electric operating revenues of such companies for the calendar year 1950 aggregated about $\$$ IOI,000,000. The electric territory served covered approximately i 9,650 square miles, having an estimated population of $2,700,000$. At the end of I 950 some 770,000 electric customers were served by the system.

Prior to July 2, 1950, the electric properties of Penelec were not interconnected with the electric properties of the other companies in the Penn-Jersey System. The properties

${ }^{187}$ Omitted from the Penn-Jersey system was the system of Northern Pennsylvania Power Company, another GPU subsidiary, operating in the northeastern portion of the State of Pennsylvania. 
of Meted, NJP \& L, and Jersey Central were also interconnected among themselves. The properties of the latter three companies were known as the "ME-NJ-JC System." The electric properties of Penelec were operated as a separate system, with a central load dispatcher located at Johnstown, Pennsylvania; and the electric properties of the ME-NJ-JC System were operated together as a single system, with a central load dispatcher located at Reading, Pennsylvania. On July 2, 1950, the transmission system of Penelec was interconnected with that of ME-NJ-JC by means of a 29 mile line which was subsequently increased in capacity to 60,000 $\mathrm{kw}$. In addition, central load dispatching for the entire PennJersey System was transferred to Reading. GPU estimated that the net annual savings from the installation of this interconnection would average $\$ 150,000$. After July 2, 1950, the ME-NJ-JC and Penelec systems were operated together on a coordinated basis.

GPU was obliged to revise its expansion plans because of the greatly increased demand for power arising after the outbreak of the Korean conflict. It was estimated by GPU that annual savings totaling $\$ 3,235,000$ would result from its revised expansion plans for the consolidated systems as follows: \$I, I 30,000 in coal costs; $\$ 990,000$ in construction costs; $\$ 430,000$ from greater efficiency in the use of fuel; and $\$ 685,000$ in labor and maintenance costs for the larger size generating units. From this amount there was deducted $\$ 495$,000 to cover annual fixed charges on the new transmission line which was contemplated in the plans, leaving estimated net annual savings of $\$ 2,740,000$. The Commission was of the opinion that the foregoing estimates of savings were overstated, except for the item of coal costs. However, it was convinced that the properties of the Penn-Jersey System would be efficiently operated in a fully coordinated manner so as to produce substantial savings. It was indicated that 
the electric properties of NJP \& $\mathrm{L}$ and Jersey Central were under the jurisdiction of the state public utility board of New Jersey and that the electric properties of Meted and Penelec were under the jurisdiction of the Pennsylvania Public Utility Commission. Finally, it was noted that this combined system did not appear to be so large as to impair the advantages of localized management, efficient operation, and the effectiveness of regulation. The Commission therefore found that the Penn-Jersey System was a single integrated electric utility system within the definition of Section 2(a)(29)(A) of the Act and retainable by GPU under Section I I (b)(I) ${ }^{188}$ The Commission further found that the electric properties of GPU subsidiary Northern Pennsylvania Power Company and its subsidiary, The Waverly Electric Light \& Power Company, which served north-central and northeastern Pennsylvania and Waverly, New York, were not economically capable of physical interconnection with the Penn-Jersey System and could therefore not be included as part of the latter system. ${ }^{189}$

\section{Summary of Electric Utility Integration}

From this survey of the decisions defining integrated electric utility systems under the Act may be drawn a number of important conclusions. In the first place, the primary requisite of such a system is physical interconnection or economical capability of such interconnection. This was indicated in the hearings held before the proposed Public Utility Holding Company Act became law and is amply demonstrated in the foregoing cases. ${ }^{190}$ In most instances the other integrational factors seem to follow as a matter of course, if the properties under consideration are interconnected. In the

${ }^{1 \$ 8}$ General Public Utilities Corporation, Release No. 10982 (December 28, 1951 ).

I 1 bid.

${ }^{100}$ House Hearings on H. R. 5423, 74th Congress, Ist Sess., p. 1572 (1935). 
second place, it appears that the application of the Act has expanded with technological advances in electrical interconnection. At the date of enactment of this law the maximum distance for the transmission of large quantities of power was 300 miles, and the average distance that electricity moved was I 8 to 25 miles. ${ }^{191}$ It has been shown that in the southwestern system of the Middle West Corporation transmission lines extended from one end of a I,200 mile system to the other. Ten years after the passage of the Act this system was held to be integrated, although power was being transmitted four times the maximum distance of I935. Third, even though electric systems may be physically interconnected, such interconnections must be employed to effect substantial interchanges of power. The proof of such interchanges became the determinative factor in the case of the southwestern system of Middle West, whereas the lack of such proof defeated the contentions of Cities Service Power \& Light Company with reference to the overall integration of its Rocky Mountain group of properties. The presence of a central load dispatcher for such a combination of systems is another important factor tending to prove the required element of economical operation as a single interconnected and coordinated system. This requirement contemplates operational coordination, and coordination of corporate management is not enough. Fourth, the decisions are conflicting as to whether size, per se, is a limiting factor. Systems ranging in geographical size from about one square mile to 175,500 square miles have been held to be integrated. The decision in the American Gas \& Electric Company-Columbus \& Southern Ohio Electric Company case indicates that size alone is one of the tests that must be met in order for a system to be integrated. The holding in the case of the Rocky Mountain

${ }^{191}$ House Hearings on H. R. 5423, 74th Congress, ist Sess., pp. 270, 915 and 2225 (1935). However, technological advances in this field were predicted. $I d$. at pp. 1917-1918. 
properties of Cities Service Power \& Light Company is similar. On the other hand, there is the decision in The Middle West Corporation case relative to its southwestern properties. This case obviously considered the size of the system only in connection with the other tests for integration and subordinated size to such other tests. A less exaggerated example of the application of this rule appears in The Commonwealth \& Southern Corporation case. The conflicting interpretations were carefully considered in the dissent to the Columbus \& Southern Ohio case and the conclusion was reached by Commissioner Caffrey that size alone is not a limiting factor. This appears to be the sounder interpretation of the two. Fifth, the factors of localized management, efficient operation, and effective regulation are often glossed over, except in the cases of very large systems. If economical operation as a single interconnected and coordinated system is proved, then efficient operation is generally assumed. As to local regulation, the Commission does not inquire closely into the degree of effectiveness of such regulation and is satisfied even when the system under consideration spreads across several states with varying degrees of regulation in each. More attention is paid to localized management. The Commission appears particularly to dislike absentee management in a financial center, such as New York City, for a far-flung utility empire. It favors a high degree of local control over each operating utility. However, it is obvious that this objective cannot be attained by some of the larger systems which have been permitted to survive.

\section{Integration as Applied to Particular Gas Utility Systems}

An integrated gas utility system is defined in much the same manner as an integrated electric utility system, except that the requirement of interconnection is omitted. This is of 
course due to the nature of the manufactured gas business, where the gas is transmitted for only short distances. ${ }^{192}$ Under the provisions of Section 2(a) (29) (B) of the Act the basic essentials of an integrated gas utility system are as follows:

(I) Companies so located and related that substantial economies may be effectuated by their being operated as a single coordinated system;

(2) Such system to be confined in its operations to a single area or region, in one or more states; provided, however, that gas utility companies deriving natural gas from a common source of supply may be deemed to be included in a single area or region; ${ }^{193}$

${ }^{102}$ See House Hearings on H. R. 5423, 74th Congress, Ist Sess., p. 802 (1935). It is cheaper to build another plant than to pipe manufactured gas for long distances.

${ }^{103}$ The bill in its original form made no provision for natural gas utility companies. The latter contended that natural gas has to be taken where it exists in the earth and transmitted from there to population centers for consumption, and that they therefore could not confine their operations to a single area or region. House Hearings on H. R. 5423, 74th Congress, ist Sess., pp. 1710 , 1 746-1 747 (1935); Senate Hearings on S. 1725, 74th Congress, Ist Sess., pp. $148,673,947,949$, and 958 (1935). In the House Hearings, p. 2280, the Electric Bond \& Share Company argued as follows:

"It is submitted that few, if any, natural gas systems could be grouped according to this conception. While the place of discovery and production of natural gas is limited by nature, the place of delivery and use is limited only by the state of the art of transmission, and it is in the public interest to extend the service as far as it may be done on a basis which is financially and economically sound. At the present time, for example, gas is being carried by one of the systems in the natural gas industry more than 1000 miles across 6 states from the Amarillo field in Texas to the Chicago markets and to many intervening markets. The conception of 'economically integrated' may be applied to such a system but it does not seem possible to apply to it the conception of 'geographically integrated.' Since natural gas must go by continuous movement and operation of facilities from the reservoir underground in the field to the burner tips in the home where it is used, it is obvious that such a system could not be broken up, merged with other natural gas lines, and operated as parts of the newly constituted geographical or regional units.

". . . It is submitted that a serious attempt to graft such a conception of a theoretical grouping on the natural gas industry would inevitably bring the industry into a general state of demoralization, wreck the value of operating company as well as holding company securities, impair service, increase rates to existing customers, and retard further extensions of service." 
(3) Not so large as to impair the advantages of (a) localized management, (b) efficient operation, and (c) the effectiveness of regulation.

The application of these requirements by the Commission is demonstrated in the subsequent cases.

\section{Engineers Public Service Company}

A subsidiary of Engineers Public Service Company, Virginia Electric \& Power Company, operated a gas manufacturing and distribution system in Norfolk, Virginia, serving an area of approximately 35 square miles. ${ }^{194}$ The system furnished gas to 29,363 customers out of a total population of I 57,000 persons in the area served, and was the second largest gas system in the state serving retail customers. This system was held to be an integrated gas utility system within the meaning of Section 2(a) (29)(B) of the Act. ${ }^{195}$ Another Engineers subsidiary, Gulf States Utilities Company, distributed natural gas to customers in Baton Rouge, Louisiana, and environs, a territory of about I 5 square miles in area, with a population of 70,000 , of which 12,542 were customers. Gulf purchased its gas from a non-affiliated company. This system was also held to be integrated. ${ }^{196}$

\section{Standard Power E Light Corporation}

The gas operations of Philadelphia Company, a subsidiary of Standard Power \& Light Corporation, were conducted prin-

The bills were accordingly amended to include the proviso relative to gas utility companies deriving natural gas from a common source of supply, and it became part of the law.

${ }^{194}$ The problem of large geographical size, so apparent in the cases of the electric utility systems previously discussed, is noticeably absent in the case of manufactured gas systems, such as that of Virginia Electric and Power Company.

${ }_{108}$ Engineers Public Service Company, I2 S.E.C. 4 I (1942).

${ }^{136}$ Ibid. 
cipally by three companies. Kentucky West Virginia Gas Company was a natural gas producing company operating in eastern Kentucky. It sold the major portion of its output to Pittsburgh \& West Virginia Gas Company, which operated in West Virginia as a transmission company and supplied natural gas to its subsidiary, Equitable Gas Company. Equitable was the primary distributing company of the system and distributed natural gas at retail in the Pittsburgh area. In addition, Equitable operated certain production, transmission and distribution facilities owned by Philadelphia Company and leased to Equitable. Equitable served 200,000 customers in an area with an aggregate population of about $\mathrm{I}, 500,000$. Obviously, the three companies were interconnected, and most of the gas used by these companies was obtained from common sources of supply. Pittsburgh \& West Virginia Gas Company was subject to regulation by the West Virginia Public Service Commission and the Federal Power Commission; Equitable was subject to regulation by the Pennsylvania Public Utility Commission; Philadelphia Company was not subject to regulation by the Pennsylvania Public Utility Commission. The facilities of these gas utility companies were found to constitute an integrated gas utility system. ${ }^{197}$

\section{Community Gas E' Power Company}

American Gas \& Power Company, a subsidiary of Community Gas \& Power Company, was the parent of seven operating gas utility subsidiaries doing business in the states of Minnesota, Alabama, Georgia, Florida, Massachusetts, and Maine. ${ }^{198}$ The largest of these was Minneapolis Gas Light Company which served an area with a population of

${ }^{197}$ Philadelphia Company, Release No. 8242 (June I, 1948).

${ }^{198}$ Each of the gas utility subsidiaries of Community Gas \& Power Company was subject to the direction and control of the parent company in New York City, a highly objectionable feature from the point of view of the Commission. 
543,000 and had, as of September 30, 1942, a gross plant account of $\$ 28,347,357$, net plant of $\$ 14,644,422$, gross annual revenues amounting to $\$ 6,975,830$, and net annual income of $\$ 1,039,099$. The other six companies were much smaller and combined did not equal Minneapolis in financial size. The Commission held that each of the seven operating companies constituted a separate integrated gas utility system. ${ }^{199}$ However, no two of them derived natural gas from a common source of supply or were operated together as a single coordinated system. The gas utility properties operated by Minneapolis Gas Light Company constituted the major utility system controlled by American Gas. It sold almost half of the gas sold by the entire system and produced approximately $60 \%$ of the system's revenues. American Gas agreed that Minneapolis Gas constituted its principal integrated system and consented to dispose of the other properties.

\section{Columbia Gas E Electric Corporation}

The major operations of the Columbia Gas \& Electric Corporation system were carried on by 5 subsidiaries which owned or operated facilities for the production, transmission, and distribution of natural, artificial, and mixed gas for heat and power. These subsidiaries rendered gas service in more than $\mathbf{1}, 200$ communities located in Kentucky, Maryland, Ohio, New Jersey, New York, Pennsylvania, Virginia, and West Virginia. ${ }^{200}$ Retail gas service was provided in each of these states except New Jersey. Ninety per cent of the operations of these subsidiaries was carried on in a relatively compact area in the adjoining states of Ohio, Pennsylvania, and West Virginia, the remaining operations being conducted in adjacent areas of Kentucky, western Maryland, and eastern

${ }^{190}$ Community Gas \& Power Company, I 3 S.E.C. 532 (1943).

${ }^{200}$ Columbia Gas \& Electric Corporation, I 7 S.E.C. 494 (1 944 ). 
Pennsylvania. In the major area 842,000 customers were served out of a total population of more than $3,600,000$. The distribution properties of the gas utility companies were for the most part interconnected by a network of lines which were connected with the producing properties of certain of the companies. From a management standpoint, the gas utility companies were segregated into three groups, namely, the Charleston, West Virginia, group; the Pittsburgh, Pennsylvania, group; and the Columbus, Ohio, group. Each group had its principal executive office in the city by which it was designated, and each had its own complement of executive and operating personnel. In general, the companies in each group were jointly operated as a group unit without regard for corporate boundaries. The executive, managerial, and operating personnel consisted, for the most part, of men residing in the communities served. A local office with a local manager was maintained in all communities of substantial size in the operating territories of the group. Each of the three groups maintained central dispatcher offices on a 24-hour basis for the purpose of assuring adequate deliveries of gas to the distribution outlets of the several companies. In addition, the facilities of the groups were so designed as to effectuate a substantial degree of operating coordination between their production and transmission facilities and the distribution systems of the various companies. The management of each group was responsible for the problems of local operation and policy, but they obtained certain statistical, accounting, tax, and other technical services from Columbia Engineering Corporation, the system service company. Further, the overall problems of policy, financing, protection of future gas supplies, and major engineering, legal, and tax questions were subject to the direct supervision of Columbia Gas \& Electric Corporation. The gas utility companies were subject to the jurisdiction of the regulatory commissions in the 
states in which they operated, and most of them were subject to the jurisdiction of the Federal Power Commission under the Natural Gas Act.

The distribution facilities of the Charleston group were with one minor exception connected with, and received their gas from, an interconnected transmission system owned and operated by companies in the group. Retail gas service was rendered in northwestern and central West Virginia, western Kentucky, and to a minor extent in southern Ohio. The population of this area was approximately 600,000 .

The companies in the Pittsburgh group distributed gas in eastern, western, and southern Pennsylvania, in adjacent portions of northern West Virginia and eastern Ohio, and in western Maryland. Customers totaled approximately 318,000. The distribution facilities of each of the companies in the group were directly or indirectly connected through a network of transmission lines owned and operated by companies in the group.

The Columbus group rendered gas service to over 400,000 customers in central, northern, and eastern Ohio, an area with a population of $1,275,000$. All of its distribution facilities were directly or indirectly connected through a network of transmission lines. These lines were also connected with the lines of the Charleston and Pittsburgh groups, as indicated above.

There was a substantial degree of operating coordination between the production and transmission facilities of the Charleston group and the production, transmission, and distribution operations of the Columbus and Pittsburgh groups, and also with respect to the exploration and drilling for gas, conservation of gas supplies, purchase of equipment, as well as an interchange of ideas in respect of common operating problems.

From the foregoing description of the gas utility subsidiar- 


\section{2 \\ PUBLIC UTILITY HOLDING COMPANIES}

ies of Columbia Gas \& Electric Corporation represented by the Charleston, Pittsburgh, and Columbus groups it would appear fairly obvious that these three groups together constituted a single integrated gas utility system under the statutory definition. The Commission, however, did not so hold. Instead, it concluded that the distribution properties of the three groups were retainable together under the standards of Section I I (b) (I) (A), (B), and (C) of the Act pertaining to the retention of a principal system and one or more additional systems. ${ }^{201}$ Although the result was the same, the Commission had made a careful study of the operations of the Columbia Gas \& Electric Corporation system and was in a position to pass upon the more difficult question of whether all three groups constituted one integrated system. It is unfortunate that the decision was not made. It must be said, at this point, however, that the Commission does not make a practice of side-stepping major issues.

Prior to this decision it had been determined that Panhandle Eastern Pipe Line Company could not be retained in the Columbia Gas \& Electric Corporation system. ${ }^{202}$ Panhandle Eastern was engaged in the business of producing, transmitting, and selling natural gas which it obtained from the Amarillo and Hugoton gas fields. Its pipe lines extended through Texas, Oklahoma, Kansas, Missouri, and Illinois to a point on the Indiana-Illinois border where a connection was made with a subsidiary, which in turn delivered the gas to a non-affiliated distribution system in Detroit. Another subsidiary sold gas obtained from Panhandle Eastern to customers at retail in Michigan and Indiana to approximately I,800 customers. There were no connections between the lines of Panhandle Eastern and its subsidiaries with those

${ }^{201}$ Columbia Gas \& Electric Corporation, I 7 S.E.C. 494 (1944).

${ }^{202}$ Columbia Gas \& Electric Corporation, i I S.E.C. 80 (1942). 
of any other company in the Columbia Gas \& Electric Corporation system, except for a connection with the Columbus group in Ohio. The connection was separated by a valve which was normally kept closed and the interchange of gas was negligible. There were no billings for such interchange. Panhandle Eastern and its subsidiaries bought no gas from, sold no gas to, and had no operating interrelationship with any other company in the Columbia Gas \& Electric Corporation system. The entire capacity of Panhandle Eastern was required for its own customers. ${ }^{203}$ Columbia Gas \& Electric Corporation agreed with the Commission that Panhandle Eastern had to be divested from the system under the requirements of the Act.

\section{Pennsylvania Gas EF Electric Corporation}

The Pennsylvania Gas \& Electric Corporation ("Penn Corporation") was the parent of nine gas utility subsidiaries operating in the states of New York, Pennsylvania, Rhode Island, and Massachusetts. The Commission had tentatively held that there were four separate public utility systems in the Pennsylvania Gas \& Electric Corporation holding company system, namely, (a) the natural gas operations carried on in the northern Pennsylvania-southern New York area, (b) the mixed and natural gas operations in southern Pennsylvania, (c) the manufactured gas operations in Rhode Island, and (d) the manufactured gas operations in Massachusetts. ${ }^{204}$ It was shown that Penn Corporation had no intention of interconnecting any of the four systems, and that the operations in northern Pennsylvania-southern New York constituted the principal system of the company. Of this

${ }^{200}$ Such capacity was in fact insufficient for its own customers, as will be shown in the American Light \& Traction Company case, discussed infra.

${ }^{204}$ Pennsylvania Gas \& Electric Corporation, Release No. 8025 (March 9, I 948 ). 
latter group, the two largest properties were North Penn Gas Company and Allegany Gas Company. North Penn served 10,800 natural gas customers in northern Pennsylvania, and Allegany served 2,180 customers in the same area and also in southern New York. The facilities of the two companies were interconnected at numerous points, and intercompany sales of gas were substantial. Both companies jointly owned and operated underground gas storage facilities in northern Pennsylvania and both obtained large portions of their gas requirements from a common source of supply. Allegany supplied all the natural gas requirements of two other subsidiaries of Penn Corporation, Crystal City Gas Company and Addison Gas \& Power Company. Crystal served approximately 5,903 customers in southern New York and Addison served about 570 customers in a neighboring community. Crystal City and Addison shared a common business office and the personnel of the two companies was virtually identical. The other two subsidiaries in this region were Alum Rock Gas Company and Dempseytown Gas Company. The facilities of these two companies were interconnected and were located about 30 miles south of the distribution system of the North Penn and Allegany properties. Alum Rock served about 425 customers and Dempseytown served about 360 customers. Dempseytown obtained a portion of its natural gas requirements from the same source as North Penn and Allegany. The offices of North Penn, Allegany, Dempseytown, and Alum Rock were located in the same building at Port Allegany, Pennsylvania, and the duties of virtually every member of the staff employed at such offices involved more than one of those companies. All maintenance work of these companies was directed from the office at Port Allegany and a central staff of employees from the office there actually engaged in the major repair work in connection with all the 
New York-Pennsylvania properties. The Commission held that those properties were an integrated gas utility system within the meaning of the Act. ${ }^{205}$ None of the other groups of properties were located close to or were interconnected with the New York-Pennsylvania facilities and there was no operational relationship between them. The Commission did not pass upon the question whether each of them was integrated, since they were not retainable in any event.

\section{Southern Union Gas Company}

Southern Union Gas Company operated a small but scattered group of gas utility and other properties in Arkansas, New Mexico, and Texas. The Arkansas subsidiary served 6,000 gas customers in the northwestern part of the state. New Mexico Gas Company operated natural gas transmission and distribution facilities in northwest New Mexico, serving 3,500 customers at retail in and around Santa $\mathrm{Fe}$, and 10,000 customers in Albuquerque at wholesale. New Mexico Eastern Gas Company operated natural gas transmission facilities and distribution properties in east central and southeastern (Clovis and Carlsbad) New Mexico and in west Texas. The company served 9,900 retail customers and 2,900 wholesale. Texas Southwestern Gas Company operated natural gas transmission and distribution properties in four geographically separate districts in southwest Texas, southeast Texas, central Texas, and central Oklahoma, serving 8,700 customers. With minor exceptions, Southern Union and its subsidiaries had constructed all of the physical properties and utility plants of the system, locating them in scattered communities in which natural gas had not previously been made available.

Under Section I I (e) of the Act, Southern Union proposed,

\footnotetext{
${ }^{205}$ Pennsylvania Gas \& Electric Corporation, Release No. 8490 (September $3,1948)$.
} 
inter alia, to merge itself with New Mexico Gas Company, and New Mexico Eastern Gas Company with Texas Southwestern Gas Company. Southern Union proposed to retain the gas utility properties of New Mexico Gas Company, New Mexico Eastern Gas Company, located in New Mexico, and the southwest Texas properties of Texas Southwestern Gas Company, located in the Pecos Valley, as its principal system. The Commission held that such properties did constitute a single integrated gas utility system within the meaning of Section 2(a) (29) (B) of the Act. ${ }^{206}$ The Commission justified this decision as follows:

“... This conclusion is reached on the particular facts here applicable although we recognize that the properties extend over a rather wide geographical area. The record shows, among other things, that the territory served has a relatively sparse population and that the properties are of such size and are so situated as to permit efficient operation under a single management responsive to local public feeling and local needs."207

In view of the wide extent of these properties (more than 300 miles north to south and more than 200 miles east to west), the lack of a common source of supply, and the consequent absence of coordinated operations, the decision is hard to defend on any ground other than that the properties involved were small. The Act itself, of course, makes no special provision for small operations. The Commission also fell back on its "sparse population" doctrine which has already been examined at length in the discussion of The Middle West Corporation.

208 Southern Union Gas Company, I 2 S.E.C. I I6 (1942). The southeast Texas, central Texas, and central Oklahoma properties of Texas Southwestern Gas Company, located 350,250 , and 300 miles respectively from the nearest point of the principal system, were held in this opinion not to be a part of the principal system.

${ }_{207}$ Southern Union Gas Company, 12 S.E.C. I I6, I42 (1942). 


\section{Cities Service Company}

There were three important groups of gas utility properties in the Cities Service Company system. The largest group (considering gross operating revenues) was located in the states of Oklahoma, Missouri, Kansas, and Nebraska, and will be referred to herein as the "Mid-Continent" gas properties. The next largest system was that operated by Arkansas Louisiana Gas Company in Texas, Louisiana, and Arkansas. And the third group, which was much smaller, consisted of properties in New York and Canada, and will be referred to as the "Northern" group.

\section{The Mid-Continent Properties}

The Mid-Continent gas properties consisted of the distributing systems of Kansas City Gas Company, The Wyandotte County Gas Company, and The Gas Service Company. The service area of these companies comprised about 50,000 square miles, principally in eastern Kansas. Gas service was rendered in Kansas City, Missouri; Kansas City, Kansas; the environs of these two cities; and 159 communities in eastern Kansas, southwestern Missouri, northeastern Oklahoma, and southeastern Nebraska. Of a total population of I 204,600 , there were 272,000 customers. The gas distributed by these companies was purchased from a common source of supply, Cities Service Gas Company, a system company. The various retail outlets of the three companies were connected by the lines of Cities Service Gas Company, and all three were coordinated as to load increase or decrease by a department of that company. The three companies had substantially the same management. The central offices of Gas Service and Kansas City Gas were located in the same building in Kansas City, Missouri, while the central offices of Wyandotte were in Kansas City, Kansas, three miles away. 
In purchases, construction, advertising, and exchange of ideas, the companies were operated as a single enterprise. The Commission accordingly found that these three companies formed an integrated gas utility system. ${ }^{208}$

\section{Arkansas Louisiana Gas Company System}

Arkansas Louisiana Gas Company, hereinafter referred to as "Arkansas Gas," produced and transmitted natural gas and distributed it at retail and wholesale in Arkansas, Louisiana, and Texas. The area served formed a triangle, encompassing approximately $3 \mathrm{I}, 000$ square miles, with the base of the triangle in northern Louisiana and its apex in lower Arkansas. Lines ran west into east Texas and north into upper Arkansas. Within this area, which had a population of over I,500,000, the company had IO3 distribution plants, all coordinated with the production and transmission properties so that at all times the requirements of each outlet were anticipated and could be satisfied. The distributing system was divided into 33 field offices, each possessing local control, but all subject to general coordinating authority from the company's main offices located at Shreveport, Louisiana. It was held that Arkansas Gas operated a single integrated gas utility system. ${ }^{209}$

\section{The Northern Properties}

The companies in the Northern group of gas properties were Republic Light, Heat \& Power Company, Inc., PennYork Gas Company, and Dominion Natural Gas Company, Ltd. (and its subsidiaries). These companies operated in Pennsylvania, New York, and Canada. Republic distributed both natural and manufactured gas in western New York, serving natural gas to 49 small communities in three areas with a population of 132,000 , and manufactured gas to nine

${ }^{208}$ Cities Service Company, 15 S.E.C. 962,967 (1944).

${ }^{2008} I d$. at 996. 
communities in the Niagara Falls area with a population of 169,000. The two divisions of the company were so coordinated that if the supply of natural gas should fail, Republic could mix manufactured gas with natural gas. Republic was found to constitute a single integrated gas utility system. ${ }^{210}$ The Commission did not pass upon the status of Penn-York Gas Company and Dominion Natural Gas Company under Section 2(a)(29)(B).

\section{Lone Star Gas Corporation}

Through its operating subsidiaries, the Lone Star Gas Corporation produced, purchased, transmitted, and distributed natural gas in Texas and southern Oklahoma, and also distributed natural gas in the city of Council Bluffs, Iowa. ${ }^{211}$ Council Bluffs Gas Company purchased its gas requirements from Northern Natural Gas Company. Northern Natural had been organized in 1930 by North American Light \& Power Company, United Light \& Railways Company, and Lone Star Gas Corporation, each of which held approximately one-third of the Northern Natural common stock. United Light \& Railways disposed of its interest in Northern Natural by sale to underwriters for public distribution. ${ }^{212}$ The Commission in 1942 ordered North American Light \& Power Company to sever its relationship with Northern Natural. ${ }^{213}$ Northern Natural was both a registered holding company and a non-utility operating company. It produced and purchased natural gas in Texas and Kansas, and operated a pipeline for transporting such gas from those states to Nebraska, South Dakota, Iowa, and Minnesota,

${ }^{210} I d$. at 990 .

${ }^{211}$ The properties of Lone Star Gas Corporation were concentrated in north central Texas and south central Oklahoma.

${ }_{212}$ The United Light \& Power Company, Io S.E.C. I7 (194I).

${ }^{218}$ The North American Company, II S.E.C. I94 (1942). But see The North American Company, 13 S.E.C. 98 (1943), and 18 S.E.C. 459 (1945). 
where it sold the gas for industrial use and at wholesale for redistribution. Through its wholly-owned subsidiaries, Peoples Natural Gas Company and Argus Natural Gas Company, it distributed natural gas in Kansas, Nebraska, Iowa, and Minnesota.

Pursuant to Section I I (e) of the Act, Lone Star Gas Corporation proposed to retain the subsidiaries operating in Texas, to sell Council Bluffs Gas, and to distribute the common stock of Northern Natural owned by it to its stockholders. Lone Star contended that all of its distribution properties in Texas and Oklahoma were retainable as a single integrated system. Excluding the distribution systems at El Paso and Galveston, Texas, the utility properties which would remain after the disposition of Northern Natural and Council Bluffs Gas were all situated and compactly grouped in northern and north central Texas, and a small adjoining portion of southern Oklahoma. These properties will be referred to herein as the "Central System." No single distribution system was located more than 47 miles from another Lone Star distribution system, and the average distance between the cities and towns served by the Central System was less than ten miles. As may also be noted, this area was located primarily in a single state, Texas. The utility operations of the Central System consisted of the distribution of natural gas in and around $29 \mathrm{I}$ cities and towns and the retail sales of gas to individual customers along the pipe lines of Lone Star Gas Corporation. All of the distribution properties of the Central System were connected with, and received their gas from, the interconnected transmission system of Lone Star Gas Corporation, with one minor exception. All operations of the Lone Star System in Texas and Oklahoma were managed from the system's main office in Dallas, centrally located in the Central System area, thus facilitating localized management of the properties. 
Although the Central System was large, in general it had common physiographical and economic characteristics. Furthermore, the area served was sparsely populated, having a population of only I,300,000. The Central System served an average of 285,787 customers in 194I. Most of the communities served were small, and it was unlikely that they could support independent gas distribution systems.

There was a considerable degree of operating coordination between the companies owning distribution properties in the Central System. This portion of the Lone Star system was divided into seven operating divisions, and four of these divisions were subdivided into operating districts. These operational partitions were arranged without reference to the corporate ownership of the individual properties. Within each district and division, operations were coordinated by the respective district and division offices, and as between the divisions there was additional coordination of operations.

The operations of the system in Texas were subject to regulation by the Railroad Commission of Texas and were subject to rate regulation by the cities served. Operations in Oklahoma were subject to regulation by the Corporation Commission of that State.

The Commission found that the distribution operations of the Central System could be retained as the single integrated public utility system of Lone Star under Sections I I (b) (I) and 2 (a) (29) (B) of the Act. ${ }^{214}$

Neither the Galveston nor the El Paso properties were connected with the pipelines of Lone Star Gas Corporation. Natural gas for distribution in those cities was purchased at wholesale from companies not affiliated with the Lone Star system. Both El Paso and Galveston were located a considerable distance from the Central System. Galveston was 250 miles from Dallas and 125 miles from College Station,

${ }^{24}$ Lone Star Gas Corporation, I2 S.E.C. 286 (1942). 
the nearest town served by the Central System. El Paso, which was 700 miles from Galveston, was 575 miles from Dallas and 350 miles from the town of Colorado, the nearest served by the Central System. Several other companies not affiliated with the Lone Star system distributed gas in the territories around El Paso and Galveston, and in the areas between those two cities, and between those cities and the Central System. There appeared to be very little operating coordination, as distinguished from management or control coordination, between the properties in $\mathrm{El}$ Paso and Galveston and those in the Central System. Although the distribution systems at El Paso and Galveston were operated subject to the authority of the management of the system's main office in Dallas, each was operated as a separate division, each having a complete and self-sufficient staff of qualified operating personnel. In view of this, and since it appeared that the EI Paso and Galveston properties were not in the same "area or region" as the properties of the Central System, within the meaning of Section 2(a) (29)(B), the Commission held them not to be a part of the retainable single integrated public utility system. ${ }^{215}$

Accordingly, the Section I I (e) plan of Lone Star was approved, except that the retention of the El Paso and Galveston properties was not permitted. ${ }^{216}$

\section{The United Light $\mathcal{E}^{2}$ Railways Company}

The United Light \& Railways Company and its subsidiary, American Light \& Traction Company, filed a joint plan under Section I I (e) of the Act for compliance with Section Ir (b) thereof. As to its integration features, the plan provided for the continuation of American as a holding company over

${ }^{215}$ Ibid.

${ }^{210}$ See Lone Star Gas Corporation, I5 S.E.C. I66 (1942), for a review of the steps taken by this system to integrate itself. 
Michigan Consolidated Gas Company, Milwaukee Gas Light Company, and Michigan-Wisconsin Pipe Line Company, and their subsidiaries, and for the disposition by American of its investments in The Detroit Edison Company and Madison Gas and Electric Company. The United Light \& Railways Company, which became a top holding company upon the dissolution of The United Light \& Power Company, ${ }^{217}$ owned $51.94 \%$ of the voting stock of American Light \& Traction Company. The plan proposed to divorce American from United, and we are here concerned with the integration of the American system.

American Light \& Traction owned all of the common stocks of Michigan Consolidated, Madison, and Michigan-Wisconsin; approximately $99.5 \%$ of the common stock of Milwaukee; and approximately $20.3 \%$ of the common stock of The Detroit Edison Company.

Michigan Consolidated Gas Company was engaged in the purchase, distribution, and sale of natural gas in Detroit, Grand Rapids, Muskegon, Ann Arbor, Mt. Pleasant, Greenville, Belding, and Big Rapids, Michigan, and adjacent areas. It was also engaged in the production, distribution, and sale of casing-head gas in Muskegon and of manufactured gas in Ludington, Michigan. At the time of the hearing, natural gas for sale in Detroit and Ann Arbor was secured by contract from the Panhandle Eastern Pipe Line Company. This supply was supplemented by manufactured gas. Michigan Consolidated also owned gas wells and had gas rights in west central Michigan, the output of which was used to service the other Michigan communities. Its business was conducted entirely within the state of Michigan. Its service area had an

${ }^{217}$ The United Light \& Power Company, 13 S.E.C. x (1943); plan approved and enforced, In re United Light \& Power Company, 5 I F. Supp. 2 I 7 (D.C. Del., 1943), affirmed sub nom. In re Securities \& Exchange Commission, 142 F.(2d) 4 I I (C.C.A., 3d. Cir., 1944), and Otis \& Company v. Securities \& Exchange Commission, 323 U.S. 624 (1945). 


\section{4 PUBLIC UTILITY HOLDING COMPANIES}

estimated aggregate population in 1940 of $2,345,600$, of which I,959,600 were in the Detroit district. Approximately $8 \mathrm{I} \%$ of its operating revenues for 1946 was derived from the sale of gas in the Detroit district. Michigan Consolidated was under the jurisdiction of the Michigan Public Service Commission, which had broad regulatory powers over the company, including jurisdiction over the fixing of rates and charges, and the issuance of securities.

Milwaukee Gas Light Company was a gas utility company, furnishing manufactured gas to the city of Milwaukee and the surrounding metropolitan area, having a combined population of about 800,000 . During 1946 approximately $31.77 \%$ of its gas requirements was supplied from the company's own manufacturing equipment, and the remainder was purchased from Milwaukee Solvay Coke Company, a wholly owned subsidiary of Milwaukee. Milwaukee was under the jurisdiction of the Public Service Commission of Wisconsin, which had extensive regulatory powers, including jurisdiction over the fixing of rates and charges, and the issuance of securities.

Milwaukee Solvay Coke Company was a non-utility company operating in the city of Milwaukee. It manufactured and sold coke and coke by-products, and furnished Milwaukee Gas Light with a substantial portion of its requirements of manufactured gas. It was expected that when natural gas should be introduced into Milwaukee, Milwaukee Solvay would continue in business but would reduce its supplies to Milwaukee Gas Light to a stand-by basis.

Madison Gas \& Electric Company was a combined electric and gas utility company engaged in the production, distribution, and sale of electricity and manufactured gas in Madison, Wisconsin, and adjacent territory.

Michigan-Wisconsin Pipe Line Company was organized 
in 1945 for the purpose of constructing and operating a natural gas pipe line from Texas to Michigan and Wisconsin. It was a non-utility company. At the close of the hearings in this case, construction of the pipe line had not commenced, but contracts for raw materials, construction, engineering and gas supply had been entered into.

Austin Field Pipe Line Company was a Michigan corporation organized for the purpose of constructing a pipe line extending from the Austin storage field in Michigan to Detroit, and connecting certain of Michigan Consolidated's distribution systems with the Austin field. When constructed, the line would be temporarily operated under lease by Michigan Consolidated and later acquired by Michigan-Wisconsin. It was a non-utility company.

The United Light \& Railways Company had previously been ordered to dispose of its interest in American Light \& Traction Company, and American had in turn been directed to dispose of its interest in all properties outside of Michigan or states which adjoin Michigan, and also to dispose of its investment in Detroit Edison. ${ }^{218}$ At the date of this hearing, Railways had not disposed of its interest in American, nor had American disposed of its investment in Detroit Edison. The question was still open whether the remaining properties of American constituted integrated systems and other businesses retainable under Section I I (b) ( I). One of the premises of the Section II (e) plan was that Michigan Consolidated and Milwaukee would form such an integrated system which could be retained by American. As part of this plan it was proposed to construct the interstate natural gas pipe line joining Michigan Consolidated and Milwaukee, described above. ${ }^{219}$ American was to continue in existence as a registered

${ }^{218}$ The United Light \& Power Company, 9 S.E.C. 833 (1941).

${ }^{219}$ As the main line passed through Missouri and Iowa, certain small communities were to be served with gas. 
holding company over Michigan Consolidated, Milwaukee, Milwaukee Solvay, Michigan-Wisconsin, and Austin. During the year 1948, American proposed to pay quarterly dividends on its common stock in shares of Detroit Edison stock. The resources and credit of American were to be used to provide the common stock equity for the proposed pipe line system. The pipe line was to be financed, primarily, from the sale of large blocks of Detroit Edison stock owned by American. All of American's Detroit Edison stock was to be disposed of prior to December 3 I, 1948. The common stock of Madison Gas \& Electric Company was to be distributed pro rata to the common stockholders of American. Railways was to dispose of all shares of preferred and common stocks of American held by it, and all shares of Detroit Edison and Madison received by it in distribution from American. The Commission was not called upon nor did it have the power to determine the merits of the pipe line as such, for that matter lay wholly within the jurisdiction of the Federal Power Commission and had already been decided in the affirmative. ${ }^{220}$

Natural gas was being obtained by Michigan Consolidated from Panhandle Eastern Pipe Line Company under a contract entered into in 1935. Panhandle produced and purchased gas in the states of Texas, Oklahoma, and Kansas, and owned and operated a transmission pipe line system extending from those states through portions of Missouri, Illinois, Indiana, Ohio, and Michigan. By separate contract, Panhandle delivered gas to Michigan Consolidated for distribution in the Ann Arbor area. Ann Arbor also received natural gas produced in Michigan. The communities in western Michigan served by Michigan Consolidated, with the exception of Ludington, which used manufactured gas, obtained their supply from natural gas fields in Michigan. An additional

${ }^{200}$ The United Light \& Railways Company, Release No. 795 I (December 30, I 947), mimeo. p. 14. 
supply of natural gas was essential to continuance of service in those communities. There had also been a rapidly expanding demand for gas in the heavily industrialized area around Detroit served by Michigan Consolidated. Restrictions on the construction of new facilities during World War II, the limited availability of materials since the termination of hostilities, and the heavy gas demands in other regions served by Panhandle had made it impossible for Panhandle to keep pace with the growth of the Detroit market. As a result, that area was suffering from an acute shortage of natural gas, and Michigan Consolidated had been compelled during peak periods to supplement its receipts from Panhandle with manufactured gas at greatly increased expense. It had also been necessary to discontinue gas service to certain industrial customers in Detroit during brief periods of extraordinary demand, to suspend acceptance of additional space heating customers, and to restrict the amount of additional gas sold to industrial customers. The send-out of Michigan Consolidated in the Detroit area exceeded the 125,000 Mcf. provided by the Panhandle contract on five days in 1942, 14 days in 1943 , 1 3 days in 1944, 32 days in 1945, 97 days in 1946, and 108 days in the first four months of 1947 , demonstrating vividly the growing shortage. On occasions Panhandle had been unable to deliver the quantities of gas called for in the contract.

Michigan Consolidated had plants in Detroit, Grand Rapids, Ann Arbor, and Muskegon equipped to produce carburetted water gas, which resembled natural gas in quality and could be used as a temporary substitute for, or in simultaneous distribution with, natural gas. In Detroit the company had recently installed a new liquefied petroleum gas manufacturing plant. These facilities were insufficient to supply the full gas demands of the system and were used only for stand-by purposes to level peak demands or in case of temporary curtailment or failure of the natural gas supply. 
The gas supply situation of the Wisconsin companies was somewhat different but also indicated an urgent need for new sources of supply. Both Milwaukee and Madison used only manufactured gas. The record indicated that Milwaukee had been unable to earn its allowable return and that, as a consequence of the rapidly increasing expense of manufacturing gas, it had been compelled twice in the previous year to apply to the state commission for an increase in rates, which were granted to the extent of $\$ 1,575,000$ per year. In addition, the demand in Milwaukee had increased to a point where either additional manufacturing facilities had to be installed to maintain service or some other source of supply had to be provided.

As has been indicated, on November 30, 1946, the Federal Power Commission granted a Certificate of Convenience and Necessity to Michigan-Wisconsin to construct and operate a natural gas pipe line from the Hugoton gas fields to points in Michigan and $W$ isconsin. A second certificate was granted on November I 3, I 947, to Austin to operate the Austin field and to build a line from that field to Detroit and other points in Michigan. The main pipe line to be constructed by MichiganWisconsin was to be a 24-inch line from a point in Hansford County, Texas, extending for $8 \mathrm{ro}$ miles in a northeasterly direction to a point near Millbrook, Illinois, referred to as "Wisconsin Junction." From that point a 22-inch line was to extend 259 miles through Indiana and Michigan to the Austin Field, where the line would terminate. From Wisconsin Junction another 22-inch line would extend ror miles to a point near Milwaukee referred to as "Milwaukee Junction." An I 8-inch line was to extend from there to the Milwaukee area, and a 14 -inch line was to extend 59 miles to a point near Appleton. Branches from the I4-inch line were to extend to Sheboygan, Fond du Lac, Oshkosh, Manitowoc, Two Rivers, Appleton, and Green Bay. A 12-inch branch was to extend 
from Milwaukee Junction to Racine, and a Io-inch line to Madison, with further branches. The branch lines serving Wisconsin were to total 422 miles.

At the Austin and Reed City gas storage fields, Austin Field Pipe Line Company proposed to install additional wells and gathering lines, and was to construct a 24 -inch line approximately I 40 miles long connecting the Austin storage field with Michigan Consolidated's distribution system in the Detroit area. A branch line of approximately 25 miles was proposed to connect the Austin-Detroit line with Ann Arbor.

Construction of the Austin-Detroit line was to start immediately, with completion expected by April I, I 948. Initially, the line was to be used for transporting to and from the storage fields gas delivered from Panhandle to Michigan Consolidated, the contracting parties having agreed to such storage, which would enable Michigan Consolidated to build up reserves for the winters of I948-1949 and 1949-1950, before the Michigan-Wisconsin line went into operation. It was expected that natural gas from the main line would enter the Detroit area by January I, I950. The underground storage fields would permit the main line to be operated at full capacity all of the time, the amounts not immediately consumed during slack periods being directed into storage and available to meet peak demands. Practically the entire peak demands of Detroit, Ann Arbor, and Mt. Pleasant could be met from storage. The capacity of the storage fields was enough to meet peak requirements for an uninterrupted period of approximately 100 days. This storage system could double the designed capacity of the main transmission line. Michigan-Wisconsin had entered into a gas supply contract with Phillips Petroleum Company to supply the natural gas for the line.

In considering whether the operation of the properties of Michigan Consolidated and Milwaukee would be coordinated, and, if so, whether such coordination would result in substan- 
tial economies, the Commission pointed out that the utilization of underground storage would enable the proposed pipe line to operate at full capacity the year round and permit significant economies in operation and cost. ${ }^{221}$ The proposed method of operation would make for close coordination between the operations of Michigan Consolidated and Milwaukee, with central control synchronizing these operations to assure maximum use of the lines, adequate pressures in the lines and in the storage fields, and allocation of gas to new customers in terms of line capacity and mutual needs. The record indicated that substantial economies would result from the pipe line. An adequate supply of additional natural gas to Michigan Consolidated would save the large expenditures for manufactured gas then required during peak periods and would assure adequate supplies to the western districts of Michigan which were threatened with a severe shortage. Conversion to natural gas by Milwaukee would make additional expansion of manufacturing capacity by that company unnecessary and would bring in gas at a price which would enable it to earn a fair return, while the consumers in Wisconsin would be benefited by a reduction in gas rates. And the availability of additional gas would permit natural expansion of demand. The Commission found that this coordinated operation of Michigan Consolidated and Milwaukee would result in substantial economies. ${ }^{222}$

${ }^{2 x}$ The Federal Power Commission found that:

"The proposed project has a distinct and readily recognizable advantage over the ordinary interstate natural-gas transmission pipe line system. The advantage lies in the fact that the project combines the operations of a highpressure pipe line with the utilization and operation of large gas fields for underground storage purposes. This combination of transport and large scale storage facilities makes possible important economies in operation, permits flexibility and superior reliability of service, and enables a high load factor operation of the main pipe line system." F.P.C. Opinion No. 147 at mimeo. p. I I , quoted in The United Light \& Railways Co., Release No. 7951 (December 30, 1947), mimeo. p. 25.

${ }_{222}$ The United Light \& Railways Company, Release No. 7951 (December 30,1947 ). 
The next problem was whether the proposed system was located in a "single area or region." Section 2(a)(29)(B), of course, provides that companies deriving natural gas "from a common source of supply" may be deemed to be in a single area or region. The Michigan-Wisconsin pipe line would provide Michigan Consolidated and Milwaukee with a common source of supply. If Panhandle Eastern should agree to continue to serve Michigan Consolidated after the expiration of the contract described above, Michigan Consolidated would then obtain its gas from two sources, one of which would not be available to Milwaukee. The Commission met this problem as follows:

". . . However, the statute does not require the companies to obtain all their gas from a common source of supply and since Michigan Consolidated will obtain most $(67 \%)$ of its gas from Michigan-Wisconsin, we need not determine whether the quoted provision of Section 2(a)(29)(B) would be applicable if the situation were reversed. Under the circumstances presented, we think that Michigan Consolidated and Milwaukee would derive gas 'from a common source of supply' and that their operations might properly be regarded as confined to a 'single area or region.' "223

The final question was whether the size of the area or region served by this system was so large as to impair the advantages of localized management, efficient operation, or the effectiveness of regulation. Detroit, the principal market of Michigan Consolidated, was 249 airline miles and 368 railroad miles from Milwaukee. Their combined utility plant amounted to $\$ 133,488,24 \mathrm{I}$. Total operating revenues for the two companies for the twelve months ending April 30, 1947, were $\$ 45,550,679$. The population in 1940 of the region served by Michigan Consolidated was estimated at 2,345,600,

${ }^{223} I d$. at mimeo, pages $26-27$. 
of which 603,089 were customers of the company. The areas served by Milwaukee had a population of approximately 800,000 , of which 203,433 were customers. No objection had been made that the system would be so large as to impair efficiency of operations, although it is the largest gas utility that has yet been considered as integrated.

Michigan Consolidated would remain subject to regulation by the Michigan Public Service Commission and Milwaukee would remain subject to regulation by the Public Service Commission of Wisconsin. Michigan-Wisconsin would be under the jurisdiction of the Federal Power Commission, and American Light \& Traction would remain a registered holding company subject to the jurisdiction of the S.E.C. The Commission concluded that the area or region to be served by the proposed coordinated operations was not so large as to impair the effectiveness of regulation. ${ }^{24}$

The Commission pointed out that the management of Michigan Consolidated and Milwaukee had always resided in the communities served and had had continuous responsibility for operating and managing the properties, adding that:

". . . While it is true that instances may arise in the coordinated operation of the proposed system in which the immediate interests of a particular territory may not be fully satisfied, such an eventuality is characteristic of the very nature of coordination which is conducted with the overall and long run needs of all system properties in mind. Moreover, any such instances are more than offset by the advantages to be derived by the consumers of the territories from such proposed coordination, and they need not necessarily result in impairment of local management to an extent which would be in- 
consistent with the standards of Section 2 (a) (29)(B). ${ }^{3225}$

The conclusion naturally followed that the combination of the properties of Michigan Consolidated and Milwaukee constituted an integrated gas utility system within the meaning of the Act. ${ }^{228}$

This decision of the Commission was attacked by Panhandle Eastern Pipe Line Company upon appeal. Panhandle Eastern maintained that the evidence did not support the Commission's findings that Michigan Consolidated and Milwaukee could be retained by American as an integrated gas utility system, that the Commission was without power to anticipate the construction of the Michigan-Wisconsin or the Austin lines in determining whether an integrated system would exist, but should deal with the holding company system as it then existed, and that the economies found by the Commission would result from savings accomplished by the use of natural gas and not from the coordinated operation of the system as required by Section 2(a) (29)(B) of the Act. Each of these contentions was overruled and the decision of the Commission was affirmed. ${ }^{227}$

\section{The North American Company}

It will be recalled that the Commission found that the electric utility operations of Union Electric Company of Missouri constituted the principal integrated utility system of The North American Company. The gas operations in the Union group territory were conducted by Union Electric

$=$ Id. at mimeo. pages 27-28. It thus plainly appears that coordination over a wide area appealed more to the Commission than localized control, and the provisions of the Act calling for local management were relegated to a position of minor importance.

${ }^{m}$ The United Light \& Railways Company, Release No. 7951 (December 30, I 947 ).

${ }^{22}$ Panhandle Eastern Pipe Line Company v. Securities \& Exchange Commission, 170 F.(2d) 453 (C.A., 8th Cir., 1948). 
Company of Illinois in Alton, Illinois; by Iowa Union Electric Company in Keokuk, Iowa; and by St. Louis County Gas Company in an area surrounding the city of St. Louis. ${ }^{228}$ The first two companies were subsidiaries of Union Electric Company of Missouri, and the last was a direct subsidiary of North American. The gas operations of the three companies were located within the electric service territory of the Union group. Although the gas operations of the Iowa and Illinois companies were relatively small, the total assets of the St. Louis County Gas Company amounted at May 3 I, I 940, to the substantial sum of $\$ 9,944,909$. Without further analysis of the question, the Commission held that the gas operations of these three companies constituted those of three integrated gas utility systems. ${ }^{229}$

North American Light \& Power Company, a subsidiary of. The North American Company, owned 35\% of the common stock of Northern Natural Gas Company. ${ }^{230}$ Northern owned transmission lines and sold natural gas at wholesale for redistribution and for industrial use. Its transmission lines, which constituted the major portion of its assets, tapped fields in Texas and Kansas, and ran for a distance of 2,783 miles through Oklahoma, Kansas, Nebraska, South Dakota, Iowa, and Minnesota. Northern was not a "gas utility company" within the meaning of Section 2(a)(4) of the Act. ${ }^{231}$ However, Northern owned all of the common stock of Peoples Natural Gas Company and Argus Natural Gas Company which maintained facilities for the sale of natural gas at re-

22 The gas utility subsidiaries of The North American Company system were all concentrated in the mid-western states, with the exception of one subsidiary in California.

${ }^{229}$ The North American Company, 1 I S.E.C. 194 (1942).

${ }^{200}$ United Light \& Railways Company also owned $35 \%$ and Lone Star Gas Company owned $30 \%$ of the Northern Natural Gas Company common stock. The North American Company, I I S.E.C. I 94 ( I 942 ).

${ }^{231}$ Sec. 2 (a) (4) of the Act defines a "gas utility company" as "any company which owns or operates facilities used for the distribution at retail ... of natural or manufactured gas for heat, light, or power . . " (Italics added.) 
tail and were gas utility companies within the meaning of the Act.

Peoples sold natural gas at retail in 66 cities and towns in three separate areas located in eastern Nebraska, central Iowa, and southern Minnesota, which latter area overlapped into northern Iowa. In 1940 Peoples served a total of 19,513 customers with over 3,500,000 mcf. of gas. All of Peoples' gas supply was derived from its parent, Northern.

Argus' properties were located in southwestern Kansas. It sold natural gas in I 5 communities and seven counties in that part of the state, and in 1940 served 5,575 gas customers, to whom 2,337,860 mcf. of gas were sold. Argus owned about I 5 I miles of gas transmission lines, 73 miles of branch lines, and 24 miles of gathering lines. It purchased its gas requirements principally from non-associated producers in the Kansas Hugoton field and to a small extent from its parent, Northern.

Northern, Peoples, and Argus, in combination, served areas aggregating 25,000 square miles, containing a population of 850,000 persons. On a consolidated basis as of December $3 \mathrm{I}, \mathrm{I} 940$, the group had fixed assets with a book value of $\$ 55,384,707$ and total operating revenues for 1940 of $\$$ I $2,857,002$. During I 940 the group sold $55,873,808$ mcf. of gas.

North American contended that the operations of Northern, Peoples, and Argus constituted those of a single integrated gas utility system. The Commission pointed out a number of objections to this proposition. It was emphasized that Argus purchased almost all of its gas from non-affiliated sources, while Peoples acquired its gas from Northern, and that the operations of the Argus properties had a much less important relationship to those of Northern than did the operations of Peoples. Furthermore, there were important differences in their methods of operation. The Commission was unable to 


\section{26 PUBLIC UTILITY HOLDING COMPANIES}

find that there were substantial economies, or any economies, resulting to Argus from joint ownership and control of its properties together with Peoples, and in its original opinion on the subject held that Argus could not be regarded together with Peoples and Northern as part of a single integrated gas system. ${ }^{232}$

It was suggested that the transmission lines of Northern might be considered, together with the properties of Peoples, as a single integrated gas utility system. Northern, however, was not a gas utility company within the meaning of the Act, as has been noted, and the Commission doubted whether the facilities of companies which were not gas utility companies could be regarded as part of an integrated gas utility system as defined in Section 2(a)(29)(B), which refers exclusively to "gas utility companies." This exclusive reference possibly precludes any intention to comprehend within an integrated gas utility system companies which were not gas utilities under the Act. However, the Commission did not decide this question, since it found that, in any event, Northern could retain the transmission lines along with Peoples under the "other businesses" clauses of Section I I (b) (I). ${ }^{233}$ The inference was that Peoples constituted a single integrated gas utility system, although the Commission did not make a specific finding to this effect.

North American succeeded in getting the Commission to reopen the hearings with reference to Northern's retention of the transmission lines and facilities of Argus. Proof was adduced to the effect that Northern's supply of natural gas was becoming more and more dependent upon Argus. About half of the gas requirements of Northern were produced in the Texas Panhandle field, the remainder being produced in the Hugoton, Otis, and Orth fields in Kansas. In 1940,

${ }^{233}$ The North American Company, I I S.E.C. 194 (1942).

${ }^{243}$ Ibid. 
$38 \%$ of this remainder was taken from the Hugoton field. The Otis field was relatively small and was in a decadent stage. Northern obtained only a minor portion of its requirements from the Orth field by purchase from non-affiliated interests. The Panhandle field had begun to show some drop in rock pressure, but there was no indication that material diminution of flow was imminent. The Hugoton field was only partially developed, and in Northern's opinion constituted its sole reserve source.

Northern owned leaseholds on 182,000 acres in the Hugoton field, 8,3 IO acres of which were producing through I 3 wells, I 2 of which were connected to Argus lines. Of this total acreage, I I 4,300 acres or $63 \%$ was traversed by, or adjacent to, the Argus pipelines. With the diminution of flow from the Otis field, Northern expected to accelerate development in the Hugoton field to compensate for this loss of supply and to meet increasing demands. Northern's demands had been constantly increasing and among its industrial consumers were several concerns engaged in substantial and important war production work. Northern contended that if such development was carried out in the acreage adjacent to the Argus lines, the use of such lines would constitute the logical and least expensive method of delivering the output to the Northern system, and that regulatory and defense agencies had indicated that no new facilities would be authorized where facilities were already available. It further appeared that Northern, to a considerable extent at that time and to an increasingly greater extent in the future, did and would depend upon the transmission facilities of Argus for the transmission to Northern's directly owned pipe lines of substantial amounts of gas from Northern's gas leaseholds.

In the light of these circumstances, the Commission held that the pipe line transmission facilities of Argus could logically be considered an integral part of the pipe line assets 
directly owned by Northern and which had previously been found to be retainable in the system. ${ }^{234}$ These assets, of course, were retainable for the same reason that the Northern transmission facilities were retainable, i.e., as an "other business" reasonably incidental or economically necessary or appropriate to the operations of the integrated public utility system of Peoples. It is not the purpose of this section to discuss the "other business" aspects of the Act; however, this background is essential to an understanding of the ultimate complete reversal by the Commission of its original position.

Not content with this state of affairs, Northern, Peoples, and Argus sought permission to retain the Argus distribution properties within Northern's integrated system. At the same time, Northern proposed to merge Argus into Peoples. The basis of this application was a change in conditions, as described below.

The Commission found that Peoples and Argus were physically interconnected by the Northern pipe line system, and that as a result major transmission policies affecting supply and regulation thereof were jointly determined for both companies. Consequently, the companies were operated as a coordinated system.

With reference to the "single area or region" requirement of Section 2(a) (29)(B) of the Act, as applied to this system, the Commission made these remarks:

"In spite of the wide intervening territory lying between them we think that Argus and Peoples may be deemed to lie in a single area within the meaning of the Act. Our conclusion is reached with especial refererence to the problems of the natural gas industry. Concern was expressed before the Committees of Congress with regard to area limitations in the natural gas industry, because of the necessity of bringing the fuel

${ }^{24}$ The North American Company, 13 S.E.C. 98 (1943). 
from its natural location to areas in which it could be economically sold, even though they lay great distances away. ... Under all the circumstances we think the conclusion that Peoples and Argus operate in a single area or region (is) consistent with the purposes intended by the Act."235

Relative to the "size" standards of the Act, it was shown that the combined facilities of Peoples and Argus served approximately 28,000 customers in $8 \mathrm{I}$ communities with a population of about $\mathrm{r} 35,000$. The combined net plant accounts of the companies was about $\$ 2,750,000$. Compared with other systems which had been held to be in compliance with Section 2(a) (29) (B), the system of Peoples and Argus was quite small. ${ }^{236}$ The system was found not to be so large as to impair the efficiency of operations. Although the combined operation of the two companies would not facilitate local regulation, the Argus properties would remain subject to the Kansas State Commission, and the system would remain subject to all federal regulation then applicable to it. ${ }^{237}$

Significant new evidence was adduced to show that the combined operation of Peoples and Argus under Northern control resulted in substantial economies which would be un-

${ }^{233}$ The North American Company, 18 S.E.C. 459, 462-463 (1945).

${ }^{236}$ Cf., Cities Service Company, is S.E.C. 962 (1944).

${ }^{227}$ In the North American Company, I I S.E.C. I 94 (1942), the Commission noted that the combined control of Argus and Peoples did not leave Argus subject to localized management. In the decision under consideration the Commission made these observations on the subject:

"... However, like all other standards of Section 2(a) (29) (B) the standard of localized management must be read in connection with the other provisions of the section. The extent of coordination, the relatively small size of the companies and communities involved, the necessity of widespread operations all tend to diminish the significance of the spread of the area as it affects localized management. Although there is little change in the evidence as to divisional operations and local determination of policy in the Argus territory the weight of that evidence increases when it is viewed in the light of the other factors." The North American Company, I 8 S.E.C. $459,463-464(1945)$. 


\section{30}

PUBLIC UTILITY HOLDING COMPANIES

available upon separation. A large portion of the claimed increase in Argus' operating expenses which would result from divestment was attributable to administrative and general expense, such as the salaries of the president and general manager, vice-president and assistant general manager, secretarytreasurer-comptroller, and clerks; legal fees; general office rent; and insurance premiums. Northern's estimate of savings was $\$ 29,840$ per year, and the Public Utility Division staff's was $\$ 17$, IOO. The Commission was of the opinion that the proper amount lay somewhere between the two amounts.

Studies of operating costs on a per customer basis were introduced, and they tended to show that Argus was operated more economically than the average of the independent natural gas companies included in the studies. However, the Commission expressed its doubt as to the relevance of such studies to this case, pointing out that the unique problems of operation of individual companies made comparability a difficult matter at best, and that the relevant issue was always whether the particular company would do better if independent. $^{238}$

The conclusion was therefore to the effect that Peoples and Argus, whose natural gas system extended 700 miles between extremities, could be retained together in compliance with Section I I (b) ( I ) as a single integrated gas utility system. $^{239}$

Des Moines Electric Light Company and Iowa Power \& Light Company, also North American subsidiaries, served eight communities in central Iowa with natural and manufactured gas. In 1940 these companies served 39,900 gas

${ }^{228}$ "The very existence of Section 11 (b) (I) shows that Congress has already concluded that, unless special evidence as to the special company before us warrants it, disposition must be ordered. In a sense, the broad issue dealt with by the staff has already been resolved by Congress." The North American Company, i 8 S.E.C. 459,465 ( 1 945 ).

${ }^{239}$ The North American Company, 18 S.E.C. 459 (1945). 
customers. Of these customers, $93 \%$ resided in the city of Des Moines. Total operating gas revenues for the year 1940 were $\$ 1,697,158$. The gas operations of these two companies were found to be those of a single integrated gas utility system. ${ }^{240}$

\section{The Mission Oil Company}

The Mission Oil Company proposed to retain as its principal integrated gas utility system its subsidiaries Amarillo Gas Company, Clayton Gas Company, Dalhart Gas Company, Red River Gas Company, Amarillo Oil Company, and West Texas Gas Company. These companies produced, purchased, transported, and distributed natural gas in an area approximately 400 miles north and south by 125 miles east and west, located in the western portion of the Texas Panhandle and northeastern New Mexico. The first four companies named were gas utilities and they served 92,92 I meters in 53 communities with an estimated population of 300,000 as of December 3I, I950. The gross property accounts of all of these companies as of April 30, 195 r, totaled \$24,301, 1 74, and the operating revenues of these companies for the 12 months ended that date amounted to $\$ 8,677,620$.

Substantially all of Red River's gas production was delivered in the field to West Texas, and this accounted for almost $50 \%$ of the requirements of West Texas in 1950 . The natural gas purchased by Amarillo Oil was transported through its gas transmission lines from the field to Amarillo Gas, with a small part thereof being sold to industrial consumers in the area. Amarillo Gas depended entirely upon this source of supply except for an emergency connection with West Texas and Red River. The facilities of Amarillo Gas and West Texas were physically interconnected through the transmission lines of Amarillo Oil.

${ }^{240}$ The North American Company, II S.E.C. 194 (1942). 


\section{I32 PUBLIC UTILITY HOLDING COMPANIES}

The allocation and transmission of natural gas in the system was under the control of a dispatcher who directed the production, purchase, and transmission of gas by Amarillo Oil and Red River to the gas utility companies. There were frequent exchanges of meters, regulators, and other supplies and materials between Amarillo Gas, Clayton, and Dalhart. Operating economies were achieved in the system's operations by virtue of centralized machine billing and bookkeeping and other administrative services conducted by Amarillo Gas. The executive officers and operating management of these subsidiaries were generally located in the service areas of the respective companies. The Commission concluded that the gas utility operations of Mission Oil constituted an integrated system retainable under Section I I (b) ( I $).{ }^{241}$

\section{General Public Utilities Corporation}

In another recent case it appeared that Jersey Central Power \& Light Company, a subsidiary of General Public Utilities Corporation, supplied manufactured, mixed, and natural gas in three separate areas of New Jersey. The population of the combined service areas was 295,000 and the average number of gas customers for the year I 950 was about 72,000 . The cost basis of these gas properties was $\$ 18,275,000$ at December 3 I, I950, with a net book value of $\$$ 1 3,322,000. Gas operating revenues for 1950 were $\$ 5,456,000$, and operating income before federal income tax was $\$ 474,000$. None of the three service areas was interconnected with either of the other two. Jersey Central had entered into contracts with Algonquin Gas Transmission Company with respect to its northern division, with Texas Eastern Transmission Corporation with respect to its Coast division, and with South Jersey Gas Company (itself a purchaser from Transconti-

${ }^{211}$ The Mission Oil Company, Release No. I0969 (December 2I, I95 I). 
nental Gas Pipe Line Corporation) with respect to its southern division for the daily purchase of natural gas. Upon completion of the necessary pipe lines, the company would then serve straight natural gas in all its systems. The conversions were expected by 1952 .

The Commission observed that the definition of a gas utility company in Section $2(\mathrm{a})(29)$ (B) of the Act did not require that the gas properties of the three divisions be interconnected or that they be capable of economic interconnection. Although each division would obtain its natural gas from a different source of supply when the pipe line connections were made, they were all located in the same state and were not widely separated from each other and it appeared that their joint operation would result in substantial economies. Accordingly, the gas properties of Jersey Central were held to be an integrated utility system. ${ }^{242}$

\section{Summary of Gas Utility Integration}

On the whole the question of gas utility integration has not been as troublesome as electric utility integration. This is true because of the localized nature and small extent of most gas systems, especially those distributing artificial gas. It is cheaper to manufacture artificial gas at each population center than to pipe it for long distances. The advent of natural gas systems has changed this situation considerably, however. Natural gas, which is found in only relatively few places in the country, can be transported long distances from those places in an economical manner. The natural gas industry was careful to see that such operations were not stifled by a definition of gas utility integration based upon a concept of manufactured gas operations. The results of the foresight of this group are clearly demonstrated in the American Light

${ }^{242}$ General Public Utilities Corporation, Release No. rog82 (December 28, 1951). 


\section{34 PUBLIC UTILITY HOLDING COMPANIES}

\& Traction Company and The North American Company cases. The "sparse population" theory with reference to size, which has been discussed at length under integration of electric utilities, was also applied to gas utility integration in the Southern Union and Lone Star Gas Corporation cases. Gas properties extending 300 miles north and south and 200 miles east and west were held to be integrated. This theory may well prove of benefit in the expansion of gas systems in the western sections of the country. It is important to note that in the American Light \& Traction Company case it was held that the phrase in Section 2(a)(29)(B), "deriving natural gas from a common source of supply," did not require that all of the gas of each company involved be derived from the same source, and held that a company deriving $67 \%$ of its supply from a common source met the test.

The Commission has not shown an inclination to adopt a strict interpretation of the Act with reference to localized management, efficient operation, and effective regulation. Although these requirements have not been wholly disregarded they have not played an important part in the gas utility integration decisions. 


\section{Chapter 3}

\section{The Retention of Additional Systems}

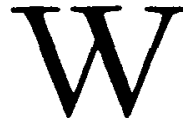

ITH reference to the retention of additional systems, Section I (b) (I) of the Act provides "That the Commission shall permit a registered holding company to continue to control one or more additional integrated public-utility systems, if, after notice and opportunity for hearing, it finds that-(A) Each of such additional systems cannot be operated as an independent system without the loss of substantial economies which can be secured by the retention of control by such holding company of such system; (B) All of such additional systems are located in one State, or in adjoining States, or in a contiguous foreign country; and (C) The continued combination of such systems under the control of such holding company is not so large (considering the state of the art and the area or region affected) as to impair the advantages of localized management, efficient operation, or the effectiveness of regulation." These three requirements set forth in the so-called " $\mathrm{ABC}$ " clauses were the result of the compromise between the House and the Senate concerning the retainability of utility systems by holding companies in addition to the principal group of properties. The Senate bill as originally passed did not permit any additional systems, while the House bill left the entire matter of integration largely to the discretion of the Commission.

The Commission has observed that, generally speaking, the $\mathrm{ABC}$ clauses envisage additional systems junior in importance to the principal system and usually dependent upon the continuance of joint control with the single system. ${ }^{243}$

${ }^{243}$ Cities Service Company, is S.E.C. 962 (1944). But see Columbia Gas \& Electric Corporation, I7 S.E.C. 494 (1944). 
Furthermore, the requirements of the $\mathrm{ABC}$ clauses are cumulative and all must be fulfilled before the retention of an additional system may be approved. ${ }^{244}$ Elimination of most of the possible additional systems has resulted from the application of these provisions of the Act, as will be shown more fully in the following discussion of each clause separately. ${ }^{245}$

\section{A. Loss of Substantial Economies}

The first of the cumulative requirements pertaining to the retainability of additional utility systems is that the Commission must find that each of such additional systems cannot be operated by an independent system without the loss of substantial economies which can be secured by the retention of control by the holding company of such system. ${ }^{246}$ The meaning of "substantial economies" is, of course, open to innumerable interpretations. The interpretation adopted by the Commission is shown by the ensuing case studies.

\section{Republic Electric Power Corporation}

The earliest decision involving Clause $\mathrm{A}$ arose under a plan filed by Republic Electric Power Corporation pursuant to Section II (e). This company was the parent of electric and gas utilities in southern Oregon, northern and southern California, and Oklahoma. The plan proposed the disposition of only the Oklahoma properties. The plan was approved by the Commission, which pointed out that the Oregon and California operations were isolated properties, small in size, and could not be separately operated without the loss of substan-

24t The North American Company v. Securities \& Exchange Commission, I 33 F.(2d) 148 (C.C.A., 2d Cir., 1943). Also see Engineers Public Service Company, iz S.E.C. 268 (1942).

${ }_{203}$ The application of these requirements has not substantially differed as between electric utility systems and gas utility systems, and therefore no distinction will be drawn between the two types of systems.

${ }^{246}$ Section I I (b) (I) (A), often referred to as "Clause A." 
tial economies. ${ }^{247}$ It was also noted that the plan called for the ultimate elimination of the holding company. This was obviously an expedient decision, hastily made in the same manner as the American Water Works \& Electric Company case discussed in Chapter II. ${ }^{248}$

\section{The North American Company}

The North American Company case was the first occasion upon which the Commission laid down definitive rules pertaining to the interpretation of Clause $\mathrm{A} .{ }^{249}$ The first postulate was that the phrase "substantial economies" in Clause A refers to economies which may be secured by the systems themselves, rather than to economies which may be secured by the holding company. ${ }^{250}$

North American argued that the requirement of substantial economies merely meant something more than nominal or "de minimis" economies. This argument was rejected by the Commission, which established the second postulate, to the effect that the word "substantial," as used here, means "important." The position of the Commission was that such meaning naturally resulted when the purpose of Congress to sever all but the closely knit systems was considered.

North American contended that it had consistently handled all of the financing matters of its subsidiaries, particularly the flotation of securities. The subsidiaries claimed that they would be unable to perform such functions without incurring large additional expenses incident to the employment of financial talent. The Commission pointed out that the major subsidiaries of North American were so large that it would not be inappropriate in any event for them to have their own finan-

\footnotetext{
${ }^{247}$ Republic Electric Power Corporation, 3 S.E.C. 992 (1938).

${ }^{245}$ American Water Works \& Electric Company, 2 S.E.C. 972 (1937).

${ }^{243}$ The North American Company, I I S.E.C. 194 (1 942).

${ }^{250}$ H.R. Report No. 1903, 74th Cong., Ist Sess. (1935), p. 71.
} 


\section{I38 PUBLIC UTILITY HOLDING COMPANIES}

cial experts. Further, if the various subsidiaries were permitted to do their own financing and were freed from the restrictions imposed by the holding company, the local officials could soon become familiar with the problems involved, and could manage the financial negotiations themselves. The Commission held that North American had not shown that such financing could not have been done, and done without the loss of substantial economies, without North American's participation. North American advanced another argument along this line to the effect that it had made substantial advances to its subsidiaries over the years and therefore constituted an important source of financing. The Commission replied to this by pointing out that North American had made no advances to subsidiaries since 1935 , that the interest rates paid by the subsidiaries were high $\left(4 \frac{1}{2} \%\right.$ to $\left.81 / 8 \%\right)$, and that North American had borrowed considerable sums from its subsidiaries for the purpose of lending the money in the call-money market. North American generally paid interest to its subsidiaries at a rate lower than the current call-money rates. The first postulate stated above was therefore not complied with.

North American further claimed that a loss of substantial economies would result from severance, because the staff of North American furnished the various subsidiaries with advisory and consultative facilities with respect to budgeting, tax matters, major installations, and accounting matters. This contention was rejected by the Commission because of the limited facilities furnished by North American. Its staff consisted of only eight persons, including three clerks, two engineers, a rate specialist, and two executives.

The various North American subsidiaries were represented on three system committees which served as a clearing house for technical and accounting information. The record indicated that the operation of these committees had been of some 
benefit to the participating companies. It was testified that the committees could not survive a rupture in the affiliated status of the member companies. The Commission could not understand why such committees could not be retained after severance if they were so valuable, and thought that their dissolution would only be proof of the insubstantiality of the "economies" resulting from them.

Consequently, the Commission found that the requirements of Clause A had not been met with respect to the WisconsinMichigan or the Detroit properties of The North American Company system. ${ }^{251}$ However, it was found that four small but individually integrated electric utility properties in Illinois could not be operated without the loss of substantial economies which could be secured by their retention under joint control together with the principal electric system of Illinois Power Company and Kewanee Public Service Company. ${ }^{252}$

The same contentions as those discussed above were urged upon the appeal of this case. The Circuit Court of Appeals for the Second Circuit affirmed the action of the Commission relative to Clause $A$, pointing out that whether economy was achieved by centralized control was always a doubtful question and one peculiarly fitted for decision by an administrative agency staffed by experts. ${ }^{253}$ On such an issue the court was of the opinion that it could not review or reweigh the evidence. ${ }^{254}$ The court further asserted that it was in accord

${ }^{251}$ The North American Company, i I S.E.C. 194, 208 (1942).

${ }^{202} I d$. at 243-244. See map of The North American Company system at page 45 , supra.

${ }^{25 s}$ The North American Company v. Securities \& Exchange Commission, 133 F.(2d) 148 (C.C.A., 2d Cir., 1943). Certiorari was granted by the Supreme Court, but the decision by that court did not pass upon matters of statutory interpretation and was limited to the constitutional issue. The North American Company v. Securities \& Exchange Commission, 327 U. S. 686 ( 1946$)$.

${ }^{254}$ See Morgan Stanley \& Co. v. Securities \& Exchange Commission, 126 F.(2d) 325 (C.C.A., 2d Cir., 1942). 
with the Commission's ruling that the words "substantial economies" in Clause A meant "important economies."

In the original North American Company decision, the retainability of the integrated gas utility properties of the St. Louis County Gas Company as a system additional to the integrated electric properties of Union Electric Company of Missouri was not determined. ${ }^{255}$ In view of the submission by North American of a plan for compliance with Section I I, which called for the liquidation of its interest in County Gas, the Commission withheld its decision on this point for several years. However, in 1945 the Commission decided to pass upon the question, because of certain proposed inter-system exchanges with the Ogden Corporation. ${ }^{256}$

The area served by the gas facilities of County Gas lay entirely within the territory served by Union with electricity, and many of its customers were served by both companies. Both had the same top executive officers and board of directors, and maintained the same general offices. Both shared several branch offices and certain storage facilities, and numerous operations were jointly conducted, such as customer services (meter service, billing, connection and disconnection of facilities), use and purchase of general equipment, and general supervision and management. Such joint provision of services was the principal basis of North American's claim that substantial economies would be lost if County Gas were severed from the North American system. Stress was also laid on the savings to County Gas resulting to the filing of consolidated returns with North American.

North American contended that independent operation of these two systems would result in additional expenses to Union amounting to $0.14 \%$ of its gross operating revenues for 1942 and $0.26 \%$ of its operating expenses for the same

${ }^{255}$ The North American Company, I I S.E.C. I 94 (1 942).

${ }^{28 B}$ The North American Company, 18 S.E.C. 6I I (1945). 
year; and further contended that there would be additional expenses to County Gas amounting to $6.68 \%$ of its gross operating revenues and $8.43 \%$ of its operating expenses for I942. To this should be added the savings alleged to result in favor of County Gas from the filing of joint tax returns, amounting to approximately one-third of the latter percentages. It was also claimed that it would cost an amount equal to approximately one-sixth of the percentages applicable to County Gas to effect the separation. And finally, it was asserted that there should be included in the estimates of lost economies the savings to joint customers in postage, fares and trouble, by reason of the single management respecting the gas and electric services.

The assertion of "economies" resulting from tax savings was disposed of quickly. The Commission referred to its decision in the Cities Service Company case, wherein it was pointed out that such "economies" had no relation to operational factors and depended solely upon the accidents of ownership and the state of tax legislation at a given time. ${ }^{257}$ The Commission stated its position as follows:

". . . We think the staff is correct in its position that the claimed tax savings cannot be indiscriminately included in an estimate of lost economies under clause (A). Where, as here, the question is whether naturally competitive utilities should be permitted to remain under common control the tax savings, if considered at all, must be regarded as a minor factor. ${ }^{\text {258 }}$

It was further the opinion of the Commission that the initial expenses of effecting segregation and the inconvenience to customers, although not to be disregarded, assumed their proper place only in the light of peculiar problems of the

${ }^{257}$ Cities Service Company, I 5 S.E.C. 962 ( 1944 ).

${ }^{258}$ The North American Company, 18 S.E.C. 6ri, 614-6I's (1945). 


\section{PUBLIC UTILITY HOLDING COMPANIES}

case. For example, if the initial segregation expense were prorated over the life of the assets being separated, the resulting annual figure would be insignificant. And also, customers' expenses should be weighed, according to the Commission, against customer benefits to be achieved from separation.

Relative to the claimed increases in annual expenses resulting from separation, the Commission first pointed out that such expenses were overstated by certain amounts representing capital expenditures, thereby reducing the ratio of the additional expenses of County Gas to its gross operating revenues and operating expenses of 1942 to $5.87 \%$ and $7.43 \%$, respectively.

Considerable emphasis was placed by the Commission on the rule of intangible benefits upon separation enunciated in prior decisions. "The benefits of terminating widespread control, subtle and apparent, must be considered as offsets to the claims of lost economies. Only the balance, though it may be inexpressible in money terms ... can form the basis of decision," according to the Commission. ${ }^{260}$ It was pointed out that here the electric and gas businesses, operating in the same territory, were competitors in numerous instances, and that the natural tendency of joint control was to favor the business that was most profitable. Examples of similar problems arising before state utility commissions were cited. ${ }^{261}$

${ }^{289}$ The North American Company, 1 I S.E.C. 194 ( 1942 ); Engineers Public Service Company, I 2 S.E.C. 41 (1942); Cities Service Power \& Light Company, I4 S.E.C. 28 (I943); and Cities Service Company, I 5 S.E.C. 962 ( 1944 ). The last three cases cited will be discussed in detail below.

${ }_{200}$ The North American Company, 18 S.E.C. 6II, 615 (1945). Also see The North American Company, Release No. 10320 (December 28, 1950).

${ }^{201}$ In Twin State Gas \& Electric Company, 25 N.H.P.S. Comm. Rep. 277 (1 943), the New Hampshire Commission stated:

"This Commission has viewed acquisition of gas utilities by utilities primarily interested in electricity with some concern. Accordingly, although the transfer of gas properties is from one electric utility to another, we made inquiry into operating policies to be followed. Exhibits showing operating comparisons between such controlled gas utilities and all inde- 
In connection with the problem involving the existence or lack of economies resulting from the joint operation of electric and gas utility systems, from the point of view of the gas system, the staff of the Public Utilities Division of the Commission had prepared a statistical study which first became available to the Commission in this case. It was noted that the burden of proof did not lie with the staff, but that in any event the Commission desired to have an ample record, notwithstanding the legal situs of the burden of proof. Further, certain weaknesses of statistical comparison, such as insufficient samples, were recognized. The staff had studied the operations of 65 companies for the year 194I, including 39 companies serving gas exclusively and 26 combination

pendent New Hampshire gas utilities were submitted of record. These comparisons show that in independent gas utilities over the last ten-year period, the loss in customers was one percent, while for Public Service gas utilities the loss was I I.5 percent, and for Twin State, I 9 percent. Corresponding gas consumption loss percentages over the same period were $4.9,24.2,41.5$ percent, respectively.

"At least some doubt is raised as to whether the effort of electric utilities is toward maintaining gas sales or discouraging such sales. For instance, the net costs of 'Twin State's new business effort in 1942 was $\$ 4.09$ for gas and $\$ 12,950.30$ for electricity in the Dover Division. The Vice-President testified that this was all the expenditure warranted by the gas business. ...

"There is little in this record to indicate that there are advantages in permitting an electric utility to operate a gas utility. Rather, there appears to be some loss of the competition between the two industries, a situation which is repugnant to the State Constitution. It would seem that management, favored wtih a monopoly in the products of competing industries, must make certain that competition is actually and actively maintained if it is not to be viewed with suspicion."

The Montana Commission in the case of Helena Light \& Railroad Company, P.U.R. I $920 \mathrm{D}, 668$, made the following comments relative to joint ownerships of electric and gas facilities:

"It is almost superfluous to say that the evident inertia of the gas service, its deteriorated plant and relatively failing patronage result immediately from the fact that it has it has no competition. Its natural competition, the electric utility, being owned by the same company, favored by the management and enjoying certain popular advantages, has snuffed out the spark of incentive to increased business and improved service. The Company is indifferent to better gas service because its failure in this department results in gain to the electric department, whereas an independent gas entrepreneur would strive to occupy the electric field." 
companies serving both gas and electricity. Pertinent excerpts from this statistical study are set forth below. ${ }^{262}$ Substantially favorable items, from the Commission's point of view, are denoted by an asterisk.

The staff's studies, including the foregoing and other data, indicated to the Commission that, in comparison with combination companies, (a) gas companies tended to sell more gas and derive more revenue per customer at smaller prices per therm; (b) companies serving electricity alone tended to sell more current and derive more revenue per customer at lower prices per $\mathrm{KWH}$; (c) while customer accounting and

\section{TABLE I}

Comparison of Sales: Gas Companies, Electric Companies and Combined Electric \& Gas Companies

\begin{tabular}{lccc}
\hline & $\begin{array}{c}\text { Mean Therms } \\
\text { or KWH Per } \\
\text { Customer }\end{array}$ & $\begin{array}{c}\text { Mean Revenue } \\
\text { Per Customer }\end{array}$ & $\begin{array}{c}\text { Average Cents } \\
\text { Per Therm } \\
\text { or KWH }\end{array}$ \\
\hline $\begin{array}{l}\text { Natural Gas: } \\
\text { Gas Companies }\end{array}$ & 586 & $\$ 40.26$ & 6.87 \\
Combination Companies & 434 & 38.58 & 8.89 \\
$\begin{array}{l}\text { Manufactured Gas: } \\
\text { Gas Companies }\end{array}$ & 157 & 32.48 & 20.69 \\
Combination Companies & 148 & 31.91 & 21.56 \\
Electricity: & & & \\
Electric Companies & 1012 & 37.05 & 3.66 \\
Combination Companies & 882 & 35.69 & 4.05 \\
\hline
\end{tabular}

TABLE II

Comparison of Fiscal, Managerial and Distribution Expenses

\begin{tabular}{lcc}
\hline & $\begin{array}{c}\text { Mean } \\
\text { Combination } \\
\text { Companies }\end{array}$ & $\begin{array}{c}\text { Mean Gas } \\
\text { Companies }\end{array}$ \\
\hline Expense per Customer: & & \\
Customer Accounting and Collection & $\$ 1.91^{*}$ & $\$ 2.34$ \\
Administrative and General & $2.71^{*}$ & 2.97 \\
Distribution & 4.48 & 4.03 \\
\hline
\end{tabular}

These tabulations are shown in The North American Company, 18 S.E.C. 611 at $618-620$ (1945). 
TABLE III

Comparison of Residential Sales

\begin{tabular}{|c|c|c|c|}
\hline & $\begin{array}{c}\text { Mean } \\
\text { Combination } \\
\text { Companies }\end{array}$ & $\begin{array}{l}\text { Mean Gas } \\
\text { Companies }\end{array}$ & $\begin{array}{c}\text { County } \\
\text { Gas }\end{array}$ \\
\hline $\begin{array}{l}\text { Including House Heating: } \\
\text { Sales per customer } \\
\text { (therms) } \\
\text { Revenue per customer } \\
\text { Revenue per therm sold }\end{array}$ & $\begin{array}{l}287.40 \\
\$ 35.48 \\
15.46\end{array}$ & $\begin{array}{c}330.04 \\
\$ 35.96 \\
15.52 \phi\end{array}$ & $\begin{array}{r}366.88^{*} \\
\$ 40.43^{*} \\
11.02 \downarrow\end{array}$ \\
\hline $\begin{array}{l}\text { Excluding House Heating: } \\
\text { Sales per customer } \\
\text { (therms) } \\
\text { Revenue per customer } \\
\text { Revenue per therm sold }\end{array}$ & $\begin{array}{c}144.33 \\
\$ 27.02 \\
19.64 \phi\end{array}$ & $\begin{array}{c}166.64 \\
\$ 30.47 \\
20.07 \&\end{array}$ & $\begin{array}{l}158.56 \\
\$ 23.65 \\
14.926\end{array}$ \\
\hline
\end{tabular}

TABLE IV

Study of Typical Monthly Gas Bills for Residential Service

\begin{tabular}{|c|c|c|c|}
\hline & $\begin{array}{c}\text { Combination } \\
\text { Companies }\end{array}$ & $\begin{array}{c}\text { Gas } \\
\text { Companies }\end{array}$ & $\begin{array}{c}\text { County } \\
\text { Gas }\end{array}$ \\
\hline $\begin{array}{l}\text { Cooking: } \\
5 \text { Therms Mean } \\
\text { Median } \\
10 \text { Therms Mean } \\
\text { Median }\end{array}$ & $\begin{array}{r}\$ 1.06 \\
1.10 \\
1.89 \\
1.92\end{array}$ & $\begin{array}{r}\$ 1.06 \\
1.05 \\
1.78 \\
1.84\end{array}$ & $\begin{array}{l}\$ .93^{*} \\
1.55^{*}\end{array}$ \\
\hline $\begin{array}{c}\text { Cooking and Water Heating: } \\
15 \text { Therms Mean } \\
\text { Median } \\
25 \text { Therms Mean } \\
\text { Median }\end{array}$ & $\begin{array}{l}2.67 \\
2.79 \\
3.91 \\
4.14\end{array}$ & $\begin{array}{l}2.31 \\
2.62 \\
3.51 \\
3.71\end{array}$ & $\begin{array}{l}2.18^{*} \\
3.42^{*}\end{array}$ \\
\hline $\begin{array}{c}\text { Cooking, Water Heating, and Re- } \\
\text { frigeration: } \\
35 \text { Therms Mean } \\
\text { Median }\end{array}$ & $\begin{array}{l}5.13 \\
5.54\end{array}$ & $\begin{array}{l}4.63 \\
4.71\end{array}$ & 4.67 \\
\hline $\begin{array}{c}\text { Cooking, Water Heating, Refrig- } \\
\text { eration, and House Heating: } \\
\text { 100 Therms Mean } \\
\text { Median } \\
250 \text { Therms Mean } \\
\text { Median }\end{array}$ & $\begin{array}{c}10.23 \\
9.90 \\
21.32^{*} \\
20.65^{*}\end{array}$ & $\begin{array}{r}9.75 \\
9.58 \\
21.51 \\
21.67\end{array}$ & 19.88 \\
\hline
\end{tabular}

collection, and administrative and general expenses per customer tended to be higher for gas companies than for combination companies, distribution expenses per customer tended 


\section{I46 PUBLIC UTILITY HOLDING COMPANIES}

to be lower; (d) gas companies tended to derive vastly higher revenues from merchandising and jobbing; (e) gas companies tended to sell more gas for residential purposes, derived more revenue per customer and per therm sold whether house heating load was included or excluded, their performance being better when it was excluded; and ( $f$ ) gas company rates for residential service tended to be lower for all brackets except that of 250 therms, and in that bracket tended to be only slightly higher. It might well be added that in several instances where the performance of the combination companies was not as favorable as that of the gas companies, the performance of County Gas was better than both. The Commission was convinced, however, that the expansion of County Gas's electric sales and revenues was taking place at the expense of the gas business, remarking that "To expect vital competition between the two types of service when controlled by the same interests is, in our opinion, highly unrealistic."263 The conclusion was that County Gas was not retainable for the reason that it had not been shown that substantial economies would be lost, within the meaning of Clause A, if County gas were severed from North American control. It was pointed out that new operating alliances and resulting economies were in prospect by virtue of the proposed integration of the gas utility facilities of County Gas and Laclede Gas Light Company, which served gas in contiguous territories.

This decision obviously sets forth a very carefully considered opinion relative to the requirements of Clause $\mathrm{A}$. The staff of the Public Utilities Division is to be commended for its research into the various state proceedings involving similar problems and for its statistical survey comparing joint

${ }^{283}$ The North American Company, 18 S.E.C. 6II, 621 (1945). Also see Cities Service Power \& Light Company, I4 S.E.C. 28 (1943), and The Commonwealth \& Southern Corporation, Release No. 76 I 5 (August I, 1947). 
electric and gas operations with independent gas operations. The solution, of course, can never become a scientific matter, but this case marked a radical departure from the somewhat haphazard approach to the requirements of Clause A evidenced in prior decisions, a number of which are discussed below. In many cases the Commission has relied on the proposition that the intangible benefits resulting from the separation of gas and electric facilities offset or outweighed tangible benefits from joint operation actually proved by the utility in question. The North American decision of 1945 was the first legitimate attempt made by the Commission to substantiate its proposition. Although the inherent weaknesses of statistical comparison must be recognized, especially where the period of time covered and the samples included are limited, it can be said that the Commission made out a good case for itself.

\section{Engineers Public Service Company}

An early case involving the application of Clause A of Section I I (b) (I) was that of Engineers Public Service Company. ${ }^{264}$ The question arose whether the gas utility system of Virginia Electric \& Power Company was retainable as an additional system to the electric utility system of the same company. Engineers claimed that substantial economies in the operation of both the gas and electric systems would be lost if common control of these properties was terminated. The economies asserted amounted to $\$ 7 \mathrm{I}, 500$ in the operation of the gas system and $\$ 56,000$ in the operation of the electric system. ${ }^{265}$ These economies came largely from savings in the

${ }^{24}$ See map of Engineers Public Service Company electric utility system, supra, page 42 .

${ }^{203}$ The Public Utility Division of the Securities \& Exchange Commission took the position that the "loss of substantial economies" in Clause A referred exclusively to economies lost to the additional system, and Engineers contended that the clause referred to economies lost to both the principal system and the 


\section{PUBLIC UTILITY HOLDING COMPANIES}

form of salaries which, upon separation, would either be paid to additional personnel or, instead of being shared, as in the past, would be borne by one system or the other. The Commission viewed these items as follows:

“... In prescribing the conditions under which additional systems may be retained, however, Congress did not speak in terms of increased expenses. It authorized the retention of additional systems if they could not be operated independently without the loss of substantial economies. And in measuring the loss of economies accompanying the severance of a combination of two utility systems it is particularly important to consider the beneficial effects of independent ownership upon the efficient operation of each system. A consideration of increased expenditures alone does not adequately reflect the impact of severance upon the two systems. Where, as here, gas and electric operations are conducted in the same territory and in many ways compete with each other, the danger exists that under a single management one business may be suppressed in favor of the other or that one will bear burdens properly allocable to the other. The record before us shows, for instance, that there have been abuses in allocating expenses between gas and electric properties. Not only has there been a failure to allocate or separate the expenses of many specific items, but there has been an over-all erroneous allocation. Thus, prior to 1933, expenses were allocated between Virginia's departments in the ratio which the gross revenues from each bore to the total. After that year they were allocated on a net

additional system. The Commission did not here decide this issue, and assumed for the sake of argument that the latter interpretation was correct. Engineers Public Service Company, I2 S.E.C. 4I (1 942). The interpretation of the Public Utilities Division was upheld by the Court of Appeals for the District of Columbia in Engineers Public Service Company v. Securities \& Exchange Commission, 138 F.(2d) 936 (C.A.D.C., 1943 ). 
revenue basis, the prior year's revenues furnishing the annual yardstick for the current year's allocation. The effect of this change was to increase the expenses allocable to the electric department and to decrease the expenses allocable to the gas department. Neither method of allocation bore any relationship to the actual expenses involved. . . . The impropriety of the ... allocations, however, as the respondents admit, has in the past affected the rate structures of the gas and electric operations. It is true that respondents propose to attempt to correct these practices. But that these abuses can most effectively be eliminated by complete severance is unquestionable. Moreover, the possible benefits of unsuppressed development and growth for each business must also be cast in the balance when substantial economies are measured. The economies which may be expected from a personnel single-mindedly devoted to the operation of either a gas or an electric business, although not predictable in precise mathematical form, cannot be ignored." 268

Further, the Commission found that the increased expenditures anticipated by Engineers were excessive. The need for additional employees for customers' accounting and collection work, advertising and sales promotion, and in executive departments was questioned. The conclusion was that, with respect to the gas properties alone, the record would not sustain a finding of more than one-half of the claimed increased expenses, and that the loss of economies would in fact be less than such increased expenses. Holding that the requirements of Clause $\mathrm{A}$ had not been met in this case, the Commission stated:

“... Since this requirement (relative to the retention of additional systems) is an exception to a clearly ex-

${ }^{268}$ Engineers Public Service Company, I2 S.E.C. 4 I, 57-58 (1942). 
pressed general policy, it must be strictly construed. Moreover, in determining what are substantial economies, we must bear in mind that Congress was informed that some loss of economies of the sort principally involved in this situation-in joint administrative, clerical and supervisory services and the use of joint facilitiesalmost invariably would accompany separation of jointly controlled utility systems. Against this background we must require clear and convincing evidence of a loss of economies which would seriously impair the effective operations of the systems involved in order to permit the retention of an additional system..2667

Upon the appeal of this case, it was pointed out that the claimed economies which would be lost by severance of the gas and electric systems were in two classes: (I) actual expenses previously allocated to the gas property which would have to be paid by the electric properties even after separation; and (2) increased cost of operations of the gas properties as independent businesses. The economies in the first class were chiefly caused by the joint use of personnel and property; the economies in the second class were arrived at by comparing the previous costs of operation allocated to the gas properties with the estimated cost of an independent gas system. The Court of Appeals thought that "substantial economies" meant something more than substantial savings in operational expenses, although the latter was one element of the former. The Court adverted to the decision in The North American Company case, ${ }^{268}$ and pointed out that "substantial economies" meant "important economies." The Court

${ }^{207}$ Engineers Public Service Company, I2 S.E.C. 41, 60-6r (1942). See House Hearings on H.R. 5423, 74th Congress, Ist Sess., Part 2, pages 1249 , 1402-3, $1530-31$; Part 3, pages 2257-2277 (1935); and Senate Hearings on S. I 725, 74th Congress, ist Sess., page 65 (1935).

${ }^{208}$ The North American Company v. Securities \& Exchange Commission, 133 F.(2d) 148 (C.C.A., 2d Cir., 1943). 
agreed with the Commission that there were definite benefits to be derived from the separation of two competitive businesses. The Court of Appeals was of the opinion that Engineers had the burden of proving the following items in this connection: (a) that there would be a continuing substantial strength, enjoyed by the controlled company, which it would not have under its own control; (b) that there would be in the situation no reasonable expectation that a compensating strength would not be enjoyed by reason of its own control; and (c) that such continuing strength would not entail a sacrifice upon the part of the controlling utility. Consequently, the ruling of the Commission was upheld. ${ }^{269}$ The statutory basis of the "strength" requirements was not explained by the court. These requirements were essentially judicial legislation.

The heavy burden thus placed upon the party urging retention was justly criticized in the minority opinion in the Engineers case. ${ }^{270}$ The approach of the majority and of the Commission was that the "ABC" clauses constituted an exception to the general policy of the Act to break up large combinations of utilities, and therefore they were to be applied only in exceptional circumstances. The theory of the dissenting opinion was that Congress would not have passed the Act without the "ABC" clauses, therefore evidencing a desire to prohibit the unnecessary disturbance of existing conditions. The difference between the majority and the minority was consequently one of emphasis. The dissenting judge felt that substantial savings in operational expenses amounted to "substantial economies," and that it was putting it too strongly to say, as the Commission did, that there must be clear and

${ }^{269}$ Engineers Public Service Company v. Securities \& Exchange Commission, 138 F.(2d) 936 (C.A.,D.C., 1943 ).

${ }^{270}$ Engineers Public Service Company v. Securities \& Exchange Commission, 138 F.(2d) 936 (C.A.,D.C., 1943 ). 
convincing evidence of loss of economies which would seriously impair the efficiency of the system. The dissenting judge argued that this was so because the Act did not require more than a preponderance of the evidence to support such a finding, and because the loss of economies which would seriously impair the system would not merely be substantial but also destructive. It was his opinion that a loss of substantial economies occurs if the loss is so large that experienced men of affairs would regard it as substantial and, if possible, take steps to eliminate it. He further felt that an annual loss of $\$ 91,730$, which the Commission had recognized to be probable in this case, would meet this test. In addition, he thought that there were probably further savings not considered by the Commission. And finally, he rejected the conjecture of the Commission that compensating advantages might result from separate management for the reason that it was entirely without support in the evidence.

The approach of the dissenting opinion to this problem may perhaps not be entirely sound. Certainly if the Commission had taken the position that the status quo was not to be disturbed unless absolutely necessary, as the dissent implies, the course of the integration program would have been far different. This was the essence of the holding company bill originally passed by the House and later revised. It may well be conceded that this view constitutes too narrow an interpretation of the intent and purposes of the Act. Nevertheless, there is much to be said in favor of the approach of the dissent to the practical problems involved. The Commission was quick to reject many of the loss estimates in the early decisions and did not take time to analyze the rejected figures to see if they were improper in whole or only in part. The Commission also relied strongly upon its postulate that there would be compensating advantages resulting from separation. Such is the basic theory of the Act, but it is difficult to meas- 
ure such intangibles, although an attempt in this direction was made in the 1945 North American case, discussed above. Since the purpose of the Act is to require separation, the burden of proof is placed upon the party seeking retention under the enumerated exceptions to the Act. The interpretation of the Commission and of the majority of the Court of Appeals discussed here not only saddles such a party with the burden of proof, but increases such burden by attributing a substantial, though indefinite, monetary value to the results to be achieved through separation.

Engineers contended that the electric utility system of Savannah Electric \& Power Company was retainable as an additional system to that of Virginia Electric \& Power Company. Engineers calculated that economies to be lost by a separation of these two systems would amount to $\$ 28,000$ for each company. The Commission observed that this amount represented increased expense principally for advice with respect to taxes, accounting, procurement, etc., which was not necessarily equivalent to lost economies, and which did not take into consideration any improvements in service or efficiency or other benefits that might result from severance, and further that Congress was aware that in the normal course of events certain economies, such as those involved here, could be obtained by common control. The figures submitted by Engineers represented $.3 \%$ of Virginia's 1940 electric operating expenses and $2.2 \%$ of Savannah's, or $.7 \%$ of Virginia's net income and 5.5\% of Savannah's. The Commission held that these amounts did not constitute "substantial economies" under the standards of Clause A. ${ }^{271}$ Also, it was pointed out that Engineers' figures were not to be taken as correct, since they included economies in the operation of Savannah's transportation properties which were not retain-

${ }^{271}$ Engineers Public Service Company, 12 S.E.C. 4 I (1942). 
able and since the Commission was not convinced that as many additional expert employees would be required as estimated by Engineers. It was pointed out that many of the functions for which Engineers contemplated needing new employees could be efficiently performed by members of the current executive staffs of each operating company.

It was further proposed by Engineers that the natural gas system of Gulf States Utilities Company in Baton Rouge, Louisiana, should be retainable as an additional system to Gulf's electric utility system. The evidence indicated that the increased costs to the gas system in the event of separation would be $\$ 42,024.00$ and the increased costs to the electric system would amount to $\$ 52,452.00$, a total of $\$ 94,476.00$. To the electric department this would result in increased expenses of less than I\% and a net loss of $2.3 \%$, which the Commission did not regard as substantial. The asserted losses to the gas system amounted to $8.7 \%$ of its operating expenses and $32.6 \%$ of its net income for I940. Obviously, these amounts were substantial, but the Commission was of the opinion that Engineers' estimate of the additional executives and employees that would be necessitated by a division was overstated by a substantial amount. Other costs, such as those for office, garage, and shop facilities, were considered to be excessive. The question was raised, but not settled, whether lost economies attributable to the operation of a gas merchandising and jobbing business, retainable as "other businesses," could be considered in connection with Clause A. A negative answer was indicated. In the light of all these considerations, the Commission held that the economies to be lost through separate operation of the gas and electric systems of Gulf were not substantial, and therefore that the requirements of Clause $A$ were not met. ${ }^{272}$ The opinion of the Commission 
is open to considerable criticism in view of the fact that it resorted to generalizations to destroy the validity of the substantial amounts adduced in evidence by Engineers, and in no instance did it indicate even approximately the percentage or amount of error existing in Engineers' figures.

The decision of the Commission with reference to the Gulf electric and gas properties was affirmed on appeal. ${ }^{273}$ However, the dissenting opinion took issue with this holding. ${ }^{274}$ It was stated that the Commission had held that $\$ 25,000.00$ of the $\$ 42,024.00$ asserted additional costs to operate a separate gas system had been proved, although such amount does not appear in the reported opinion of the Commission. This amount was added to the $\$ 52,000.00$ additional cost to the electric system asserted by Engineers, a total annual loss of $\$ 77$,000.00. It was pointed out that the I 940 gross receipts for the gas business were approximately $\$ 720,000$, and the property account was $\$ 1,675,000$, compared with $\$ 10,840,000$ and $\$ 57,770,000$, respectively, for Gulf. The propriety of adding the electric system losses to the gas system losses when comparing lost economies with the gross receipts and property account of the gas system alone is, of course, doubtful; and such losses, even if properly combined, were not substantial in comparison with the electric system receipts and property account. It was the opinion of the dissenting judge, however, that the Gulf gas system was retainable as an additional system.

Engineers also sought to retain the El Paso Electric Company properties as an additional system to the Gulf electric system, asserting savings of $\$ 50,700.00$ annually in the operation of the two companies, $\$ 12,000.00$ of which

${ }^{273}$ Engineers Public Service Company v. Securities \& Exchange Commission, 138 F. (2d) 936 (C.A.,D.C., 1943 ).

${ }^{274}$ The dissent appears as part of the majority opinion, but it is in actuality a continuation of the minority opinion on the retention of the Virginia gas system as an additional system. 


\section{I56 PUBLIC UTILITY HOLDING COMPANIES}

was allocable to Gulf, $\$ 32,800.00$ to $\mathrm{El}$ Paso, and the remainder to the Baton Rouge Bus Company. These savings were computed by subtracting from the estimated cost of providing assertedly necessary supervisory assistance and services to both companies, if independent, the estimated cost of these services if the companies were under common control. As in the case of Virginia and Savannah, these savings occurred not in the physical, day-to-day operation of the properties, but largely in the administrative, accounting, and financial conduct of the business. The loss of economies claimed represented $.5 \%$ of Gulf's net and $.3 \%$ of Gulf's gross income from electric operations in 1940, and $7.4 \%$ of El Paso's net and 3.6\% of its gross income from electric operations. Or these claims would have resulted in an increase in operating expenses of .2\% to Gulf and $\mathrm{I} .8 \%$ to $\mathrm{El} \mathrm{Paso.}$ These amounts were held to be inadequate to meet the requirements of Clause $A{ }^{275}$

The Commission was further of the opinion that the economies resulting from common control in this case were not in fact as substantial as those claimed. The estimates included savings in the operation of non-retainable transportation properties which could not be considered in this regard, and the Commission rejected the contentions that all of the proposed additional executive assistance was necessary and that none of the functions to be performed by such experts could be efficiently performed by the existing executives. Also, the cost of obtaining the additional services claimed to be necessary was found to be less than the amount claimed. The conclusion was clear that the economies, if any, which would be lost upon the separation of these two electric utility systems were not such as would justify the retention of El Paso by Engineers along with Gulf under the standards of Clause A.

${ }^{27 s}$ Engineers Public Service Company, 12 S.E.C. 4 I (1942). 
In addition to its principal integrated electric utility system, El Paso Electric Company owned and operated another small but integrated electric system serving the town of Van Horn, Texas. It was stated by the Commission that "material savings" were effected by the combination of El Paso and Van Horn, and that substantial economies would be lost if the two systems were separated. ${ }^{276}$ The requirements of Clause $\mathrm{A}$ were therefore met in this instance, although the opinion does not give enough of the details to be of much value in this study of Clause A. It is likely that the Commission was influenced by the fact that the small Van Horn system would become an undesirable orphan if separated from El Paso.

\section{Cities Service Power E Light Company}

The numerous integrated utility systems within the Cities Service Power \& Light Company empire have previously been defined. ${ }^{277}$ In addition to these integrated systems, Cities desired to retain various other systems operated in conjunction with those found to be integrated. It was shown that the natural gas operations of Toledo Edison Company, whose electric operations had been found to be integrated, were carried on by some of the same employees engaged in the electric operations with resulting economies, the amount of which is not shown. Further, there was testimony to show that by reason of the common electric and gas franchise, it would be difficult or impossible to dispose of the gas properties without at the same time disposing of the electric properties. The Commission held that further proof should be adduced upon this point, but indicated that if it were impossible to separate the enterprises for franchise reasons, or if it were necessary to abandon the gas operations to comply with an ${ }^{276}$ Ibid. supra.

${ }^{277}$ See map of Cities Service Power \& Light Company systems, page 52, 
integration order, such facts might be relevant to a determination of whether separation could feasibly be ordered; or in other words, such facts might indicate compliance with Clause $A .^{278}$

Cities sought to retain the integrated electric utility system of St. Joseph Railway, Light, Heat \& Power Company with the Mid-Continent system of properties. It was estimated that an annual increase of $\$ 76,865$ in general and administrative expenses would be necesary to maintain the St. Joseph company outside the Cities Service system. The theory behind this estimate was that the St. Joseph company would have to supply itself independently with the benefits then received from the system service company, and would need additional personnel, such as an executive vice-president and assistant general manager, an assistant secretary and local auditor, and advertising, promotional, and purchasing personnel, a budget director, and an engineer. The increased expenses amounted to $2.67 \%$ of average operating revenue for 1939-1940, or $5.23 \%$ of average total operating expenses for the same period. The Commission was of the opinion that the estimates were unduly high. It further held that Cities Service had not considered the intangible benefits resulting from separation, discussed above, and stated its views in this manner:

"... One of the cost items (significant, though sometimes difficult of isolation) of operating subsidiaries in a large holding company system, is the cost of maintaining a holding company in some remote center, and the hazard of having operating policies dominated by persons whose interest is not that of any particular company or service area, but the most profitable possible

${ }^{278}$ Cities Service Power \& Light Company, I4 S.E.C. 28 (1943). Compare the cases where it is stated that difficulty of disposition has no bearing on whether or not a disposition order should be entered. Associated Gas \& Electric Corporation, I I S.E.C. I I 5 ( I 942); The North American Company, I I S.E.C. 194 ( 1942$)$. 
operation of a vast system. That cost is, in our opinion, always a necessary deduction from any estimate of increased expenditures occurring upon separation from a holding company system. The economies that must be lost to warrant retention under Clause (A) must be 'substantial.' Even crediting the conclusions of respondents, we cannot find that the increased operating expenses are so great as to require a finding that important economies would be lost to the St. Joseph company by separation from the Power \& Light system. Any duplication of effort created by compliance with Section I I (b)(I) is estimable as a loss. Congress intended, however, that the loss, anticipated for all systems undergoing the processes of Section II(b) (I), should outweigh the benefits of independence. ... As we have indicated, not only are these estimates inflated, but benefits to the St. Joseph properties from the elimination of their share in the cost of maintaining the Power \& Light Company must be considered. ..."279

Cities Service wished to retain certain gas operations located in the Mid-Continent area, and in this connection adduced evidence to show the joint use of facilities by the gas and electric businesses. Such facilities consisted of automotive equipment, a meter shop, and the central office. Meter reading, customers' accounting, and billing were jointly handled for both businesses. It was estimated that separation of the electric and gas departments would result in increased costs for both businesses, totaling $\$ 45,749 \cdot 34$. This evidence was considered insufficient to show compliance with Clause A. ${ }^{280}$

Cities Service contended that if Rawlins Electric Company were operated separately from the Rocky Mountain

${ }^{279}$ Cities Service Power \& Light Company, 14 S.E.C. $28,47-48$ (1943). See Engineers Public Service Company, 12 S.E.C. 41, 57-58 (1 942).

${ }^{280}$ Cities Service Power \& Light Company, I 4 S.E.C. 28 (1943). 
properties, there would be an annual increase in general and administrative expenses of $5 \%$ of the average gross operating revenues of the company for the years 1939 and 1940 , and an increase in average total operating expenses for the same years of I I \%. The Commission did not accept these estimates as correct, however. The opinion pointed out that functionally the Rawlins properties formed a part of the U. S. Bureau of Reclamation system in the Wyoming area, rather than part of the Cities Service system. The physical relationship of the Rawlins properties with the remainder of the group properties in the Rocky Mountain area was extremely tenuous, and was an incidental result of the fact that other group properties shared in the U.S.B.R.'s power sources. Recent major benefits to the Rawlins properties resulted not from connection with the holding company system, but rather from physical interconnection with the government-owned and operated facilities. The conclusion was that the requirements of Clause $\mathrm{A}$ were not met in this instance. ${ }^{281}$

The Rocky Mountain group of Cities Service properties included a considerable number of gas properties, principally natural gas distribution systems. The decision as to the retainability of these systems was withheld in most instances to allow Cities Service to adduce further evidence. However, the Commission did order the disposition of the manufactured gas operations of the company in Grand Junction, Colorado. ${ }^{282}$ These manufactured gas operations were small and unprofit-

${ }^{281}$ Ibid. The Commission advanced the theory that the legislative history of the Act required consideration of the possibility that retention within the holding company system might result in substantial aid in the growth and development of the "additional" system. Cf., 79 CONG. RECORD I4479 (1935). It would not be necessary to show, for compliance with Clause $A$, that an operating system was totally dependent for its existence on aid from the holding company or other properties in the system. In such event the properties in question might not comply with Section 2 (a) (29) (A) as a single integrated system, and the $\mathrm{ABC}$ clauses would therefore have no application to them. I4 S.E.C. 28,62 (1943).

${ }_{223}$ Cities Service Power \& Light Company, I4 S.E.C. 28 (1943). 
able, and customers were continually being lost. No attempt had been made to improve service or to build load, and the Commission was of the opinion that little concern was being manifested over the progressive decline of the properties. The Commission drew the following conclusions:

“. . . These facts illustrate one of the dangers existing when electricity and gas are jointly served in a community. Since Public Service controls both, it is a matter of indifference whether it takes profits from one or the other operation. In fact the higher rate of profit in electric distribution and the necessity of capital outlay to improve the gas properties offer a distinct stimulus to neglect the gas business. This area may perhaps be easily served from natural gas sources. A company which has permitted the condition in Grand Junction to continue and has given no indication of effort to develop its existing manufactured gas resources or to introduce cheaper natural gas and promote its use in competition with electricity certainly cannot claim that substantial economies will be lost by a severance of the properties from its control. ..."28s

An attempt was made by Cities Service to secure the approval of its retention of its Deming, New Mexico, and Tucson, Arizona, electric properties as systems additional to its integrated New Mexico properties. ${ }^{284}$ Evidence was adduced to show that the U. S. Bureau of Reclamation contemplated an interconnection between the Tucson and the Deming properties, and also between the Deming properties and the integrated New Mexico system to the north. These

${ }^{283}$ Id. at p. 66. Accord: The Commonwealth \& Southern Corporation, Release No. 7615 (August I, 1947), and The North American Company, I 8 S.E.C. 6 I I ( I 945$)$.

${ }^{254}$ The integrated system referred to here consisted of the groups designated "C," "D," and "E" on the map of the Cities Service Power \& Light Company system, page 52 , supra. 
proposed interconnections were the principal basis of the claim that substantial economies, within the meaning of Clause $A$, would be lost if the Tucson and Deming properties were severed from the New Mexico group. The Commission noted that the economies which Cities Service claimed would result should the U.S.B.R. construct such lines would depend upon foreign-owned sources of power and foreign-owned transmission lines, and stated that "Clause (A) does not comprehend economies which could be secured without the continued retention of control." ${ }^{285}$ The U.S.B.R. proposals were in no way affected by the ownership of the Cities Service subsidiaries, and the Bureau had stated that it dealt with each of its purchase points as a separate customer, notwithstanding joint ownership of such markets. The conclusion was that the retention of control of Tucson and Deming by the New Mexico system of Cities Service had not been shown relevant to the procurement of the economies which would result from the proposed interconnection, and therefore such benefits could not be considered in passing upon the application of Clause $A$.

With reference to these same properties, evidence was introduced to show that the filing of consolidated tax returns by the various units involved reduced the taxes payable by the Tucson and Deming companies. The estimated taxes in 1942 for the Tucson company, based upon a single return, amounted to $\$ 505,124$; based upon a consolidated return the tax would be $\$ 385,087$, an estimated saving of $\$ 120,037$ or $24 \%$. The estimated saving for Tucson in 1943 was $\$ 126,860$. Further, it was claimed that the independent operation of the Tucson and Deming companies would increase salaries and other operating expenses to compensate for the loss of the services of the system service company. This was claimed to amount

${ }^{355}$ Cities Service Power \& Light Company, I5 S.E.C. 675, 68 I (1944). 
to $\$ 66,000$ for the Tucson company. Other claimed economies brought the total asserted losses of economy and increased costs to $\$ 233,472$ on an annual basis for the Tucson company. The Commission took the position that savings resulting from the filing of consolidated tax returns should not be given definitive weight, making this observation:

“. . . The tax 'savings' resulting from consolidated returns depend upon the present state of the tax lawswhich are subject to frequent change. Should the excess profits taxes be reduced, the theory of computing excess profits be changed, or the taxes eliminated, the major 'savings' would disappear. We do not regard this evidence as demonstrating a continuing condition of advantage relevant to a continuation of control.

"Further, although we do not doubt the business wisdom of attempting to save taxes we cannot permit tax advantages, per se, to distort the administration of the policy of the Act. We are not persuaded that operating properties spread over three states, not shown to be coordinated or otherwise dependent upon the continuation of joint control for efficient, economical operation, may be continued under joint control merely because certain taxes can presently be avoided. The retention of Tucson is not a close legal question which can thus be resolved. Other evidence in the case points strongly to the conclusion that control should be severed. The claim of tax savings does not outweigh that evidence. ${ }^{288}$

The retention of the Deming company as an electric system additional to the New Mexico electric properties was permitted, however. The company was a small one, with net plant of less than $\$ 700,000$ and gross income of less than $\$ 60,000$ for the $12-$ month period ending October 31, 1943 .

${ }^{288}$ Cities Service Power \& Light Company, I5 S.E.C. 675, 682-683 (1 944 ). 


\section{I64 PUBLIC UTILITY HOLDING COMPANIES}

The extent of the economies claimed in this case was not set forth, although it was stated that "considerable" new expenses might be incurred and "considerable" aid resulting from current affiliations might be lost. The Commission observed that "This is the type of company whose retention together with stronger operating properties we believe to be within the meaning of the Act." ${ }^{287}$ The failure of the opinion to give specific figures in this regard makes it difficult, if not impossible, to compare this system with others.

\section{Cities Service Company}

Cities Service Company was the top holding company in a vast system of utility and non-utility enterprises, one of its principal subsidaries being Cities Service Power \& Light Company, discussed above. Although Cities had not made any designation of its choice as to a principal system, it was apparent that its properties known as the "Mid-Continent gas system" constituted such a system. The Mid-Continent gas system consisted of three companies operating in Kansas, Missouri, Oklahoma, and Nebraska. The retainability of various other properties as systems additional to the MidContinent gas system thus became an issue. Cities contended that the Arkansas Louisiana Gas Company ("Arkansas Gas") properties constituted an additional system. It was pointed out that Arkansas Gas and its affiliated oil company, Arkansas Fuel Oil Company, derived great advantages from the Cities Service oil system, such as the right to sell under the Cities Service trade name, and that the loss of those advantages would deprive Arkansas Gas of the "economies" resulting therefrom. This argument was completely rejected by the Commission in view of the fact that it had concluded that under no circumstances might the oil business of Cities Service

${ }^{257}$ Cities Service Power \& Light Company, r 5 S.E.C. 675, 683 (1944). 
be retained with any of its utility systems.

It was also estimated that savings in the amount of $\$ 96$, I $8 \mathrm{I}$ annually, effected through the use of the system service company, would be lost in the event of severance. These claimed savings were I.I $\%$ of the I94I gross operating revenues of Arkansas Gas, 2.7\% of the 194I operating expenses, exclusive of taxes, depreciation, and depletion, and I.5\% of total expenses. These amounts were not considered substantial by the Commission, and in addition the necessity of the disposition of the service company was taken into consideration. Finally, it was contended that the common control of Arkansas Gas with the Mid-Continent gas system would assure Arkansas Gas of access to more of the extensive gas reserves of the latter system. This claim of "substantial economies" was rejected for the reason that Arkansas Gas did not then have access to such reserves and there was insufficient evidence to prove that it would ever have to resort to those reserves. Consequently, the divestment of Arkansas Gas was required because of its failure to meet the requirements of Clause $\mathrm{A}^{288}$

Cities Service also offered evidence to show compliance of the Mid-Continent electric properties and the Rocky Mountain electric properties with Clause A. The Commission made these preliminary comments:

"In considering the standards of Clause (A), it is important first to place those standards in the proper statutory setting when, as here, it is sought to retain together a gas utility system and electric utility systems. Under Clause (A) it must be shown by clear and convincing proof that 'substantial' economies will be lost by severance, and this means 'important' economies. The proof offered must be considered in the light of the facts that

${ }^{288}$ Cities Service Company, I 5 S.E.C. 962 (1 944 ). 
Congress was aware that many holding companies controlled both gas and electric utility companies, and that the retention of additional integrated utility systems is an exception to the general policy of the statute-that holding companies must confine their operations to those of a single integrated public utility system."289

It was claimed by Cities Service that tax savings amounting to $\$ 970,000$ for Public Service of Colorado and $\$ 230,000$ for the Mid-Continent electric system for the year 1942 would result from the filing of consolidated tax returns instead of separate returns. The Commission laid emphasis on three principal fallacies of this argument. First, the estimates of $\operatorname{tax}$ savings were based upon the asumption that the oil properties were to be retained, and the effect of the required severance of these properties had not been explored. Second, such "economies" bore no relation to operational factors, and the extent of the economies depended not upon the type of property involved or the way in which the properties were operated, but upon the accidents of ownership and the state of tax legislation at a given time. Such savings might exist where utility and totally unrelated nonutility properties were combined. And third, there could be no assurance of a continuation of tax savings, as has been pointed out above.

Cities Service also claimed the existence of substantial administrative and general overhead economies resulting from the use of the various system service companies, which would not be available to the Mid-Continent electric properties and the Rocky Mountain electric properties in the event of severance. It was estimated that such separation would cause the Mid-Continent electric group additional costs in the

${ }^{239}$ Cities Service Company, 15 S.E.C. 962, 984 (1944), citing The North American Company v. S.E.C., I 33 F.(2d) 148 (C.C.A., 2d Cir., 1943); Engineers Public Service Company, I2 S.E.C. 4 I (I942); and The Middle West Corporation, 15 S.E.C. 309 (I 944 ). 
amount of $\$ 7 \mathrm{I}, 000$ annually. This was $1.6 \%$ of the I94I electric revenues of such properties. The Commission was of the opinion that the estimated additional costs were considerably overstated; but assuming that they were correct, they did not satisfy the requirements of Clause $A .^{290}$ The same considerations prevailed for the Rocky Mountain electric properties.

\section{The Middle West Corporation}

The Middle West Corporation requested the Commission to find that its electric properties in Wisconsin, Wisconsin Power \& Light Company and Lake Superior District Power Company, could be retained as an additional system to the electric properties of Central Illinois Public Service Company and Kentucky Utilities Company, located in Illinois and Kentucky. ${ }^{291}$ The evidence of "economies" adduced in this connection with reference to Clause A consisted of estimated savings accruing from the joint servicing of these companies and the other northern subsidiaries of Middle West by the system service companies. The service companies handled various administrative functions of the utility business, such as insurance, purchasing, advertising, new business, engineering, finance, accounting, rates, taxes, and legal services. The estimated net savings for the various companies amounted to the following percentages of operating revenue for each company: I \% for Kentucky Utilities; $0.35 \%$ for Central Illinois; $1.3 \%$ for Wisconsin Power; and $1.9 \%$ for Lake Superior District. If the service companies were not allowed to serve the southwestern properties of Middle West, these savings would be smaller by a substantial, although indeterminate, amount. Citing the decisions in the North American

${ }^{290}$ Cities Service Company, I5 S.E.C. 962 (I944).

${ }^{201}$ See map of the Middle West Corporation system, page 65, supra. 
Company case, ${ }^{292}$ and the Engineers Public Service Company case, ${ }^{293}$ the Commission held that it could not find that the severance of the electric or gas utility businesses of Wisconsin Power and Lake Superior District from joint control together with any retainable system in the northern sector of Middle West would cause the loss of substantial economies. ${ }^{294}$

Oklahoma Power \& Water Company, a Middle West subsidiary in northern Oklahoma, jointly carried on electric and gas operations. Personnel used in the operation of the gas department was, to some extent, the same as that used in the electric operations. General office facilities were shared, billing and meter reading were jointly done, and the same garage facilities were used by both. It was estimated that the elimination of both the gas and water departments of the company would result in increased expenses to the electric department of $\$ 54,578$, or $5.1 \%$ of the gross electric revenues of the company for $1939 .{ }^{295}$ The Commission pointed out that it was impossible to determine what portion of this amount would be due to the elimination of the gas properties alone. Furthermore, the evidence was insufficient to show how many integrated gas properties were involved. Consequently, it was held that the requirements of Clause $A$ were not met in this instance. $^{296}$

${ }^{202}$ The North American Company, II S.E.C. 194 (1942); The North American Company v. S.E.C., 133 F.(2d) 148 (C.C.A., 2d Cir., 1943).

${ }^{298}$ Engineers Public Service Co. v. Securities Exchange Commission, 138 F.(2d) 936 C.A.,D.C., 1943 ).

${ }^{294}$ The Middle West Corporation, 15 S.E.C. 309 (1944).

${ }^{205}$ Note that the approach here is the claim of savings to the retainable electric system, and not to the gas system. In Engineers Public Service Company v. Securities Exchange Commission, I 38 F.(2d) 936 (C.A.,D.C., I943), the court indicated its disapproval of such an approach to the problem, although it is not mentioned in this case.

${ }^{296}$ The Middle West Corporation, I5 S.E.C. 309 ( 1944 ). 


\section{Philadelphia Company}

Philadelphia Company was a sub-holding company in the Standard Gas \& Electric Company holding company system, which in turn was a sub-holding company in the Standard Power \& Light Company holding company system. Philadelphia Company was engaged, through its subsidiary companies, in supplying electric, gas, transportation, and other services in the City of Pittsburgh and its surrounding area. The date of its organization was $187 \mathrm{I}$, and its operations commenced in 1884, thereby making it one of the oldest utilities in the nation. It was originally engaged in the natural gas business, but in I 899, it acquired electric and street railway interests, and after that date it operated as a holding company. In I94I the Commission held that the electric utility system of Philadelphia Company was integrated. ${ }^{297}$ Seven years later the gas utility system was found to be integrated. ${ }^{298}$ Philadelphia Company elected to retain its electric properties as its single or principal system, thereby raising the question of the retainability of the gas utilities as an additional system.

Philadelphia Company introduced evidence to show that increases in annual operating expenses would result upon severance of common control. The claimed increases are shown in the following table:

\begin{tabular}{|c|c|c|c|c|c|}
\hline & $\begin{array}{l}\text { Electric } \\
\text { Group }\end{array}$ & $\begin{array}{c}\text { Gas } \\
\text { Group }\end{array}$ & $\begin{array}{l}\text { Transporta- } \\
\text { tion Group }\end{array}$ & & Total \\
\hline Payroll & $\$ 377,526$ & $\$ 367,05^{8}$ & $\$ 84,542$ & $\$$ & 829,126 \\
\hline $\begin{array}{l}\text { Social Security, annuity, in } \\
\text { surance \& hospitalization }\end{array}$ & 22,527 & 21,816 & 5,255 & & 49,598 \\
\hline Space Rental & 61,312 & $40,35^{8}$ & 4,919 & & 106,589 \\
\hline Other Expenses & 63,823 & $7^{1}, 096$ & 3,377 & & 138,296 \\
\hline Total & $\$ 525,188$ & $\$ 500,328$ & $\$ 98,093$ & & 123,609 \\
\hline
\end{tabular}

The Commission conceded that these alleged amounts of increased expenses were substantial in the absolute sense, but

${ }^{207}$ Standard Power \& Light Corporation, 9 S.E.C. 862 (1941).
Philadelphia Company, Release No. 8242 (June I, 1948). 


\section{0 PUBLIC UTILITY HOLDING COMPANIES}

was of the opinion that, in the context of Clause $A$, the "substantiality" of asserted losses of economies could not be measured in absolute terms, but rather should be evaluated in relation to total revenues, expenses, and income. ${ }^{299}$ This approach had been adopted by the Commision in earlier decisions, notably in connection with the Virginia Electric \& Power Company gas system and the Gulf States Utility Company gas system of Engineers Public Service Company, ${ }^{300}$ and the gas system of St. Louis County Gas Company in The North American Company system. ${ }^{301}$ In each of these latter cases it had been held that the claimed losses of economies were not adequate to meet the requirements of Clause $A^{3.20}$ An interesting comparison of Philadelphia Company with these companies is shown by the table on the following page.

This table shows that in each instance Philadelphia's claimed increases in expenses were considerably less than those held not to be substantial in the Engineers and North American cases. The conclusion naturally followed that, even on the basis of Philadelphia's own figures, the Commission could not find that the claimed increased expenses would represent a loss of substantial economies within the meaning of Clause A. ${ }^{303}$

In addition, the Commission found that the claims of Philadelphia in this regard were fallacious. The company's proof had consisted principally of certain studies made by Paul B. Coffman, president of Standard Research Consultants, Inc., and an assistant professor in the Harvard Graduate School of Business Administration. The figures given above were

${ }^{200}$ Philadelphia Company, Release No. 8242 (June 1, 1948), mimeo. p. I6.

${ }^{800}$ Engineers Public Service Company, I 2 S.E.C. 4 I (1942).

${ }^{801}$ The North American Company, 18 S.E.C. 6 I I (1945).

${ }^{802}$ This table appears in Philadelphia Company, Release No. 8242 (June 1 , 1948), mimeo. p. r 9. Also, see the same table as revised to include General Public Utilities Corporation, infra, p. 186.

${ }^{303}$ Philadelphia Company, Release No. 8242 (June I, 1948). 


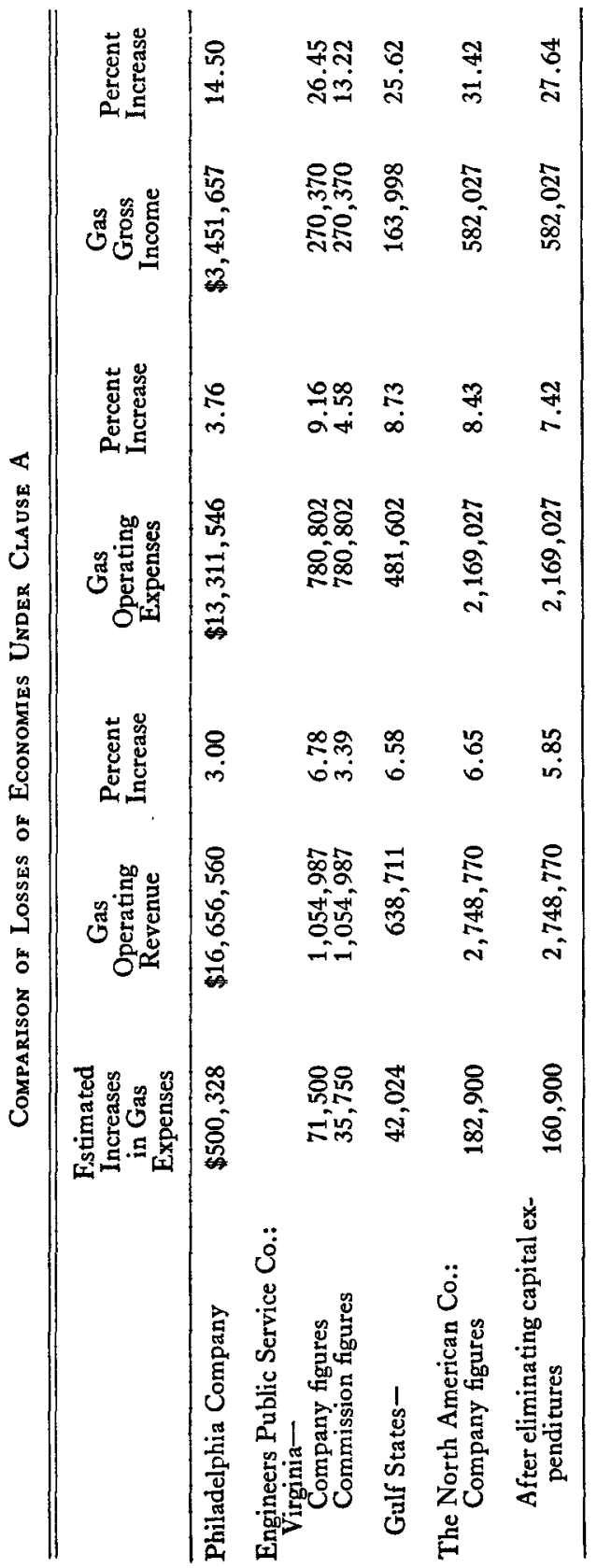


taken from his presentation. In a scathing denunciation, the Commission held that Coffman lacked the necessary qualifications for a study of this type, that his methods were inadequate, and that he was generally unfamiliar with the work, even after its completion by his staff. ${ }^{304}$ In addition, the Commission objected to his failure to study the effect of segregation upon the overall operations of the system, to his assumption that the existing administrative organization should be continued, to his acceptance of the company's method of allocating general administrative expense among the companies of the system without testing the reasonableness or accuracy of such allocations, to his failure to make an independent examination of rental space requirements and costs after segregation, and to his assumption that upon segregation Philadelphia Company would continue as a holding company over the electric group and the real estate company of the system. ${ }^{305}$

Philadelphia Company tried to reinforce Coffman's conclusions by the testimony of two other witnesses, Jay Samuel Hartt, a utilities analyst, and E. C. Stone, a retired officer of the company. Neither of these witnesses made any separate independent investigation, but merely examined Coffman's studies to determine the accuracy of his conclusions. They expressed the opinion that the methods of procedure employed by Coffman in his studies were sound and produced a reasonably assured result. The Commision was of the opinion that the basic defects in Coffman's studies were carried over into the conclusions reached by Hartt and Stone, and consequently rejected their testimony also as proof of the loss of substantial economies on segregation. It was consequently impossible for

${ }^{304} I d$. at mimeo. pp. 27-28.

${ }^{805}$ The opinion of the Commission is very detailed and sarcastic at this point. It is an interesting illustration of the difficulties involved in complying with Clause A. Philadelphia Company, Release No. 8242 (June 1, 1948), mimeo pp. 28-39. 
the Commission to find that the record would only support a part of the claimed increase in expenses, as was done in the Engineers' case, ${ }^{306}$ since here the basic defects in the evidence offered on increased expenses made it impossible to attempt to estimate just what the proper amount would be, if any.

Philadelphia included another item in its claim of loss of substantial economies, the savings resulting from the use of a consolidated tax return by the parent company and its subsidiaries. The Commission rejected this contention once again, remarking that "we cannot permit the incidence of tax savings to disrupt the basic policy of the Act that holding companies generally be limited to a single integrated system."

After the Commission had entered its adverse decision against Philadelphia Company, the latter filed a petition for rehearing and for leave to adduce additional evidence. The Company claimed that the Commission had for the first time presented an extensive series of legal tests and requirements relative to the proof of compliance with the standards of Clause $A$, and that the company had been prejudiced by reason of its lack of advance notice or knowledge thereof. These assertions were found to be without merit by the Commission. ${ }^{308}$ As we have seen, the legal tests and requirements set forth by the Commission in this case were merely the application of established principles laid down in earlier decisions. The Commission was of the opinion that no amount of supplementation of Coffman's testimony would suffice to alter its conclusions. It was noted that no contention was made that any evidence desired to be adduced at this time was unavailable at the time of the hearings or that in the exercise of due diligence it could not have been presented then. The petitioners' claims were interpreted merely as an expression

\footnotetext{
${ }^{800}$ Engineers Public Service Company, I 2 S.E.C. 41, 60 (1942).

${ }^{807}$ Philadelphia Company, Release No. 8242 (June I, 1948), mimeo. p. 41.

${ }^{308}$ Philadelphia Company, Release No. 8320 (June 30, 1948).
} 
of their disagreement with the conclusion reached in the original case.

The decision of the Commission in the Philadelphia Company case was affirmed upon appeal to the U. S. Court of Appeals for the District of Columbia. ${ }^{300}$ The principal grounds for the affirmance on the Clause $A$ issue were the recognized rules that such problems were peculiarly fitted for decision by an administrative agency staffed by experts, and that the determinations of such an administrative body should not be disturbed upon appeal unless they appeared to be unreasonable. The court also adopted the cintangible benefits" theory so often employed by the Commission. It was noted that in spite of possible increased costs resulting from segregation, certain compensating advantages should accrue from the concentration of the energies of all personnel on the problems of each of the single systems to which they would be assigned and to which they would owe undivided allegiance. The companies argued that these so-called advantages were based upon unsupported conjecture and speculation. The court held that the Commission was entitled to draw inferences from facts not of record and that the "Commission did not err in assuming (I) that men can give more time, energy, and allegiance to an employer if they give none to his competitor and (2) that, within normal limits, more is better than less." ${ }^{310}$ The court further confirmed the Commission's opinion that economies were not "substantial," within the meaning of Clause A, unless their loss would cause a serious economic impairment of the system such as to render it incapable of independent economical operation. In any

${ }^{309}$ Philadelphia Company v. S.E.C., 177 F.(2d) 720 (C.A.,D.C., 1949).

${ }^{310}$ Id. at pages 724-725. The court noted that perhaps the Commission had set up an erroneously high standard of proof under Clause $A$ in requiring "clear and convincing evidence," but that no prejudice resulted to the companies involved since the Commission did not think their case was proved by any standard, however low. 
event, "substantial" economies must be "important" economies, and this requirement was not met in this case. ${ }^{311}$

\section{Eastern Utilities Associates}

The Commission found that Eastern Utilities Associates and its subsidiaries included an integrated electric utility system operating in the states of Rhode Island and Massachusetts, covering an area of approximately 500 square miles, with electric operating revenues for the year 1948 amounting to $\$ 19,142,000$, and that the manufactured gas properties of one of the subsidiaries, serving an area of approximately roo square miles in Rhode Island, with gross operating revenues for 1948 of $\$ 2,234,002$, constituted an integrated gas distribution system, within the meaning of the Act. ${ }^{312}$ The electric utility operations obviously constituted the principal system of the company, but EUA sought to retain the gas system as an additional system. It was conceded by the Commission that the requirements of Clauses $\mathrm{B}$ and $\mathrm{C}$ were met, and EUA introduced considerable evidence to demonstrate the retainability of the gas system under Clause A. In the first place it was contended that the separation of the electric and gas businesses would result in the loss of substantial economies because of certain construction expenditures which would be required if the properties were separated. In discussing the various items presented by EUA, the Commission first pointed out that there was considerable question as to the weight to be given to the necessity for capital expenditures as compared with increases in operating expenses under Clause $\mathrm{A}^{313}$

The major item of construction alleged to be required upon separation was a new steam plant, estimated to cost

${ }^{311}$ The court was merely affirming its position in the case of Engineers Public Service Company v. S.E.C. 138 F.(2d) 936 (C.A.,D.C., 1943 ).

${ }^{212}$ Eastern Utilities Associates, Release No. 9784 (April 4, 1950).

${ }^{313}$ Ibid. Cf., The North American Company, 18 S.E.C. 611 (1945). 


\section{I76 PUBLIC UTILITY HOLDING COMPANIES}

$\$ 600,000$. The Commission was of the opinion (a) that after separation the electric company could easily supply excess steam to the independent gas company on a contract basis; and (b) that a substantial part of the estimated cost of the new steam plant was attributable to an increased capacity to take care of future needs and therefore would not be a loss resulting from the separation of the gas and electric system. EUA also contended that separation would require the construction of a new wharf and the purchase of new coal handling equipment, estimated to cost $\$$ I 75,000 . The Commission found that neither the wharf nor the coal handling equipment had been used by the electric department to any substantial degree since 1923 and could see no reason why these facilities should not be divested with the gas properties. It was recognized that some small expenditures might be required for new furniture and similar items upon separation, but the Commission was of the opinion that the estimates submitted in this regard were excessive but in any event not large enough to meet the test of Clause A.

EUA also claimed that substantial increases in operating expenses would result upon separation of the gas and electric systems. The principal items involved were the increases in payroll expenses required by the addition to the full time gas employees of Blackstone Valley Gas \& Electric Company, the EUA subsidiary operating the gas system, of the number of employees estimated to be necessary to perform the services currently rendered by employees serving both the gas and electric departments. The staff of the Public Utilities Division prepared a statistical comparison of the current and projected expenses of Blackstone with those of all manufactured gas companies in Massachusetts which were solely gas utilities and which were comparable in size with Blackstone's gas department. Condensed, these figures showed the following: 
No. of

Customers

10 independent gas companies,

average

Blackstone

Blackstone adjusted
37,231

47,202

47,202
Commercial, New Business and General Expense, per Customer

The adjusted figures for Blackstone included all of the increased operating expenses estimated by EUA except for interest, depreciation, and taxes on the projected new facilities. The adjusted estimates for Blackstone upon separation were $30 \%$ higher than the expenses of the highest comparable company, and over $50 \%$ higher than the average. The Commission recognized that the expenses of a given gas company did not of necessity have to correspond with those of any other, but was of the opinion that the burden was upon EUA in such a situation to adduce proof of unusual circumstances to justify this variance in expenses, commenting that no such proof had been submitted. The conclusion of the Commission was that 'the record does not support the Respondents' (EUA's) contention that the combined operation of the electric and gas properties has resulted and will result in such efficiency and savings to counterbalance the economy of operation generally resulting from the normal and true competition existing between these two basically competing sources of energy. In fact, the record suggests the opposite conclusion." ${ }^{\text {14 }}$ Consequently, retention of the gas system was denied under Clause A.

\section{Lone Star Gas Corporation}

The large group of natural gas properties owned by Lone Star Gas Corporation and located in northern and north central Texas and a small adjoining portion of Oklahoma was held to constitute a single integrated gas utility system, but the outlying gas properties at El Paso and Galveston were

\footnotetext{
${ }^{31+}$ Eastern Utilities Associates, Release No. 9784 (April 4, 1950), mimeo. p. 27.
} 


\section{I78 PUBLIC UTILITY HOLDING COMPANIES}

excluded from the integrated area. Lone Star contended, however, that these latter properties were retainable as additional systems. With reference to substantial economies, Lone Star estimated that it would cost independent operators an additional $\$ 18,733$ for the E1 Paso properties and \$I 7,957 for the Galveston properties per year in the event of separation, being salaries of management and supervisory personnel needed to replace the holding company management and control. These figures amounted to $2.2 \%$ and $4.1 \%$, respectively, of total r94I operating expenses of $\$ 844$, IO 8 for the El Paso division and $\$ 432,867$ for the Galveston division. The Public Utilities Division submitted studies which indicated that there would be no increase in such charges in the event of separation, and the City of El Paso introduced evidence tending to show that it would cost less to operate the El Paso properties separately than as a part of the Lone Star system. Relying upon the rule laid down in The North American Company case, ${ }^{315}$ to the effect that "substantial economies" in Clause A meant economies of an important nature rather than purely nominal or minor economies, the Commission held that the requirements of Clause A were not met by the El Paso and Galveston properties. ${ }^{316}$ This conclusion would seem to be justified even if the estimates submitted by Lone Star were deemed to be accurate.

\section{Columbia Gas E Electric Corporation}

The gas utility operations of the Charleston, Pittsburgh, and Columbus properties of Columbia Gas \& Electric Corporation were each held to constitute a single integrated gas utility system. ${ }^{317}$ The parent company sought to retain these three systems as one principal system and two additional

\footnotetext{
${ }^{315}$ The North American Company, ir S.E.C. 194 (1942).

${ }^{316}$ Lone Star Gas Corporation, I2 S.E.C. 286 (1942).

${ }^{a 17}$ Columbia Gas \& Electric Corporation, I7 S.E.C. 494 (1944).
} 
systems, the principal system not being specified. The utilities in the Charleston and Pittsburgh groups were operated as coordinated systems and derived their natural gas from common sources of supply. These facilities were connected with those of the Columbus group, and there existed a close operating relationship among the three systems. Drilling, production, storage, and transmission operations were coordinated with the marketing requirements of the three systems in order to obtain a maximum use and conservation of the available gas supply, particularly significant because of the depletion of natural gas in the Appalachian area. Without discussion of any dollar amount of estimated economies, the Commission held that these three systems were jointly retainable. ${ }^{318}$ However, retention of the Cincinnati and Dayton groups of properties, both electric and gas, was denied under the $A B C$ Clauses for lack of evidence. The Commission was of the opinion that no showing of compliance could be made because of the divergent character of the respective properties, the lack of operating relationships between the properties, and the financial independence of these two systems.

\section{Peoples Light E' Power Company}

The principal subsidiary of Peoples Light \& Power Company was Texas Public Service Company, which was mainly a natural gas utility serving the cities of Austin, Galveston, and Port Arthur, Texas. ${ }^{319}$ Texas Public Service

sis Ibid.

${ }^{310}$ The acquisition of the Galveston properties by Texas Public Service Company was authorized under Section $x o(c)$ of the Act in Peoples Light \& Power Company, ${ }_{5}$ S.E.C. I 20 (1 943), and the acquisition of the Port Arthur properties was approved in Peoples Light \& Power Company, r4 S.E.C. 555 (I 943 ). The basis of these decisions was not that the three groups of properties in Austin, Galveston, and Port Arthur constituted an integrated gas utility system, but that "certain operating economies" would result and that upon the proposed dissolution of Peoples Light \& Power Company, the Texas Public Service Company would be a local operating company confined to the State of Texas and consequently not subject to the jurisdiction of the Commission. This is a patent evasion of the issue by the Commission. 
Company also operated an electric utility system at the town of La Grange, Texas, located between Austin and Galveston, and sought to retain it as an additional system. The company contended that it would cost considerably more to operate the La Grange properties independently than under the ownership of the Company, although it had made no cost study of this matter. The president of Peoples Light \& Power Company testified that independent operation of the La Grange properties would result in an increase in expenses of between $\$ 6,000$ and $\$ 8,000$ per year, consisting of $\$ 2,500$ for an independent manager, $\$ 2,000$ for an additional employee to handle billing done mechanically by the main office of Texas Public Service Company, and \$ I,000 for attorney's fees, with the balance unexplained.

Practically all the power requirements of La Grange were purchased from a non-affiliated source and only a small generating unit was maintained for stand-by purposes. The feeling of the Commission in this connection was that the La Grange properties could well be operated in conjunction with this non-affiliated source upon separation, thereby securing the same benefits claimed by Texas Public Service Company. Also, the lack of generating problems made the problems of management much less extensive than if substantial production and supply problems were also involved. Further, the record showed that the La Grange electric properties were separately staffed and there was no evidence that the current local manager could not continue to provide the necessary managerial services upon severance. Finally, the Commission doubted the necessity of the increased expense for the billing employee, since such service might well be secured from an outside source or even from the main office of the Peoples' system at Austin. The conclusion of the Commission relative to the retention of the La Grange Electric properties as an additional system was stated as follows: 
"It is clear that the statutory requirement of 'substantial economies,' which is contained in an exception to the general policy that a holding company is to be limited in its operation to a single integrated public utility system, must be strictly construed against those claiming its benefits. [Citing Engineers Public Service Company, I 2 S.E.C. 4 I (I 942)] Having the policy of the Act in mind, we have carefully considered the evidence and are satisfied that it will not sustain a finding that 'substantial economies' within the meaning of Clause (A) would be lost by the severance of the La Grange electric properties from the control of Peoples. This conclusion renders unnecessary any findings under Clause (C) and requiries that we order divestiture of the La Grange electric properties."320

\section{American Gas E Electric Company}

The three divisions of the American Gas \& Electric Company system have been described above. ${ }^{321}$ It was contended by American Gas \& Electric Company that its northeast Pennsylvania and south Jersey systems were retainable as additional systems to the central system. In connection with Clause A, it was alleged that joint operation of these three systems resulted in administrative, accounting, financial, engineering, purchasing, tax, and other economies. It was claimed that additional personnel would be required for each of these systems upon separation, in the form of a president, vice-president, secretary, treasurer, controller, chief auditor, counsel, statistician, purchasing agent, two engineers, and additional clerical, stenographic, and other office employees.

The Commission felt that the estimated additional number of personnel required was excessive; that the asserted expenses relating to such personnel were too high; and that

\footnotetext{
${ }^{320}$ Peoples Light \& Power Company, 20 S.E.C. 357, 381 (1 945).

${ }^{321}$ See map at page 78 , supra.
} 


\section{I82 PUBLIC UTILITY HOLDING COMPANIES}

the company overlooked the offsetting cost of maintaining the holding company over these two subsidiaries, which the Commission considered to be substantial, although difficult to isolate. And finally, the Commission believed that the credit and investment standings of the Pennsylvania and New Jersey properties were such that there would be no loss of economies in the raising of capital if they should be severed from the control of American Gas \& Electric Company. Accordingly, the Commission held that the requirements of Clause A were not met in this situation. ${ }^{322}$

\section{General Public Utilities Corporation}

General Public Utilities Corporation was organized in 1944 as the successor to Associated Gas \& Electric Company and heir to the Hopson utility empire. The affairs of Associated Gas \& Electric Company and its subsidiaries had been administered by trustees since I940, when petitions for reorganization under Chapter $\mathrm{X}$ of the Bankruptcy Act were filed. The trustees worked closely with the Commission and a number of Commission employees were engaged by the trustees to assist in the reorganization of the company and its many subsidiaries. After I940, therefore, the company demonstrated a spirit of cooperation with the Commission quite generally lacking in the other public utility holding companies. This fact must be kept in mind when studying the Associated Gas \& Electric Company and General Public Utilities Corporation cases.

New York State Electric \& Gas Corporation, a subsidiary of General Public Utilities Corporation, was engaged in the electric and gas utility businesses in the eastern, central, and western parts of the state of New York, an area of approxi-

\footnotetext{
I 945$)$.

${ }^{322}$ American Gas \& Electric Company, Release No. 6333 (December 26,
} 
mately 16,700 square miles. For the calendar year 1948, its electric operating revenues totaled $\$ 38,167,264$, and its gas operating revenues were $\$ 6,300, \mathrm{I} 68$. Before the formation of General Public Utilities Corporation, the trustees of $A G \& E$ and its subsidiaries had indicated that they believed the empire could be divided into four separate integrated holding company systems. ${ }^{323}$ One of these systems was located in New York and northern Pennsylvania, and included New York State Electric \& Gas Corporation, Rochester Gas $\&$ Electric Corporation, and Northern Pennsylvania Power Company ("North Penn") as its principal components. At a later date, however, General Public Utilities decided to divest itself of New York State separately from its neighboring companies. ${ }^{324}$ Inasmuch as New York State and North Penn had been under common control since 1926, and since the former had been supplying the power requirements of the latter since that time, the Commission found itself in the novel position of questioning a separation of utility companies. The Commission was not concerned with the separation of New York State from Rochester, since both of these companies were of sufficient size and scope of operations to be in a position to operate economically and efficiently as independent entities and there were no significant operating relationships between the two. ${ }^{325}$

In addition to furnishing power to North Penn, New York State rendered other services to that company, including meter supervision, billing of customers' accounts and maintenance and repair of transmission lines. North Penn also employed, on a part-time basis, the power sales promotion engineer and

${ }^{323}$ Associated Gas \& Electric Company, I5 S.E.C. 743 (I944).

${ }^{324}$ The operations of New York State Electric \& Gas Corporation were conducted in southern and northeastern New York.

${ }^{325}$ New York State Electric \& Gas Corporation, Release No. 8924 (March I I, I 949). 
the safety director of New York State. The Commission felt that New York State and North Penn, under these conditions, could well be deemed an integrated system under the provisions of Section II (b) (I), and was reluctant to permit their separation from each other. However, the Commission concluded that it would not overrule the judgment of the management in this regard. ${ }^{326}$ Testimony had been adduced to show that North Penn could be converted into an independent company and that a continuing supply of power would be available to it, although it could hardly be called "clear and convincing." The opinion expressly reserved the question as to whether North Penn might be retained with the other properties of General Public Utilities Corporation in Pennsylvania and New Jersey. This decision appears to indicate that Clause A cannot be applied conversely, i.e., that if an additional system cannot be operated as an independent system without the loss of substantial economies, it may still be segregated if its companion system so desires. This interpretation must be considered in the light of the circumstances surrounding the integration problems of General Public Utilities Corporation, however.

In a subsequent proceeding the fate of North Penn was determined. GPU sought to retain North Penn in addition to its integrated Penn-Jersey System. In order to prove that the loss of economies to North Penn would be substantial if it were separated from the principal system, GPU presented a severance study. The results of this study are shown on the following page in comparison with similar data for other systems. ${ }^{32 z}$ This table indicates that claims of larger losses in

${ }^{320}$ Ibid.

${ }^{327}$ This table is set forth in General Public Utilities Corporation, Release No. I0982 (December 28, 1951), at mimeo. p. 26. The difference between the figures in this table and those in the table set forth at page I $7 \mathrm{I}$, supra, result from the fact that federal income taxes were deleted from the figures in this table. 
prior cases had been rejected as insufficient to satisfy the requirements of Clause $A$, and consequently GPU's claims were also rejected.

GPU also asserted that North Penn would incur increased costs in obtaining equity capital upon severance. The Commission discarded this argument for several reasons. First, it felt that within a relatively short time the common stock of North Penn, if independent, would become sufficiently seasoned. Secondly, the Commission did not agree that the I $5 \%$ differential asserted by GPU was supported by the evidence. And thirdly, it appeared that during the preceding Io years the common stock financing of North Penn had only averaged $\$ 73,000$ per year, and the Commission noted that I $5 \%$ of this amount, $\$ 10,950$, was not substantial.

Further, the Commission concluded that North Penn was not incapable of independent economic operation. As of December $3 \mathrm{I}$, I950, its fixed property amounted to $\$ 9,67 \mathrm{I}, 000$ and for the calendar year 1950 its gross operating revenues were $\$ 4,499,000$. Its gross income was $\$ 674,000$ and its net income was $\$ 54 \mathrm{I}, 000$. It was also observed that in the proceedings involving New York State Electric \& Gas Corporation the question of the ability of North Penn to operate independently was considered at length, and it was at the insistence of GPU that the two properties were separated from each other, in spite of their long history of joint operation. It was therefore held that North Penn did not satisfy the requirements of Clause $\mathrm{A}$ as a system additional to PennJersey. ${ }^{328}$

GPU also sought to retain the integrated gas utility system of Jersey Central Power \& Light Company ("Jersey Central"), along with the integrated electric utility system of Penn-Jersey. A severance study had also been made in connec1951).

${ }^{328}$ General Public Utilities Corporation, Release No. 10982 (December 28, 


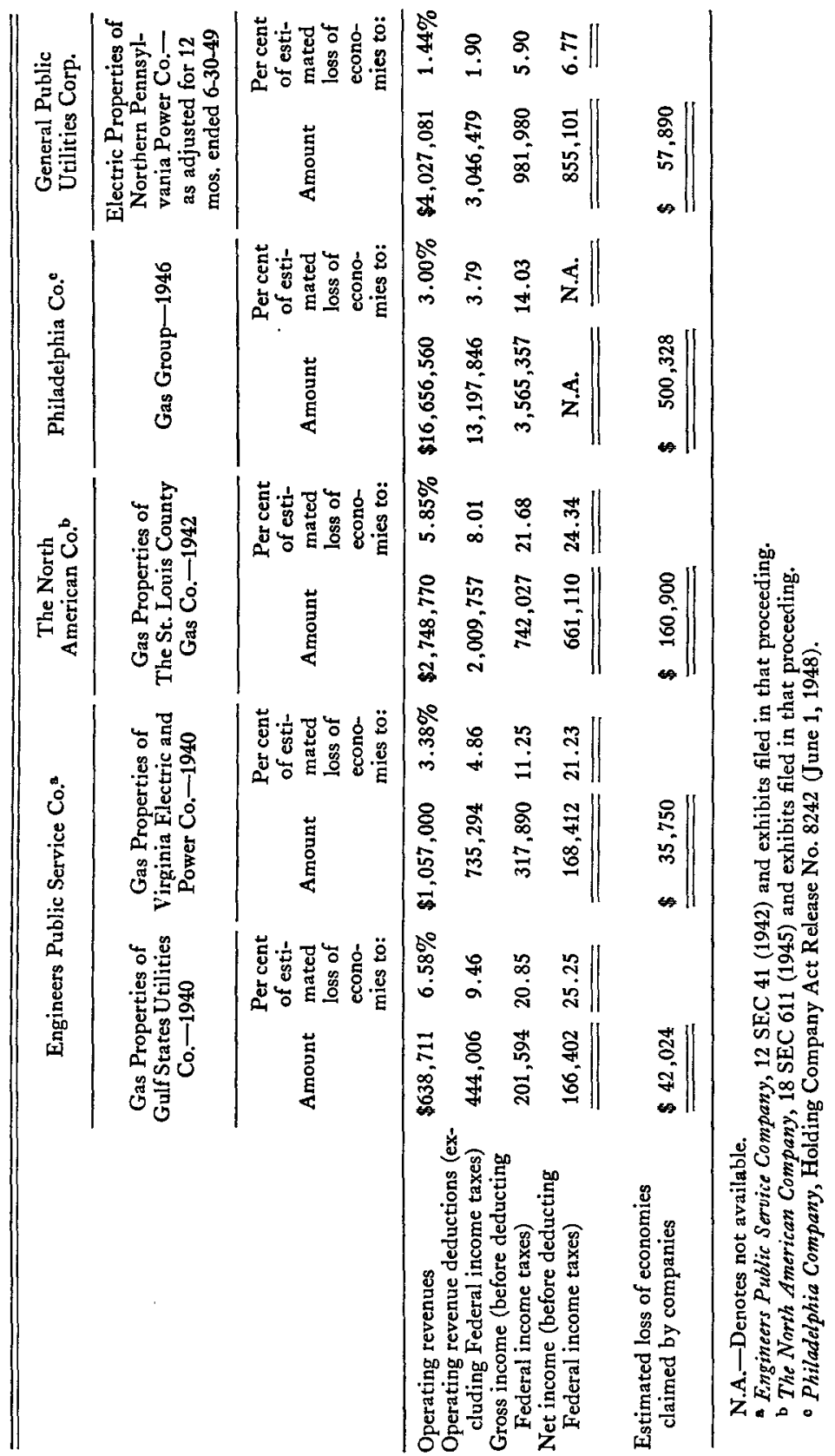


tion with these properties, but it, too, was rejected by the Commission as insufficient to prove compliance with Clause A. The study contemplated the distribution of manufactured gas by Jersey Central, whereas the system was being converted to natural gas which, it was contemplated, would substantially improve its earning capacity. Further, the estimated losses of economies shown by the study were comparatively less than those rejected in previous cases, provided certain adjustments were made to the income figures of the gas system so as to reflect a fair return.

The Commission held that the requirements of Clause A had not been met here. ${ }^{329}$ It refused to consider estimates indicating a loss of economies to the separated electric system as compared with the electric department of the combination company, on the ground that the losses in economies which could be considered under Clause A were limited to those directly related to the additional system sought to be retained and not to the principal system. ${ }^{330}$

\section{Summary of the Requirements of Clause $A$}

It is obvious from the foregoing that the requirements of Clause A have been rigorously enforced by the Commission, and only in rare instances has compliance been decreed. The rules relating to the retention of additional systems have been viewed as an exception to a clearly expressed general policy, and as such have been strictly construed. The "loss of substantial economies" set forth in Clause A must be proved by "clear and convincing evidence," which appears to require more than proof by a preponderance of the evidence. Although this added burden of proof is probably not justifiable, it has been upheld by the courts.

The standard of "substantial economies" is related to the

${ }^{329}$ I bid.

${ }^{330}$ Citing Philadelphia Company, Release No. 8242 (June I, I 948). 
economies which redound to the benefit of the integrated systems involved rather than to the holding company standing over such systems, so that the gain or loss to the holding company upon separation is not to be taken into consideration. There is always some cost required to maintain the top holding company, and upon its elimination there will be some concomitant increase in cost to the operating properties. The Commission feels that such cost must always be deducted from any estimate of loss of economies upon separation.

The basic rule laid down by the Commission for the interpretation of Clause A is that the word "substantial" means "important," and not merely something more than nominal. This principle is also founded upon the consideration that Congress intended to eliminate all but the most closely knit systems. The corollary of this is that economies are not substantial, within the meaning of Clause $A$, unless their loss would cause a serious economic impairment of the system involved, so as to render it incapable of independent economical operation. This interpretation of Clause A virtually removes all possibility of compliance therewith and seems to be unduly strict in view of the fact that Congress apparently recognized that there were some exceptions worthy of recognition.

The method of proof in the cases concerned with compliance with Clause $A$ has generally been the production of evidence showing increased expenses resulting to the systems upon separation. The Commission has noted that the law makes no reference to increased expenses, but speaks of loss of economies, and has never conceded that the two words are equivalent for the purposes of the Act. Perhaps the proper view is to consider a substantial saving in operational expenses as one element of substantial economies. The particular expenses claimed by the various systems to be increased by a separation of properties have been quite extensive. They 
have included increases in the following departments and functions: accounting, auditing, budgets, taxes, meter reading, billing, collection, administrative, executive, clerical, stenographic, sales promotion, advertising, purchasing, financing, insurance, legal, rates, engineering, safety, maintenance, and repair. The Commission normally compares the total amount of estimated increase in expenses with the operating revenue, operating expense, and gross income of the system involved for the most recent year available to determine its substantiality. The highest percentages in each instance resulting from these comparisons have been $6.58 \%, 9.46 \%$, and $20.85 \%$, respectively, all have been held to be inadequate for compliance with Clause A. Also, the Commission consistently discounts these estimates as being exaggerated, both with regard to the number of additional personnel required and the cost of procuring such personnel. Although it is advisable to consider all three items, revenue, expense, and gross income, the second one is perhaps the best basis for testing the claimed expenses. Certainly it would seem that increased expenses amounting to Io\% of operating expenses should be deemed substantial, and in appropriate cases something less than that amount might suffice.

Claims of increased expenses upon separation, other than for additional personnel, have been based upon the joint use of facilities by the systems to be divided, usually a gas and an electric system serving the same general area. These facilities have included automotive equipment, meter shops, central office, steam plant, and coal handling equipment. None of such claims have been held to be substantial. Numerous companies have presented evidence of large savings resulting from the filing of consolidated income tax returns by the systems involved. The Commission refused to take this evidence into consideration for two basic reasons. First, tax savings have no relation to the operational factors which the 
Act contemplates, and such savings depend upon the accidents of ownership and the state of tax legislation at a given time, not upon the type of properties involved or the way in which they are operated. And secondly, the tax laws are subject to frequent change and the excess profits tax which then prevailed might be eliminated. The wisdom of this latter proposition needs no elaboration.

A majority of the cases under Clause A have been concerned with the possible retention of an integrated gas utility system in addition to a principal electric utility system. In this situation the Commission has adopted its theory of intangible benefits. This theory is that the separation of the electric and gas properties will result in certain benefits to both, particularly the gas system, which, although intangible and incapable of accurate measurement, must be taken into consideration as a factor offsetting claimed increases of expenses or other losses of economies upon separation. It was the observation of the Commission that in numerous instances the gas business of a combined electric and gas company, being the one which produced the smaller amount of revenue and profits, was suppressed or neglected by the company, to its substantial detriment. The two lines of business are competitive to a large extent and the natural tendency of joint control is to favor the most profitable function. In an effort to measure this intangible factor the staff of the Public Utilities Division compiled figures comparing the operations of combination gas companies and independent gas companies. The comparison was favorable to the independent operations, although the margin of difference was small. However, there has been considerable evidence to prove the abuse of gas properties in this situation, and the Commission is justified in assuming in a proper case that separation will result beneficially to the gas system. The courts have sustained the intangible benefits theory and it now appears to be a fixed rule of interpretation under Clause $\mathrm{A}$. 
Only in very exceptional circumstances has the Commission granted its approval under Clause $A$ of the retention of an additional system. In The North American Company, Engineers Public Service Company, and Cities Service Power \& Light Company cases, the Commission permitted retention of several extremely small orphan systems which had been held to be individually integrated on somewhat tenuous grounds. In the Columbia Gas \& Electric Corporation case, three substantial gas properties were held to constitute a principal system and two retainable additional systems under Clause $A$, but the proof indicated that the three properties more closely resembled a single integrated gas utility system. The retention of a gas utility system in addition to an electric utility system has never been permitted to date, mainly by virtue of the strict interpretation of Clause A by the Commission.

\section{B. Geographical Proximity}

The second of the cumulative requirements imposed by the Act for the retention of utility systems in addition to the principal system provides that all of such additional systems must be located in one State, or in adjoining States, or in a contiguous foreign country. ${ }^{331}$ This brief requirement of the Act has probably been more disastrous to the sprawling utility empires than any other provision of the law. It was early referred to as "Big B," and it has amply justified the title. At the outset the Commission seized upon the requirements of this provision to pare large segments of existing utility combinations before the more difficult and abstruse standards of the Act were applied. Although at first glance the meaning of Clause B is clear, there were complications which had to be resolved by the Commission. The Commission acted quickly

${ }^{331}$ Section $1 \mathrm{I}(\mathrm{b})(\mathrm{I})(\mathrm{B})$, referred to herein as "Clause B." 
in this regard, and, although it might be accused of a bit of administrative legislation, the Commission enunciated an interpretation which was sustained by the courts. This interpretation has been consistently followed throughout the history of the Act and has been long considered as part and parcel of the law itself. Consequently, the study of Clause B must begin with such interpretation.

In connection with the integration proceedings involving The United Gas Improvement Company, the Public Utilities Division of the Commission prepared a memorandum with respect to the meaning of Section I I (b) (I) (B) of the Act, this document being entitled "Memorandum of Public Utilities Division of Securities \& Exchange Commission to Commission, January 8, r94I. Re: Interpretation of Section I I (b) (I ) (B) -the Term 'Adjoining States.' "332 The memorandum begins with several basic postulates. In the first place it points out that Section I I(b)(I), Section 2(a)(29) and Section I (b) (4) of the Act indicate the Congressional purpose of confining the operations of utility systems to a limited area or region. Secondly, all of the integration provisions of the Act taken together indicate that Congress intended that each holding company system should be reduced to a single integrated system, and only such additional systems as might comprise small operating units in close geographic proximity to the principal system, if such operating units could not economically stand alone, and if the whole aggregation would not create a holding corporation so large as to impair the advantages of localized management or the effectiveness of regulation. Thirdly, Clause $\mathrm{B}$ was designed to eliminate a larger portion of the controversial systems by simple reference to a map. Clauses $A$ and $C$ were so worded that proof of

${ }^{333} C f$., The United Gas Improvement Company, Release No. 2500 (January $18,194 \mathrm{I}$ ). The Memorandum of January 8, 194I, was not given an official release number. See Par. 75, 123 of C.C.H. Securities Law Reporter. 
retainability thereunder might require extensive hearings, and there was danger that the range of testimony and argument in each case might be almost as extensive as the legislative hearings, which were voluminous. The repetition of such extensive hearings for each holding company system would result in colossal expenditures and interminable delays, thereby making enforcement of the Act virtually impossible. Clause B therefore affords the means of substantially narrowing the area in which proof is necessary as to how many other integrated systems are retainable by a particular holding company. However, various holding companies in the early stages of the integration proceedings were contending for an interpretation of Clause $\mathbf{B}$ which made it ineffectual as a means of limiting the factual issues in the hearings. The Public Utility Division was accordingly confronted with conflicting theories, set forth in the succeeding paragraph, which it proceeded to resolve.

The interpretation placed upon Clause $\mathrm{B}$ by the Public Utilities Division was that a company might, if it met the standards of Clauses A and C, retain integrated systems in addition to the principal system, if such additional systems were located in one or more states adjoining the states in which the principal system was located. Various holding company counsel advanced an interpretation of Clause B which would permit the retention of additional systems located in any one state of the United States, no matter how remote from the principal system in question, or in states adjoining each other but likewise remote. These two conflicting interpretations were labeled the single-area interpretation and the two-area interpretation, respectively.

The Public Utilities Division conceded that the two-area interpretation was plausible in the light of the literal wording of Clause B. However, such theory was rejected by the Division for three basis reasons, namely, (I) it was believed to be 


\section{4}

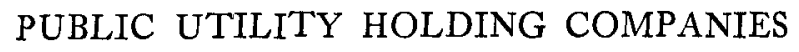

more logical to interpret the word "adjoining" in Clause B as referring to the state or states where the "single" or principal system was located, than as referring to a separate and unrelated area; (2) the two-area interpretation was inconsistent with the language of Clause $C$ and Section 2(a) (29); and (3) the two-area interpretation was negatived by the legislative history of the Act.

( I) The Division pointed out a number of illogical results of the use of the two-area theory. For example, if additional systems were located in the same state as the principal system, or in any adjoining state or states, and also in a remote state and adjoining areas, then the result would be the same under either theory, unless the additional systems in the same state as the principal system were eliminated, and the two-area interpretation would therefore not be consistently a two-area interpretation. Further, under the two-area theory, a holding company might be limited to a single system in the area where its principal system was located and where its management was concentrated, but could retain any number of systems in some remote and unrelated area, if such area consisted of one state or a group of states adjoining each other. And finally, the words "or in a contiguous foreign country" used in Clause $B$ could only be used with reference to the principal system, or with reference to the states where the principal system was located. For example, if the principal system should be located in a state adjoining Canada, while additional systems were situated next to the Mexican border in Mexico, and in Canada, the Division was of the opinion that it would be manifestly absurd to conclude that such holding company system could retain an additional system in Mexico and could not retain an additional system in Canada contiguous to the principal system.

(2) The definition of an integrated public utility system set forth in Section 2(a) (29) of the Act provides that such a 
system must be "confined in its operations to a single area or region, in one or more States, not so large as to impair (considering the state of the art and the area or region affected) the advantages of localized management, efficient operation, and the effectiveness of regulation." Clause C of Section II (b) (I) uses almost the same language, providing that "the continued combination of such systems" in any one holding company system must be "not so large (considering the state of the art and the area or region affected) as to impair the advantages of localized management, efficient operation or the effectiveness of regulation." The Division pointed out that the italicized words were in the singular, and plainly referred in both provisions to a single area or region, rather than to two areas or regions. Also, it was noted that the parenthetical clauses quoted above appear in the Act not as themselves imposing a limitation, but as a reference to a limitation elsewhere imposed. In Section 2 (a) (29) the reference is to the limitation imposed in the preceding phrase, "confined in its operations to a single area or region," whereas there is no such antecedent phrase in Clause C. The conclusion was that the antecedent limitation in this case is to be found in Clause B. Furthermore, the Division objected to the two-area interpretation because the qualification "not so large ... as to impair the advantages of localized management, efficient operation, or the effectiveness of regulation," makes no sense unless applied to the entire holding company system, and clearly connotes confinement to a single area or region. The provisions of Section I (b) of the Act describing the evils intended to be corrected, it was also noted, include the following:

“. . . it is hereby declared that the national public interest, the interest of investors in the securities of holding companies or their subsidiary companies and affiliates, and the interest of consumers of electric energy and 
natural and manufactured gas, are or may be adversely affected ... . when the growth and extension of holding companies bears no relation to economy of management and operation or the integration and coordination of related operating properties."

(3) Because of the textual difficulty in the interpretation of Clause B the Public Utilities Division was of the opinion that reference to the legislative history of the Act was appropriate. The Conference Report on the compromise bill, known as the "Barkley Compromise," containing Clause B in the same form in which it was finally enacted, described the purpose of the provisions for additional systems, as follows:

"The substitute, therefore, makes provision to meet the situation where a holding company can show a real economic need on the part of additional integrated systems for permitting the holding company to keep these additional systems under localized management with a principal integrated system. Under such circumstances the Commission is directed to permit the holding company to retain control of such additional systems, even though not physically integrated with the principal system, provided all such integrated systems are located in the same State or States, or in adjoining States or a contiguous foreign country." (Italics added) $)^{333}$

It was noted that if the antecedent of the italicized phrase was the phrase "such additional systems," then the ambiguity present in the Act was reasserted. It was argued that the more natural construction was that the italicized phrase referred

${ }^{\text {s93 }}$ Memorandum of January 8, 1941 , from the Public Utilities Division to the Commission, Re: Interpretation of section II (b) (I) (B) 一the term "adjoining States," page 16. 
to both the principal and the additional systems.

After the approval of the Conference Report by the Senate, but on the same day, Senator Wheeler, the principal exponent of the Act in Congress, made a brief statement explaining the differences betwen the Senate and House bills. The following excerpts from his statement shed some light upon the question:

“. . . After considerable discussion the Senate conferees concluded that the furthest concession they could make would be to permit the Commission to allow a holding company to control more than one integrated system if the additional systems were in the same region as the principal system and were so small that they were incapable of independent economical operation and if the combination of these small systems under one holding company would not create a corporation so large as to impair the advantages of localized management and the effectiveness of regulation. ..." ${ }^{334}$

It was shown by these and other remarks of Senator Wheeler that he deemed the Act to require that all of the systems retainable by a holding company be located in close geographic proximity to each other, thereby bolstering the interpretation placed upon Clause B by the Public Utilities Division.

Concurrently with the publication of the "single area" interpretation of Clause B by the Public Utilities Division, Chairman Jerome N. Frank of the Commission issued a statement to the public relative thereto. ${ }^{335} \mathrm{He}$ noted that the report was significant because it indicated for the first time with respect to a specific company (The United Gas Improvement Company) what the Commission tentatively believed was

334 79 CONG. RECORD I 4479 (1935).

${ }^{325} \mathrm{CCH}$ Securities Law Reporter, par. 75,124. 
meant by the geographical limitations of the Act. The Commission tentatively adopted the view that a holding company could not control several different integrated systems in several parts of the country. He pointed out that this position on the part of the Commission would greatly shorten the integration proceedings by eliminating at the outset consideration of countless remote properties.

The specific utility in question, as noted above, was The United Gas Improvement Company. In applying the standards of Clause B to the properties of that company in a preliminary and tentative decision, the Commission adopted the "single area" theory advocated by the Public Utilities Division. It was accordingly tentatively concluded that a holding company might continue to control an integrated public utility system or systems additional to the principal system if all such additional systems were located in the same state or states in which the principal system was located, or in states adjoining thereto. ${ }^{336}$ Since the principal system of The United Gas Improvement Company appeared to be located in southeastern Pennsylvania and northern Maryland and Delaware, the utility assets of the company in Arizona, New Hampshire, Tennessee, Kansas, and Connecticut could not be retained. ${ }^{337}$

The interpretation of Clause B was crystallized in an early decison relating to Engineers Public Service Company. ${ }^{338}$ The company urged the "two-area" interpretation of Clause B, while the staff of the Public Utilities Division relied upon the "single area" principle discussed above. The Commission inquired into the intent of Congress in its effort to resolve the patent ambiguity on the face of Clause $B$. The conclusion, again, was that the question of policy with respect to the

${ }^{836}$ The United Gas Improvement Company, Release No. 2500 (January 18 , 194I).

${ }^{337}$ See, also, The United Gas Improvement Company, 9 S.E.C. 52 (194I).

${ }^{323}$ Engineers Public Service Company, 9 S.E.C. 764 (194I). See map of Engineers Public Service Company system at page 42, supra. 
geographical limitation of holding company system operations had been finally determined by Congress itself and was not open for re-examination or re-determination by the Commission, and that the policy of Congress was to limit the additional systems to a state or states adjoining the state in which the principal system was located, or in a foreign country contiguous thereto. ${ }^{339}$ The inconsistent results of the application of the "two area" theory were demonstrated in this case. Under such interpretation, if the Virginia-North Carolina system was the principal system, a vast empire in the west might be retained because the western properties lay in adjoining states, but the other systems close to the VirginiaNorth Carolina system could not be retained in such case. The Commission was of the opinion that such an interpretation might be within the letter of the statute and yet not within the statute because not within its spirit nor within the intention of its makers. The absurd results which followed from such an interpretation made it unreasonable to believe that Congress so intended the law. ${ }^{340}$

The compay advanced another possible meaning for the words of Clause B consistent with the two-area theory. It was argued that if "adjoining" must be related to some antecedent contained in Section II (b) (I), then that antecedent must be the "one state" referred to in Clause B, without, however, in any way relating such "one state" to the location of the principal system. On such basis all the additional systems, whether near to or distant from the principal system, would have to be located in one state or in states adjoining such state. The Commission reduced this contention to an absurdity by assuming the location of a principal system in

${ }^{839}$ Engineers Public Service Company, 9 S.E.C. $76_{4}$ (194I).

${ }^{200}$ Citing Holy Trinity Church v. United States, 143 U.S. 457 (1892); Sorrells v. United States, 287 U.S. 435 (r932); and United States v. American Trucking Association, 3 1 o U.S. 534 (1940). 
Virginia, with other systems in Maryland and North Carolina, in which case one of the latter two could not be retained since they do not adjoin each other. On the other hand, the Virginia system could have an additonal system in California, Oregon, Nevada, and Arizona under this interpretation. Under the one-area interpretation of Clause B no such absurd results would follow. The Commission stated its position as follows:

"We concur in the suggested conclusion that 'a geographical limitation in furtherance of the integration of holding company systems that would allow the retention of systems in two distant areas, and yet prohibit the retention of two additional systems adjoining the principal system, cannot be found to be based on any rational purpose or policy consistent within itself.' An interpretation that would have that result is, we think, entirely contrary to the legislative concept of limiting holding company control to related operating properties in a restricted territory, and inconsistent with the purpose of fostering effective regulation and localized management as contemplated by the Act. ${ }^{\text {"34.1 }}$

Consequently, whether the Virginia-North Carolina system of Engineers Public Service Company or its Louisiana-Texas system was chosen as its principal system, the Commission's interpretation of Clause B precluded the retention of its properties located in Washington, the western states, and Florida. If the Virginia-North Carolina system was selected as the principal system, then the Louisiana-Texas and Texas-New Mexico properties would have to be disposed of under Clause B. If the Louisiana-Texas system was the principal system, then the properties in Virginia, North Carolina, and Georgia

${ }^{312}$ Engineers Public Service Company, 9 S.E.C. 764, 786-787 (r941). The inner quote is from the brief of the Public Utilities Division relative to the interpretation of Clause $\mathbf{B}$. 
would have to be eliminated under Clause $B$.

Upon the appeal of this case, the company contended that the incongruities that might result from the association of systems far removed from one another under the two-area interpretation would be obviated by applying Clauses $A$ and $C$, which preclude the retention of additional systems unless the Commission finds that they are needed to effectuate substantial economies and are not so large as to impair the advantages of localized management, efficient operation or the effectiveness of regulation. The United States Court of Appeals for the District of Columbia reviewed the legislative history of the Act relative to Clause B and concluded that the interpretation of the Commission was correct, admitting that the matter was not free from doubt. ${ }^{342}$ The court was also persuaded by the irrational consequences that would flow from the two-area interpretation of Clause B. The company pointed out that the one-area theory would lead to certain inequalites in some cases, since it restricts the permissible area covered by a principal system and additional systems more severely when the principal system is located in a state, such as Maine, which has few adjoining states, than it does in a state like Missouri to which eight states are contiguous. The Court answered this argument with the proposition that in the Missouri situation all the additional systems sought to be retained, which might be very numerous, would be retainable in actual practice only if it could be shown to the satisfaction of the Commission that they complied with the standards of Clauses A and B. The Court probably meant Clauses A and $C$, rather than A and B. If so, the Court tacitly adopted the argument of the company relative to the solution for the incongruities possible under the two-area interpretation of Clause B.

${ }^{342}$ Engineers Public Service Company v. Securities \& Exchange Commission, 138 F.(2d) 936 (C.A.,D.C., I 943). 
The application of Clause B to The North American Company presented an interesting problem. The electric operations of the Union group, considered by the Commission to be the principal system of the company, were carried on in Missouri, Illinois, and Iowa. ${ }^{343}$ The Commission held that Clause $\mathrm{B}$ barred the retention of the Ohio, District of Columbia, and California utility operations as additional systems. In spite of their physical separation by Lake Michigan, Michigan and Illinois were held to be adjoining states. ${ }^{344}$ Therefore, Clause $\mathrm{B}$ did not bar the retention of the Michigan and also the Wisconsin properties of the companies as additional systems.

North American attempted to justify the retention of its Cleveland, Ohio, properties as an additional system on the ground that Wisconsin adjoins Illinois, Michigan adjoins Wisconsin, and Ohio adjoins Michigan. This was characterized as the "chain" theory of Clause B. The Commission noted that this theory would permit the retention of properties from one coast of the country to the other, as long as the holding company retained property in each state of the chain of states, and rejected the contention as patently invalid.

\section{Summary of the Requirements of Clause B}

Subsequent applications by the Commission of the onearea theory of Clause B are numerous. ${ }^{345}$ However, such ap-

${ }^{343}$ The North American Company, Ix S.E.C. I 94 (1942). See map of The North American Company system at page 45, supra.

${ }^{344}$ See The Commonwealth \& Southern Corporation, Release No. 2626 (March 19, 194r), to the contrary. The Commonwealth and Southern opinion was only a tentative decision, however, and should be treated as overruled by The North American Company case.

${ }^{845}$ The more important decisions are as follows: Cities Service Company, I 5 S.E.C. 962 (1 944) (The question was raised whether a system in Arkansas, Louisiana, and Texas adjoined a Missouri-Kansas-Oklahoma-Nebraska system, since Louisiana was not adjacent to any of the latter four states. This issue was not decided, but the Louisiana properties would apparently not be retainable under the Engineers Public Service Company decision requiring additional systems to be located in the same state as the principal system, in adjoining state or states, or in a contiguous foreign country. Engineers Public Service Company, 


\section{plications have been largely automatic and do not merit ex-} tended consideration. Despite the ambiguity inherent in Clause B, the legislative history of the Act in general supports

9 S.E.C. 764 , affirmed on this point in Engineers Public Service Co. v. Securities \& Exchange Commission, I 38 F.(2d) 936 (C.A.,D.C., I 943). MissouriKansas-Oklahoma-Nebraska system adjoined by Missouri-Kansas-OklahomaArkansas system and New Mexico system. Systems in Ohio, Arizona, New York, and Canada did not adjoin Missouri-Kansas-Oklahoma-Nebraska system.) Cities Service Power \& Light Company, I4 S.E.C. 28 (I 943) (Missouri system did not adjoin Colorado, Wyoming, Arizona, or New Mexico properties. Washington, Tennessee, Virginia, Connecticut, and North Carolina properties did not adjoin Ohio, Colorado, or New Mexico systems. Washington, Virginia, Connecticut, and North Carolina utilities did not adjoin Missouri system. However, since the electric properties in southwest Missouri and adjacent portions of Arkansas, Oklahoma, and Kansas were found to be integrated, Clause B would not have barred the retention of Colorado and New Mexico properties. See map of Cities Service system at page 52, supra.) Columbia Gas \& Electric Corporation, I 7 S.E.C. 494 ( I 944) (West Virginia-Kentucky-Ohio system, Pennsylvania-West Virginia-Ohio-Maryland system, and Ohio system were mutually adjoining.) Associated Gas \& Electric Corporation, Release No. 2983 (Denis J. Driscoll and Willard L. Thorp, Trustees, September 4, 194I), and 11 S.E.C. 1115 (1942) (Utility properties in Maine, Indiana, Illinois, Virginia, Kentucky, Tennessee, North Carolina, South Carolina, Georgia, Florida, Louisiana, Arkansas, Missouri, Texas, Oklahoma, Arizona, and the Philippine Islands did not adjoin systems in New York or Pennsylvania. Properties in Delaware, West Virginia, Maryland, and Ohio did not adjoin New York systems. Connecticut and Vermont properties did not adjoin Pennsylvania system.) The Commonwealth \& Southern Corporation, Release No. 2626 (March I 9, I 941), and Release No. 7615 (August 1, 1947) (Properties in Mississippi, Alabama, Georgia, Florida, South Carolina, Illinois, and Pennsylvania did not adjoin Michigan system. Utilities in Michigan, Illinois, Ohio, Pennsylvania, and South Carolina did not adjoin Mississippi or Alabama systems. The same utilities plus those in Mississippi did not adjoin Georgia system. Michigan system did not adjoin Pennsylvania-Ohio system. Properties in Michigan, Illinois, Ohio, and Pennsylvania did not adjoin Mississippi-AlabamaGeorgia-Florida system. See map of The Commonwealth \& Southern Corporation system at page 61, supra.) Engineers Public Service Company, 12 S.E.C. 4 I (1942) (Electric system and gas system in same state, Virginia, met requirements of Clause B. Georgia system adjoined Virginia-North Carolina system. Clause B satisfied where additional system was in Louisiana or Texas and principal system was in Louisiana and Texas. Texas-New Mexico system adjoined Texas-Louisiana system. See map of Engineers Public Service Company system at page 42, supra.) The Middle West Corporation, I5 S.E.C. 309 (1 944) (Properties in Kansas, South Dakota, and Nebraska did not adjoin IllinoisKentucky or Kentucky-Tennessee-Virginia systems. Oklahoma, Texas, Louisiana, Arkansas, and Mississippi properties did not adjoin Illinois or Kentucky systems. See map of the Middle West Corporation system at page 65, supra.) Pennsylvania Gas \& Electric Corporation, Release No. 8490 (September 3, 1948) (Property in Rhode Island did not adjoin either New York or Pennsyl- 
the one-area theory of the Commission. Furthermore, it may be said that, carried to absurd extremes, the one-area principle is less incongruous than the two-area interpretation. The Commission deserves commendation for the fact that early in the interpretative history of the Act it took a clear and definite position on a difficult problem and adhered to it steadfastly throughout subsequent proceedings. The correctness of this position was affirmed two years later by the appellate court. The existence of this guidepost has been an important factor relative to integration, in that it has enabled the Commission to eliminate large quantities of evidence by mere reference to a map.

Good examples of this statement are the systems of The United Light \& Power Company and United Public Utilities Company. ${ }^{346}$ Although the companies naturally resisted the

vania. Note that Rhode Island is separated from Long Island, a part of New York state, only by Long Island Sound. By analogy to The North American Company case, I I S.E.C. 194 (1942), where Michigan and Illinois were held to be adjoining states, although physically separated by Lake Michigan, it would seem that New York and Rhode Island might well be held to adjoin each other even though Long Island Sound is a part of the Atlantic Ocean rather than one of the Great Lakes.) Standard Power \& Light Corporation, 9 S.E.C. 862 ( I 94I), and Release No. 8242 (June I, I 948) (Properties in Oregon, California, Kentucky, Indiana, Washington, Idaho, Wyoming, North Dakota, South Dakota, Montana, Minnesota, Illinois, Wisconsin, Iowa, Arkansas, Oklahoma, Colorado, Michigan, and Mexico did not adjoin Pennsylvania and West Virginia systems. Pennsylvania and West Virginia systems did adjoin.) The United Light \& Power Company, Release No. 2820 (June I3, I 94I), and 9 S.E.C. 833 (1941) (Systems in Ohio, West Virginia, and Texas did not adjoin system in Kansas and Missouri. Systems in Missouri, Kansas, Iowa, Nebraska, and Oklahoma met the requirements of Clause $B$ relative to $M$ issouri-Kansas system. Texas system did not adjoin system in Michigan and Wisconsin. Michigan, Wisconsin, Texas and Indiana properties did not adjoin Missouri-Kansas system. Also, see The United Light \& Railways Company, I4 S.E.C. 3 (1943).) United Public Utilities Corporation, Release No. 3105 (October 31, I94I), and I I S.E.C. 33 ( I 942) (Arkansas property did not adjoin Ohio-Indiana or North DakotaSouth Dakota systems. Ohio-Indiana system did not adjoin North DakotaSouth Dakota system, and vice-versa.)

${ }^{346}$ The United Light \& Power Company, Release No. 2820 (June I 3, I 941), and 9 S.E.C. 833 (1941); The United Light \& Railways Company, I 4 S.E.C. 3 ( I 943); United Public Utilities Corporation, Release No. 3 I $0_{5}$ (October 31, I 94 I), and I I S.E.C. 33 (1942). 
one-area theory at the outset, the firm position of the Commission enabled them to see at a glance that extensive and expensive efforts to support the retainability of remote properties would be futile. ${ }^{347}$

\section{The Size Requirement: Localized Management, Efficient Operation, and Effectiveness of Regulation}

The third of the cumulative prerequisites under the Act relative to the retention of additional systems requires that the continued combination of such systems under the control of the holding company shall not be so large, considering the state of the art and the area or region affected, as to impair the advantages of localized management, efficient operation, or the effectiveness of regulation. ${ }^{348}$ Identical language in Section 2(a) (29)(A) and Section 2(a) (29)(B) of the Act has already been noted and discussed at length in Chapter II, above, relative to the standards of integration as applied to particular electric and gas utility systems. It was there noted that the factors of localized management, efficient operation, and effective regulation are largely subordinate in importance to the other requirements for integration. In the treatment of the problem of additional systems, the size requirements of Clause $\mathrm{C}$ have not played a major part. Most of the proposed additional systems have been eliminated at the outset by the geographical requirements of Clause B; if such systems survived Clause $B$, then they were subjected to the substantial economies test of Clause $A$, which resulted in further drastic eliminations. It has been very seldom that a proposed additional system which met both of such tests has been subjected to close scrutiny under Clause $C$. However, the pertinent cases are discussed below.

947 Blum, Robert, "SEC Integration of Holding Company Systems," I 7 Journal of Land \& Public Utility Economics, 423 ( I 941 ).

${ }^{348}$ Section 11 (b) ( 1 ) (C), referred to herein as "Clause C." 


\section{The North American Company}

The various electric utility systems of The North American Company were among the first to be scrutinized by the Commission in the light of the requirements of Clause C. ${ }^{349}$ Such systems centered around St. Louis, Missouri, East St. Louis, Illinois, eastern Wisconsin, Detroit, and Cleveland, respectively. Previously, in its analysis of the single area and twoarea theories with respect to Clause $\mathrm{B}$, the Commission had pointed out that Clause C referred to the "area or region," in the singular, in which the principal and additional systems were to exist. ${ }^{350}$ Furthermore, it was the opinion of the Commission that one of the basic objectives of the Act was to eliminate each holding company system operating in diverse and distant areas, as evidenced by the legislative history set forth in the study of Clause B. The conclusion was that the singular reference to "area or region" in Clause $\mathrm{C}$ and such legislative history prevented the retention of additional systems where such retention would result in the control by the same interests of unrelated properties in widely separated areas. ${ }^{351}$ The Commission was also of the opinion that the fact that the language in Section 2(a) (29) of the Act was almost identical to that of Clause $\mathrm{C}$ necessitated similar interpretations of the two provisions, and also indicated that the considerations involved in applying the size standards of Clause $\mathrm{C}$ to a combination of principal and additional systems were similar to those involved in applying the size standards of Section 2(a)(29) to determine the maximum limits of a single integrated system. ${ }^{352}$

It was noted that Milwaukee and St. Louis were 285 miles

${ }^{349}$ See map of The North American Company electric utility system at page 45, supra.

${ }_{350}$ Engineers Public Service Company, 9 S.E.C. 764, 787 (I 94 I).

${ }^{361}$ The North American Company, i I S.E.C. 194 (1 942 ).

${ }^{352}$ Citing United States v. Cooper Corporation, 3 I 2 U.S. 600 (194I). 
apart; that Detroit and St. Louis were $4 \mathrm{I} 5$ miles apart; and that Cleveland and St. Louis were 424 miles apart. Each of The North American Company systems operating in the vicinity of these cities was a vast enterprise. The St. Louis properties in 1939 had 249,096 customers in an area of 3,100 square miles. The eastern Wisconsin properties had 250,770 customers in an area of 8,289 square miles. The Cleveland system had 330,000 customers in an area of 1,700 square miles. The number of customers and the area served by the properties centering around Detroit were not shown, but they appear to be considerably larger than the Cleveland figures, and perhaps slightly smaller, particularly as to area served, than the eastern Wisconsin statistics. The property and plant account of The Detroit Edison Company as of June 30, 1940, was $\$ 327,6$ I 9,644 before deduction of reserves. It was found that each of these cities was the focal point of a different area or region, in a geographical, sociological, and operational sense. North American argued that the management of each of these subsidiaries was local in character. The Commission felt that the test did not lie in the current status of management, whether localized or centralized, since the policy of the company in this respect could be changed at will. The requirement was the size and the area or region affected, not the policy of a particular management group. Consequently, it was held that a combination of either the eastern Wisconsin, the Detroit, or the Cleveland properties with the St. Louis (Union) group would not satisfy Clause C. ${ }^{353}$

The application of Clause $C$ to the gas utility properties of The North American Company was also in issue. ${ }^{354}$ One of its subsidiaries, Northern Natural Gas Company, was in turn the parent of two gas utility companies, Argus Natural Gas Company, Inc., and Peoples Natural Gas Company, operat-

\footnotetext{
${ }^{353}$ The North American Company, I I S.E.C. I 94, 2 I 5 (1942).
}

${ }^{254}$ See footnote 228 , supra. 
ing in Kansas, Nebraska, Iowa, and Minnesota. The Commission was of the opinion that the centralized control exercised by Northern Natural Gas Company over these companies did not leave to each of them the advantages of localized management. The evidence merely showed divisional maintenance, location of local offices, and localization of retail activities. The Commission stated its position as follows:

"... When in fact management is highly centralized, as it is in Northern's main office at Omaha, and there is no evidence as to the local nature of important policy determinations, we cannot find that the advantages of localized management are not impaired by central control. We believe that under Clause (C) no combination of systems should be permitted which would impair true localization of management and policy making. Otherwise, as is the case in the area in which Northern operates, small communities are pitted against strong 'absentee control' with respect to matters vitally affecting the interests of the communities. Insofar as possible, we are required under Section I I (b) ( I) to insure local management responsive to local needs and local public feeling." ${ }^{355}$

${ }^{355}$ The North American Company, I I S.E.C. 194, 237 (1 942). Senate Report No. 621, 74th Congress, ist Session (1935), pointed out at pages I $1-12$ that one of the purposes of the Act was "to confine the operations and interest of each public utility system to the actual utility business of a given region so that the system will have to work out a modus vivendi with the population of that region. ... A far-flung disjointed system is independent and absentee so far as any particular community in its system is concerned. Its management has the problems of no one community for its exclusive consideration. It derives a great portion of its power and its profits from outside sources over which the community has no control. It can never be successfully regulated by the community it serves. ...

"An operating system whose management is confined in its interest, its energies, and its profits to the needs, the problems, and the service of one regional community is likely to serve that community better, to confine itself to the operating business, to be amenable to local regulation, to be attuned and responsible to the fair demands of the public, and, more often, to get along with the public to mutual advantage. . . . Essentially local systems will tend to operate utilities rather than to play with high finance; and essentially local 
The main operating areas of Illinois Iowa Power Company, a subsidiary of The North American Company, in Illinois were held to be integrated, but four smaller electric utility systems of Illinois Iowa in the same state were held not to be parts of the principal system, although each of the four constituted an integrated system within itself. ${ }^{356}$ Illinois Iowa sought to retain each of these as additional systems. The five properties combined served $217,57 \mathrm{I}$ customers in an area of 15,233 square miles with a population of 750,000 . It was held that the combination of the four smaller systems with the prinicipal system of Illinois Iowa under the control of a single holding company was not so large as to impair the advantages of localized management, efficient operation, and the effectiveness of regulation under Clause $\mathrm{C}^{357}$ It was also contended by Illinois Iowa that the integrated system of Des Moines Electric Light Company, operating in the state of Iowa, was retainable as an additional system. It was held that the requirements of Clause $\mathrm{C}$ were not met in this instance. It appeared that Iowa companies were subject to regulation by the Iowa State Commerce Commission in certain respects, but not with regard to rates, which were subject to negotiation with the individual communities served. The Commission believed that the absence of central regulation made it particularly necessary to apply rigorously the standards of Clause $\mathrm{C}$ in order to assure the localization of each system's policy determinations. The control of policy, it was felt, by men who were not in their daily business activities responsive to local public opinion, and the disadvantages of the local communities as opposed to the holding company with its great

enterprise is far less likely to accumulate a disproportionate amount of political and economic power."

${ }^{356}$ See map of The North American Company electric utility system at page 45, supra.

${ }_{887}$ The North American Company, I I S.E.C. I 94, 244 (1942). 
resources in the matter of regulation resulted in the impairment of effective public regulation, contrary to the principles set forth in Section $I(b)(5)$ of the Act. ${ }^{358}$

\section{Engineers Public Service Company}

In the Engineers Public Service Company case the question arose whether Savannah Electric \& Power Company, operating in the state of Georgia, could be retained as a system additional to the Virginia Electric \& Power Company system in Virginia and North Carolina. ${ }^{\mathbf{3 5 9}}$ The company suggested that Clause $\mathrm{C}$ did not refer to geographical conditions, since such conditions were imposed by the Act in Clause B. This suggestion was rejected, the Commission stating its position as follows:

". . . While these clauses impose separate conditions, these conditions do not set up mutually exclusive types of standards. The fact that Clause (B) is concerned with certain geographical considerations does not mean that all geographical factors are excluded from the scope of the other two clauses. And, in fact, the words, 'not so large (considering the .... area or region affected) ...,' indicate the existence of geographical considerations to be taken into account in applying the standards of Clause (C). The relevance of such considerations in the sensible application of the clause is manifest. The clause is concerned with the effect of the size of a combination of integrated public utility systems on the advantages of localized management, efficient operation, and effectiveness of regulation. The magnitude of the distances and differences between the service areas of the components of the combination clearly has some bearing upon the possibility of obtaining for the com-

${ }^{858}$ The North American Company, I I S.E.C. I 94, 245 ( I 942 ).

${ }^{259}$ See map of Engineers Public Service Company electric system at page 42, supra. 
bination the advantages of localized management, efficiency of operations and effectiveness of regulation. It is almost too obvious to need explicit statement that, other things being equal, the advantages of localized management, for example, are less likely of achievement in a combination whose properties are separated by 450 miles than in a combination of adjacent properties. Of course, the fact that the geographical factors must be considered in determining whether a combination is too large does not mean that an examination of the size of the physical properties, plant account, revenues or income is not also apposite in treating the requirements of Clause (C)."

It was also observed that the legislative history of the Act supported this position. ${ }^{361}$ Consequently, it was concluded that the geographical restrictions of Clause $C$ supplemented the automatic limitations of Clause $\mathrm{B}$ based upon state boundaries in effectuating the purposes of the Act.

The electric systems of Virginia and Savannah were 3 I 5 miles apart at the closest points and 525 miles apart at the most distant points. Their executive offices were 443 miles apart. The service area of Savannah was surrounded by marshy, uninhabited territory. The industrial and agricultural life of Virginia's service area had little economic relationship with that of Savannah. The Commission was convinced that an awareness of and sensitivity to the problems of the population of Savannah were not likely to exist in a management centered in Richmond, Virginia, and, accordingly, that a finding could not be made that the combination of these two sets of properties was not so large as to impair the advantages of localized management. The requirements of Clause $\mathrm{C}$ were

${ }^{880}$ Engineers Public Service Company, 12 S.E.C. 41, 65-66 (1 942 ).

${ }^{801}$ Engineers Public Service Company, I2 S.E.C. 41, 66 (1942), citing Senate Report No. 621, 74th Congress, 1st Session (1935). 
therefore not met in this instance. ${ }^{362}$

Engineers Public Service Company also sought a ruling to the effect that the electric properties of El Paso Electric Company might be retained as an additional system to the properties of Gulf States Utilities Company. The Service area of Gulf was composed of 27,000 square miles in southwest Louisiana and southeast Texas. Of the 270 communities served, $92.2 \%$ had a population of less than 2,500, and its service area was essentially rural. The region's economic character was primarily agricultural, but the production, refining and distribution of oil and gas consumed considerable electric power. El Paso, on the other hand, served an area of 700 square miles in west Texas and southeast New Mexico. Except for the city of EI Paso, its system was confined to a narrow valley surrounded by mountains and desert and was also largely pastoral in its economic character. There was no operating relationship between the two systems. There was little intercourse between their service areas and little in common, geographically, politically, or economically. The two areas were 500 miles apart at their closest points and I,000 miles apart at their farthest points. Their principal offices were 750 miles apart. In view of these facts, it could not be found that the combination of Gulf and El Paso would not be so large as to impair the advantages of localized management.

Further, with regard to the effectiveness of regulation in connection with this proposed combination, it was observed that the properties involved were scattered over three states. In Louisiana and New Mexico the properties were subject to the respective state public service commissions. However, in Texas regulation depended upon the municipalities served and the state district courts which had jurisdiction to declare unreasonable rates illegal. The Commission felt that a com-

${ }^{862}$ Engineers Public Service Company, I2 S.E.C. 41, 67 (1942). 
bination which could be locally regulated only by so scattered and diverse a group of regulatory bodies probably did not meet the size requirement of Clause $C$ with respect to effectiveness of regulation.

The holding company advanced the argument that because the combined electric plant account of Gulf and El Paso was not as large as that of Virginia Electric \& Power Company, which had been held to be a single integrated electric utility system, the combination of Gulf and El Paso could not be too large under Clause $\mathrm{C}$. The Commission did not agree. It was of the opinion that the "state of the art and the area or region affected" must be considered in this connection. Although the area or region affected by Virginia might be such as not to render Virginia's size unduly large, yet it was held that it did not mechanically follow that a combination which was smaller in the magnitude of its financial operation was not, in another area or region, so large as to violate the principles of Clause C. The Commission accordingly would not accede to the theory that any combination whose financial magnitude was smaller than any utility system that had been found to be integrated must ipso facto be not so large as to violate the standards of Clause C. Consequently, it was held that the proposed combination of Gulf and El Paso did not meet the requirements of Clause $\mathrm{C}^{363}$ It was conceded, however, that the electric property at Van Horn, adjacent to the El Paso properties but physically separate and distinct, met the test of Clause $\mathrm{C}$ in combination with the El Paso system in view of its small size and geographical proximity. ${ }^{364}$

The Engineers Public Service Company system also raised another interesting problem under Clause $\mathrm{C}$. It will be recalled that the Commission, after some vacillation, had taken the position that electric and gas properties could not

\footnotetext{
${ }^{863}$ Engineers Public Service Company, I 2 S.E.C. 4I, 89 (1942).

${ }^{304}$ Engineers Public Service Company, I2 S.E.C. 4I, 90 (1942).
} 
be retained together as a single integrated system. This relegated the owners of such electric and gas combinations to the doubtful solace of the $A B C$ clauses. In addition to its electric utility business, Gulf States Utilities Company also distributed natural gas to customers in Baton Rouge, Louisiana, and its suburbs, a territory of about 15 square miles in an area with a population of 70,000 . It operated 169 miles of gas mains. On January I, I94I, the company had I2,542 gas customers. As of December 3I, 1940, the utility plant account of the gas system was $2.8 \%$ of the total for Gulf; the operating revenues for the year 1940 of the gas system were $5.9 \%$ of the total of the system; and its net income for that year was $5.3 \%$ of the total. It was held that the gas system constituted an integrated utility system, and, further that it met the requirements of Clause $C$ in connection with the electric properties of Gulf. ${ }^{365}$ It was noted that all of the gas customers of Gulf were also electric customers and that the service area of the gas system was not an addition to the electric service area, but merely coincided with part of it. The financial size of the gas system was small in comparison with the electric system. The rates and services of both the gas and electric systems in Louisiana were under the jurisdiction of the Department of Public Service of Louisiana.

Engineers Public Service Company also sought to retain the integrated gas utility system of Virginia Electric \& Power Company, in addition to the integrated electric utility system of Virginia. The gas system consisted of a gas manufacturing plant located at Norfolk, Virginia, and a distribution system serving an area of approximately 35 square miles in and around Norfolk. As of July I, I 94I, the gas system had 29,363 customers and 357 miles of mains. It was located

\footnotetext{
${ }^{205}$ Engineers Public Service Company, 12 S.E.C. 41, 79 (1942). The gas utility system also met the requirements of Clause $B$, but failed to meet the test of Clause $A$.
} 
wholly within the I 3,500 square miles of electric service area of Virginia. The gas plant account of Virginia was $8.9 \%$ of its electric plant account; its gross operating revenues from gas were $7.1 \%$ of its electric revenues for 1940. Both the gas and the electric systems were subject to regulation by the Virginia State Corporation Commission, which had authority to fix rates and regulate the issuance of securities and the keeping of accounts. The Commission found that this was not a prohibitively large combination and was permissible under Clause $\mathrm{C}^{366}$

\section{Southern Union Gas Company}

In addition to its principal gas utility system located in west Texas and New Mexico, Southern Union Gas Company also operated gas properties in central Texas, south Texas, and central Oklahoma. These latter properties were 250,350, and 300 miles, respectively, from the nearest points of the principal system. The Commission felt that the advantages specified in Clause $\mathrm{C}$ would sooner be attained by the concentration of the management's time and efforts in the area served by the principal system than by being spread over such system plus the three sets of outlying properties. Accordingly, a finding of compliance with Clause $C$ in regard to a combination of these properties was denied. ${ }^{367}$ This finding was novel in that it is one of the exceptionally few situations where retention of additional systems was denied on the basis of Clause $\mathrm{C}$ alone, the usual situation being the invocation of Clause $\mathrm{C}$ to bolster a finding of non-compliance with Clause A.

${ }^{366}$ Engineers Public Service Company, i2 S.E.C. 4I, 57 (1 942 ). Here again, however, the retention of the gas property as an additional system was denied under Clause $\mathrm{A}$.

${ }^{367}$ Southern Union Gas Company, I2 S.E.C. I 16, I 42 (1942). 


\section{Lone Star Gas Corporation}

Lone Star Gas Corporation, whose principal gas utility system was located in the north central portion of the State of Texas and adjoining portions of the State of Oklahoma (identified as its "Central System"), also controlled gas systems in the cities of El Paso and Galveston, Texas. Such latter systems had been excluded from the integrated Central System for the reason, among others, that they were not in the same area or region as the Central System within the meaning of Section 2(a) (29)(B) of the Act. ${ }^{368}$ Although there was no finding that each of these smaller systems was individually integrated, they were tested for retainability under the $\mathrm{ABC}$ clauses. The Commission invoked the rule of The North American Company case, to the effect that the size standards imposed by Section 2(a) (29)(B) and Clause $\mathrm{C}$ should be similarly construed. ${ }^{369}$ The Galveston property was 250 miles from Dallas, the headquarters of the Central System, and 125 miles from College Station, the nearest town served by the Central System. The El Paso system was 700 miles from Galveston, 575 miles from Dallas, and 350 miles from the nearest town served by the Central System. Other non-affiliated gas systems operated in the intervening areas. Since the El Paso and Galveston properties had been held to be outside of the area or region of the Central System properties for the purpose of Section 2(a)(29)(B), it followed that they were also outside for the purpose of Clause C. ${ }^{\text {370 }}$

Furthermore, the gas operations in El Paso and Galveston were subject to a high degree of supervision by the management at Dallas. Most of the policies with respect to the relations of the company with customers, with governmental

${ }^{388}$ Lone Star Gas Corporation, I 2 S.E.C. 286 (1942).

${ }^{369}$ The North American Company, I I S.E.C. I 94 ( 1942 ).

${ }^{870}$ Lone Star Gas Corporation, 12 S.E.C. 286, 295-296 (I 942 ). 
authorities, and with employees were determined in Dallas. Depreciation policies, rate policies, and budgets were supervised in Dallas. The Commission felt that where operations were located at a substantial distance from the management, as they were in El Paso and Galveston, and supervision by absentee management was present in the degree indicated in this case, it was not likely that the advantages of localized management were reflected in operations and doubted that such management was responsive to local needs and local public feeling. Further, the Commission believed that regulation was less effective when management was absent from the situs of operations and the location of the regulatory authorities, it being noted that the municipalities of El Paso and Galveston controlled the rates of their respective gas systems. Consequently, it was found that the standards of Clause $\mathrm{C}$ had not been met. ${ }^{371}$

\section{Cities Service Power $\mathcal{G}^{2}$ Light Company}

Cities Service Power \& Light Company contended that all of its electric utility properties in the Rocky Mountain group could be retained either as a single integrated system or as a principal system and systems additional thereto. ${ }^{372}$ These properties were located in the States of Wyoming, Colorado, New Mexico, and Arizona. The north to south extremes of these properties were 900 miles apart. The property in northern Wyoming was 240 miles from the nearest sertion of the remainder of the system. Tucson was 320 miles from the nearest of the other properties of the system, and Deming was 200 miles therefrom. All of the intervening stretches of territory between these properties were mountainous and sparsely settled. After holding that such a combination of properties did not meet the size stand-

${ }^{871}$ Lone Star Gas Corporation, I 2 S.E.C. 286,296 (x 942 ).

${ }^{972}$ See map of Cities Service Power \& Light Company electric system at page 52 , supra. 


\section{PUBLIC UTILITY HOLDING COMPANIES}

ards of Section 2(a)(29)(A) of the Act, the Commission again referred to the principle of The North American Company case that highly similar standards as to size exist in Clause $\mathrm{C}^{373}$ It was stated that "The statute and its legislative history make it clear that, consistently with geographic conditions (in the broad sense of that term) as much compactness should be achieved in outlining the spheres of holding company influence as physical facts permit.. ${ }^{374}$ The company urged that the Commission find that the States of Wyoming, Colorado, New Mexico, and Arizona were located in a single area or region within the meaning of the Act. This interpretation of the Act, in the eyes of the Commission, would comprehend hegemonies of holding company control so vast that, under the area or region standard, the Act would permit a few holding companies to divide the country, contrary to the intent of Congress. ${ }^{375}$ In view of their scattered location and their remoteness from the central body of compact properties of the system, the properties in Sheridan, Wyoming, Deming, New Mexico, and Tucson, Arizona, were held to be not within the same area or region with the remainder of the system properties or with each other within the meaning of Section 2(a) (29) (A) of the Act. ${ }^{376}$ However, in view of the fact that certain interconnections between the main body of the system and the Deming and Tucson properties were contemplated, jurisdiction was reserved as to these two properties.

Federal Light \& Traction Company, a subsidiary of Cities Service Power \& Light Company, was the parent of all of the Rocky Mountain group of Cities Service properties except Public Service Company of Colorado. Subsequent to the fore-

${ }^{373}$ The North American Company, I I S.E.C. I94 ( 1 942).

${ }^{374}$ Cities Service Power \& Light Company, 14 S.E.C. 28, 59 (1943).

${ }^{375}$ Cf., Senate Report No. 62 I, 74th Congress, Ist Session, page I 2 (1935).

${ }^{879}$ Cities Service Power \& Light Company, I4 S.E.C. 28, 60-6I (I943). 
going proceedings, Federal Light \& Traction Company filed a plan of reorganization under Section I I (e) of the Act for compliance with Section II (b). ${ }^{377}$ The plan proposed that Federal and its subsidiaries operating in Arizona, New Mexico, and Colorado be merged or consolidated into the Tucson Gas, Electric Light \& Power Company. The properties of this system from Walsenburg, Colorado, to Belen, New Mexico, had been held to constitute an integrated electric utility system in the decision disçussed above. ${ }^{378}$ Certain interconnecting transmission lines were proposed which would connect the Deming properties with the lines of the principal system at Belen and which would connect the Deming properties with the Tucson system. The extremes of the three systems were 600 miles apart in a straight line and many more miles distant by transmission line. Three states were involved with the resulting divergence of local regulation. The Commission held that, although it gave no definite weight to distance as such, the accumulation of negative factors persuaded it that the Tucson properties did not meet the requirements of Clause $C .^{379}$

A contrary decision was reached with regard to the Deming property. The net utility plant of the Deming company was $5 \%$ of the net utility plant of the principal system. Its gross operating revenues were $7.7 \%$ and its net income was $8.5 \%$ of the comparable figures of the principal integrated system. In view of its small size and proximity (about Ioo miles) to the main properties of the system, the Commission was satisfied that it met the requirements of Clause $\mathrm{C}$ as an additional system thereto. ${ }^{380}$

${ }^{377}$ Cities Service Power \& Light Company, 15 S.E.C. 247 (1944).

${ }^{978}$ See map of the Cities Service Power \& Light Company system at page 52, supra.

${ }^{380}$ Cities Service Power \& Light Company, 55 S.E.C. 675,683 ( 1944$)$.
Ibid. 


\section{The Middle West Corporation}

In The Middle West Corporation integration proceedings it was held that the properties of Central Illinois Public Service Company in Illinois and the western Kentucky properties of Kentucky Utilities Company constituted a single integrated system, and that the central and eastern Kentucky, Virginia, and Tennessee properties of Kentucky Utilities Company constituted another integrated system. ${ }^{381}$ These two integrated systems were identified as the "Northern Properties." In between them lay the properties of the Midland United Company system. The latter company was undergoing a reorganization. Middle West contended that the Northern Properties and those of Midland United together formed a single integrated system. In view of the reorganization proceedings, the Commission reserved jurisdiction to pass upon this question at a later date. However, Middle West requested a finding that the electric properties of Wisconsin Power \& Light Company, operating in the central and southern portion of the State of Wisconsin, and the electric properties of Lake Superior District Power Company in northern Wisconsin and Michigan constituted retainable additional systems to the Illinois and Kentucky systems. Wisconsin Power served an area roughly I 90 miles from north to south and Ioo miles from east to west, and its electric plant account and electric revenues were comparable in size to those of Kentucky Utilities and around a third less than those of Central Illinois. Lake Superior District was about $20 \%$ as large as Wisconsin Power in these respects. The electric properties of Lake Superior District and Wisconsin Power combined extended from the northern to the southern boundary of Wisconsin, a distance of approximately 300 miles. The distance from Lake Superior to east Kentucky was about 900

\footnotetext{
${ }^{381}$ See map of The Middle West Corporation system at page 65 , supra.
} 
miles. After considering the extent of these properties in conjunction with that of other properties in the area, the marked differences in the territories served, and the fact that a gap of I 25 miles separated the service areas of Central Illinois and Wisconsin Power, the Commission refused to find that common control of the Wisconsin companies would not impair the advantages of localized management. ${ }^{382}$

Further with regard to the Middle West properties, the Commission held that the southern group of properties in Oklahoma, Arkansas, Louisiana, and Texas was so widely separated from the Central Illinois and Kentucky Utilities properties, and so unrelated thereto, that it could not be found that its retention along with the Northern Properties would not impair the advantages of localized management. ${ }^{383}$

Before leaving the Middle West system, attention should be directed to the principal system discussion of the southwestern properties of Middle West in Chapter II, supra. These properties were located in the States of Texas, Oklahoma, Arkansas, and Louisiana and extended I,200 miles from one end to the other. They constitute the largest aggregation of utilities, geographically speaking, that have yet been approved as a single integrated system or as a principal system and systems additional thereto. Although Clause $\mathrm{C}$ was not involved in this decision, the identical language of Section 2(a)(29)(A) of the Act was applicable, and therefore the liberal application of such size standards here is pertinent in the analysis of Clause C. Such liberality in the interpretation of the size requirements was an important deviation from the narrow construction applied in the earlier cases, as discussed herein.

${ }^{882}$ The Middle West Corporation, I 5 S.E.C. 309,320 (1944).

${ }^{893}$ The Middle West Corporation, 15 S.E.C. 309, 344 (1944). 


\section{Columbia Gas E' Electric Corporation'}

In the case of Columbia Gas \& Electric Corporation, it was held that the three groups of natural gas utilities of the company centering around Charleston, West Virginia, Pittsburgh, Pennsylvania, and Columbus, Ohio, each constituted a separate integrated system. The relative financial sizes of these three groups are shown by the following figures reflected in the December 31, I943, annual statements of the companies involved: $:^{384}$

\begin{tabular}{|c|c|c|c|}
\hline & $\begin{array}{c}\text { Charleston } \\
\text { Group }\end{array}$ & $\begin{array}{c}\text { Pittsburgh } \\
\text { Group }\end{array}$ & $\begin{array}{l}\text { Columbus } \\
\text { Group }\end{array}$ \\
\hline Gross Utility Plant & $\$ 139,507,206$ & $\$ 101,681,506$ & $\$ 117,216,847$ \\
\hline Net Utility Plant & $84,423,449$ & $61,589,894$ & $87,666,6$ I 2 \\
\hline Gross Revenues & $38,641,300$ & $26,001,815$ & $35,388,7 \times 3$ \\
\hline Net Operating Revenues & $4,517,021$ & $2,444,870$ & $4,359,390$ \\
\hline
\end{tabular}

It is thus apparent that these properties were roughly comparable in size and that all of them were large in scope of operations. The facilities of the three groups were interconnected and there was a close operating relationship among them. Drilling, production, storage, and transmission operations were coordinated with the requirements of the various systems in order to obtain a maximum use and conservation of the available gas resources. Such advantages appeared to the Commission to be particularly significant in view of the rapid depletion of the natural gas resources in the Appalachian area. Retention of these properties under common control would permit a continuation of such coordinated operations, which were subject to the supervisory jurisdiction of the Federal Power Commission and the three respective state commissions. The Commission believed that the "unique circumstances" of this case justified the retention of the three groups of companies under Clause $\mathrm{C}$, in spite of the fact that the size of these properties, both absolutely and relatively,

${ }^{23 s}$ Columbia Gas \& Electric Corporation, 17 S.E.C. 494, 503, 505 and 507 (1944). 
might otherwise have led to the conclusion that separation was essential under the Act. ${ }^{385}$ The expression "relatively" referred to the principle laid down in the Cities Service Company case that, generally speaking, the $\mathrm{ABC}$ clauses contemplated additional systems junior in importance to the principal system and dependent upon the continuation of joint control with such system. ${ }^{386}$ Although these three groups of properties may well have constituted one integrated gas utility system, as pointed out in Chapter II, it does not appear that ample justification existed here for the Commission to abandon its customarily strict interpretation of Clause $C$. This decision was further indication of the weakening of the Commission's narrow application of the $\mathrm{ABC}$ clauses.

\section{American Gas $\mathcal{E}$ Electric Company}

The extensive limits of the Central System of American Gas \& Electric Company, operating in the States of Michigan, Indiana, Ohio, Virginia, West Virginia, Tennessee, and Kentucky, and the controversy in connection with the size standards of Section 2(a) (29)(A) of the Act as applied thereto, have been described in the principal system discussion of the company. ${ }^{387}$ Briefly stated, the Central System in 1944 served 749,899 customers in 1,706 communities and encompassed an area of 90,000 square miles with a population of $3,018,000$. This vast system was held to constitute a single integrated electric utility system, although it was observed that such system approached the maximum size permissible under the Act. This was an unusually generous concession in the light

${ }^{855}$ Columbia Gas \& Electric Corporation, I7 S.E.C. 494,5 I I (1 944). In view of the subsequent extension of natural gas pipe lines into this area from Oklahoma and Texas, it would seem that one of the "unique circumstances" leading to this decision, the depletion of the natural gas resources, has been largely eliminated.

${ }_{387}$ Cities Service Company, I 5 S.E.C. 962 (1 944 ).

${ }^{287}$ See map of the American Gas \& Electric Company system at page 78 , supra. 
of the earlier restrictive applications of the size requirements.

In addition to the Central System, American Gas \& Electric Company sought to retain its South Jersey system, operating in New Jersey, and its Northeast Pennsylvania System, operating in that state. The South Jersey System served I04,805 electric customers in 225 communities with a population of 308,000 in 1 944. The Northeast Pennsylvania System served 78,469 electric customers in 57 communities with a population of 344,000 in 1944. Comparative financial figures for the three systems of the company for the year ending December 3 r, I944, are set forth below:

$\begin{array}{lccc} & \text { Central } & \text { South Jersey } & \begin{array}{c}\text { Northeast } \\ \text { Pennsylvania } \\ \text { System }\end{array} \\ & \text { System } & \text { System } & \begin{array}{c}\text { System } \\ \text { Gross Utility Plant }\end{array} \\ \text { Net Utility Plant } & \$ 442,613,062 & \$ 46,006,729 & \$ 28,072,396 \\ \text { Gross Revenues } & 332,462,421 & 33,158,876 & 14,056,843 \\ \text { Operating Income } & 102,198,514 & 10,661,915 & 6,956,846 \\ & 21,386,205 & 2,201,788 & 1,715,052\end{array}$

The South Jersey System was I 85 miles from the nearest extremity of the Central System and the Northeast Pennsylvania System was 240 miles therefrom. Considering the extent and size of the Central System and the extent and size of the South Jersey and Northeast Pennsylvania systems in conjunction with the Central System, the nature of the territories served, and the distances separating the three systems, the Commission held that common control of the three systems would impair the advantages of localized management and therefore that the two smaller systems were not retainable as additional systems to the Central system under Clause C. ${ }^{388}$

\section{The Commonwealth EO Southern Corporation}

The principal utility system of The Commonwealth \& Southern Corporation, as defined by the Commission, em-

${ }^{388}$ American Gas \& Electric Company, Release No. 6333 (December 26, 1945), mimeo. page 23 . 
braced 94, 59 square miles with an estimated population of $4,700,000$ and 653,726 customers as of November 30, I $946 .^{389}$ As of September 30, I946, the gross property accounts of the companies involved amounted to $\$ 459,729,103$, and the net property accounts amounted to $\$ 373,357,728$. Their electric operating revenues for the twelve months ended on said date totalled $\$ 77,570,768$, and their net operating revenues were $\$ 2 \mathrm{I}, 504,840$. Consequently, the Commission was of the opinion that this combination of properties approached the maximum size consistent with the standards of localized management, efficient operation, and effective regulation contained in Section 2(a)(29)(A) and Section I I (b) (I) of the Act, as has previously been noted in the discussion of the principal system of Commonwealth \& Southern.

Adjoining the principal system of Commonwealth \& Southern on the east were the properties of South Carolina Power Company, another subsidary of Commonwealth \& Southern. The latter company did not seek to retain the South Carolina system, either as part of the principal system or as a system additional thereto, and agreed to divest itself of its interest in that company, but nevertheless the Commission examined the South Carolina properties in the light of the size requirements of Section 2(a)(29)(A) and Clause $C$. It was found that the efficient operation of the properties in the principal system arising from coordinated control thereof did not extend to the South Carolina system also, and the operating efficiency which moved the Commission to permit the combination of four of the southern systems as one integrated system was not effective enough in relation to the South Carolina property to permit its retention as part of the principal system or as an additional

${ }^{889}$ See map of The Commonwealth \& Southern Corporation system at page 6I, supra. 
system. Consequently, the Commission held that the addition of the South Carolina properties to those of the principal system would violate the size standards of Section 2(a) (29) (A) and Clause C. ${ }^{390}$ This was a rather obvious conclusion, the only questionable matter being whether the principal system by itself came within the true spirit of the size limitations of the Act.

\section{Summary of the Requirements of Clause $C$}

The best that may be said for Clause $C$, in the light of its interpretation by the Commission, is that it imposes a relative test of size, rather than a fixed test as exemplified by Clause $B$, for the retention of additional systems. The parenthetical phrase of Clause $C$, "considering the state of the art and the area or region affected," has been construed by the Commission to give a great deal of leeway in the application of the standards of that clause to a particular system. One important effect of this principle of relativity is to eliminate, to a large extent, the value of precedents, since it has been held that the fact that a combination of certain systems of a certain size has been permitted does not mean that all combinations of systems of an equal or lesser size will be permitted.

Another feature of Clause $\mathrm{C}$ to be noted is that almost identical language is included in the tests for integrated electric and gas utility systems set forth in Section 2(a)(29)(A) and Section 2(a) (29)(B) of the Act. It has been held that Clause $C$ should be applied in a manner similar to those sections, and consequently a study of Clause $\mathrm{C}$ is incomplete without examination of the size standards imposed upon single integrated systems. In the foregoing discussion of Clause $\mathrm{C}$, the attempt was made to correlate the leading

${ }^{300}$ The Commonwealth \& Southern Corporation, Release No. 7615 (August I, 1947), mimeo. page 24 . 
cases involving such standards without completely repeating the earlier discussion thereof.

The singular reference to "area or region" in Clause C has been held to be of considerable importance. Additional systems in another area or region, geographically speaking, from the principal system or from each other may not be retained in combination. This means that Clause $\mathrm{C}$ imposes a geographical limitation in addition to the geographical requirements of Clause $\mathrm{B}$. However, Clause $\mathrm{C}$ contemplates more factors in regard to size than merely area covered. The physical properties involved, the plant accounts, revenues, and income should all be considered under the size standards of Clause $\mathrm{C}$, though in numerous cases some of these factors appear to be ignored.

Of the three objectives of Clause $\mathrm{C}$, localized management, efficient operation, and effectiveness of regulation, the first has concerned the Commission most frequently. One of the principal objectives of the Act was to remove the absentee control over the operations of local public utilities, which existed during the period of the vast utility empires. It was felt that management at a remote place had little sympathy with the local problems of the individual utilities. The third objective, effective regulation, has been the next most important provision. In fact, the first and the third objectives are largely interrelated. The great resources of the utility empires were disproportionate to those of the local regulatory authorities or to those of the local customers who might be dissatisfied with their service. The pursuit of effective local regulation has not proceeded at an even pace, however, as evidenced by the narrow decision on this point in the Engineers Public Service Company case and the liberal decisions in the Middle West and Lone Star Gas Corporation cases, involving similar aggregations of regulatory authorities.

It has been said that compactness of holding company 
utility systems was one of the principal objectives of the Act and that systems additional to the principal system should be small in comparison with such principal system. Clause $\mathrm{C}$ provides the essential requirements for the attainment of these criteria. The Van Horn property of the Engineers Public Service Company western system and the Deming property of the Cities Service Power \& Light Company system in Colorado and New Mexico are good examples of such smaller properties retainable in addition to principal systems. On the other hand, in the case of Columbia Gas \& Electric Corporation, three large systems were held to constitute a principal system and additional systems retainable therewith. With regard to the requirement of compactness, the differences in the regions or areas involved in the western properties of Engineers Public Service Company, for instance, were emphasized by the Commission in denying retainability, whereas a much larger geographical expanse of properties in the same territory was held to constitute a single integrated utility system in the Middle West case. The lack of uniformity in the application of Clause $\mathrm{C}$ is therefore another factor preventing a statement of the precise limits of its application.

Finally, it should be noted that the liberal decisions of the Commission relative to the size requirements of the Act, those involving The Middle West Corporation, The Columbia Gas \& Electric Corporation, American Gas \& Electric Company, and The Commonwealth \& Southern Corporation, are all more recent than The North American Company, Engineers Public Service Company, and other decisions hewing to the restrictive interpretation of Clause $C$ and the related provisions of Section 2(a) (29). The liberal decisions began in I 944 and, generally speaking, have continued in unbroken line since that time. The explanation does not lie in any radical change in the membership of the Commission, 
since it has not changed rapidly until very recent years, and, in any event, four of the five Commissioners who decided the North American and Engineers cases also passed upon the Middle West case. Perhaps it may be said that time has healed the wounds which gave rise to the Act and that the Commission has accordingly mellowed its former strict construction of the size standards of the Act. 


\section{The Retention of Other Businesses}

THE integration provisions of the Act require the Commission to limit each holding company system to a 1 single integrated public utility system, "and to such other businesses as are reasonably incidental, or economically necessary or appropriate to the operations of such integrated public-utility system," and further specify that "The Commission may permit as reasonably incidental, or economically necessary or appropriate to the operations of one or more integrated public-utility systems the retention of an interest in any business (other than the business of a public-utility company as such) which the Commission shall find necessary or appropriate in the public interest or for the protection of investors or consumers and not detrimental to the proper functioning of such system or systems." ${ }^{391}$ The first quotation in the foregoing sentence is known as the first other businesses clause, and the latter quotation is known as the second other businesses clause. The earliest interpretation of these two clauses was that the Commission must permit the retention of other businesses, including investment interests in utilities which are not statutory subsidiaries of the system involved, which are found to be reasonably incidental, or economically necessary or appropriate to the operations of a retainable integrated public utility system, and that as to both investments in nonutilities and interests in nonutilities sufficient to create the statutory parent-subsidiary relationship, these requirements may be met if their retention is found to be necessary or appropriate in the public interest or for the protection of investors or consumers and not detrimental to the proper

${ }^{301}$ Section 1 I (b) ( 1 ) of the Act. 
functioning of such system or systems. ${ }^{392}$ The primary distinction in this instance was between nonutility subsidiaries and investments in nonsubsidiary utilities. ${ }^{393}$ There was also some confusion early in the history of the Act as to whether the gas operations of a company primarily engaged in business as an electric utility might be retained under the other businesses clauses of the Act. This question was answered in the negative. ${ }^{394}$ In another instance, the Commission definitely held that utility subsidiaries not forming a part of the principal system or of permissible additional systems could not be retained under the provisions of the other businesses clauses. ${ }^{395}$

In The North American Company case, the Commission took occasion to make a few general observations relative to the other businesses requirements of the Act. They were as follows:

"If it be recalled that the Commission may permit retention of an interest in a nonutility business as 'reasonably incidental, or economically necessary or appropriate' to the operations of an integrated public utility system or systems, when it finds retention of such interest to be 'necessary or appropriate in the public interest or for the

${ }^{992}$ The United Gas Improvement Company, Release No. 2500 (January 18 , I 94 I) 9 S.E.C. 52 (194I), and 9 S.E.C. 818 (194I). Cf., The United Light \& Power Company, Release No. 2820 (June I3, I941).

${ }^{323}$ Section $2(a)(8)$ of the Act defines the term "subsidiary" to mean "(A) any company ro per centum or more of the outstanding voting securities of which are directly or indirectly owned, controlled, or held with power to vote, by such holding company (or by a company that is a subsidiary company of such holding company by virtue of this clause or clause (B)), unless the Commission, as hereinafter provided, by order declares such company not to be a subsidiary company of such holding company; and (B) any person the management or policies of which the Commission, after notice and opportunity for hearing, determines to be subject to a controlling influence, directly or indirectly, by such holding company (either alone or pursuant to an arrangement or understanding with one or more other persons) so as to make it necessary or appropriate in the public interest or for the protection of investors or consumers that such person be subject to the obligations, duties, and liabilities imposed in this title upon subsidiary companies of holding companies."

${ }^{304}$ Virginia Electric \& Power Company, 9 S.E.C. 46 I (I 941 ).

${ }^{305}$ The United Gas Improvement Company, 9 S.E.C. 52 (I94I). 
protection of investors or consumers and not detrimental to the proper functioning' of such a system or systems; and if it be recalled that the phrase 'public interest' is used in connection with the policy of curing evils which result 'when the growth and extension of holding companies bears no relation to economy of management and operation or the integration and coordination of related operating properties' (Section I (b) (4)), it becomes apparent that the historical background of the joint control of a nonutility business with a utility business has little or no bearing on the permissibility of its retention in a public utility holding company system. Interests held for a long period do not, by reason of that fact alone, achieve any relation to 'economy of management and operation' or 'the integration and coordination of related operating properties.' Indeed, it is the very purpose of Section II (b) (I) to require the severance of those interests acquired in the course of the historical 'growth and extension' of a holding company which do not satisfy the policy of the Act." ${ }^{396}$ (Emphasis added)

Furthermore, the Commission stipulated that the substantiality and stability of income afforded by nonutility interests is not, by itself, a factor warranting their retention in a public utility holding company system, since substantial and stable income might be afforded by businesses having no imaginable relationship to the economy of management and operation of integrated public utility systems. Therefore, the fact that a nonutility business is profitable does not constitute one of the essential elements for its retainability under the other businesses clauses. The same is true of economies resulting from joint use of personnel. The rule laid down by the Commission in this regard, similar to the test under Clause A, was that "unless the nonutility business is such

${ }^{396}$ The North American Company, i I S.E.C. I 94, 2 I 8-2 I 9 ( I 942). 
that resulting economies are economies in the operation of an integrated utility system, or systems, the mere showing of economies is of little weight in determining whether the nonutility business may be retained." ${ }^{397}$

In the same North American case the company contended that many of its nonutility properties should be retainable for the reason that their disposition would be very difficult, and that losses would be incurred upon the sale thereof. There were two answers to these contentions. The first was that the alleged losses most likely occurred in the past but were merely not recognized because no sale was made, and the fact that losses might be recognized upon the sale of these properties after the issuance of an order of the Commission did not necessarily mean that the market values thereof dropped because of such order. The second answer was that if there should be no market at a reasonable price, then an extension of time in which to dispose of the properties might be granted under Section I I (c) of the Act.

Another general principle laid down in the North American case was that the other businesses tests are not to be applied to operations grossly out of proportion to the utility business with respect to which they are claimed to be retainable. In other words, the other businesses of an integrated system should be clearly subordinate in size and importance to the utility business. ${ }^{398}$

Again, in the North American case, the company insisted that it need show no affirmative public benefit resulting from the retention of certain nonutility interests, it being sufficient to show that retention of such interests was compatible with the public interest. The Commission rejected this test and in-

${ }^{397}$ The North American Company, i I S.E.C. 194, 219 (1942). Cf., American Water Works \& Electric Company, 2 S.E.C. 972 (1937).

${ }^{309}$ Cf., The North American Company, Release No. 8626 (November 4, I 948); Cities Service Company, I5 S.E.C. 962 (I 944); and Standard Oil Company (New Jersey), i 4 S.E.C. 342 (ig43). 


\section{PUBLIC UTILITY HOLDING COMPANIES}

sisted that the phrases "public interest" and "proper functioning" of an integrated system in the other businesses clauses required that the activities of public utility systems be limited to those related to economy of management and operation of the public utility system and the integration and coordination of related operating properties. ${ }^{399}$

The next occasion for a definitive interpretation of the other businesses clauses of the Act arose in the Engineers Public Service Company case. The company there contended that the second other businesses clause relates back to the first other businesses clause and sets out standards in accordance with which the incidental nature or economic appropriateness of a proposed other business must be measured. The Commission agreed that both clauses must be read together but insisted that the two provisions do not contain isolated standards. It was observed that they were a closely knit part of a statute which has a clearly expressed policy, and that they appear in a section of that statute which was designed to limit the operations of a holding company system to a single integrated public utility system and to reasonably incidental or economically necessary or appropriate nonutility businesses. Consequently, according to the Commission, the phrases "public interest," "protection of investors or consumers" and "detrimental to the proper functioning of such system" not only illuminate the meaning of "reasonably incidental or economically necessary or appropriate," but also derive content from their context in the section and the

${ }^{399}$ The North American Company, I I S.E.C. 194, 220 (1942). This and the foregoing interpretations of the other businesses clauses by the Commission were affirmed in The North American Company v. Securities \& Exchange Commission, I 33 F. (2d) 148 (C.C.A., 2d Cir., 1943). On writ of certiorari to the United States Supreme Court, that court, though deciding only the constitutional issues involved, stated that "other holdings may be retained only if their retention is related to the operations of the retained utility properties." North American Company v. Securities \& Exchange Commission, 327 U.S. 686, 697 (1946). Cf., The North American Company, Release No. ro320 (December 28,1950 ). 
statute. Furthermore, it was pointed out by the Commission that Congress did not say that "the Commission shall permit the retention of a business which it finds to be necessary or appropriate in the public interest or for the protection of investors or consumers and not detrimental to the proper functioning of such system or systems. ${ }^{\text {"40 }}$ Instead it required that the Commission examine such factors in determining whether a business was retainable as reasonably incidental or economically necessary or appropriate to the operations of an integrated utility system. Counsel for Engineers Public Service Company argued that the basic questions before the Commission at this point were whether the retention of the business was appropriate for the protection of investors, or whether it was appropriate in the public interest, or whether it was detrimental to the proper functioning of an integrated utility system. The Commission felt that the questions suggested by the company were relevant in arriving at the solution to the ultimate issue, but that they did not constitute the true tests for retention of such a business. Insead, the fundamental question proposed by the Commission was this: Having in mind the protection of investors, the public interest and the proper functioning of an integrated utility system, is the retention of a particular nonutility business reasonably incidental to or economically necessary or appropriate to the operations of a retainable utility system $?^{401}$

The legislative history of the Act was cited by the Commission in the Engineers case in support of the foregoing conclusions. It was noted that Section I I of the Senate bill provided for divestment-

"... to the extent that the Commission finds necessary or appropriate to limit the operations of the holding

${ }^{400}$ But see The United Gas Improvement Co. v. Securities \& Exchange Commission, 138 F. (2d) 101 (C.C.A., 3d Cir., 1943).

${ }^{401}$ Engineers Public Service Company, 12 S.E.C. 41, 46-47 (1942). 
company system ... to a single geographically and economically integrated public-utility system and such business as is reasonably incidental, or economically necessary or appropriate, to the operations of such system; the Commission may permit as reasonably incidental or economically necessary or appropriate to the operations of such system the retention of an interest in any business (other than the business of a public utility company as such) .... if the Commission finds (I) that such business is affected with a public interest and its rates or charges are regulated by law, and that the retention of such interest in such business is not detrimental to the proper functioning of a single geographically and economically integrated public utility system. . . ."402

The provisions empowering the Commission to include, among other businesses reasonably incidental or economically necessary or appropriate, those businesses affected with a public interest and regulated by law were changed by the socalled "Minton Amendment" in conference, where the language now set forth in Section I I (b) (r) was substituted for the more limited language in the Senate bill. The conclusion of the Commission in connection with this change in the bill was that it permitted the inclusion, among reasonably incidental or economically appropriate other businesses, of enterprises other than those affected with a public interest and whose rates or charges were regulated by law. It was observed that the mere fact that a business falls within this description, however, did not under the Senate bill, and more clearly does not under the Act as passed, render it ipso facto "reasonably incidental or economically necessary or appropriate" to the operations of an integrated utility system, and that in each case it was necessary to examine the character and operation of the specific business sought to be retained and

${ }^{402}$ Engineers Public Service Company, 12 S.E.C. 41,47 , footnote 5 (1942). 
its relationship to retainable utility operations, and to determine whether it is reasonably incidental or economically necessary or appropriate to the operation of the utility system to which it is sought to be appended. ${ }^{403}$

The test laid down by the Commission in the Engineers Public Service Company case relative to the retention of other businesses, which required a functional relationship between the operation of such other businesses and the operation of the utility system to be retained, was rejected by the United States Court of Appeals for the District of Columbia upon an appeal of the case. ${ }^{404}$ The court felt that Congress did not contemplate the result reached in the Engineers case, but intended, on the contrary, to forbid the divestment of other businesses not detrimental to the functioning of the principal system if retention would serve the interests of the general public or the interests of investors or consumers, irrespective of the functional relationship between such businesses and the principal system. The court stated its basic premise as follows:

". . . The purpose to eliminate the evils of holding company systems is expressed in the Act in unmistakable terms, but in the provisions of the compromise measure, worked out in the legislative process, it also clearly appears that Congress realized that it was dealing with existing corporate structures that had been operated under common control for a long time and could not be cut down to a single ideal system in every case without disastrous consequences to public and individual inter-

${ }^{103}$ Ibid.

${ }^{404}$ Engineers Public Service Company v. Securities \& Exchange Commission, 138 F. (2d) 936 (C.A.,D.C., 1943). The contrary decision in The North American Company case, 133 F. (2d) ${ }_{4} 8$ (C.C.A., 2 d Cir., 1943), was noted, but it was observed that in the case of American Water Works \& Electric Company, Inc., 2 S.E.C. 972, 983-985 (1937), the Commission permitted retention of numerous other businesses which had no functional relationship to the other companies in the retainable system. 
ests. The purpose to protect these interests is made abundantly clear by an examination of the legislative history of the Act.

$$
\text { * * * * * * * }
$$

"The general purposes of the Act will not be frustrated by this interpretation. The Commission has the power and duty to determine whether the interests of the public or investors or of consumers will be served by the retention of other businesses, and even if it so finds, it must nevertheless require the severance of the other businesses from the system if it further finds that the combination is detrimental to the proper functioning of the system. If all of these findings are favorable to the continuance of the combination, the practical advantages shown by experience to flow from joint operation may still be enjoyed."

The court in this case did not presume to decide what other businesses were retainable under its test, since such final determinations of fact lay within the jurisdiction of the Commission, but instructed the Commission to ascertain the relevant facts and apply them in the light of the court's interpretation of the other businesses clauses.

The decision of the Circuit Court of Appeals for the Third Circuit in The United Gas Improvement Company case was rendered contemporaneously with the decision of the Court of Appeals for the District of Columbia in the Engineers Public Service Company case, and obviously each of these opinions was completely independent of the other. ${ }^{406}$ In the UGI case the Commission had found that the company's interest in certain other companies which were not statutory public utility companies was not reasonably inci-

${ }^{405}$ Engineers Public Service Company v. Securities \& Exchange Commission, 138 F. (2d) 936, 947-948 (C.A.,D.C., 1 943).

${ }^{400}$ The United Gas Improvement Company v. Securities \& Exchange Commission, 138 F. (2d) 1010 (C.C.A., 3d Cir., 1943). 
dental, economically necessary or appropriate to the operations of any integrated public utility system retainable by UGI. UGI contended that such finding was not adequate, arguing that the provisions of the second other businesses clause required the Commission to find, as to businesses other than statutory public utilities, that the retention of such businesses was not necessary or appropriate in the public interest or for the protection of investors or consumers and detrimental to the proper functioning of the integrated system or systems. Briefly stated, the position of UGI was that the Commission had no power to compel the divestiture of a nonpublic-utility business from an integrated system unless it was affirmatively found that the retention of such property would be detrimental to the proper functioning of the holding company system in interstate commerce. This was, of course, the substance of the holding of the Court of Appeals in the Engineers Public Service Company case.

The court in the UGI case expressed the opinion that the word "may" occurring as the third word of the Minton Amendment, the second other businesses clause, should be construed to read "shall." "The court further stated its position as follows:

“. . . The Minton Amendment serves to define what 'other businesses' designated in the first sentence of Section I I (b) (I) are reasonably incidental, or economically necessary or appropriate to the operations of the integrated system. The standard is plain. We conclude that unless the Commission finds affirmatively that the other businesses which the utility holding company seeks to retain meet the requirements of the amendment, they are subject to divestiture. The burden is upon the holding company to show that the businesses to be retained

${ }^{402}$ To the same effect see Engineers Public Service Company v. Securities \& Exchange Commission, 138 F. (2d) 936, 947, footnote 2 (CA.,D.C., 1943). 
fall within the accepted categories. If the holding company fails to do this, such businesses must be divested when so ordered by the Commission. UGI has had full opportunity to make its proof in this respect. It has not done so. . . . It follows that UGI's contentions must fall. ${ }^{408}$

Thus there arose a divergence of opinion as to the interpretation of the other businesses clauses as between the Commission and the Circuit Courts of Appeals for the Second and Third Circuits in The North American Company and The United Gas Improvement Company cases, on the one hand, and the Court of Appeals for the District of Columbia in the Engineers Public Service Company case on the other hand. ${ }^{409}$ The Commission has subsequently proceeded on the assumption that the Supreme Court of the United States in The North American Company case approved its requirement of functional or operating relationship for other businesses by stating that "other holdings may be retained only if their retention is related to the operations of the retained utility properties. ${ }^{\mathbf{4 1 0}}$ Also, in a number of instances the Commission

${ }^{408}$ United Gas Improvement Company v. Securities \& Exchange Commission, 138 F. (2d) 1010, 1021, 1022 (C.C.A., 3d Cir., 1 943).

${ }^{409}$ In Arkansas Natural Gas Corporation $v$. Securities \& Exchange Commission, 154 F. (2d) 597, 599-600 (C.C.A., 5th Cir., 1946; cert. denied, 329 U.S. 738 ), it was noted that the Supreme Court had granted certiorari in both the North American and the Engineers cases, and therefore that neither case stood as a precedent. The view of the Fifth Circuit Court in this case was that "This sentence (the second other businesses clause) is not a redefining of the 'other businesses' previously mentioned as retainable, but is an enlargement, an addition thereto. In the first mention the operations of the utility system are in the foreground, and what is merely incidental to them, or what is economically necessary or appropriate to them may be retained. In the second mention of other businesses the public interests, and the protection of investors and consumers are in the foreground, and retentions necessary and appropriate to protect these are permissible additionally, if not detrimental to the proper functioning of the system." Id. at 599. Although this decision is not clear cut, apparently this court tended to favor the Second Circuit's interpretation of the other businesses clauses as set forth in the North American case.

410 The North American Company v. Securities \& Exchange Commission, 327 U.S. 686,697 (1946). Although writs of certiorari were granted to the 
has held that under either interpretation certain other businesses were not retainable. ${ }^{411}$

It may be observed further that, although the argument centered largely around the terminology of the other businesses clauses, the underlying philosophy of the Commission as to the Act as a whole was obviously tangential to that of the Court of Appeals. It has already been stated that the Commission did not believe that historical association constituted a valid reason for the retention of other businesses. In addition, the Court of Appeals of necessity imposed the requirement that the combination not be "detrimental to the proper functioning of the system as a whole." In view of the "intangible benefits" theory developed by the Commission under Clause $A$, which was to the effect that there were certain advantages arising from the separation of properties, such as electric and gas utilities, that could not be measured in terms of dollars but were substantial nevertheless, it would appear that if pressed on the point, the Commission would have applied a similar theory to the separation of other

Commission and the company in the Engineers Public Service Company case, 322 U.S. 723 ( 1944 ), decision of the case was delayed by the absence of a quorum and later the issue was rendered moot by the partial consummation of a plan under Section $\mathrm{II}(\mathrm{e})$ by the company. Consequently, the decision of the Court of Appeals was vacated and dismissed as moot, 332 U.S. 788 (1947). Securities \& Exchange Commission v. Central-Illinois Securities Corporation, 338 U.S. 96, Ior (1948), and In re Engineers Public Service Company, i68 F. (2d) 722, 725 (C.C.A., 3 d Cir., 1948). Cf., The North American Company, Release No. 10320 (December 28, 1950), mimeo. page 15 ; and Philadelphia Company, Release No. 8242 (June 1, 1948), affirmed in Philadelphia Company v. Securities \& Exchange Commission, 177' F. (2d) 720, 726 (C.A.,D.C., 1949). In the latter case the Court of Appeals for the District of Columbia indicated by way of dictum that the Supreme Court decision in The North American case was controlling on the question.

${ }^{411}$ Cf., Cities Service Company, 15 S.E.C. 962 (1 944 ), affirmed as to part of the properties in question in Arkansas Natural Gas Corporation v. Securities \& Exchange Commission, 154 F. (2d) 597 (C.C.A., 5th Cir., 1946; cert. denied, 329 U.S. 738); The Middle West Corporation, 18 S.E.C. 296 (1945); Philadelphia Company, Release No. 8242 (June 1,1948 ), affirmed in Philadelphia Company v. Securities \& Exchange Commission, 177 F. (2d) 720 (C.A.,D.C., r949). 
businesses. Consequently, if obliged to follow the rule of the Court of Appeals, the Commission might well have said the intangible benefits resulting from the disposition of many other businesses were so great that the retention of such businesses would be "detrimental to the proper functioning of the system as a whole." Thus the end result would likely have been the same under either approach. ${ }^{412}$

One of the reasons given most frequently in justification of the retention of other businesses is the joint use of personnel and facilities between the other businesses and the integrated utility system. The Commission has taken the position that unless the economies arising from such joint use of personnel and facilities are economies in the operation of the integrated

${ }^{412}$ An indication of this may be found in Philadelphia Company, Release No. 8242 (June I, I 948), at mimeo. pages 47-48, where the Commission used this language: "In weighing considerations affecting the public interest and the interests of investors and consumers, we cannot overlook the possibilities inherent in common control of properties of such a character that transactions between them and the conduct of their operations may be influenced to favor one property rather than another and the consequent potentialities for substantial detriment to investors, consumers and the general public. It has been suggested, for example, that Philadelphia Company's control of Pittsburgh Railways may have impeded or will impede the natural growth of motor bus service in order to maintain and foster Duquesne's electricity revenues from the electric street railways, and that there may have been or will be overreaching in the fixing of the rates charged Pittsburgh Railways for power. We do not mean to intimate that the evidence in the present record proves that such overreaching has in fact taken place. It is enough to point out here the potentialities for such overreaching while the properties remain under common control. We think these factors must be given due consideration in determining whether a showing has been made that common control of the utility and transportation systems is affirmatively in the public interest or for the protection of investors or consumers." See, also, The Middle West Corporation, is S.E.C. 296, 301 (r 945 ), where the Commission stated that "Whether this last sentence (of Section II(b) ( I)) be regarded as setting the framework within which to interpret the standards 'reasonably incidental or economically necessary or appropriate' (See North American Company v. S.E.C., I 33 F. (2d) $148 \ldots$..) or be read as a substitute for those standards (See Engineers Public Service Company v. S.E.C., 138 F. (2d) $936 \ldots$ ) the sentence cannot be torn from its context in the Act. The express policy of the Act in this respect is to permit retention only when necessary for "economy of management and operation or the integration and coordination of related operating properties.' (Section I (b) (4), emphasis supplied)" Cf., Texas Utilities Company, Release No. 6373 (January I 7, I 946). 
system, they have little bearing upon the question. ${ }^{413}$ The attitude of the Commission is that the fact that a completely unrelated enterprise enjoys certain advantages from its connection with a utility business is irrelevant in determining whether the nonutility business is "reasonably incidental, or economically necessary or appropriate" to the utility business. But conversely, some advantages in common use of personnel may be found resulting to utility operations from their connections with even the most unrelated types of properties.

It is well settled that the burden is upon the holding company to show that the "other businesses" sought to be retained meet the standards of the Act. ${ }^{414}$ The disposition of other businesses may be ordered even though the location of the principal system has not been finally determined, where it appears that such businesses could not meet the statutory tests as to any possible combination of retainable properties. ${ }^{415}$ In spite of the fact that both counsel for the

${ }^{418}$ Cities Service Power \& Light Company, 14 S.E.C. 28 (1943). In The Middle West Corporation, I 8 S.E.C. 296, $301-302$ (1945), the principle was stated as follows: "The sharing of personnel as between utility and nonutility, the servicing of the same customers by both, the provision of electricity by the utility to the nonutility and difficulty in disposition of the nonutility are factors which may exist no matter how unrelated the nonutility business may be. By themselves these factors do not warrant a finding of retainability in the light of the policy of the Act. When combined with other factors which show a relation to the management of an electric utility business-as a functioning unit rather than as a revenue producing vehicle-these considerations may be given weight. But to lose sight of the essential requirement of operating relationships is to depart from the basic policy of the statute. The standards of 'public interest,' 'protection' of investors and consumers, the 'proper' functioning of utility systems do not exist in a vacuum. They are parts of an Act whose critical function is to simplify the operations and structures of holding company systems. These standards, when viewed in their statutory context, cannot be read to permit the retention of properties which have no relation to the operation of the utility business." Cf., The Commonwealth \& Southern Corporation, Release No. 76 I 5 (August I, I 947 ).

${ }^{414}$ Philadelphia Company, Release No. 8242 (June I, 1948), affrmed in Philadelphia Company v. Securities \& Exchange Commission, r 77 F. (2d) 720 (C.A.,D.C., I 949); and The United Gas Improvement Company, I 38 F. (2d) I о о (C.C.A., 3 d Cir., I 943 ).

${ }^{415}$ The United Gas Improvement Company, 9 S.E.C. 8 I 8 (I94I). 
Public Utilities Division of the Commission and counsel for the company involved have agreed that certain other businesses should be divested, the Commission must pass judgment upon each one individually under the Act. ${ }^{416}$ One of the reasons for this is that certain tax benefits are available where disposition of properties is ordered pursuant to the Act. ${ }^{417}$ On the other hand, where counsel for the Public Utilities Division agreed with company counsel that certain other businesses were retainable, but the Commission was of a contrary opinion, the case was reopened to allow the company to present a full record upon a claim of surprise by the company. ${ }^{418}$

The foregoing observations give the general background for the application of the other businesses clauses. Set forth below are discussions of the principal specific types of incidental businesses which have been presented to the Commission and to the courts for approval.

\section{INVESTMENTS}

The term "investment" as used under this subheading refers to the ownership of an interest in a statutory utility or a nonutility company not sufficient to make such company a subsidiary of the public utility holding company as provided in Section 2(a) (8) of the Act. The reference is not to subsidiaries engaged in the investment business, another type of incidental business. ${ }^{419}$ It has been held that utility subsidiaries

${ }^{416}$ Cities Service Power \& Light Company, I 4 S.E.C. 28 (1943).

${ }^{417} \mathrm{Cf}$., Sections I I 2 (b) (8), 37 I and I 808 of the Internal Revenue Code of the United States.

${ }^{418}$ Cities Service Power \& Light Company, I4 S.E.C. 233 (I 943).

${ }^{410}$ Such subsidiaries have generally been held not to be retainable under the other businesses clauses. The main argument for their retention has been that they contribute "diversity" to the holding company system. The Commission has noted that the argument that mere diversity of investment justified the retention of an unlimited number of varied interests was presented at length to Congress at the time the holding company act was under consideration and concluded that Congress clearly indicated its rejection of this argument. The North 
cannot be retained under the provisions of either of the other businesses clauses. ${ }^{420}$ The second clause, of course, specifically excludes the business of a public utility company as such, and the Commission observed that it was the intention of Congress to require that utility subsidiaries, if they were to be retained, must be fitted into the single integrated system or any additional systems meeting the standards of the $A B C$ clauses. In the UGI case, the holding company owned an interest in certain Connecticut utility properties which fell within the statutory definition of subsidiaries. However, the company contended that the Connecticut properties should not be so considered because of a Connecticut statute prohibiting the control of Connecticut utilities by a foreign holding company. In other words, the company contended that the Connecticut properties constituted investments rather than subsidiaries. The Commission held that the Connecticut properties were utility subsidiaries within the meaning of Section 2(a) (8) of the Act and that therefore, upon the basis of the rule set forth above, they were not retainable under the other businesses clauses. ${ }^{421}$

In one of the first cases interpreting the Act, the Commission indicated that the other businesses clauses permitted the retention of investment interests in utility properties which were not subsidiaries of the holding company. ${ }^{422}$ This led company counsel to take the position that investment interests of holding companies, i.e., interests insufficient to create the statutory parent-subsidiary relationship, in both utilities and nonutilities were beyond the scope of any of the provisions of Section II (b) (I) and that no order could issue under that

American Company, I I S.E.C. I 94 (1942). Cf., Columbia Gas \& Electric Corporation, 17 S.E.C. 494 (1 944 ).

${ }^{420}$ The United Gas Improvement Company, 9 S.E.C. 52 (I 941 ).

${ }^{221}$ I bid.

62 The United Gas Improvement Company, Release No. 2500 (January i 8, $1941)$. 


\section{PUBLIC UTILITY HOLDING COMPANIES}

section requiring the divestment of such investment interests. The argument was that Section I I (b) ( I ) referred to "operations" of holding company systems, that nonsubsidiary interests were not "operations," and consequently that the provisions of Section I $\mathrm{r}$ (b) ( I) did not affect them. It was further argued that both of the other businesses clauses referred only to nonutility interests which were "operated," which was interpreted to mean only interests which were subsidiaries. The Commission rejected this construction of the Act. ${ }^{423}$ The first reason given was that by the very nature of a holding company its operations consisted largely of the mere holding of securities in other businesses, the investment of funds being a necessary and important part of its business. It was observed that such investment function, even when it did not result in control by the holding company of the companies in which the funds were invested, was just as surely a part of the operations of the holding company and of the holding company system as were its other activities. Another reason propounded by the Commission was that the terminology of Section 9, Section I0, and Section I I (a) of the Act left little doubt that Congress intended that the provisions of Section I I (b) ( I) should cover both controlled properties and other interests of the holding company. This decision was affirmed on appeal, where the court stated the case as follows:

". . . But UGI makes the contention that no power was conferred upon the Commission to compel divestiture of any interest which a holding company may have in a statutory public utility which it does not operate; that is to say, which is not a subsidiary of the holding company. UGI contends that significant words lie in the first sentence of Section I I (b) (I) which provides that the Commission shall take such action as may be appropriate $* * *$ to limit the operations of the holding-

${ }^{423}$ The United Gas Improvement Company, 9 S.E.C. 52 (1941). 
company system ***? If an investment in a company is not such an interest as will permit the holding company to operate the company of which the interest is held, then, says UGI, the Commission has no power to limit the holding company system by compelling the holding company to divest itself of its interest or investment in such a company. UGI takes the position that the stated purpose of the Act as contained in Section I (a) ... and the abuses sought to be corrected as set out in Section I (b) ... demonstrate that it was the intention of Congress to so limit the power of the Commission.

"While control by a holding company of a subsidiary generally connotes management or at least some measure of supervision, this is not always the case. It is always true however, that the functioning of a holding company includes the holding of stocks of other companies. In every case the 'operations' of a holding company consist largely of holding stocks. The word 'operation' in its commonest usage means simply the ${ }^{* * * *}$ act, process, or effect of operations' (citing Webster's New International Dictionary, Second Edition) and there is nothing in the Act or in its history which would lead us to conclude that Congress intended another or different meaning for this word. . . . We think that Congress did not intend the strained construction which UGI seeks to put upon the statute. The obvious intention of Congress in enacting Section II(b)(I) was to integrate public utility holding company systems and to compel holding companies subject to the Act to relinquish interests in unrelated utilities as well as unrelated non-utility companies. The myriad, promiscuous activities and investments of some of the holding company systems was (sic) a prime cause of investors' losses.

"That the jurisdiction of the Commission to limit holding company systems goes as far as we have indi- 
cated is made plain by an examination of Section I I (a), ... of the last sentence of Section I I (b) (I) and Sections $9(\mathrm{a})$ and IO...."324

In the proceedings involving the Engineers Public Service Company it was contended by the holding company that the Commission's order of divestment relative to properties found to violate the standards of Section I I (b) (I) should go no further than to require the company to divest itself of control over such properties, and should not require the company to divest itself of all interest therein. The argument was that, even though Section I I (b) (I) prohibited the company from operating or controlling the non-conforming utility systems and other businesses, its provisions would permit the company to retain an investment interest therein. The Commission rejected this proposition, holding that the reduction of ownership to less than Io\%, thereby formally falling outside of the provisions of Section $2(a)$ (8) defining subsidiaries, and the retention of such property as an investment could not be allowed. ${ }^{425}$ In the first place, the Commission felt that an investment interest in a company which had been dominated, controlled, and serviced by the holding company for a number of years as in this case was substantially different from the ownership over a period of years of an investment interest in a non-affiliated company, as in the UGI case discussed immediately above. The Commission doubted that the proposed procedure would effectively eliminate the controlling influences of the holding company. In the second place, the Com-

\footnotetext{
${ }^{424}$ The United Gas Improvement Company v. Securities \& Exchange Commission, 1 38 F. (2d) 1 010, 1018-1019 (C.C.A., 3d Cir., 1943). Investment interests of The United Gas Improvement Company in two gas utilities were ordered divested. In The United Light \& Power Company, 9 S.E.C. 833 (I 94 I), the retention of the investment of American Light \& Traction Company in the stock of Detroit Edison Company, an electric utility, was not permitted. See, also, The United Gas Improvement Company, Release No. 10624 (June I5, $195 \mathrm{I}$ ).

${ }^{125}$ Engineers Public Service Company, 9 S.E.C. 764 (I94I).
} 
mission was of the opinion that the provisions of Section $2(a)(8)$ were not designed as a means of obstructing and delaying integration proceedings and reasoned that Congress could not be thought to have intended any such inconclusive disposition of questions under Section I I (b) ( 1 ), which calls not only for finality of action but also for promptness of action which would be precluded by the injection of Section $2(\mathrm{a})(8)$ proceedings wherever divestment of the securities of a subsidiary was involved.

It will be recalled that the second other businesses clause specifically excludes from consideration thereunder the business of a public utility. By virtue of the overlapping language of the two other businesses clauses the Commission has held as indicated above, that the two clauses must be read together and that the factors listed in the second clause should be examined in all cases. The Commission has gone one step further and considered whether the exclusion of public utility businesses in the second clause should also be applied to the first clause, thereby preventing entirely the retention of interests in non-subsidiary utilities as other businesses. Although the question was not decided, the Commission stated that such conclusion had much to support it. ${ }^{426}$ It was noted that the provisions of Section IO (c) (2) indicated that such a construction of the other businesses clauses was proper. Under the latter section, an investment interest in a non-subsidiary utility property could not be acquired by a holding company in the absence of an affirmative showing that such acquisition would serve the public interest by tending towards the economic or efficient development of an integrated public utility system. No subsequent case has been found, however, in which the issue as to non-subsidiary utility investments has been raised. The exact meaning of the Act in this situation is

\footnotetext{
${ }^{423}$ Engineers Public Service Company, 12 S.E.C. 4I (1942), and The United Gas Improvement Company, ix S.E.C. $33^{8}$ (I 942 ).
} 


\section{0 PUBLIC UTILITY HOLDING COMPANIES}

very obscure, but in view of the early stand of the Commission to the effect that it was possible to retain such investments as other businesses, provided that they met the other tests of retainability, it is quite likely that such precedent will not be altered.

\section{COAL}

The Commission at an early date held that a coal business bearing an intimate relationship to the operations of the permissible utility system was retainable. ${ }^{\mathbf{4 2 7}}$

In The North American Company case it appeared that one of its subsidiaries, Union Colliery Company, operated coal mines in Illinois, 85 miles southeast of St. Louis, which supplied most of the coal used by the electric properties of the system in and around St. Louis. Over $80 \%$ of the output of these mines was used by the St. Louis (Union) group for generating electricity. These mines were shown to be a convenient and economical source of a commodity vital to the utility operations of the system. The economies resulting from joint operaton of the coal company and the Union group were related to the economic and efficient management of the electric utility system. Furthermore, the coal company was wholly owned by Union Electric Company of Missouri, the owner of the principal system, and appeared to be operated as a mere department of the Union group. For these reasons the Commission held that the business of Union Colliery Company was retainable by the Union Group and by North American as an incidental business. ${ }^{48}$

On the other hand, the Commission held that the coal mining business operated by West Kentucky Coal Company, a North American subsidiary, was not retainable. ${ }^{429}$ The coal

\footnotetext{
${ }^{427}$ American Water Works \& Electric Company, 2 S.E.C. 972 (1937).

${ }^{428}$ The North American Company, I I S.E.C. 194 at 225-226 (1942).

${ }^{429} I d$. at 223-224.
} 
output of this company during 1940 and prior years had been sold almost exclusively to nonaffliated purchasers. The reason given in support of the retainability of this property was that the company's mines would afford a source of supply for the Union electric operations of North American if other sources were closed off. There was no evidence that such contingency had occurred in the 35 years of the coal company's existence. It therefore appeared that the stock of this company represented merely an investment in a business which bore no relation to the permissible utility operations.

North American refused to capitulate in the matter of the properties of the West Kentucky Coal Company. Six years later it approached the Commission with an offer to prove that the electric energy demand of Union had increased by $65 \%$ since 1940 and that the existing demand would be almost doubled by 1962 ; that this increase in demand for electric power caused a corresponding increase in the coal requirements of Union; that although Union obtained only $35 \%$ of its coal from outside sources in 1940 , it then purchased $77 \%$ from such sources: that West Kentucky had developed new processes which made available a superior type of generating fuel; that additional mines of the special type of coal preferred by Union could be developed if firm commitments for future years were secured from Union; and that annual savings of $\$ 2,000,000$ would result from the combination of properties. The Commission pointed out that in 1947 Union obtained only $15 \%$ of its coal from West Kentucky, and that West Kentucky only sold $8 \%$ of its output to Union. North American contended, however, that the Commission should go beyond the then existing relationship and consider its estimates of future operations of Union and West Kentucky; that in I962 it was probable that Union would obtain $56 \%$ of its coal from West Kentucky, which would equal $42 \%$ of the latter's production in 1947 . It was 


\section{$25^{2}$ PUBLIC UTILITY HOLDING COMPANIES}

noted, further, by the Commission that West Kentucky had grown in the intervening years so that in 1947 it was the eighteenth largest bituminous coal producer in the country and its net income was approximately one-third the consolidated net income of Union. The Commission indicated that in determining the retainability of nonutility properties as incidental businesses, primary emphasis should be given to presently existing facts rather than to estimates for many years in the future, but it did give consideration to the prospective plans of Union. The relative size of West Kentucky was also taken into consideration, and it was observed that the company was a substantial industrial enterprise, well able to stand by itself, whose only relation to the electric utility business was that of a normal commercial supplier. And since the major function of West Kentucky, even pursuant to the future projections of North American, was its outside sales, the Commission felt that its coal business was not and would not be devoted primarily to furthering the operations of Union, but would be essentially devoted to independent ends. Consequently, it was held that the change of conditions since I 940 was not an adequate basis upon which to predicate a modification of the earlier divestment order. ${ }^{430}$

Nothing daunted, North American returned to the fray with a proposition to segregate the Sturgis Division coal properties of West Kentucky, the properties which produced the coal desired by Union, from the other properties of the company and to retain only the former. It was contemplated that by 1953 all of the Sturgis Division coal production would be used in the operation of Union's electric system. In spite of the fact that much of the record was based upon conjecture and estimates for the future, the Commission noted that the electric utility system of Union would remain subject to its jurisdiction and therefore could be reexamined in the light

4:30 The North American Company, Release No. 8626 (November 4, I 948 ). 
of future developments. It was held that the Sturgis Division coal properties were retainable and the plan of North American was approved. ${ }^{41}$

In another case it appeared that all of the coal produced by a coal company and an associated mining company was used by a generating station of the parent electric utility system, except for incidental sales to employees. In normal years all of the coal used by the particular generating station came from this source. Retention of these other businesses was permitted. ${ }^{432}$

\section{Production and Transmission of Gas}

In many natural gas utility systems the facilities include not only distribution lines but also production and transmission properties. The question has arisen whether the latter properties may constitute part of the integrated utility system or whether they may be retained, if at all, under the terms of the other businesses clauses of the Act. ${ }^{433}$ It has been held, for example, that production and transmission properties may be retained either as part of the integrated system or as other businesses. ${ }^{434}$ The issue was raised in the appeal of Arkansas Natural Gas Corporation, a subsidiary of Cities Service Company, and the Circuit Court of Appeals for the Fifth Circuit decided that the production and transmission of natural gas was not part of the integrated system but could be retained as other businesses. ${ }^{435}$

${ }^{431}$ The North American Company, Release No. 9190 (June 24, 1949).

${ }^{482}$ American Gas \& Electric Company, Release No. 6333 (December 26, 1945). Also see Ohio Power Company, Release No. 7031 (November 27, I 946); Ohio Power Company, Release No. 8079 (March 25, 1948); Appalachian Electric Power Company, Release No. 8I73 (April 30, I948); and Appalachian Electric Power Company, Release No. 8285 (June I 8, I 948). The most recent decision to the same effect is General Public Utilities Corporation, Release No. 10982 (December 28, I95 I).

${ }_{433}$ Cities Service Company, 15 S.E.C. 962 ( 1944 ).

${ }^{434}$ Ibid. and The Middle West Corporation, I 5 S.E.C. 309 (1944).

${ }^{425}$ Arkansas Natural Gas Corporation v. Securities \& Exchange Commission, 154 F. (2d) 597 (C.C.A., 5th Cir., 1946; cert. denied, 329 U.S. 738 ). 
In the Lone Star Gas Corporation case, it appeared that the natural gas production operations of this gas utility system were substantially subordinate in size to the utility operations of the retainable system. Approximately $30 \%$ of the system's natural gas requirements was produced by these properties. The gas fields owned by the company were all located within or adjacent to the system area. The gas transmission operations of the system were approximately equal in size to the utility operations. Its pipe lines transmitted all of the requirements of its distribution properties, and with a minor exception the company itself distributed all of the gas which it produced and transmitted. There existed close operating coordination between the production, transmission, and distribution operations to assure that the production and transmission facilities would be adequate to meet the varying distribution demands. The three operations were essentially limited to the State of Texas. It was held by the Commission that the gas production and transmission operations of the Lone Star system were retainable under the other businesses clauses. $^{436}$

In The North American Company case one of its natural gas utility subsidiaries, Northern Natural Gas Company, sought to retain its production and transmission properties, which extended from Texas to Minnesota, along with its distribution system in Nebraska, Iowa, Minnesota, North Dakota, and South Dakota. In contrast to the Lone Star situation, the great bulk of Northern's assets was represented by its production and transmission properties. The Commission observed that, generally speaking, the other businesses clauses should not be applied to operations grossly out of proportion to the utility business with respect to which they were claimed to be reasonably incidental, or economically

${ }^{466}$ Lone Star Gas Corporation, I 2 S.E.C. 286 (1 942 ). 
necessary or appropriate, and that the utility function should constitute the primary business of a system with retainable nonutility interests occupying a clearly subordinate position thereto. Nevertheless, an exception to such rule was made in this case because of the nature of the natural gas utility industry in general and the problems of this system in particular. The pipe lines of the system supplied all of the gas distributed by it and were vital to its operations. The joint ownership of these facilities was found to be in compliance with the other businesses clauses. ${ }^{437}$

In a later decision the transmission lines of another North American and Northern Natural subsidiary, Argus Natural Gas Company, were held to be retainable as other businesses in combination with the properties described above. ${ }^{438}$ The gas transmission and distribution facilities of Argus had previously been held nonretainable as an additional system to Northern. However, it was shown that the transmission system of Argus in Kansas was essential to the gas utility operations of Northern, because such system constituted the means by which Northern might secure gas from another field, it appearing that the gas supply of the field then being used by Northern was diminishing while the demand was rapidly rising. Among the industrial consumers of Northern were several concerns engaged in important war work. It was felt that the wartime building restrictions would prevent the construction of new gas transmission lines where presently existing facilities, such as those of Argus, were available. Northern was also depending upon the transmission lines of Argus in an increasing degree for the transmission of gas from Northern's gas leaseholds to its own pipe lines. Therefore, these lines of Argus formed a logical part of the retainable pipe lines of Northern.

${ }^{47}$ The North American Company, i I S.E.C. I 94 ( 1942 ).

${ }^{438}$ The North American Company, i 3 S.E.C. 98 ( 1943 ). 


\section{PUBLIC UTILITY HOLDING COMPANIES}

The gas utility systems of the Columbia Gas \& Electric Corporation presented a different picture. Panhandle Eastern Pipe Line Company was a subsidiary of Columbia engaged in the business of producing, purchasing, transmitting, and selling natural gas. At the time in question it obtained its gas from Texas, Oklahoma, and Kansas, and its pipe lines extended through those states and Missouri and Illinois. Subsidiaries of Panhandle Eastern also served areas in Indiana, Ohio, and Michigan. There were no connections between the lines of Panhandle Eastern and its subsidiaries and those of any other company in the Columbia system, except for a connection in Ohio. This connection was separated by a valve which was usually closed, and the interchange of gas at this point was negligible. Panhandle and its subsidiaries bought no other gas from, sold no gas to, and had no operating relationship with any other company in the Columbia system. Furthermore, the entire capacity of Panhandle was required for its own customers. All parties agreed, and the Commission held, that the nonutility properties of Panhandle Eastern and its subsidiaries were not retainable as other businesses in connection with any of the gas utility systems of Columbia. ${ }^{439}$

In the Cities Service Company gas utility system in the Mid-Continent area, gas was supplied by Cities Service Gas Company, a subsidiary of Cities. This gas company produced and transported natural gas, its pipe lines being located in Texas, Oklahoma, Kansas, Missouri, and Nebraska. It produced about one-half of the gas which it supplied through its pipe lines. There was complete coordination between the gas company and the three distributing companies, all Cities subsidiaries, which it supplied. A private telephone system owned

${ }^{439}$ Columbia Gas \& Electric Corporation, i I S.E.C. 80 ( I942). The closely coordinated gas production and transmission facilities operated in connection with the retainable gas utility systems met the tests of the other business clauses, however. Columbia Gas \& Electric Corporation, i 7 S.E.C. 494 (1944). 
by the gas company connected it with all of the distribution systems, and the dispatching office of the gas company operated on a 24-hour basis in order to keep in touch with the requirements of all of the distributing outlets and with every source of supply. Ninety-seven per cent of the gas distributed by the utility companies was furnished by the gas company, and the latter's lines connected the many separated distribution systems. It thus appeared that this combination of properties operated as a synchronized whole, and that the production and transmission assets were properly retainable as other businesses. ${ }^{440}$ Cities Service Company also sought to retain two other subsidiaries in connection with Cities Service Gas Company. These were Texoma Natural Gas Company, a gas producing company, and Natural Gas Pipe Line Company of America, a transmission and wholesale distribution system. Practically all of the gas produced by Texoma was sold to Natural, and this was $75 \%$ of the requirements of Natural. Natural sold its gas to nonsystem companies in Iowa and Illinois. The pipe line of Natural extended 900 miles from Texas into Oklahoma, Kansas, Illinois, Iowa, and Nebraska. In Kansas it crossed the lines of Cities Service Gas Company. Natural and the latter company had contracted for emergency purchases of gas by Cities Service Gas from Natural. Several times, when breaks had occurred in its own lines, Cities Service Gas had exercised its right to purchase gas from Natural. And between Texoma and Cities Service Gas there was a contract providing for the exchange of natural gas in the field when, on occasion, the production of one company might more conveniently be gathered by the other. The Commission thought that such connecting relationships were too remote and were operationally infrequent and insignificant. Further, such contractual relations did not depend upon the existence or con-

${ }^{440}$ Cities Service Company, 15 S.E.C. 962 ( 944 ). 


\section{$25^{8}$ PUBLIC UTILITY HOLDING COMPANIES}

tinuation of common control but could well exist under separate ownership. Divestment of Natural and Texoma was ordered. $^{441}$

A novel situation arose in connection with the gas utility system of American Light \& Traction Company, a subsidiary of The United Light \& Railways Company. American organized a corporation, Michigan-Wisconsin Pipe Line Company, for the purpose of constructing and operating a natural gas pipe line extending from Texas to Michigan and Wisconsin. It had organized another corporation, Austin Field Pipe Line Company, for the purpose of constructing a pipe line from the Austin storage field in central Michigan to Detroit and other points. The purpose of these pipe lines was twofold: to provide an adequate supply of gas, and to unite and interconnect the scattered units of the American gas properties into an integrated system. ${ }^{42}$ Thus the question was presented for the first time whether nonutility properties not yet constructed might be held to meet the requirements of the other businesses clauses. The Commission believed that the operations of these two pipe line companies were intimately related to the utility properties which would be retainable by American upon completion of the pipe lines. It was noted that the pipe lines were the integrating factor which would permit coordinated operation of the properties and which would bring about substantial economies in the system. The conclusion was that the pipe line companies were retainable as other businesses. ${ }^{43}$

Panhandle Eastern Pipe Line Company, the principal gas supplier of American at that time and a non-affiliated company, vigorously attacked this finding in an appeal of the

${ }^{441}$ Ibid.

${ }^{442}$ The gas distribution properties of the American Light \& Traction Company system were located in southeastern Wisconsin and central and southern Michigan, the principal cities served being Milwaukee and Madison, Wisconsin, and Detroit and Grand Rapids, Michigan.

${ }^{443}$ The United Light \& Railways Company, Release No. 7951 (December 30, 1947 ). 
case to the United States Court of Appeals for the Eighth Circuit. It contended that the Commission was without power or authority to anticipate the construction of the two pipe lines in determining whether an integrated system would exist and was required to deal with the holding company system as it then existed, not as it might appear at some future time after the construction of the pipe lines. Panhandle Eastern also contended that the Commission had not specifically found that the non-utility properties of American were necessary or appropriate in the public interest or for the protection of investors or consumers and not detrimental to the proper functioning of the integrated utility system, as required by the second other businesses clause. The court answered the first argument by stating that the pipe line project was not so illusory at the date of the Commission's decision that the Commission could not consider its construction in determining the propriety of American's proposed plan of compliance with Section II (b) (I), and replied to the second argument by finding that the Commission had set forth factual determinations more than adequate to meet the requirements of the other businesses clauses, thereby affirming the Commission's order. $^{444}$

Other decisions favorable to the retention of gas production and transmission properties are set forth in the footnote below. ${ }^{45}$ In the usual case it appears that the retainable gas utility system is so closely intertwined operationally with the

${ }^{144}$ Panhandle Eastern Pipe Line Company v. Securities \& Exchange Commission, I 70 F. (2d) 453 (C.C.A., 8th Cir., 1948).

${ }^{445}$ The Mission Oil Company, Release No. 10969 (December 21, 1951) (natural gas production and transmission and gasoline extraction for gas utility system); Philadelphia Company, Release No. 8242 (June 1, 1948) (natural gas production for gas utility system) ; The Middle West Corporation, I 5 S.E.C. 309 (1944) (production and transmission of natural gas for use as generator fuel in electric utility system) ; Community Gas \& Power Company, I 3 S.E.C. 532 (r 943) (purchasing and reforming of natual gas and manufacturing of artificial gas for gas utility system); and Southern Union Gas Company, i 2 S.E.C. I 6 (1942) (production of natural gas for gas utility system). 
production and transmission properties which serve it that an order of divestment of such properties is a rarity.

\section{Production and Sale of Petroleum Products}

A number of holding company systems were engaged in the production, processing, and sale of various petroleum products, such as oil, gasoline, butane gas, and propane gas. Particularly was this true of the companies just discussed which were engaged in the production of natural gas. Natural gas, gasoline, and oil may all be produced by the same well, and if not by the same well they are all usually found in the same field. Exploration cannot be limited to one of these commodities, and a natural gas distributing company which seeks to establish its own sources of supply by drilling operations will almost invariably find itself in the oil business also if gas is located. The tail may wag the dog, however, and in a few instances it has appeared that the gas utility business of a holding company was minor compared to its petroleum business. A leading example of this was Standard Oil Company of New Jersey. Standard owned four natural gas utility subsidiaries, but its principal business consisted of owning securities in corporations engaged in the production, refining, transporting, buying, and selling of petroleum and petroleum products. Standard conceded and the Commission found that its petroleum business was not incidental to its gas utility business, and separation was ordered. ${ }^{446}$

Cities Service Company was in a similar position but refused to capitulate so readily. Cities Service Oil Company controlled a vast oil business involving the production, refining, transmission, and marketing of petroleum products in 45 states, Canada, and Mexico. The petroleum business was widespread, but it was operated as a unit in a coordinated

${ }^{446}$ Standard Oil Company (New Jersey), ${ }_{4}$ S.E.C. 342 (1943). 
manner. It was shown that the production of oil and natural gas were closely related, as indicated above; that the three largest gas fields were the result of exploration by oil companies; that the exploratory activities of oil companies were of the highest importance to gas companies; and that, therefore, it was a great advantage to a gas company to be affiliated with a large oil company which conducted exploratory activities in the general area of the gas company's property. The Commission commented, however, that the operational relation between the oil and gas businesses existed only in the gas production and conditioning phases, and not directly at any other point, and further, that the oil business must be related to the retainable utility properties, not merely to the nonutility gas production facilities, in order to be retainable. It was noted by the Commission that the vastness and complexity of Cities' oil business exceeded those of any other nonutility business ever presented to it for consideration under the other businesses clauses. The assets of the oil business of Cities were shown to be approximately twelve times as large as those of the gas distributing properties. Under any construction of the meaning of the other businesses clause, the Commission decided that the oil business of Cities was not retainable with the gas utility operations. ${ }^{47}$

On the other hand, in the Lone Star Gas Corporation case, the gasoline production operations of the system were clearly subordinate in size to the gas utility operations and bore a close relationship to the natural gas production operations. Such gasoline operations were confined to the extraction of natural gasoline from natural gas, a process necessary to

${ }^{4+1}$ Cities Service Company, 15 S.E.C. 962 (1944). The same ruling was applied to another subsidiary of Cities Service Company, Arkansas Fuel Oil Company, in this case. This decision was affirmed in the case of Arkansas Natural Gas Corporation v. Securities \& Exchange Commission, I54 F. (2d)

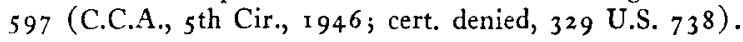


prepare the gas for distribution to the ultimate consumer. The Commission regarded the gasoline as a by-product of the gas production operations and its extraction as a step in the production and conditioning of the gas. Likewise, the oil production functions of Lone Star were subordinate in size to the utility operations and bore a direct and close relationship to the production of natural gas. Most of the oil produced by Lone Star came from wells which also produced natural gas, and all of the oil was produced from wells which were originally drilled for gas in fields where gas was known to exist. It had never been the policy of the system to explore and drill for oil. The natural gas produced from wells which also produced oil was considered substantial in amount, being $9 \%$ of the total natural gas produced by the system. The Commission concluded that both the gasoline and oil operations of Lone Star were retainable as other businesses with the principal natural gas utility system of the company. ${ }^{448}$ Substantially the same situation prevailed in connection with the gas utility operations of the Columbia Gas \& Electric Corporation system, where gasoline and oil operations were held to be retainable. ${ }^{449}$

\section{Transportation}

The first case involving the retention of transportation properties under the other businesses clauses was that of the American Water Works \& Electric Company. Among other enterprises, Water Works was engaged in the electric railway and bus business. The explanation of this business was historical. The interurban railway business was once flourishing but had declined and had been abandoned where possible. In

${ }^{448}$ Lone Star Gas Corporation, i 2 S.E.C. 286 (1942).

${ }^{449}$ Columbia Gas \& Electric Corporation, I 7 S.E.C. 494 (1 944). Accord: Pennsylvania Gas \& Electric Corporation, Release No. 8490 (September 3, 1948), and Philadelphia Company, Release No. 8242 (June 1, 1948). 
some cases, however, due to state regulatory commissions, the interurban lines could only be abandoned by substituting bus lines. The transportation functions of the company were carried on in the same territory with the integrated utility systems and contributed some revenues. There was evidence of economies resulting from the joint use of personnel and facilities by the utility and transportation businesses. In the light of these facts and of the minor importance of the company's interest in the transportation functions, and in consideration of the difficulty the company would face in satisfactorily disposing of its interests in such businesses, the Commission held that their retention was necessary and appropriate in the public interest and not then detrimental to the proper functioning of the integrated utility system, but provided that the company should not expand its transportation interests, except to the extent necessary to furnish adequate service to the territory then served, without express approval of the Commission. ${ }^{450}$ It will be noted that each of the reasons given by the Commission to justify retention in this case was later rejected as invalid in other cases.

In The North American Company case, the Union electric properties included an electric railway company which operated a freight line I I miles long over which most of the coal requirements of the system were shipped. Purchasing, warehousing, accounting, recording, property valuation, and tax matters were centrally handled for the railway company by the Union group. The railway purchased the current used in its operations from Union. North American claimed that the ownership of this road was good insurance against a coal car shortage. The Commission did not agree with this latter contention, since all cars were subject to the orders of the Interstate Commerce Commission and the government, but due

\footnotetext{
${ }^{450}$ American Water Works \& Electric Company, 2 S.E.C. 972 (1937).
} 
to the small size, the location, and the use of the road it was held to be retainable. ${ }^{451}$ It was indicated, however, that the Commission believed that this approached the limits of vertical ownership permitted by the Act.

North American also was the parent of Capital Transit Company, which operated the bus and trolley system in the District of Columbia and adjacent portions of Maryland. Retention of this property was sought along with the integrated electric utility system of Washington Railway \& Electric Company. The company pointed to the long historical association between the electric and transportation properties of the system. Evidence of joint ownership of electric facilities by these systems and their interchange of facilities was adduced. North American claimed that the transportation properties were retainable under the other businesses clauses and, further, that it was beyond the power of the Commission to order a divestment thereof by virtue of a joint resolution of Congress dating back to I 933 which appeared to prohibit divestment. The Commission held that this resolution and the Act were inconsistent and that the later law should prevail, and also that the vast and complex transportation business of Capital Transit could not be retained under the other businesses clauses. ${ }^{452}$

North American further sought to retain the transportation properties of a subsidiary in the electric utility system of Illinois Traction Company. These properties consisted of a steam and electric railroad operating in a web around St. Louis and East St. Louis, and also running to Peoria, Springfield, Bloomington, Decatur, and Danville, Illinois. Also included were a dock and barge loading plant for the Missis-

${ }^{401}$ The North American Company, i I S.E.C. 194, 227 (I942). Cf., Philadelphia Company, Release No. 8242 (June I, I948), and American Gas \& Electric Company, Release No. 6333 (December 26, I 945 ).

${ }^{452}$ The North American Company, I I S.E.C. 194, 233 (I 942). 
sippi River coal and coke traffic, passenger buses, terminal facilities, and a toll and railroad bridge across the Mississippi River. The reasons advanced to support retention were (I) historical association of electric and railroad facilities; (2) the fact that the railroad was the largest customer of one of the main electric companies in the system; (3) that much equipment owned by such electric company was primarily devoted to serving the road and that telephone facilities owned by the road were also used by the power company; (4) that certain joint facilities were cared for by joint personnel; (5) that economies resulted from common ownership; and (6) that it was difficult to sell the railroad properties. The first, second, and sixth reasons were held to have no bearing on the question. The third, fourth, and fifth reasons were held to have some pertinency, but the Commission found that the relationship of the railroad and related properties to the electric utility operations of the retainable systems was not such as to warrant the retention of such properties. ${ }^{453}$

In the Engineers Public Service Company case it appeared that Virginia Electric \& Power Company owned and operated street railway and bus facilities serving four cities in Virginia, and an interurban bus service between two of such cities. These four cities were all within the company's electric service area. On behalf of the retention of the transportation properties the company relied upon ( $\mathrm{I}$ ) the long historical association of the two businesses; (2) the joint use of personnel (235 out of 3,000 employees); (3) the joint use of facilities (the electric and transportation departments shared space in certain office buildings and storehouses, and also shared office furniture and equipment, a heating plant, manholes, poles, rights of way, and some garages and trucks); and (4) the fact that the combined railway and bus operations returned a net in-

${ }^{453}$ The North American Company, I I S.E.C. 194, 250 (1942). 
come. The Commission felt that these reasons were of no aid in distinguishing between a reasonably incidental or economically necessary or appropriate business and any other business, and observed that the existence of a long historical association or the joint use of personnel and facilities, or net profits was perfectly compatible with a combination whose components were not remotely incidental, or economically necessary or appropriate, al though owned and operated under common control. Engineers also claimed that disposition of the transportation properties would be costly and difficult, but this was quickly brushed aside. It was further argued that the transportation department was incidental because it furnished free transportation to a portion of the employees of the electric system, because its vehicles carried advertising displays for the electric system without charge, and because it purchased a portion of the latter's electric energy. The answer to these contentions was stated by the Commission in this manner:

". . . While the furnishing of products or services which are useful in conducting the electric utility business is relevant to a determination of the incidental character of the proposed other business, the weight to be attributed to these factors, of course, varies with their significance for the successful operation of the business concerned. The record in this case discloses that only a minute portion of the transportation system advertising is devoted to the requirements of the electric system. And a similarly insignificant portion of the transportation system's passengers consist of electric employees using free service. . . . Virginia's transportation properties are not devoted primarily to furthering the operations of its electric system. The transportation department's purchases of electricity amount to less than 4 percent of the total sales of the electric department. And in its physical operations the transportation system 
is entirely unrelated to, and involves operating problems different from the electric business. ${ }^{454}$

Still another line of argument was presented by the company to demonstrate the retainability of the transportation system. It was claimed that separation would increase the operating expenses of both systems. The Commission did not believe that there would be any significant increase in such expenses and that the company failed to take into account numerous savings to be affected by the severance of the transportation system. In regard to the use of joint personnel by the two systems, it was observed that such a situation obtained in practically all cases of this type, and that if controlling weight should be given to the difficulties involved in reallocating the staff and salaries in this case, there would be no reason for not doing so in other cases, no matter how tenuous the relationship between the other business and the utility business.

The record in this case disclosed that the railway property had been carried in the electric plant account and there was an allocation of interdepartmental charges by which the transportation system was charged considerably less than the cost of the electric energy obtained from the electric system, and substantially less than the cost for the use of the other facilities of the electric system. The Commission was of the opinion that these practices were adverse to the interests of consumers, investors, and the public.

For all of the foregoing reasons, it was concluded that the transportation properties of Virginia were not retainable under the other businesses clauses. ${ }^{45}$

${ }^{454}$ Engineers Public Service Company, I2 S.E.C. 4 I, 50 (1942). It was also noted that informal exchange of services between the electric and the transportation departments, wholly unaccounted for on the company books, was not conducive to the proper operation of the electric utility system.

${ }^{155}$ Engineers Public Service Company, I 2 S.E.C. 41,53 (1 942). For almost identical reasons it was contended in the same case that the street railway and 
To the contrary, on the appeal of this case, the Court of Appeals for the District of Columbia stated that substantial evidence had been presented by Engineers from which the Commission might have found that the retention of the transportation businesses of the various Engineers subsidiaries was necessary in the public interest or for the protection of investors or consumers, or if not necessary, at least appropriate for such purposes. Although it was pointed out that the responsibility of making final determinations of fact lay with the Commission, the court reversed the decision of the Commission and directed that further consideration be given the matter by the Commission. ${ }^{456}$ The reasons advanced for the reversal were (I) that the Commission had based its decision upon the theory that other businesses must bear a functional relationship to the utility system, and (2) that the Commission had relied upon its finding that the retention of the transportation system had been detrimental in the past, with no clear finding as to conditions existing at the time of the decision. This conflict between the Court of Appeals, on the one hand, and the Commission and the Circuit Courts of Appeals for the Second and Third Circuits on the other, has previously been discussed at length. It was noted that by

bus systems of Savannah Electric and Power Company and El Paso Electric Company were retainable along with the electric utility systems of those respective companies, except that in the former the transportation system was operating at a loss. Retention was similarly denied. i 2 S.E.C. 41, 69-70, 9 1-92. It was noted in connection with the E1 Paso transportation properties that the existence of common origins and development of electric and transportation properties, the joint use of personnel and facilities and the profitable character of the transportation operations were factors which in the past had been conducive to practices contrary to the interests of investors and consumers and detrimental to the proper functioning of the electric system. A substantially weaker case was presented by the company in an effort to justify the retention by Gulf States Utilities Company of the bus system in Baton Rouge, which was held to be non-retainable. I 2 S.E.C. 41, 72-74. Cf., Central Maine Power Company, i 7 S.E.C. 729 (1 944$)$.

${ }^{456}$ Engineers Public Service Company v. Securities \& Exchange Commission, I 38 F. (2d) 936 (C.A.,D.C., 1943; cert. granted, 322 U.S. 723 ; issues became moot because of divestment of properties in question, 332 U.S. 788 (1947)). 
virtue of the weight of authority and an indirect reference to the matter by the Supreme Court in The North American Company case, the issue has apparently been decided in favor of the functional and operational standard imposed by the Commission under the other businesses clauses. Consequently, the review of the Engineers case directed by the Court of Appeals was never consummated and the decision of that court was tacitly overruled.

A new proposition was advanced in the Cities Service Power \& Light Company case, where retention of a subsidiary operating trolley cars, coaches and motor coaches in Toledo was sought in connection with the Ohio electric properties of the system. It was contended, among other things, that the territory served by the electric utility was improved by the existence of an adequate transportation system to attract industries to that locality. The Commission could find little point in this argument and stated that the issue was not whether the transportation properties should be abandoned and dismantled, but whether they were properly to be joined with the utility properties, and that there was nothing to indicate that the achievement of benefit to the area by the location of the transit properties was in any way dependent upon Cities' ownership thereof. Disposition was accordingly ordered. $^{457}$

Still another new argument was presented by The Commonwealth \& Southern Corporation in connection with the retention of the street railway, trackless trolley, and bus operations of the southern companies in Atlanta, Augusta, Macon, and Rome, Georgia, along with the electric utility properties of the southern system. The city governments of

${ }^{457}$ Cities Service Power \& Light Company, I4 S.E.C. 28 (1943). Also, see The United Gas Improvement Company, 11 S.E.C. 338 (1942), where it was argued, to no avail, that transportation properties were retainable because such properties had derived substantial financial and other benefits from the holding company. 


\section{PUBLIC UTILITY HOLDING COMPANIES}

the said cities and the Georgia Public Service Commission each presented resolutions in opposition to any divestment of the transportation properties in those cities. The resolutions were based upon the propositions that the transportation systems were largely electric operations, with power being supplied from the integrated system, and that joint use was made of facilities. This bolstering of the customary arguments for retention was to no avail and retention was denied. ${ }^{458}$

The latest decision on this question by the Commission was rendered in the Philadelphia Company case. There the company sought to retain its electric railroad and motor bus lines with its electric utility system. In addition to the customary arguments in favor of retainability, the company contended that certain benefits were derived from the use of the "General Departments" of the company. Similar arguments have been discussed under Clause $A$ and were rejected in a like manner here, principally for the reason that the administrative functions supplied by the General Departments had no operating relationship between the transportation system and the operations of the electric utility system. It was noted that the railway properties had a long history of financial difficulties and were an undue burden upon the electric system. Further, there was a possibility that the electric system might be tempted to retard the natural growth of the bus system in order to favor the electric railway. A final argument presented by the company, new in this situation, was that various guarantees and commitments of the Philadelphia Company in respect of the Pittsburgh

${ }^{458}$ The Commonwealth \& Southern Corporation, Release No. 76I5 (August I, I 947). See Texas Utilities Company, Release No. 6373 (January I7, I 946), where an electric system proposed to acquire the stock of a street railway and bus system in Dallas, Texas. The City of Dallas urged approval of the acquisition in order to keep the electric and transportation properties under a financially strong common parent. This and other contentions were rejected, and such acquisition was not permitted under the provisions of Section io (c) of the Act. 
Railways required the continued retention of the transit system. This argument was considered to be without merit for the reason that it assumed that by means of pre-existing contracts the objectives of the Act could be avoided. The conclusion of the Commission was that the requirements of the other businesses clauses were not met by these transportation properties. ${ }^{459}$

\section{Steam and Hot Water}

Where electricity is produced by the use of steam turbines, as distinguished from water power, one of the by-products of the utility business is a supply of steam. In numerous instances utilities have capitalized upon this by-product to their financial advantage. For example, one of the Engineers Public Service Company electric utility subsidiaries sold the steam which it produced in connection with the generation of power to three large industrial customers located in the immediate vicinity. The plant was designed to burn a variety of fuels, which were obtained as waste from the industrial establishments supplied with steam. The record disclosed that the production of steam in the generating plant, through the use of machinery specially designed to enable the combined operation, was both in intent and in fact integrally related to the production of electric energy, according to the Commission, and therefore retention of the steam business was permitted. ${ }^{460}$

In the Cities Service Power \& Light Company case it appeared that exhaust steam from the boilers of one of the electric generating plants was sold commercially. The operation of this steam business made it possible to keep the boilers

${ }^{459}$ Philadelphia Company, Release No. 8242 (June I, 1948), affirmed in Philadelphia Company v. Securities \& Exchange Commission, 177 F. (2d) 720 (C.A.,D.C., I 949).

${ }^{40}$ Engineers Public Service Company, 12 S.E.C. 4 I ( 942 ). 


\section{PUBLIC UTILITY HOLDING COMPANIES}

in a ready condition for electric service. This business was held to be retainable. ${ }^{461}$ The same company also provided hot water service. The latter was provided by facilities not connected with and distinct from the steam and electric properties. The hot water system had been acquired in the course of growth of the company in connection with the acquisition of certain small electric generators and non-condensing steam engines. Although this equipment had been abandoned for electric purposes, the boilers were being used to provide the hot water heat. Since there was a complete operational separation between the hot water heating and the electric systems, the retention of the former was not permitted. ${ }^{462}$

On the other hand, one of The North American Company electric subsidiaries also operated a hot water heating business. Part of the steam produced in connection with the generation of the company's electricity passed through heat exchangers, as a result of which the heat contained in the steam was transferred to the water in the heating system. The hot water was then pumped through mains to the customers' premises and then back through the mains of the heat exchanger. For the twelve months ended June 30, I950, the hot water business resulted in a net loss of $\$ 6,767.00$. Retention of this heating business as incidental to the electric operations of the system was permitted. ${ }^{463}$

Again, in the Cities Service case one of the company's subsidiaries sold steam industrially from a site acquired and designed to serve as a generating plant when future conditions so required. The installation of boilers which supplied the steam and which were designed for future use in generating

${ }^{401}$ Cities Service Power \& Light Company, 14 S.E.C. 28,4 I (1943). Accord: General Public Utilities Corporation, Release No. 10982 (December 28, 1951). Cf., The North American Company, i I S.E.C. I 94 ( 942 ).

${ }^{462}$ Cities Service Power \& Light Company, 14 S.E.C. 28,41 ( 1943).

${ }^{463}$ The North American Company, Release No. 10320 (December 28, 1950). 
operations helped to carry the plant site profitably. This business was held to be retainable. ${ }^{464}$ An even more liberal decision may be found in the American Gas \& Electric Company case, where retention was permitted of an old boiler plant from which the generator turbine had been removed. ${ }^{465}$

Another Cities Service subsidiary operated a small steam business in the City of Denver, Colorado. The steam business was not physically connected with the electric business of the company, separate boilers being used to generate steam for heating purposes. The company contended, however, that this business fostered good will, and that if some of the present steam customers were forced to install local facilities for heating, they might also install their own electric generating equipment. The Commission did not believe that the historical connection of the steam and electric businesses and the company's desire to create good will by expansion into unrelated fields made the steam business reasonably incidental or economically necessary or appropriate to the utility operations. ${ }^{466}$ This would seem to be a highly objective approach to a highly subjective problem, probably of considerable moment to the utility company. In the Philadelphia Company case, one of the system subsidiaries operated three steam plants in the downtown business section of Pittsburgh, furnishing steam heating service to certain buildings. Only one of these plants was physically connected with the electric properties of the systems, and it furnished steam for the operation of a generating station of the electric system, with the exhaust steam being returned and delivered to its customers. It was noted that the steam heating service made it possible for the power company to sell electricity to consumers

${ }^{* 34}$ Cities Service Power \& Light Company, I4 S.E.C. 28,49 (1 943 ).

46: American Gas \& Electric Company, Release No. 6333 (December 26, $19+5)$.

Cities Service Power \& Light Company, I4 S.E.C. 28, 68 ( 1943). 


\section{PUBLIC UTILITY HOLDING COMPANIES}

who might otherwise generate their own current in connection with their steam heating, a situation identical with that of the Denver steam properties of Cities Service. However, it was held here that the steam heating business as a whole was reasonably incidental and economically appropriate to the electric utility operations of the company. ${ }^{467}$

\section{WATER}

In the early American Water Works \& Electric Company case, the facts showed that, in addition to the integrated electric and gas utility systems and certain other businesses, the company owned or controlled a substantial number of water operating and holding companies which did $30 \%$ of the business of the entire system. The Commission observed that the water properties had been a substantial and stable source of revenue and that many of the problems of management of the water companies were closely related to those arising in connection with the management of the gas and electric utilities. Retention of the water businesses was permitted. ${ }^{468} \mathrm{Al}$ though this decision has not been reversed, its reasoning has been rejected on numerous subsequent occasions, and the case should not be considered authoritative.

The Southern Union Gas Company gas utility system included two small water systems, one serving 24 customers in Pyote, Texas, and the other serving 184 customers in Lovington, New Mexico. Both of these towns were supplied with gas by the system. In the light of the small size of these enterprises they were held to be retainable. ${ }^{460}$ This is, of course, another questionable decision.

The Commission was in better form in the Engineers Public Service Company case. There it was shown that Gulf

${ }^{467}$ Philadelphia Company, Release No. 8242 (June I, I 948).

${ }^{468}$ American Water Works \& Electric Company, 2 S.E.C. 972 ( 937 ). Cf., Republic Electric Power Corporation, 3 S.E.C. 992 (1938).

${ }^{163}$ Southern Union Gas Company, I 2 S.E.C. I 16 ( ( $\left.94^{2}\right)$ 
States Utilities Company owned and operated a water business serving seven communities. The company pointed to the joint use of supervisory, administrative, and repair personnel and water testing, automotive and other facilities by the water and electric systems, and to the difficulty of disposing of the water properties, since the water equipment was located on the site of the electric equipment. It was asserted that the water facilities were "inextricably interspersed" with the electric facilities. The company also claimed that increased expenses would result from a severance. The Commission took the position that the freed time of the employees who formerly worked part time for the water business would not be wasted and adverted to anticipated beneficial effects upon the electric business arising out of the concentration of the undivided attention of the company's organization to the electric operations. The joint use of personnel and equipment was observed to be mainly non-operational in character, and the difficulties of severing the water properties were not deemed to be acceptable as tests of their retainability. As a consequence, compliance with the other businesses clauses was not found. ${ }^{4 i 0}$

Certain subsidiaries of Cities Service Power \& Light Company owned water rights necessary to supply condensing water to steam boilers of the Rocky Mountain electric system, and water storage facilities for use in the generation of electricity. It was held that these water operations were clearly reasonably incidental and economically necessary and appropriate to the proper functioning of the electric utility system. ${ }^{471}$ Another subsidiary in the same system rendered water service in Santa Fe, New Mexico. There appeared to be

${ }^{400}$ Engineers Public Service Company, I2 S.E.C. 41 (1942). Accord: The North American Company, Release No. 10320 (December 28, 1950); The Middle West Corporation, I5 S.E.C. 309 (I 944); and The North American Company, i I S.E.C. 194 (1942). But see The Middle West Corporation, 18 S.E.C. 296 (1945), on the question of intermingling of assets.

${ }^{471}$ Cities Service Power \& Light Company, I4 S.E.C. 28 (1 943 ). 


\section{PUBLIC UTILITY HOLDING COMPANIES}

some operating connection between the water works facilities and a small generating plant of the system at that point, but the distribution facilities of the water operations had no connection with the generating plant. Disposition was ordered of the portion of the water facilities in Santa Fe not necessary for the proper maintenance and operation of the generating plant. ${ }^{472}$

In The Middle West Corporation case it was argued, in addition to the usual reasons for retention, that the water operations were powered by electricity from the company's system and that water operations were continued in order to maintain good will. The Commission considered these to be factors which might exist no matter how unrelated the nonutility business might be, observing that "to lose sight of the essential requirement of operating relationships is to depart from the basic policy of the statute," and ordered disposition of the water properties. ${ }^{473}$

In the General Public Utilities Corporation case one of its subsidiaries owned a dam and reservoir about five miles from a steam generating station in the integrated electric utility system. Water from the reservoir was carried through a main to the generating station where it was used in the boilers. Along the route taps were taken off to supply about 375 domestic customers. At December 31, I950, the plant account of the water company amounted to $\$ 474,716$ gross and $\$ 37 \mathrm{I}$, 949 net. Operating revenues for 1950 were $\$ 55,8$ I 8 , of which $73 \%$ was received from the GPU system. The company sold $85 \%$ of its water to the system. The Commission found that these water operations were functionally related to the electric

${ }^{47}$ Ibid. See, also, The Middle West Corporation, r 8 S.E.C. 296 (1945), where it was held that the water supply and transmission properties of a water system, but not the water distribution properties, were retainable with an electric utility system. Considerable emphasis was placed upon the difficulty of segregating the electric and water supply and transmission properties.

${ }^{473}$ The Middle West Corporation, i 8 S.E.C. 296,302 (1 945 ). 
utility business of the system and were retainable under the other businesses clauses. ${ }^{474}$

In numerous other cases water properties have been held not to comply with the requirements of the other businesses clauses, and the general rule seems to be that they are not retainable. ${ }^{475}$

\section{ICE ANd Cold Storage}

Virginia Electric \& Power Company owned a small ice business in Williamsburg, Virginia. The ice plant was located in the company's electric service building in that city and functioned primarily as a cooling system for the building in the summer and a heating system in the winter. This ice business was found to be subservient and supplemental to the operation of the electric system and was a by-product of cooling and heating the electric service building. Accordingly, it was held to be retainable. ${ }^{476}$ Another Engineers Public Service Company subsidiary, Gulf Public Service Company, produced and distributed ice in nine communities. The ice properties were acquired together with the electric properties of the system and shared joint facilities and employees with the electric system. Contrary to the situation in Williamsburg, however, these ice operations did not assist in the electric business and were conducted primarily as an independent enterprise. Further, the ice business was unprofitable. Severance of the ice properties was ordered..$^{47}$

The historical relationship of ice and electric utility plants was set forth in The Middle West Corporation case. The

${ }^{474}$ General Public Utilities Corporation, Release No. 10982 (December 28, 195 I).

${ }_{475}$ Cf., American Utilities Service Corporation, 16 S.E.C. I73 (1944); Central Power \& Light Company, 14 S.E.C. 452 ( I 943); American States Utilities Corporation, I 3 S.E.C. 93 (1 943); Peoples Light \& Power Company, I 3 S.E.C. 8I (1943); and Federal Water \& Gas Corporation, 12 S.E.C. 766 (1943).

${ }^{436}$ Engineers Public Service Company, I 2 S.E.C. 41 (1942).

${ }^{477}$ Ibid. Accord: The Middle West Corporation, I5 S.E.C. 309 (1944); Cities Service Power \& Light Company, I 4 S.E.C. 28 (1943). 


\section{PUBLIC UTILITY HOLDING COMPANIES}

initial developments of both industries occurred at about the same time, the end of the r gth century and the beginning of the 2oth century. The original method for producing clear ice was by the use of water from which impurities had been removed by distillation. The electric industry provided steam for both power and distilled water. Further, the ice business had complementary seasonal variations with respect to the use of power, and daily production of ice could be scheduled to increase power production in off-peak hours. The result was that many electric utility companies engaged in the ice business and many properties acquired in the expansion of electric utility companies were joint ice and electric plants. During the I 920's and I930's, however, ice began to be produced by the use of raw water in an ammonia process, and the use of exhaust steam for distillation was no longer necessary. Also, the decline in domestic consumption of ice due to mechanical refrigeration considerably narrowed the market for ice, and many companies abandoned their ice plants. Some, however, retained and improved their ice businesses. As a general rule, then, there usually does not now exist a high degree of operational relationship between ice and electric utility businesses and the ice business is merely a remnant of a once feasible economic union. ${ }^{478}$

One of the Middle West electric utilities operated ice manufacturing and distributing facilities in over 50 localities in its service area. The ice business and the electric business jointly utilized substantial personnel, offices, equipment, supplies, and material. It was indicated that substantial increases in expenses (not set forth) would occur in both the electric and the ice businesses if they were separately owned. The ice operations secured power from the company's electric facilities. It was characteristic of the ice business in the territory served that heavy use of power for ice manufacturing offset

${ }^{488}$ The Middle West Corporation, I8 S.E.C. 296, 302-303 (1945). 
low seasonal retail power demands, and that the daily power demands of the ice business could be satisfied during daily off-peak power periods on a system-wide basis. The predominant business throughout the area served was the production of fruits and vegetables. The company's ice plants operated in a pool which coordinated all ice production, shipping, and distribution facilities so that all areas might be adequately served. Because of the size of the territory involved, planting and harvesting were staggered. Centralized operation of the ice facilities and joint ownership with the electric facilities prevented a heavy drain in any one area and permitted scattered plants to share in meeting the ice load. It was consequently held that this ice business was substantially related to the electric utility operations of the company, and hence retainable. ${ }^{479}$

Another Middle West subsidiary operated ice production, storage, and distribution facilities in its electric service area in west Texas. The operational relationships between the ice and the electric businesses were substantially the same as those described in the foregoing paragraph. In addition, it was indicated that in many instances it would be physically impracticable to separate the ice and power production facilities and impracticable to permit outside control of the ice production facilities, since they were so near to and closely related to the electric plants. The Commission found that the ice business not only facilitated efficient use of the electric properties, but was also so closely related thereto as to create extreme difficulty in a separation of the businesses or a hazard to the electric properties if the ice facilities were operated by personnel not subject to the control of the electric staff. Retention was permitted. ${ }^{480}$

${ }^{473}$ The Middle West Corporation, i 8 S.E.C. 296, 303 (1 945 ).

${ }^{480}$ The Middle West Corporation, 18 S.E.C. 296, 305 (1945). Cf., West Texas Utilities Company, Release No. 6320 (December 20, 1945), and The North American Company, 1 1 S.E.C. 715 (1942). 
Other Middle West subsidiaries operated ice plants in various locations where electric service was provided by the system companies. Evidence was adduced to show considerable joint use of personnel and facilities by the ice and electric businesses. Also, it was shown that physical separation of the two functions would be extremely difficult. However, the Commission requested power consumption figures and discovered that the ice properties augmented the peaks in electric consumption rather than aided in the equalization of power production. Physical proximity and mechanical difficulty of separation, the Commission felt, were problems relating only to the time and manner of disposition rather than to the issue of retainability. The lack of a showing of operational relations between the two businesses prevented a finding of compliance with the Act. ${ }^{481}$

In a more recent case, involving The North American Company system, retention was sought of two ice properties belonging to the electric system in Missouri. One of the ice and storage plants involved shared certain premises with the electric properties. Both of the ice properties obtained their electricity from the electric system at regular rates and their steam and distilled water at cost. The Commission commented that there had not been shown in this case the type of operating or functional relationship which Congress contemplated when it established the standards of the other businesses clauses, and accordingly ordered disposition of the ice properties. ${ }^{482}$

\section{Appliances}

Several of the electric and gas utility subsidiaries of Engineers Public Service Company were also engaged in the

${ }^{451}$ The Middle West Corporation, I 8 S.E.C. 296, 308 and 310 (1945). Permission was given the company to adduce further evidence on the issue of the complementary use of power by the ice properties. Such evidence was held 
business of merchandising and jobbing appliances. These activities were not conducted for profit but were designed to promote the sale of electricity and gas by educating the public as to the benefits to be derived from the use of appliances that had not then found wide acceptance. It appeared that sales efforts were discontinued in cases where the appliances met with public approval. The appliance sales themselves resulted in an operating deficit but increased sales of gas and electricity. The Commission held that the electric appliance business was reasonably incidental or economically necessary or appropriate to the operations of the integrated electric utility system to which it pertained, and that the gas appliance business was likewise retainable with the integrated gas utility system with which it was connected. ${ }^{483}$ It was noted that there had been earlier efforts on the part of independent appliance dealers to prohibit public utilities from engaging in the appliance business. ${ }^{484}$ Between 1930 and 1937 the legislatures of 23 states were presented with bills designed to prohibit utility merchandising. In only two states, Oklahoma and Kansas, were such bills enacted into law, and the law of the latter state was declared unconstitutional. Congress, however, did not pass upon the question in the Act.

One of the integrated gas utility subsidiaries of Cities Service Company maintained a "new business" department which handled the sale of gas appliances and made routine adjustments to such appliances so that customers could use gas more effectively and economically. The essential purpose of the

to be unsatisfactory and disposition was ordered in The Middle West Corporation, Ig S.E.C. 743 ( 1945 ).

${ }^{482}$ The North American Company, Release No. I0320 (December 28, 1950).

${ }^{483}$ Engineers Public Service Company, I2 S.E.C. 41 (1942), affirmed in Engineers Public Service Company v. Securities \& Exchange Commission, ${ }_{3} 8$ F. (2d) 936 (C.A.,D.C., I 943). Accord: American Water Works \& Electric Company, 2 S.E.C. 972 (1937).

${ }^{484}$ Engineers Public Service Company, I 2 S.E.C. 41 at 55, footnote 9 (1942). 
department was to promote competition with other types of fuel. This business was held to be retainable with the integrated gas utility system. ${ }^{485}$

\section{Service Companies}

Service companies were the source of many of the abuses which the Act was designed to correct, and consequently received special attention in the Act. ${ }^{486}$ However, they also fall within the category of "other businesses," and must therefore meet the tests of the other businesses clauses in order to be retainable.

In the case of American Gas \& Electric Company it appeared that a service company owned by the system furnished management, advisory, engineering, and other services to the system companies. Such services were rendered through the following departments: administrative; finance and accounting; legal; statistical; filing, mail and telephone; stock, record and dividend disbursement; commercial and new business; purchasing; insurance and retirement records; auditing; field auditing; field appraisal; and engineering. The cost of these services was recovered from the various system companies on a complicated allocation basis. It appeared that control and coordination of the entire system was effected through the service company. All of the principal officers in the system were paid through the service company. The Commission found that such of the operations of the service company that were related to the Central system of American Gas \& Electric Company were retainable as other businesses. ${ }^{487}$

Other decisions have ordered divestment of service com-

${ }^{485}$ Cities Service Company, I 5 S.E.C. 962 ( 1944). Also see Community Gas \& Power Company, 13 S.E.C. 532 (1943), and Lone Star Gas Corporation, r 2 S.E.C. 286 ( 1942$)$.

${ }^{886}$ See Sections $I_{3}$ and 14 of the Act, ${ }_{5}$ U.S.C.A., Sections $79 \mathrm{~m}$ and $79 \mathrm{n}$.

${ }^{457}$ American Gas \& Electric Company, Release No. 6333 (December 26, 1 945). Accord: Columbia Gas \& Electric Corporation, r7 S.E.C. 494 (1944). 
panies because they were not related to a utility business, they were not related to a retainable utility business, or were they far too large in scope in comparison with the retainable system. $^{488}$

\section{Real Estate and Related Enterprises}

It is obvious that the ownership of water rights and water storage facilities necessary to supply condensing water to the steam boilers of the generating station of an integrated electric utility system is permissible. ${ }^{489}$ Also, the business of owning dams and land adjacent thereto, flowage rights on various lakes and rivers, and a system of canals through which water for power is delivered to the generating stations of an electric utility system is retainable by such system. ${ }^{490}$

In the early case of American Water Works \& Electric Company, it appeared that the system owned a toll bridge which it had acquired in connection with its operation of an interurban line. This bridge was located in the electric and gas service territory of the system and contributed some revenues. There was some evidence of the joint use of personnel and facilities. In view of these facts and of the minor importance of the system's interest in this property, and in consideration of the difficulty of disposing of the property in a satisfactory manner, the Commission held that the toll bridge was retainable. ${ }^{491}$ It has been previously noted, however, that the Commission has subsequently taken the position that the existence of an unfavorable market has no pertinency to the ques-

${ }^{488}$ Cities Service Company, Is S.E.C. 962 (i 944 ), and Engineers Public Service Company, I 2 S.E.C. 4 I (1942). The latter situation prevailed in Standard Power \& Light Corporation, 9 S.E.C. 862 ( I 94 I), and the Commission deferred entry of an order pending reduction in the scope of the functions of the service company.

${ }^{430}$ Cities Service Power \& Light Company, 14 S.E.C. 28 (1943).

${ }^{450}$ Central Maine Power Company, Release No. 7985 (February 20, 1948).

${ }^{4}$ American Water Works \& Electric Company, 2 S.E.C. 972 (1937). 


\section{PUBLIC UTILITY HOLDING COMPANIES}

tion whether property may be retained under the Act. ${ }^{402}$ Further, in regard to the toll bridges owned by one of the electric utility systems of Engineers Public Service Company, the Commission held that the common origins and development of the properties, the joint use of certain personnel and facilities, and the profitable character of the business did not render it reasonably incidental or economically necessary or appropriate to the operations of the electric system, nor did such factors make retention of the properties necessary or appropriate in the public interest or for the protection of investors or consumers. ${ }^{493}$

In the American Gas \& Electric Company case, it was shown that the real estate of the electric utility systems was owned by separate companies. The reason for this was to provide flexibility in the purchase and disposition of real estate and to avoid incurring the complications of restrictive provisions in the mortgages of the operating companies. Such allied business was held to be retainable ${ }^{494}$ The same system also included a company which owned a housing project designed to provide proper housing conditions for employees of the system near one of its generating stations. Included in the project were i 83 lots, one house and lot, and a water supply and sewerage system. The company had also advanced money on mortgage loans to two employees. There was evidence to show that it would have been extremely difficult to provide proper accommodations for the system employees in any other manner, and consequently retention of this real estate company was permitted under the other business clauses. ${ }^{45}$

Another subsidiary company in the American Gas \& Electric Company system carried on quarrying operations which

${ }^{402}$ The North American Company, I I S.E.C. I 94 (1942).

${ }^{493}$ Engineers Public Service Company, I 2 S.E.C. 4 I (1942).

${ }^{404}$ American Gas \& Electric Company, Release No. 6333 (December 26, I 945 ), mimeo. p. 24.

${ }^{405}$ Ibid. 
originally had their origin in connection with the building of one of the dams in the system. At the time in question, the quarrying business had no direct relationship to the electric operations of the system. However, the quarry was near the dam and it was proved that the blasting operations of the quarrying business had to be done very carefully in order not to imperil the dam. Retention was urged by the system because an independent operator might so conduct the quarrying business as to endanger the dam. This was a marginal case, but in view of these practical considerations and the small size of the business its retention was permitted. ${ }^{496}$

The North American Company sought to retain an amusement park operated in conjunction with its electric and transportation business in the District of Columbia and adjacent portions of Virginia and Maryland. The park was operated by Glen Echo Park Company, a subsidiary, in Maryland close to the District of Columbia. The system claimed that this business increased traffic on the transit lines, which in turn increased the consumption of electricity, and that it was profitable. The Commission ordered divestment of this business, noting that one of the clearest of the Congressional objectives in enacting Section I I (b) (I) was to require that public utility systems divest themselves of large investments in unrelated fields such as this. ${ }^{497}$

One of the subsidiaries in the natural gas utility system of Peoples Light \& Power Company owned and operated a rice farm composed of 5,700 acres of land and warehouses for the storage of rice. The system contended that there was a definite possibility of discovering gas reserved on the farm properties and that consequently the system was in a better bargaining position in dealing with the various possible suppliers of gas for the system. It was also contended that the

${ }^{403}$ I bid.

${ }^{197}$ The North American Company, I I S.E.C. 194 (1942). 


\section{PUBLIC UTILITY HOLDING COMPANIES}

property had good oil prospects and that such potentialities gave the land a latent value of which the system's stockholders would be deprived if the property were sold before it was fully prospected. The Commission considered that such arguments were primarily directed to the retainability of the mineral rights and held that the farm business must be divested, although disposition of the mineral rights was not required. ${ }^{498}$

\section{Miscellaneous}

One of the subsidiaries of General Public Utilities Corporation was engaged in servicing the system's life insurance plan for employees. The annual premiums handled by the company aggregated about $\$ 1,900,000.00$, and its expenses of operation were about $\$ 25,000.00$ a year. The company made no profit on its operations. In addition to administering the life insurance plans of other companies in the system, it also performed the same function for certain companies which had been divested by General Public Utilities Corporation. The Commission found that the activities of the company relating to the servicing of the insurance policies of the employees in the system were reasonably incidental and economically necessary and appropriate to the operations of the system, but required discontinuance of the servicing of insurance policies of employees of companies which were no longer part of the integrated system. ${ }^{499}$

Another subsidiary in the same system was the settlor of a pension trust created in 1937. Its original capital was delivered to the individual named as the pension trustee and

${ }^{493}$ Peoples Light \& Power Company, 20 S.E.C. 357 (1945). Also see American Water Works \& Electric Company, 2 S.E.C. 972 (1937), holding that unrelated farm land and office buildings did not meet the requirements of the other businesses clauses.

${ }^{409}$ General Public Utilities Corporation, Release No. 10982 (December 28 , I95I). 
since that time it had never had any receipts or disbursements. Deposits were made in the pension fund on an actuarial basis by various system companies until I 939, when the various participants either adopted new plans or discontinued their old plans. All of the new pension plans called for liquidation of the deposits under the old plan by the payment of pensions to retired employees out of the old pension fund before using the accumulations under the new plans. Almost all of the participating companies which did not establish new plans were no longer in the system, but it was evident that some time would elapse before the final liquidation of their trust accounts could be made in accordance with their trust agreements. The 1937 trust agreement was irrevocable and it was the opinion of company counsel that the settlor company should be kept alive in order to eliminate any possibility that the trust would be defective. The Commission held that retention of this company was permissible, but indicated that it should be liquidated at the earliest practicable date. ${ }^{500}$

Situations involving the retainability of telephone facilities have seldom arisen under the Act. This is probably due to the widespread domination of that field by American Telephone \& Telegraph Company. In one early case, decided before the Commission had adequately oriented itself, the retention of a small telephone property was permitted in connection with a combined electric and gas utility system. ${ }^{501}$ No operational relationship was shown between the telephone business and the utility business. In later decisions, however, divestment of telephone properties was ordered ${ }^{502}$ Under the current interpretation of the other businesses clauses by the Commission, it would be extremely difficult for an applicant

${ }^{500}$ Ibid.

${ }^{501}$ Republic Electric Power Corporation, 3 S.E.C. 992 (I938).

${ }^{802}$ American Utilities Service Corporation, I6 S.E.C. 73 ( 7944 ); American States Utilities Corporation, I 3 S.E.C. 93 (1943). 
to succeed in retaining a telephone system with either a gas or an electric utility system.

Several utility systems engaged in the water business also provided sewerage facilities. One of these, Southern Union Gas Company, a natural gas utility company, furnished sewerage disposal services to 2 I 3 customers in a small New Mexico town. In consideration of the small size of this enterprise the Commission permitted its retention under the other business clauses. ${ }^{503}$ The validity of this holding at the present date is questionable. Disposition of sewer facilities was ordered in a later case. ${ }^{504}$

A subsidiary in the American Light \& Traction Company system, Milwaukee Solvay Coke Company, manufactured and sold coke and coke by-products, and furnished the system with a substantial portion of its requirements of manufactured gas for the City of Milwaukee. The introduction of natural gas into the area was contemplated, in which event Milwaukee Solvay would continue in business but would reduce its gas supplies to a stand-by basis and for peak-shaving. The Commission found that Milwaukee Solvay was currently retainable as an incidental business, but reserved jurisdiction to reconsider the question if and when it appeared that there had been a substantial change in the relationship of the company to the gas utility system. ${ }^{505}$ The future answer may be found in the case of Cities Service Power \& Light Company. In this case one of the subsidiaries of the system had originally produced manufactured gas for system use and had also de-

${ }^{503}$ Southern Union Gas Company, 12 S.E.C. I 16 ( 1942 ).

${ }^{504}$ Federal Water \& Gas Corporation, I 2 S.E.C. 766 (1943). It should be noted that the divestment in this case was proposed by the utility system itself. Also see Peoples Light \& Power Company, 1 3 S.E.C. 8 I (1943), where divestment of irrigation properties was ordered.

${ }^{505}$ The United Light \& Railways Company, Release No. 7951 (December 30, 1947), affirmed in Panhandle Eastern Pipe Line Company v. Securities \& Exchange Commission, I 70 F. (2d) 453 (C. A., 8th Cir., 1948). 
veloped a market for tar compounds which were by-products of the company's manufactured gas business. After the system changed to natural gas, this company continued the tar business, obtaining its tar from other gas manufacturers. The Commission was unable to discern any relationship between the tar works and the utility operations of the system, and disposal of the tar business was decreed. ${ }^{506}$

\section{Summary of the Requirements of the \\ Other Businesses Clauses}

The problems arising from Congressional revisions of complicated bills are well exemplified by the other businesses clauses. The second other businesses clause appended at the end of Section II(b)(I) was the result of the "Minton Amendment" which was inserted in the holding company bill in the hectic closing days of the first session of the $74^{\text {th }}$ Congress. The second clause is inconsistent to a certain extent with the first clause, and this led to considerable difficulty in the proper interpretation of these provisions of the Act. The same situation prevailed in the case of Clause $B$, where the Barkley Compromise provisions were hastily inserted into the bill. In both instances various holding company systems justifiably took advantage of the ambiguities in the law to urge the retention of many properties contrary to the intention of the original authors of the bill. However, the Commission consistently applied a narrow interpretation of the questionable provisions so as to effectuate the fundamental purposes of the Act.

More explicitly stated, the issue was whether all "other businesses" sought to be retained by an integrated utility system must be functionally and operationally related to the utility system, as required by the first other businesses clause,

${ }^{306}$ Cities Service Power \& Light Company, 14 S.E.C. 28 (1943). 
or whether nonutility "other businesses" can be retained upon a mere showing that they are necessary or appropriate in the public interest or for the protection of investors or consumers and not detrimental to the proper functioning of the utility system concerned. The test imposed by the Commission was stated as follows: Having in mind the protection of investors, the public interest and the proper functioning of an integrated utility system, is the retention of a particular nonutility business reasonably incidental to or economically necessary or appropriate to the operations of a retainable utility system? This, of course, is the functional or operational test. In three test cases the Commission was supported in this view of the matter by the Courts of Appeals of two circuits and was reversed by the Court of Appeals for the District of Columbia. The Commission considers the matter to have been tacitly settled by the Supreme Court of the United States in The North American Company case and has continued to apply the functional requirement described above.

Various and sundry reasons have been advanced in support of the proposition that certain other businesses were functionally and operationally related to the utility system concerned. Among these have been long historical association and common origins of the utility and other businesses, physical proximity of the properties, substantial and stable income of the other businesses, and the difficulties involved in separating the utility and the other businesses or in disposing of the latter. Each of these reasons has been condemned by the Commission as having no bearing upon the issue of operational relationship to the utility enterprise. It has also often been urged that the joint use of personnel and facilities by the utility and the incidental businesses made retention possible. However, the Commission insists that unless the economies arising from such joint use of personnel and facilities are economies in the operation of the integrated utility system, they do not furnish 
adequate grounds for a finding of compliance with the other businesses clauses.

Another restriction imposed by the Commission upon other businesses is that they must not be grossly out of proportion in size to the utility system concerned. The rule seems to be that the other businesses must be subordinate in size and importance to the utility business. This requirement is not stated in the Act but is probably justified by the context of the other businesses clauses and the announced purposes of the Act. The Commission has permitted an exception to this rule in the case of natural gas production and transmission properties of a natural gas utility system, in view of the nature of the industry and the particular problems involved.

A number of holding companies contended that the Act did not require divestment of "investment" interests, that is, interests in companies insufficient to make them subsidiaries of the holding company within the definition of the Act. It was argued that such non-subsidiary interests were not "operations" of the holding company system as provided in Section I I (b) ( I) of the Act. The Commission held that the ownership of such investments did constitute an "operation" of the utility system, and that they were definitely subject to the provisions of the other businesses clauses. Furthermore, the Commission has indicated, but not held, that nonsubsidiary utility investments are possibly not retainable under either clause.

Turning to the retainability of specific enterprises, it may be said that, generally speaking, retention has been permitted in cases involving the production of coal for an electric utility using steam power, the production and transmission of gas for a natural gas utility, the sale of steam and hot water for heating purposes by a steam electric utility, the merchandising and jobbing of appliances by both electric and gas utilities, and the furnishing of administrative and other services for such 


\section{PUBLIC UTILITY HOLDING COMPANIES}

utilities. There have been notable exceptions in each instance, however. Divestment has usually been ordered of petroleum, transportation, and water businesses by virtue of the fact that they are not ordinarily operationally related to the functions of electric and gas utilities. The cases are fairly well divided as to the retainability of real estate businesses and ice and cold storage facilities, the decision in each instance depending upon the evidence or lack of evidence as to the functional connection between the other business and the utility business.

Except for a few early cases involving other businesses small in size, the Commission has adhered rather strictly to its narrow interpretation of the other businesses clauses in spite of the ambiguity of the second clause. It has been said that the myriad, promiscuous activities and investments of some of the holding company systems were a prime cause of investors' losses. If so, the Commission has furthered the ultimate objectives of the Act by its application of the other businesses clauses. 


\section{Chapter 5}

\section{Conclusion}

$7 \mathrm{HE}$ story is told that during the height of the customer ownership campaigns in the twenties, when the savings 1 of many small uneducated investors were being channeled into the treasuries of the giant public utility companies, a Czechoslovakian employee of the Electric Bond \& Share Company system sold the stock of that company in the Pennsylvania coal fields and assured his customers: "... With this stock push the button, and if the light shines, you know your money is safe." Ironically enough, before, during, and after the depression of the early thirties, people went right on pushing the button and the light never ceased to shine, but a large proportion of these investments vanished into oblivion. Insull's "fairyland of light and power" prospered and expanded, while the savings of many of the investors in his and other holding company securities were lost beyond recall. The Public Utility Holding Company Act of 1935 was designed to preserve the good in this situation and to eradicate the evil. How well has it succeeded with this purpose?

Numerous Congressmen, Senators, and witnesses testifying before the committee considering the holding company bill predicted that the industry would be wrecked, disintegrated, and annihilated by the provisions of this bill, and that appalling losses would be suffered by investors. The integration provisions of the bill were labeled a death sentence for the whole American philosophy of government and economics and an invitation to communism. And the attacks were continued by holding company executives and others long after the bill became law. The Securities and Exchange Commission began its long and laborious task in a cautious fashion, en- 
deavoring to feel its way ahead slowly, rather than to muddy the waters with impetuous action. A few of its early decisions, such as that of American Water Works \& Electric Company, were ill-conceived in the light of later rulings, but the mistakes were inconsequential and, in any event, they favored the utilities.

As the captains and the kings of the supermanagement days of the twenties departed, as the tumult, the shouting and the recriminations accompanying the enactment of this legislation faded away in the distance, the realization slowly descended upon the industry that the Act was constitutional, that the Commission was determined to accomplish its assigned mission, and that the divestments and rearrangements required by the Act were not as disastrous as originally advertised. In fact, they have not been disastrous at all. It is no doubt true that the Commission has squeezed a lot of water out of the holding company sponge, but the water was placed there largely in the twenties, and its expulsion should not be deemed a loss chargeable to the Act. The loss was already there in 1935; it had merely not been realized by actual sales. But dispositions of properties have generally been accomplished with no losses to investors. Just before the divestment plan of UGI was filed in I 942 , its common stock sold at $\$ 4$ per share. This stock rose to $\$ 6$ after the plan was filed and to $\$ 9.88$ before the securities were distributed. Similar market reactions occurred in the case of The Commonwealth \& Southern Corporation, Engineers Public Service Company, and other integration programs. ${ }^{507}$ The record of the past ten years has proved that the apprehension that the Act would cripple the market for utility securities was unfounded. The Commission has not required non-retainable properties to be dumped on the market at sacrifice prices. In fact the Com-

${ }^{507}$ Statistics in this connection are set forth in the I 7 th Annual Report of the Securities \& Exchange Commission, Fiscal year ended June 30, r 95 I, page 70. 
mission claims that the favorable market reception of the portfolio utility stocks that have been sold was an important factor in strengthening the market for utility securities, particularly common stocks. Compliance with the Act has been achieved by other methods also, such as exchanges of securities or properties, the issuance to shareholders of subscription warrants to purchase portfolio securities, or the distribution of portfolio stocks as dividends.

It is generally true that the electric and gas utility industry, from the standpoint of both operating and holding companies, is in a very healthy condition today. Security values have risen, while rates have decreased. This prosperity may well be attributable to the heavy demand for electric and gas services during World War II and the following years of high business activity. Of course, the "dollar" prosperity of the industry must be appraised in the light of the devaluation of the dollar and the insidious inflation of the Roosevelt and Truman administrations, but the large increases in kwh's for the electric business and in mcf's for natural gas operations are testimonials of the well-being of these branches of the utility business. How much credit for this state of affairs can be given to the Act and to the Commission, and how much should be given to extraneous factors such as those just mentioned? The answer is difficult, if not impossible, to find. There is no way to measure the total effect of each factor. It should be borne in mind that the utility holding company is not an evil, per se. It is merely a corporate device with certain features which may be advantageous in some situations and disadvantageous in others, often depending upon whether the viewpoint is that of company officials, investors, consumers, regulatory officials, or the public. Its features which were condemned by Congress were directly attributable to the operators of the device. A utility holding company does not necessarily have to own amusement parks or baseball clubs 
or other miscellany in addition to its utility properties; there is no inherent requirement that it extend its operations over many states and foreign countries; and it is not obliged to resist all attempts at regulation by the states in which it does business. The men in charge were responsible for such conditions. It is perhaps unfortunate that persons such as Insull, Foshay, and Hopson were directing the destinies of the large utility empires at the time of the I 929 crash. However, history contains ample proof of the fact that the characteristics of human nature exemplified by these men are continuously being repeated. Consequently, if there had been no Insull, Foshay, or Hopson, there would probably have been others as bad or worse. And their mistakes, if not curbed, would have been repeated and multiplied as their successors grew in power. The revelations of the great depression might have educated some executives to the evils inherent in the type of corporate insanity prevailing during the twenties. Howard C. Hopson is a shining example of the ineffectiveness of such education. The true measure of the beneficial effects of the Act, therefore, is the extent to which it has induced holding company managements to follow sound economic policies in the administration of their businesses. Reasonable minds will differ, of course, upon the proper definition of sound economic policies. Opponents of the Act were firm in their conviction that management policies were sound before the passage of the Act. An unbiased examination of such policies, however, would reveal many practices in the days before the Act which were undesirable, at least from the standpoint of investors, consumers, and the public with whom Congress was concerned. The Act and its administration by the Commission have imposed a number of substantial obstacles to the cupidity of those in control of utility holding companies. Thus it may be said that the remedy has been directed toward the actual seat of the trouble and that it has 
no doubt contributed in a substantial measure to the present corporate health of the revamped utility holding companies.

Turning now to a more detailed analysis of the interpretation by the Commission and the courts of the specific provisions of the Act relating to integration, it is evident that the requirements pertaining to the single or principal integrated system have been rather liberally construed. The southwestern system of The Middle West Corporation, now known as the system of Central \& South West Corporation, which served an area of 175,500 square miles in four states with transmission lines running $I, 200$ miles from one end of the system to the other, was held to be an integrated electric utility system. And the officially approved integrated electric service area of American Gas \& Electric Company covers seven states and employs gross book assets of over $\$ 750,000,000$, thus making it the largest of the continuing holding companies from the point of financial size. Since interconnection or capability thereof is the prime requisite for the integration of an electrical system, the technological advances in this field have made possible far larger integrated systems than those contemplated by the sponsors of the Act. This development has probably been beneficial in view of the great demand for power experienced by the country during the last decade, but it is somewhat destructive of the requirements of the Act as to limited size and localized management. And economical and coordinated operation is usually a concomitant of extensive interconnections so that compliance with the requirement for such operation has not been difficult for the large systems.

The localized nature of manufactured gas operations has prevented the continuance of any large systems in this field. In addition, this business has not been as attractive from a financial standpoint to the holding companies, and the latter have usually divested or agreed to divest their gas proper- 


\section{8}

ties rather than their electric systems. Further, the advent of long distance natural gas pipe lines, particularly since the end of World War II, has outmoded the artificial gas business in many large areas. The special provision of the Act with regard to natural gas utilities has been liberally construed in favor of the companies. For example, in the case of American Light \& Traction Company, now American Natural Gas Company, it was held that a natural gas system would be integrated even though it derived only $67 \%$ of its supply from a common source. The three principal systems of the Columbia Gas \& Electric Corporation, now The Columbia Gas System, Inc., were held to be separately integrated, although the Commission could easily have held them to be one system, but all three were held to be retainable since they complied with the tests for principal and additional systems. It can be generally stated that the single system provisions of the Act have been much easier to apply to gas utilities than to electric utilities, and therefore litigation with respect to the former has been considerably less than in the case of the latter.

The Commission has been much stricter in its application of the ABC clauses relating to the retention of additional systems. Particularly in the case of Clause A, the Commission has imposed rigid requirements for compliance. It has interpreted the term "loss of substantial economies" to mean the loss of important economies to the integrated system involved, not to the holding company or to the other businesses concerned. These constitute reasonable requirements. In addition, the Commission requires proof of the loss of substantial economies by "clear and convincing evidence." The possibility of increased expenses arising out of separation has been given little weight, and all company estimates of additional expenses and losses of economies have been discounted substantially upon the ground that intangible benefits would be derived by the various properties after separation. This 
theory of intangible benefits upon separation has been applied by the Commission with particular force to proposed combinations of electric and gas utility systems. The Commission is probably justified to a large extent in taking this position, but it imposes a tremendous burden of proof on the holding companies and could well have been modified on occasions where abuse of the gas systems in favor of the electric systems was shown to be absent.

The ambiguity inherent in Clause B of the Act led to a prompt study of the matter by the Commission, which adopted the "one-area" theory as opposed to the "two-area" interpretation urged by the utilities. By virtue of this action, the Commission was able to dispose of many problems merely by reference to a map without the necessity of extended hearings. This ruling was the death knell for the principle of scatteration so well exemplified by most of the large systems.

Geographical requirements for the retention of additional integrated systems are also imposed by Clause $\mathrm{C}$, in that the "area or region" affected must be considered. The test here is relative rather than fixed, as in Clause $\mathrm{B}$, and it is concerned with economic as well as geographical size. The advantages of localized management have often been stressed by the Commission, more so than the other provisions of Clause C. However, the more recent decisions involving Clause $\mathrm{C}$ evidence a rather liberal interpretation of its provisions and the identical provisions in Section 2(a) (29) of the Act.

Textual ambiguities also plagued the Commission with respect to the other businesses clauses. It adopted as the guiding principle the rather narrow test of the first other businesses clause requiring functional and operational relationship between each miscellaneous business and the utility system which sought to retain the other business. The legislative history was not as clear in this case as it was with reference to Clause $\mathrm{B}$, and the Commission would have been 


\section{PUBLIC UTILITY HOLDING COMPANIES}

amply justified in giving independent effect to the second other businesses clause, rather than making it dependent upon and largely subordinate to the operational restriction of the first clause. The economies in operation insisted upon by the Commission under the first other businesses clause are economies in the operation of the integrated utility system and not the other business. Further, the Commission has required that each other business should be minor in importance and size compared to the principal utility business. These tests have been difficult, but not impossible, of attainment and the retention of a large variety of other businesses has been permitted by the Commission.

In spite of the controversial nature of the position taken by the Commission on numerous issues, its decisions relating to Section I I (b) (I) which were litigated in the courts have all been affirmed, with the exception of the other businesses issue in the Engineers Public Service Company case. The commission took the position that the latter case was overruled, in effect, by the Supreme Court in The North American Company case. This was quite possibly an unfounded conclusion on the part of the Commission, but no party has had the temerity to institute another test case, and the matter will undoubtedly remain in the status quo. The judicial approval of the Commission's work with respect to integration constitutes substantial proof of a job well done.

The magnitude of the task being performed by the Commission is indicated by the fact that approximately \$I 6 billion of utility and nonutility properties have already been divested from various holding company systems in conformance with the requirements of Section II, and the number of companies subject to regulation under the Act has been reduced from 2, I 75 to 444, leaving 40 systems with assets of $\$$ I 3 billion. ${ }^{508}$ The Commission estimates that at the con-

${ }^{\cos }$ Id. at $6_{3}-6_{5}$. 
clusion of the Section I I program approximately 20 integrated holding company systems with assets aggregating $\$ 7$ billion will remain subject to regulation. ${ }^{509}$ It thus appears that the Commission has a substantial assignment remaining ahead of it. However, the guideposts have been established in most instances and the problem is not so much how to integrate but how to dispose of non-integrated properties. The Commission has been patient in this regard, and its patience has been well rewarded.

Future integration problems will be concerned with new acquisitions by existing systems, which must meet the requirements of Section IO(c) of the Act. ${ }^{510}$ The comprehensive set of standards which has been examined above should make this task relatively simple. The work of the Commission in this respect will be most effective if it takes advantage of the lesson of the past that its watchful eye should be focused not so much upon the utility systems themselves, but upon the personalities in command of those systems.

And finally, the Commission is now in a position to undertake the studies contemplated by Section 30 of the Act to ascertain the attributes of the most economical and efficient gas and electric utility systems for the nation as a whole..$^{511}$.

\section{${ }^{500} I d$. at 66.}

${ }^{510}$ Section ro (c) of the Act provides that "the Commission shall not approve ( $\mathrm{I}$ ) an acquisition of securities or utility assets, or of any other interest, which is unlawful under the provisions of section 8 or is detrimental to the carrying out of the provisions of section I I ; or (2) the acquisition of securities or utility assets of a public-utility or holding company unless the Commission finds that such acquisition will serve the public interest by tending towards the economical and efficient development of an integrated public utility system. ..."

"Section 30 provides that "The Commission is authorized and directed to make studies and investigations of public-utility companies, the territories served or which can be served by public-utility companies, and the manner in which the same are or can be served, to determine the sizes, types, and locations of publicutility companies which do or can operate most economically and efficiently in the public interest, in the interest of investors and consumers, and in furtherance of a wider and more economical use of gas and electric energy; upon the basis of such investigations and studies the Commission shall make public from time to time its recommendations as to the type and size of geographically and 


\section{PUBLIC UTILITY HOLDING COMPANIES}

In view of the absence of articulate and widespread criticism of electric and gas utility operations at this time, it is extremely doubtful that any legislation of consequence in this field will be enacted in the near future or that such legislation is advisable.

economically integrated public-utility systems which, having regard for the nature and character of the locality served, can best promote and harmonize the interests of the public, the investor, and the consumer. . ." The Commission has recently announced that action pursuant to Section 30 is now in order. Unnumbered release of the Commission dated July $17,1952$. 


\section{APPENDIX}

\section{Compilation of Pertinent Provisions of the Public Utility Holding Company Act of 1935}

SECTION I. (a) Public-utility holding companies and their subsidiary companies are affected with a national public interest in that, among other things, (I) their securities are widely marketed and distributed by means of the mails and instrumentalities of interstate commerce and are sold to a large number of investors in different States; (2) their service, sales, construction, and other contracts and arrangements are often made and performed by means of the mails and instrumentalities of interstate commerce; (3) their subsidiary public-utility companies often sell and transport gas and electric energy by the use of means and instrumentalities of interstate commerce; (4) their practices in respect of and control over subsidiary companies often materially affect the interstate commerce in which those companies engage; (5) their activities extending over many States are not susceptible of effective control by any State and make difficult, if not impossible, effective State regulation of public-utility companies.

(b) Upon the basis of facts disclosed by the reports of the Federal Trade Commission made pursuant to S. Res. 83 (Seventieth Congress, first session), the reports of the Committee on Interstate and Foreign Commerce, House of Representatives, made pursuant to H. Res. 59 (Seventysecond Congress, first session) and H. J. Res. 572 (Seventysecond Congress, second session) and otherwise disclosed and ascertained, it is hereby declared that the national public interest, the interest of investors in the securities of holding com- 
panies and their subsidiary companies and affiliates, and the interest of consumers of electric energy and natural and manufactured gas, are or may be adversely affected-

(I) when such investors cannot obtain the information necessary to appraise the financial position or earning power of the issuers, because of the absence of uniform standard accounts; when such securities are issued without the approval or consent of the States having jurisdiction over subsidiary public-utility companies; when such securities are issued upon the basis of fictitious or unsound asset values having no fair relation to the sums invested in or the earning capacity of the properties and upon the basis of paper profits from intercompany transactions, or in anticipation of excessive revenues from subsidiary public-utility companies; when such securities are issued by a subsidiary public-utility company under circumstances which subject such company to the burden of supporting an overcapitalized structure and tend to prevent voluntary rate reductions;

(2) when subsidiary public-utility companies are subjected to excessive charges for service, construction work, equipment, and materials, or enter into transactions in which evils result from an absence of arm's-length bargaining or from restraint of free and independent competition; when service, management, construction, and other contracts involve the allocation of charges among subsidiary public-utility companies in different States so as to present problems of regulation which cannot be dealt with effectively by the States;

(3) when control of subsidiary public-utility companies affects the accounting practices and rate, dividend, and other policies of such companies so as to complicate and obstruct State regulation of such companies, or when control of such companies is exerted through disproportionately small investment;

(4) when the growth and extension of holding com- 
panies bears no relation to economy of management and operation or the integration and coordination of related operating properties; or

(5) when in any other respect there is lack of economy of management and operation of public-utility companies or lack of efficiency and adequacy of service rendered by such companies, or lack of effective public regulation, or lack of economies in the raising of capital.

(c) When abuses of the character above enumerated become persistent and wide-spread the holding company becomes an agency which, unless regulated, is injurious to investors, consumers, and the general public; and it is hereby declared to be the policy of this title, in accordance with which policy all the provisions of this title shall be interpreted, to meet the problems and eliminate the evils as enumerated in this section, connected with public-utility holding companies which are engaged in interstate commerce or in activities which directly affect or burden interstate commerce; and for the purpose of effectuating such policy to compel the simplification of public-utility holding-company systems and the elimination therefrom of properties detrimental to the proper functioning of such systems, and to provide as soon as practicable for the elimination of public-utility holding companies except as otherwise expressly provided in this title. (I 5 U.S.C.A., Sec. 79a)

SECTION 2. (a) When used in this title, unless the context otherwise requires-

* * *

(3) "Electric utility company" means any company which owns or operates facilities used for the generation, transmission, or distribution of electric energy for sale, other than sale to tenants or employees of the company operating such facilities for their own use and not for resale. The Commission, upon application, shall by order declare a company 
operating any such facilities not to be an electric utility company if the Commission finds that (A) such company is primarily engaged in one or more businesses other than the business of an electric utility company, and by reason of the small amount of electric energy sold by such company it is not necessary in the public interest or for the protection of investors or consumers that such company be considered an electric utility company for the purposes of this title, or (B) such company is one operating within a single State, and substantially all of its outstanding securities are owned directly by another company to which such operating company sells or furnishes electric energy which it generates; such other company uses and does not resell such electric energy, is engaged primarily in manufacturing (other than the manufacturing of electric energy or gas) and is not controlled by any other company; and by reason of the small amount of electric energy sold or furnished by such operating company to other persons it is not necessary in the public interest or for the protection of investors or consumers that it be considered an electric utility company for the purposes of this title. The filing of an application hereunder in good faith shall exempt such company (and the owner of the facilities operated by such company) from the application of this paragraph until the Commission has acted upon such application. As a condition to the entry of any such order, and as a part thereof, the Commission may require application to be made periodically for a renewal of such order, and may require the filing of such periodic or special reports regarding the business of the company as the Commission may find necessary or appropriate to insure that such company continues to be entitled to such exemption during the period for which such order is effective. The Commission, upon its own motion or upon application, shall revoke such order whenever it finds that the conditions specified in clause (A) or (B) are not 
satisfied in the case of such company. Any action of the Commission under the preceding sentence shall be by order. Application under this paragraph may be made by the company in respect of which the order is to be issued or by the owner of the facilities operated by such company. Any order issued under this paragraph shall apply equally to such company and such owner. The Commission may by rules or regulations conditionally or unconditionally provide that any specified class or classes of companies which it determines to satisfy the conditions specified in clause (A) or (B) and the owners of the facilities operated by such companies, shall not be deemed electric utility companies within the meaning of this paragraph.

(4) "Gas utility company" means any company which owns or operates facilities used for the distribution at retail (other than distribution only in enclosed portable containers, or distribution to tenants or employees of the company operating such facilities for their own use and not for resale) of natural or manufactured gas for heat, light, or power. The Commission, upon application, shall by order declare a company operating any such facilities not to be a gas utility company if the Commission finds that (A) such company is primarily engaged in one or more businesses other than the business of a gas utility company, and (B) by reason of the small amount of natural or manufactured gas distributed at retail by such company it is not necessary in the public interest or for the protection of investors or consumers that such company be considered a gas utility company for the purposes of this title. The filing of an application hereunder in good faith shall exempt such company (and the owner of the facilities operated by such company) from the application of this paragraph until the Commission has acted upon such application. As a condition to the entry of any such order, and as a part thereof, the Commission may require application to be made 
periodically for a renewal of such order, and may require the filing of such periodic or special reports regarding the business of the company as the Commission may find necessary or appropriate to insure that such company continues to be entitled to such exemption during the period for which such order is effective. The Commission, upon its own motion or upon application, shall revoke such order whenever it finds that the conditions specified in clauses (A) and (B) are not satisfied in the case of such company. Any action of the Commission under the preceding sentence shall be by order. Application under this paragraph may be made by the company in respect of which the order is to be issued or by the owner of the facilities operated by such company. Any order issued under this paragraph shall apply equally to such company and such owner. The Commission may by rules or regulations conditionally or unconditionally provide that any specified class or classes of companies which it determines to satisfy the conditions specified in clauses (A) and (B), and the owners of the facilities operated by such companies, shall not be deemed gas utility companies within the meaning of this paragraph.

(5) "Public-utility company" means an electric utility company or a gas utility company.

* * *

(7) "Holding company" means-

(A) any company which directly or indirectly owns, controls, or holds with power to vote, Io per centum or more of the outstanding voting securities of a public-utility company or of a company which is a holding company by virtue of this clause or clause (B), unless the Commission, as hereinafter provided, by order declares such company not to be a holding company; and

(B) any person which the Commission determines, after notice and opportunity for hearing, directly or indirectly to exercise (either alone or pursuant to an arrangement or 
understanding with one or more other persons) such a controlling influence over the management or policies of any public-utility or holding company as to make it necessary or appropriate in the public interest or for the protection of investors or consumers that such person be subject to the obligations, duties, and liabilities imposed in this title upon holding companies. The Commission, upon application, shall by order declare that a company is not a holding company under clause (A) if the Commission finds that the applicant (i) does not, either alone or pursuant to an arrangement or understanding with one or more other persons, directly or indirectly control a public-utility or holding company either through one or more intermediary persons or by any means or device whatsoever, (ii) is not an intermediary company through which such control is exercised, and (iii) does not, directly or indirectly, exercise (either alone or pursuant to an arrangement or understanding with one or more other persons) such a controlling influence over the management or policies of any public-utility or holding company as to make it necessary or appropriate in the public interest or for the protection of investors or consumers that the applicant be subjected to the obligations, duties, and liabilities imposed in this title upon holding companies. The filing of an application hereunder in good faith by a company other than a registered holding company shall exempt the applicant from any obligation, duty, or liability imposed in this title upon the applicant as a holding company, until the Commission has acted upon such application. Within a reasonable time after the receipt of any application hereunder, the Commission shall enter an order granting, or, after notice and opportunity for hearing, denying or otherwise disposing of, such application. As a condition to the entry of any order granting such application and as a part of any such order, the Commission may require the applicant to apply periodically for a renewal 
of such order and to do or refrain from doing such acts or things, in respect of exercise of voting rights, control over proxies, designation of officers and directors, existence of interlocking officers, directors and other relationships, and submission of periodic or special reports regarding affiliations or intercorporate relationships of the applicant, as the Commission may find necessary or appropriate to ensure that in the case of the applicant the conditions specified in clauses (i), (ii), and (iii) are satisfied during the period for which such order is effective. The Commission, upon its own motion or upon application of the company affected, shall revoke the order declaring such company not to be a holding company whenever in its judgment any condition specified in clause (i), (ii), or (iii) is not satisfied in the case of such company, or modify the terms of such order whenever in its judgement such modification is necessary to ensure that in the case of such company the conditions specified in clauses (i), (ii), and (iii) are satisfied during the period for which such order is effective. Any action of the Commission under the preceding sentence shall be by order.

(8) "Subsidiary company" of a specified holding company means-

(A) any company ro per centum or more of the outstanding voting securities of which are directly or indirectly owned, controlled, or held with power to vote, by such holding company (or by a company that is a subsidiary company of such holding company by virtue of this clause or clause (B), unless the Commission, as hereinafter provided, by order declares such company not to be a subsidiary company of such holding company; and

(B) any person the management or policies of which the Commission, after notice and opportunity for hearing, determines to be subject to a controlling influence, directly or indirectly, by such holding company (either alone or pursuant 
to an arrangement or understanding with one or more other persons) so as to make it necessary or appropriate in the public interest or for the protection of investors or consumers that such person be subject to the obligations, duties, and liabilities imposed in this title upon subsidiary companies of holding companies.

The Commission, upon application, shall by order declare that a company is not a subsidiary company of a specified holding company under clause (A) if the Commission finds that (i) the applicant is not controlled, directly or indirectly, by such holding company (either alone or pursuant to an arrangement or understanding with one or more other persons) either through one or more intermediary persons or by any means or device whatsoever, (ii) the applicant is not an intermediary company through which such control of another company is exercised, and (iii) the management or policies of the applicant are not subject to a controlling influence, directly or indirectly, by such holding company (either alone or pursuant to an arrangement or understanding with one or more other persons) so as to make it necessary or appropriate in the public interest or for the protection of investors or consumers that the applicant be subject to the obligations, duties, and liabilities imposed in this title upon subsidiary companies of holding companies. The filing of an application hereunder in good faith shall exempt the applicant from any obligation, duty or liability imposed in this title upon the applicant as a subsidiary company of such specified holding company until the Commission has acted upon such application. Within a reasonable time after the receipt of any application hereunder, the Commission shall enter an order granting, or, after notice and opportunity for hearing, denying or otherwise disposing of, such application. As a condition to the entry of, and as a part of, any order granting such application, the Commission may require the applicant to 
apply periodically for a renewal of such order and to file such periodic or special reports regarding the affiliations or intercorporate relationships of the applicant as the Commission may find necessary or appropriate to enable it to determine whether in the case of the applicant the conditions specified in clauses (i), (ii), and (iii) are satisfied during the period for which such order is effective. The Commission, upon its own motion or upon application, shall revoke the order declaring such company not to be a subsidiary company whenever in its judgement any condition specified in clause (i), (ii), or (iii) is not satisfied in the case of such company, or modify the terms of such order whenever in its judgement such modification is necessary to ensure that in the case of such company the conditions specified in clauses (i), (ii), and (iii) are satisfied during the period for which such order is effective. Any action of the Commission under the preceding sentence shall be by order. Any application under this paragraph may be made by the holding company or the company in respect of which the order is to be entered, but as used in this paragraph the term "applicant" means only the company in respect of which the order is to be entered.

(9) "Holding-company system" means any holding company, together with all its subsidiary companies, and all mutual service companies (as defined in paragraph (I3) of this subsection) of which such holding company or any subsidiary company thereof is a member company (as defined in paragraph (14) of this subsection).

* * * *

(29) "Integrated public-utility system" means-

(A) As applied to electric utility companies, a system consisting of one or more units of generating plants and/or transmission lines and/or distributing facilities, whose utility assets, whether owned by one or more electric utility companies, are physically interconnected or capable of physical inter- 
connection and which under normal conditions may be economically operated as a single interconnected and coordinated system confined in its operations to a single area or region, in one or more States, not so large as to impair (considering the state of the art and the area or region affected) the advantages of localized management, efficient operation, and the effectiveness of regulation; and

(B) As applied to gas utility companies, a system consisting of one or more gas utility companies which are so located and related that substantial economies may be effectuated by being operated as a single coordinated system confined in its operations to a single area or region, in one or more States, not so large as to impair (considering the state of the art and the area or region affected) the advantages of localized management, efficient operation, and the effectiveness of regulation: PROVIDED, That gas utility companies deriving natural gas from a common source of supply may be deemed to be included in a single area or region. ( I 5 U.S.C.A., Sec. $79 b$ )

* * *

SECTION 8. Whenever a State law prohibits, or requires approval or authorization of, the ownership or operation by a single company of the utility assets of an electric utility company and a gas utility company serving substantially the same territory, it shall be unlawful for a registered holding company, or any subsidiary company thereof, by use of the mails, or any means or instrumentality of interstate commerce, or otherwise,

(I) to take any step, without the express approval of the State commission of such State, which results in its having a direct or indirect interest in an electric utility company and a gas utility company serving substantially the same territory; or

(2) if it already has any such interest, to acquire without 
the express approval of the State commission, any direct or indirect interest in an electric utility company or gas utility company serving substantially the same territory as that served by such companies in which it already has an interest. (i 5 U.S.C.A., Sec 79h)

SECTION 9. (a) Unless the acquisition has been approved by the Commission under section Io, it shall be unlawful-

(I) for any registered holding company or any subsidiary company thereof, by use of the mails or any means or instrumentality of interstate commerce, or otherwise, to acquire, directly or indirectly, any securities or utility assets or any other interest in any business;

(2) for any person, by use of the mails or any means or instrumentality of interstate commerce, to acquire, directly or indirectly, any security of any public-utility company, if such person is an affiliate, under clause (A) of paragraph (II) of subsection (a) of Section 2, of such company and of any other public utility or holding company, or will by virtue of such acquisition become such an affiliate.

(b) Subsection (a) shall not apply to-

(I) the acquisition by a public-utility company of utility assets the acquisition of which has been expressly authorized by a State commission; or

(2) the acquisition by a public-utility company of securities of a subsidiary public-utility company thereof, provided that both such public-utility companies and all other public-utility companies in the same holding-company system are organized in the same State, that the business of each such company in such system is substantially confined to such State, and that the acquisition of such securities has been expressly authorized by the State commission of such State. 
(c) Subsection (a) shall not apply to the acquisition by a registered holding company, or a subsidiary company thereof, of-

(I) securities of, or securities the principal or interest of which is guaranteed by, the United States, a State, or political subdivision of a State, or any agency, authority, or instrumentality of any one or more of the foregoing, or any corporation which is wholly owned, directly or indirectly, by any one or more of the foregoing;

(2) such other readily marketable securities, within the limitation of such amounts, as the Commission may by rules and regulations prescribe as appropriate for investment of current funds and as not detrimental to the public interest or the interest of investors or consumers; or

(3) such commercial paper and other securities, within such limitations, as the Commission may by rules and regulations or order prescribe as appropriate in the ordinary course of business of a registered holding company or subsidiary company thereof and as not detrimental to the public interest or the interest of investors or consumers. (I 5 U.S.C.A., Sec. 79i)

SECTION Io. (a) A person may apply for approval of the acquisition of securities or utility assets, or of any other interest in any business, by filing an application in such form as the Commission may by rules and regulations prescribe as necessary or appropriate in the public interest or for the protection of investors and consumers. Such application shall include-

(I) in the case of the acquisition of securities, such information and copies of such documents as the Commission may by rules and regulations or order prescribe as necessary or appropriate in the public interest or for the protection of investors or consumers in respect of- 
(A) the security to be acquired, the consideration to be paid therefor, and compliance with such State laws as may apply in respect of the issue, sale, or acquisition thereof,

(B) the outstanding securities of the company whose security is to be acquired, the terms, position, rights, and privileges of each class and the options in respect of any such securities,

(C) the names of all security holders of record (or otherwise known to the applicant) owning, holding, or controlling I per centum or more of any class of security of such company, the officers and directors of such company, and their remuneration, security holdings in, material contracts with, and borrowings from such company and the offices or directorships held, and securities owned, held, or controlled, by them in other companies,

(D) the bonus, profit-sharing and voting-trust agreements, underwriting arrangements, trust indentures, mortgages, and similar documents, by whatever name known, of or relating to such company,

(E) the material contracts, not made in the ordinary course of business, and the service, sales, and construction contracts of such company,

(F) the securities owned, held, or controlled, directly or indirectly, by such company,

$(G)$ balance sheets and profit and loss statements of such company for not more than the five preceding fiscal years, certified, if required by the rules and regulations of the Commission by an independent public accountant,

(H) any further information regarding such company and any associate company or affliate thereof, or its relations with the applicant company, and

(I) if the applicant be not a registered holding company, any of the information and documents which may be required under Section 5 from a registered holding company; 
(2) in the case of the acquisition of utility assets, such information concerning such assets, the value thereof and consideration to be paid therefor, the owner or owners thereof and their relation to, agreements with, and interest in the securities of, the applicant or any associate company thereof as the Commission may by rules and regulations or order prescribe as necessary or appropriate in the public interest or for the protection of investors or consumers; and

(3) in the case of the acquisition of any other interest in any business, such information concerning such business and the interest to be acquired, and the consideration to be paid, as the Commission may by rules and regulations or order prescribe as necessary or appropriate in the public interest or for the protection of investors or consumers.

(b) If the requirements of subsection ( $f$ ) are satisfied, the Commission shall approve the acquisition unless the Commission finds that-

(I) such acquisition will tend toward interlocking relations or the concentration of control of public-utility companies, of a kind or to an extent detrimental to the public interest or the interest of investors or consumers;

(2) in case of the acquisition of securities or utility assets, the consideration, including all fees, commissions, and other remuneration, to whomsoever paid, to be given, directly or indirectly, in connection with such acquisition is not reasonable or does not bear a fair relation to the sums invested in or the earning capacity of the utility assets to be acquired or the utility assets underlying the securities to be acquired; or

(3) such acquisition will unduly complicate the capital structure of the holding-company system of the applicant or will be detrimental to the public interest or the interest of investors or consumers or the proper functioning of such holding-company system.

The Commission may condition its approval of the acquisition of securities of another company upon such a fair offer to 


\section{$3^{1} 8$ PUBLIC UTILITY HOLDING COMPANIES}

purchase such of the other securities of the company whose security is to be acquired as the Commission may find necessary or appropriate in the public interest or for the protection of investors or consumers.

(c) Notwithstanding the provisions of subsection (b), the Commission shall not approve-

(I) an acquisition of securities or utility assets, or of any other interest, which is unlawful under the provisions of section 8 or is detrimental to the carrying out of the provisions of section II ; or

(2) the acquisition of securities or utility assets of a publicutility or holding company unless the Commission finds that such acquisition will serve the public interest by tending towards the economical and efficient development of an integrated public-utility system. This paragraph shall not apply to the acquisition of securities or utility assets of a public-utility company operating exclusively outside the United States.

(d) Within such reasonable time after the filing of an application under this section as the Commission shall fix by rules and regulations or order, the Commission shall enter an order either granting or, after notice and opportunity for hearing, denying approval of the acquisition unless the applicant shall withdraw its application. Amendments to an application may be made upon such terms and conditions as the Commission may prescribe.

(e) The Commission, in any order approving the acquisition of securities or utility assets, may prescribe such terms and conditions in respect of such acquisition, including the price to be paid for such securities or utility assets, as the Commission may find necessary or appropriate in the public interest or for the protection of investors or consumers.

(f) The Commission shall not approve any acquisition as to which an application is made under this section unless it 
appears to the satisfaction of the Commission that such State laws as may apply in respect of such acquisition have been compiled with, except where the Commission finds that compliance with such State laws would be detrimental to the carrying out of the provisions of section I I. (I 5 U.S.C.A., Sec. $79 j$ )

SECTION I r. (a) It shall be the duty of the Commission to examine the corporate structure of every registered holding company and subsidiary company thereof, the relationships among the companies in the holding-company system of every such company and the character of the interests thereof and the properties owned or controlled thereby to determine the extent to which the corporate structure of such holdingcompany system and the companies therein may be simplified, unnecessary complexities therein eliminated, voting power fairly and equitably distributed among the holders of securities thereof, and the properties and business thereof confined to those necessary or appropriate to the operations of an integrated public-utility system.

(b) It shall be the duty of the Commission, as soon as practicable after January I, I938:

( I) To require by order, after notice and opportunity for hearing, that each registered holding company, and each subsidiary company thereof, shall take such action as the Commission shall find necessary to limit the operations of the holding-company system of which such company is a part to a single integrated public-utility system, and to such other businesses as are reasonably incidental, or economically necessary or appropriate to the operations of such integrated publicutility system: PROVIDED, HOWEVER, That the Commission shall permit a registered holding company to continue to control one or more additional integrated public-utility systems, if, after notice and opportunity for hearing, it finds that- 
(A) Each of such additional systems cannot be operated as an independent system without the loss of substantial economies which can be secured by the retention of control by such holding company of such system;

(B) All of such additional systems are located in one State, or in adjoining States, or in a contiguous foreign country; and

(C) The continued combination of such systems under the control of such holding company is not so large (considering the state of the art and the area or region affected) as to impair the advantages of localized management, efficient operation, or the effectiveness of regulation.

The Commission may permit as reasonably incidental, or economically necessary or appropriate to the operations of one or more integrated public-utility systems the retention of an interest in any business (other than the business of a public-utility company as such) which the Commission shall find necessary or appropriate in the public interest or for the protection of investors or consumers and not detrimental to the proper functioning of such system or systems.

(2) To require by order, after notice and opportunity for hearing, that each registered holding company, and each subsidiary company thereof, shall take such steps as the Commission shall find necessary to ensure that the corporate structure or continued existence of any company in the holding-company system does not unduly or unnecessarily complicate the structure, or unfairly or inequitably distribute voting power among security holders, of such holding-company system. In carrying out the provisions of this paragraph the Commission shall require each registered holding company (and any company in the same holding-company system with such holding company) to take such action as the Commission shall find necessary in order that such holding com- 
pany shall cease to be a holding company with respect to each of its subsidiary companies which itself has a subsidiary company which is a holding company. Except for the purpose of fairly and equitably distributing voting power among the security holders of such company, nothing in this paragraph shall authorize the Commission to require any change in the corporate structure or existence of any company which is not a holding company, or of any company whose principal business is that of a public-utility company.

The Commission may by order revoke or modify any order previously made under this subsection, if, after notice and opportunity for hearing, it finds that the conditions upon which the order was predicated do not exist. Any order made under this subsection shall be subject to judicial review as provided in section 24 .

(c) Any order under subsection (b) shall be complied with within one year from the date of such order; but the Commission shall, upon a showing (made before or after the entry of such order) that the applicant has been or will be unable in the exercise of due diligence to comply with such order within such time, extend such time for an additional period not exceeding one year if it finds such extension necessary or appropriate in the public interest or for the protection of investors or consumers.

(d) The Commission may apply to a court, in accordance with the provisions of subsection ( $\mathrm{f}$ ) of section $I 8$, to enforce compliance with any order issued under subsection (b). In any such proceeding, the court as a court of equity may, to such extent as it deems necessary for purposes of enforcement of such order, take exclusive jurisdiction and possession of the company or companies and the assets thereof, wherever located; and the court shall have jurisdiction in any such proceeding, to appoint a trustee, and the court may constitute and appoint the Commission as sole trustee, to hold or 
administer under the direction of the court the assets so possessed. In any proceeding for the enforcement of an order of the Commission issued under subsection (b), the trustee with the approval of the court shall have power to dispose of any or all of such assets and, subject to such terms and conditions as the court may prescribe, may make such disposition in accordance with a fair and equitable reorganization plan which shall have been approved by the Commission after opportunity for hearing. Such reorganization plan may be proposed in the first instance by the Commission, or, subject to such rules and regulations as the Commission may deem necessary or appropriate in the public interest or for the protection of investors, by any person having a bona fide interest (as defined by the rules and regulations of the Commission) in the reorganization.

(e) In accordance with such rules and regulations or order as the Commission may deem necessary or appropriate in the public interest or for the protection of investors or consumers, any registered holding company or any subsidiary company of a registered holding company may, at any time after January I, I936, submit a plan to the Commission for the divestment of control, securities, or other assets, or for other action by such company or any subsidiary company thereof for the purpose of enabling such company or any subsidiary company thereof to comply with the provisions of subsection (b). If, after notice and opportunity for hearing, the Commission shall find such plan, as submitted or as modified, necessary to effectuate the provisions of subsection (b) and fair and equitable to the persons affected by such plan, the Commision shall make an order approving such plan; and the Commission, at the request of the company, may apply to a court, in accordance with the provisions of subsection ( $\mathrm{f}$ ) of section $\mathrm{I} 8$, to enforce and carry out the terms and provisions of such plan. If, upon any such applica- 
tion, the court, after notice and opportunity for hearing, shall approve such plan as fair and equitable and as appropriate to effectuate the provisions of section I I, the court as a court of equity may, to such extent as it deems necessary for the purpose of carrying out the terms and provisions of such plan, take exclusive jurisdiction and possession of the company or companies and the assets thereof, wherever located; and the court shall have jurisdiction to appoint a trustee, and the court may constitute and appoint the Commission as sole trustee, to hold or administer, under the direction of the court and in accordance with the plan theretofore approved by the court and the Commission, the assets so possessed. (I 5 U.S.C.A., Sec. 79k)

* * *

SECTION 30. The Commission is authorized and directed to make studies and investigations of public-utility companies, the territories served or which can be served by public-utility companies, and the manner in which the same are or can be served, to determine the sizes, types, and locations of publicutility companies which do or can operate most economically and efficiently in the public interest, in the interest of investors and consumers, and in furtherance of a wider and more economical use of gas and electric energy; upon the basis of such investigations and studies the Commission shall make public from time to time its recommendations as to the type and size of geographically and economically integrated publicutility systems which, having regard for the nature and character of the locality served, can best promote and harmonize the interests of the public, the investor, and the consumer. The Commission is authorized and directed to make a study of the functions and activities of investment trusts and investment companies, the corporate structures, and investment policies of such trusts and companies, the influence exerted by such trusts and companies upon companies in which they are 


\section{PUBLIC UTILITY HOLDING COMPANIES}

interested, and the influence exerted by interests affiliated with the management of such trusts and companies upon their investment policies, and to report the results of its study and its recommendations to the Congress on or before January 4, I937. (I 5 U.S.C.A., Sec. 79z-4) 


\section{Table of Cases}

American Gas \& Electric Company, Release No. 6333 (December 26, 1945).

$$
79,80,85,90,182,224,253,264,273,282,284,285
$$

American Gas \& Electric Company, Release No. 6639 (May

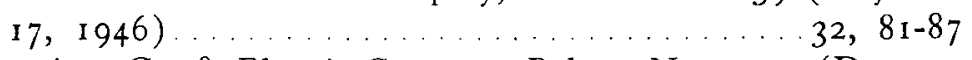

American Gas \& Electric Company, Release No. 7915 (December 10, 1947).

American Gas \& Electric Company, Release No. 10294 (December I9, I950).

American States Public Service Co. In re, I2 F. Supp. 667

(D.C. Md., 1935).

American States Utilities Corporation, 13 S. E. C. 93 (1943)

American Utilities Service Corporation, I6 S. E. C. 173

(1944)

277,287

American Water Works \& Electric Company, 2 S. E. C. 972

(1937) .26, 40, 137, 233, 237, 250, 263, 274, 281, 283, 286 American Water Works \& Electric Company, Release No.

6489 (March 18, 1946)

Appalachian Electric Power Company, Release No. 8173 (April 30, 1948)....................... 253 Appalachian Electric Power Company, Release No. 8285 (June 18, 1948) ...................... 253

Arkansas Natural Gas Corporation v. Securities \& Exchange Commission, 154 F. (2d) 597 (C. C. A., 5th Cir., 1946; cert. denied, 329 U.S. 738) ..........240, 24 I, 253, $26 \mathrm{I}$ Associated Gas \& Electric Company, I5 S. E. C. 743 (1944). I 83 Associated Gas \& Electric Corporation, Release No. 2983 (September 4, I94 I). 203

Associated Gas \& Electric Corporation, II S. E. C. III 5 (1942) $74, \quad 158,203$

Burco, Inc. v. Whitworth, 8I F. (2d) 72 I (C. C. A., 4 th Cir., 1936) 
Central Maine Power Company, I7 S. E. C. 729 (I944) . 268 Central Maine Power Company, Release No. 7985 (February 20, 1948).

Central Power \& Light Company, I4 S. E. C. 452 (I943) . 277 Cities Service Company, i5 S. E. C. 962 (1944).

$$
31,37,108,129,135,141,142,165-
$$

$167,202,223,233,24 \mathrm{I}, 253,257,258,261,282,283$

Cities Service Power \& Light Company, Release No. 4489

(August 17, 1943).

Cities Service Power \& Light Company, I4 S. E. C. 28 (1943) ....31, 36, 51, 53-59, 76, 83, 142, 146, 1 58I6I $203,218,243,244,269,272,273,275,277,283,289$ Cities Service Power \& Light Company, I4 S. E. C. 233 ( I 943) 37,244

Cities Service Power \& Light Company, is S. E. C. 247 ( I944)

Cities Service Power \& Light Company, I5 S. E. C. 675 (1944) $59, \quad$ I $62-164,2$ I 9

Columbia Gas \& Electric Corporation, 8 S. E. C. 443 (I94I) $\ldots \ldots \ldots \ldots \ldots \ldots \ldots \ldots \ldots \ldots$. . . . . . . . . . 35

Columbia Gas \& Electric Corporation, I I S. E. C. 80 (1942)

Columbia Gas \& Electric Corporation, I7 S. E. C. 494 (1 944)
$\ldots \ldots \ldots \ldots \ldots \ldots \ldots \ldots \ldots \ldots \ldots \ldots \ldots \ldots \ldots \ldots \ldots \ldots \ldots \ldots$
37 102,256 99, I02, I 35, I 78, I 79, 203, 222, 223, 245, 256, 262, 282 Commonwealth \& Southern Corporation (The), Release No. I956 (March 6, I940).

Commonwealth \& Southern Corporation (The), Release No. 2626 (March 19, 1941)..........35, 60, 202, 203

Commonwealth \& Southern Corporation (The), Release No. 76 I5 (August I, 1947)

$$
30,60-64,146,161,203,226,243,270
$$

Community Gas \& Power Company, i3 S. E. C. 532 (I943) $99,259,282$

Crescent Public Service Company, Release No. 6 I I 5 (October 9, I 945).

Eastern Utilities Associates, Release No. 9784 (April 4, I 950) 
Electric Bond \& Share Company, 9 S. E. C. 978 (I 941 ) 77 Electric Bond \& Share Company, Release No. $597^{\circ}$ (August $3,1945)$

Electric Bond \& Share Co. v. Securities \& Exchange Commission, 303 U.S. 419 .

Engineers Public Service Company, Release No. 2607 (March I I, I 94 I ) .

Engineers Public Service Company, 9 S. E. C. 764 (I94I) 33, 34, 40, 41, I98-200, 203, 206, 248 Engineers Public Service Company, I2 S. E. C. 4I (I942) $\ldots \ldots \ldots \ldots \ldots \ldots \ldots \ldots \ldots \ldots \ldots \ldots \ldots \ldots \ldots$ I 33,4 I, 43, $49,97,142,148-157$, I 59, I66, I 70, I 73, 203, 2 I I-2 I 5, $235-237,249,267,268,271,275,277,281,283,284$ Engineers Public Service Company, I2 S. E. C. 268 (1942)

Engineers Public Service Company v. Securities \& Exchange Commission, 138 F. (2d) 936 (C. A. D. C., 1943; cert. granted, 322 U.S. 723 ; case moot, 332 U.S. 788 ).

$\ldots \ldots \ldots \ldots \ldots \ldots \ldots \ldots \ldots \ldots \ldots \ldots \ldots \ldots$ 148, I51, I 55, I 68, I 75, 20 I, 203,237,238, 239, 24 I, 242,268,28 I Engineers Public Service Company, In re, I68 F. (2d) 722 C. C. A., 3d Cir., I948) 241

Federal Light \& Traction Company, i5 S. E. C. 675 (I944) $59,162-164,219$

Federal Water \& Gas Corporation, I2 S. E. C. 766 (1943)

Federal Water \& Gas Corporation, Release No. 7945 (December I 8, I 947 ).

General Public Utilities Corporation, Release No. I0982 (December 28, I95 I) . 93, I33, 184-187,253,272, 277, 286, 287 Great Lakes Utilities Company, I I S. E. C. 87 (I942).

Holy Trinity Church v. United States, I 43 U. S. 457 (1892) 


\section{8 PUBLIC UTILITY HOLDING COMPANIES}

Laclede Gas Light Company, I6 S. E. 26 (1944) ...... 30 Lone Star Gas Corporation, I2 S. E. C. 286 (1942).

III, II $2,178,216,217,254,262,282$ Lone Star Gas Corporation, I5 S. E. C. I66 (1942)...... I I 2

Memorandum of January 8, I94I, Re: Interpretation of section II (b) (I) (B) ............. 192-196

Middle West Corporation (The), Release No. 4846 (January

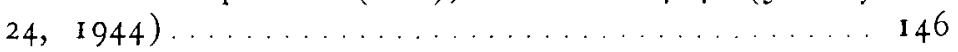

Middle West Corporation (The), 15 S. E. C. 309 (1944) $66-73,75,77,166,168,203,221,253,259,275,277$ Middle West Corporation (The), 18 S. E. C. 296 (1945) $7 \mathrm{I}-73,85,24 \mathrm{I}-243,275,276,278-280$ Middle West Corporation ((The), i 9 S. E. C. 743 (1945). . 281 Middle West Corporation (The), Release No. 6414 (February 18,1946 )

Midland Utilities Company, Release No. 7054 (December

13, 1946)

Mission Oil Company (The), Release No. 10969 (December 2I, I95I).

I 32,259

Morgan Stanley \& Co. v. Securities \& Exchange Commission, I 26 F. (2d) 325 (C. C. A., 2nd Cir., 1942)

New York State Electric \& Gas Corporation, Release No. 8924 (March I I, I 949) I 83,184

North American Company (The), Release No. 3405 (April I4, 1942)

North American Company (The), is S. E. C. I94 (1942) 2 I, 3I, 35, 44, 46-49, 54, 82, 85, 109, I 24, 126, 129, I 3I, I 37, I 39, I 40, I 42, I 58, I68, I 78, 202, 204, 206-2 10, $216,218,232-234,245,250,255,264,265,272,275,284,285$ North American Company (The), i i S. E. C. 715 (1942) $2 \mathrm{I}, 34,279$

North American Company (The), I3 S. E. C. 98 (1943) 
North American Company (The), Release No. 6692 (June I I, I 946)

North American Company (The), Release No. 8626 (November 4, 1948)

233,252

North American Company (The), Release No. 9190 (June 24, 1949)

North American Company (The), Release No. 10320 (December 28, 1950)

North American Company (The) v. Securities \& Exchange Commission, I 33 F.(2d) 148 (C. C. A., 2d Cir., 1943) $22,36,136$, I 39, I 50, I 66, I 68, 234, 237, 242

North American Company v. Securities \& Exchange Commission, 318 U. S. 750 (1943)

North American Company (The) v. Securities \& Exchange Commission, 327 U. S. 686 ( I 946) . . . . 23, I 39, 234, 240 North Continent Utilities Corporation, i4 S. E. C. 656 ( 1943 )

Ohio Power Company, Release No. 7031 (November 27, I 946 )

Ohio Power Company, Release No. 8079 (March 25, I948)

Otis \& Company v. Securities \& Exchange Commission, 323 U. S. 624 (1945)

Panhandle Eastern Pipe Line Company v. Securities \& Exchange Commission, 170 F.(2d) 453 (C. A., 8th Cir., I 948)

Pennsylvania Gas \& Electric Corporation, Release No. 8025 (March 9, 1948)

Pennslyvania Gas \& Electric Corporation, Release No. 8490

(September 3, I948) . ............ I05, 203, 262

Peoples Light \& Power Company, I3 S. E. C. 8I (I943)

Peoples Light \& Power Company, I4 S. E. C. 555 (1943) . . 179

Peoples Light \& Power Company, I5 S. E. C. I 20 (1943)

Peoples Light \& Power Company, 20 S. E. C. 357 (1945) 


\section{0 \\ PUBLIC UTILITY HOLDING COMPANIES}

Philadelphia Company 9 S. E. C. 532 (I 94 I)

Philadelphia Company, Release No. 8242 (June I, I 948)

39, 98, 169-1 73, 187, 204, 241-243, 259, 262, 264, 271, 274 Philadelphia Company, Release No. 8320 (June 30, 1948) . I I 73 Philadelphia Company v. Securities \& Exchange Commission, I 77 F. (2d) 720 (C. A. D. C., 1949) 31, 174, 24I, 243, 27I

Release No. 3 (Sept. 28, 1935) ................. 20

Release No. 22 (Nov. 22, 1935) ............... 20

Release No. IIg2 (Aug. 4, 1938) .............. 21

Release (unnumbered) (July I7, I952) ........... 302

Republic Electric Power Corporation, 3 S. E. C. 992 (1938)

Schechter Poultry Corp. v. U. S., 295 U. S. 495 (1935) ....

Securities \& Exchange Commission, In re, 142 F.(2d) 4 I I

(C. C. A., 3rd. Cir., I944) ................ I1 3

Securities \& Exchange Commission v. Central-Illinois Securities

Corporation, 338 U. S. 96 (1948) .............. 24 I

Sorrells v. United States, 287 U. S. 435 (1932) ........ 199

Southern Union Gas Company, i2 S. E. C. I16 (1942)

Standard Oil Company (New Jersey), 14 S. E. C. 342

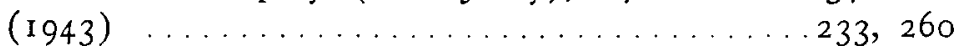

Standard Power \& Light Corporation, 9 S. E. C. 862 (I 94I) $31,38,39,169,204,283$

Texas Utilities Company, Release No. 6373 (January 17, 1946)

United Gas Improvement Company (The), Release No. 2500 (January 1 8, I 941) ........35, 39, 192, 198, 231, 245

United Gas Improvement Company (The), 9 S. E. C. 52 (1941) $\ldots \ldots \ldots \ldots \ldots \ldots 28,39,198,23$ I, 245, 246

United Gas Improvement Company (The), 9 S. E. C. 818

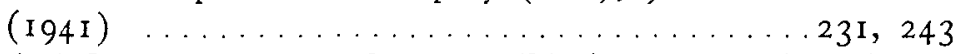

United Gas Improvement Company (The), in S. E. C. $33^{8}$ (1942) 249,269 
United Gas Improvement Company (The), Release No. I 0624 (June 15, I95 I ) . . . . . . . . . . 39, 248 United Gas Improvement Company (The) v. Securities \& Exchange Commission, I 38 F.(2d) Io Io (C. C. A. $3^{\text {rd }}$ Cir., 1943) .........34, 40, 235, 238, 240, 243, 248 United Light \& Power Company (The), Release No. 2820 (June I 3, I 94 I) 231

United Light \& Power Company (The), 9 S. E. C. 833

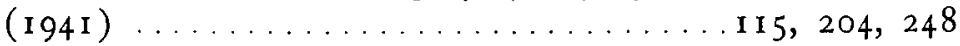

United Light \& Power Company (The), ıо S. E. C. 17 ( I 94 I)

United Light \& Power Company (The), 13 S. E. C. I ( I 943)

United Light \& Power Company, In re, 5I F. Supp. 217 (D. C. Del., I 943)

United Light \& Railways Company (The), I4 S. E. C. 3 ( I 943)

United Light \& Railways Company (The), Release No. 795 I (December 30, 1947) ........ I16, I 20-123, 258, 288 United Public Utilities Corporation, Release No. 3105 (October 3I, I94 I)

United Public Utilities Corporation, I I S. E. C. 33 ( I942)

United States v. American Trucking Association, 3 Io U. S. 534 ( 1 940) 204 204 United States v. Cooper Corporation, 312 U. S. 600 (I941) 199 206

Virginia Electric \& Power Company, 9 S. E. C. 46 I (I94I) 3I, 23 I

West Texas Utilities Company, Release No. 6320 (December 20, I 945) 279 Wisconsin Electric Power Company, 9 S. E. C. 94 I (194I) 


\section{Index}

ABC clauses, 19, 32, 102,135 , I51, I60, 223, 298

Addison Gas \& Power Company, 104

Algonquin Gas Transmission Company, I 32

Allegany Gas Company, 104 Alum Rock Gas Company, IO4 Amarillo Gas Company, I 3 I Amarillo Oil Company, I3I American Gas \& Electric Company, 77, 94, I $81,223,228$, $273,282,284,297$

American Gas \& Power Company, 98

American Light \& Traction Company, 10, I03, I I 2, I 33, I 34, 258, 288, 298

American Natural Gas Company, 298

American Telephone \& Telegraph Company, Io, 287

American Water Works \& Electric Company, 26, 40, $137,262,274,283,294$

Annual Report of the Securities

\& Exchange Commission, 294

Argus Natural Gas Company, I IO, 124, 207, 255

Arkansas Fuel Oil Company, 164

Arkansas Louisiana Gas Company, 107, I08, 164

Arkansas-Missouri Power Corporation, 76

Arkansas Natural Gas Corporation, 253
Associated Gas \& Electric Company, 3, 13, 17, 90, I 82

Austin Field Pipe Line Company, I I $5,25^{8}$

Barkley, Alben W., I9

Barkley Compromise, 196, 289

Black, Hugo L., 23

Blackstone Valley Gas \& Electric Company, I 76

Blum, Robert, "SEC Integration of Holding Company Systems," 205

Bonbright, J. C., and Means, Gardiner C., The Holding Company (I932), 3, 8, I 2 Buchanan, Norman S., "The Public Utility Holding Company Problem," 7

Burton, Harold, 22, 23

Busch, Francis X., GuILTY OR Not Guilty? (1952), I

Capital Transit Company, 264 $\mathrm{CCH}$ Securities Law Reporter, 197

Central \& South West Corporation, 297

Central \& South West Utilities, 66

Central Illinois Public Service Company, 167, 220

Central Ohio Light \& Power Company, 87, 89

Central Power \& Light Company, 67

Charts Showing Location of Operating Electric and/or Gas 


\section{PUBLIC UTILITY HOLDING COMPANIES}

Subsidiaries of Registered Public Utility Holding Companies (1939), 14

Cities Service Company, 2, I07, I $64,253,256,260,28 \mathrm{I}$

Cities Service Gas Company, 256

Cities Service Power \& Light Company, 36, 51, 94, 95, I 57, I64, I $91,217,228$, $269,27 \mathrm{I}, 275,288$

City Light \& Traction Company, 53

Clause A, I 36 ff., 205, 232, 24 I 270, 298

Clause B, IgI ff., 205, 206, 2I0, 2I 4, 289, 299

Clause C, I 95, 205 ff., 299

Clayton Gas Company, I 3 I

Coffman, Paul B., I 70

Cohen, Benjamin V., I 5, 16

Columbia Engineering Corporation, I oo

Columbia Gas \& Electric Corporation, $27,99,178$, I 91 , $222,228,256,262,298$

Columbia Gas System, Inc. (The), 298

Columbus \& Southern Ohio Electric Company, 8I, 94, 95 Commonwealth \& Southern Corporation (The), 60, 95, 224, 228, 269, 294

Commonwealth Edison Company, 2, I 7

Community Gas \& Power Company, 98

Confessions of the Power Trust (I932) by Carl D. Thompson, 2, 3, 7, 10, I3, I 4

Congressional Record, Volume
$79,6,15,16,18,19,160$, 197

Consolidated Edison Co., 17

Constitutionality, I 9, 21, 24

Cooke, Morris L., 9

Corcoran, Thomas G., I 5, I6 Council Bluffs Gas Company, I09

Crystal City Gas Company, I 04

Dalhart Gas Company, I 3 I

Davison, Jas. F., "Death Sentences for Public Utility Holding Companies," 2 I

Death sentence, I6, I 7

Dempseytown Gas Company, I 04

Des Moines Electric Light Company, 47, I 30, 209

Detroit Edison Company, I7, I $13,207,248$

Dewing, Arthur Stone, 7, 9, 12 , I 4

Diversification, I O, I I

Dominion Natural Gas Company, I 88

Douglas, William O., 2I, 22, 23

Douglas, Wm. O., "Scatteration $\mathrm{v}$. Integration of Public Utility Systems," I I , 2 I

Duquesne Light Company, 38

Eastern Utilities Associates, I 75 Edison General Electric Company, I

Edison, Thomas A., I

Electric Bond \& Share Company, I, 2, 6, I 7, 77, 96, 293 "Electric Power Industry, Control of Power Companies," Doc. No. 213, 6gth Cong., 2d Sess., 6 
El Paso Electric Company, 155, 212,268

Engineers Public Service Company, 14, 34, 40, 97, 147, I 70, 19I, 198, 210, 227, $228,234,248,265,27 \mathrm{I}$, $274,280,284,294,300$ Equitable Gas Company, 98

Federal Light \& Traction Company, 59, 2 I 8

Federal Power Commission, I 20, I 22

Federal Trade Commission, 6, 7,303

Financial Policy of CorPORATIONS (1934) by Arthur Stone Dewing, 7, 9, I2, I 4

Fortune Magazine (December, 1945), "Through the Wringer with A. G. \& E.," 4,5

Foshay, Wilbur B., 2, 8, 296

Frank, Jerome N., 197

Frankfurter, Felix, I6, 23

Gas Service Company (The), I07

General Electric Company, I, 6 General Public Utilities Corporation, 90, 132, I 82, 276 , 286

"Geographic Integration under Section I I (b) (I) of the Public Utility Holding Company Act," 28

Glen Echo Park Company, 285 GuIlty or Not Guilty? (1952) by Francis X. Busch, I

Gulf Public Service Company, 277
Gulf States Utilities Company, 4 I , 97, 1 54, 170, I 86, 21 2, 268,274

Hamlin, Scoville, "Is the Utility 'Death Sentence' Unconstitutional?" 2 I

Hartt, Jay Samuel, I 72

Healey, Robert E., 9

Helena Light \& Railroad Company, I 43

H. Hearings on H. R. 5423, 74th Cong., Ist Sess. (I 935), I0, 14, 16, 93, 94, 96, I 50 H. J. Res. No. 572, 72 nd Cong., 2d Sess. (1933), 7

Holding Company (The) (1932) by J. C. Bonbright and Gardiner C. Means, 3, 8 , I 2

Hopson, Howard C., 3, 8, 14 , I 82,296

H. R. Report No. 1903, 74th Cong., Ist Sess. (1935), 30, 33, 137

H. Res. No. 59, 72nd Cong., Ist Sess. (I 932), 7

Hughes, Charles Evans, Jr., 22

Ickes, Harold L., 9

Illinois Iowa Power Company, 47,209

Illinois Power Company, I 39

Illinois Traction Company, 47, 264

Indiana \& Michigan Electric Company, 86

Indiana Service Corporation, 86, 89

Insull, Samuel, I, 8, 14, 293, 296

Internal Revenue Code, 244 


\section{$33^{6}$ PUBLIC UTILITY HOLDING COMPANIES}

Iowa Power \& Light Company, 47,130

Iowa Union Electric Company, I 24

Jackson, Rohert, 22, 23

Jersey Central Power \& Light

Company, 91, I32, I 85

Jome, "The New Schoolmaster in Finance," $2 \mathrm{I}$

Kansas City Gas Company, 107 Kentucky Utilities Company, I 67,220

Kentucky West Virginia Gas Company, 98

Kewanee Public Service Company, 47 , I 39

Lake Superior District Power Company, 66, 167,220

Landis, James M., 20

Las Vegas Light \& Power Company, 56

Legislative history, I 5-19

Lesser, L. S., "Constitutional Powers of the Securities \& Exchange Commission over Public Utility Holding Companies," 21

Lilienthal, David E., 9

Lone Star Gas Corporation, I09, I 24 I34, I77, 216, $227,254,261$

Madison Gas \& Electric Company, I 13

Main Street and WaLl Street ( I932) by Wm. Z. Ripley, 3, 7, 10 Mange, John I., 4 Markham, Edward M., 9 McNinch, Frank R., 9 Mead, Elwood, 9
Means, Gardiner Co., and Bonbright J. C., The Holding Company (1932), 3, 8, I 2 Metropolitan Edison Company, 9I

Michigan Consolidated Gas Company, I I 3

Michigan-Wisconsin Pipe Line Company, I I 3,258

Middle West Corporation (The), 64, 94, 95, I67, $220,227,228,276,277$, 297

Middle West Utilities Company, 2, I 7

Midland United Company, 2, 220

Midland Utilities Company, 86 Milwaukee Gas Light Company, I I 3

Milwaukee Solvay Coke Company, II 4,288

Minneapolis Gas Light Company, 98

Minton Amendment, 236, 239, 289

Mission Oil Company (The), I 3 I

Missouri Power \& Light Company, 49

Mitchell, Sidney Z., I

Montana Public Utilities Commission, 143

Murphy, Frank, 22, 23

National Power Policy Committee, 8

Natural Gas Pipe Line Company of America, 257

New Hampshire Public Service Commission, I 42

New Jersey Power \& Light Company, 9I 
New Mexico Eastern Gas Company, I05

New Mexico Gas Company, I05

New Mexico Power Company, 56

New York State Electric \& Gas Corporation, I 82

Norcross, T. W., 9

North American

Company

(The), 10, 21, 23, 24, 35, $44,123,134,137,170,191$, 202, 206, 216, 218, 228, $231,233,240,250,254,263$, $272,280,285,290,300$

North American Light \& Power Company, 109, I 24

Northern Natural Gas Company, I09, I24, 207, 254

Northern Pennsylvania Power Company, 9 1, 93, I 83

North Penn Gas Company, 104

Ogden Corporation, 140

Oklahoma Power \& Water Company, 67, I 68

Panhandle Eastern Pipe Line Company, I02, I I3, I I6, I $23,256,258$

Pecos Valley Power \& Light Company, 67

Pennsylvania Electric Company, 90

Pennsylvania Gas \& Electric Corporation, I03

Penn-York Gas Company, io8 Peoples Gas Light \& Coke Company, 2

Peoples Light \& Power Company, 179,285

Peoples Natural Gas Company, I IO, I 24, 207
Philadelphia Company, 10, 38 , $97,169,186,242,270,273$ Pittsburgh \& West Virginia Gas Company, 98

Prendergast, William A., 8

Principal System, 33

Public Service Company of Colorado, 54, 166, 218

Public Service Company of Oklahoma, 67

Public Utilities and the

People (I 933) by William A. Prendergast, 8

Public Utility Act of 1935, H. R. Report No, $1318,74^{\text {th }}$ Cong., Ist Sess. (1935), I 7 , I 8

Public Utility Act of 1935, Senate Report No. 62 I, 74th Congress, Ist Sess., 8, I 8, 82, 208, 2I I, 2I 8

Public Utility Holding Company Act of 1935:

Section I-303

Section I (a) - 247

Section I (b)-I95, 210 , $232,242,247$

Section I (c) - 32

Section 2(a) (3)-305

Section 2(a) (4)-I 24, 307

Section 2(a) (5)-308

Section 2(a) (7)-308

Section 2(a) (8)-23I, 244, $245,249,310$

Section 2(a) (9)-312

Section 2(a) (29) -25, 37 $48,58,72,80,82,83,88$, 93,96, I 06, I I 1, 1 12, I $21,123,126,128,129$, 133, I 34, I60, 194, 195, 205, 206, 216, 218, 221, $223,225,226,228,299$, 312 
Section $8-27,3$ I, 3 I3

Section 9-246, 3 I 4

Section $10-32,81,82,87$,

I $79,246,249,270,301$,

3 I 5

Section II (a) $-246,3$ I9

Section I 1 (b) ( I) - 32, 33, 80, 93, I02, III, I 26 , 1 $30,132,135,159,184$, I 99, 208, 225, 230, 232, $236,239,242,245,248$, $249,259,285,289,29 \mathrm{I}$, 300,319

Section I I (b) (2) -320

Section I I (c) - 36, 233, 32 I Section I I (d) - 32 I

Section II (e)-33, I05, II $2,115,136,219,241$, 322

Section $13-282$

Section I $4-282$

Section 30-3OI, 323

Pyramids of Power (I937) by M. L. Ramsay, I-4, 6, 16, 17

Ramsay, M. L., Pyramids of POWER (1937), I-4, 6, I6, I 7

Rawlins Electric Company, I 59 Rayburn, Sam, I 5

Red River Gas Company, I 3 I "Relation of Holding Companies to Operating Companies in Power and Gas Affecting Control" (1932-I933), 7

Republic Electric Power Corporation, I 36

Republic Light, Heat \& Power Company, Inc., 108

Ripley, William Z., 7
Ripley, Wm. Z., Main Street aNd Wall Street (I927), $3,7,10$

Roberts, Owen, 22

Rochester Gas \& Electric Corporation, 183

Roosevelt, Franklin D., 5, 9, I 5, 23, 295

Rutledge, Wiley, 23

St. Joseph Railway, Light, Heat \& Power Company, $15^{8}$

St. Louis County Gas Company, I 24, I 40, I 70, I 86

Savannah Electric \& Power Company, r53, 2 10, 268

Scatteration, I I, I 3

Scranton Electric Company (The), 90

"Section I I (b) of the Holding Company Act: Fifteen Years in Retrospect," 7

S. Hearings on S. I 725, 74th Cong., Ist Sess. (I935), Io, I $5,16,96,150$

South Carolina Power Company, 225

Southern Union Gas Company, I 05, I 34, 2 I 5, 274, 288

South Jersey Gas Company, I 32 Southwestern Gas \& Electric Company, 67

Southwestern Light \& Power Company, 67

Standard Gas \& Electric Company, 38,169

Standard Oil Company of New Jersey, 260

Standard Power \& Light Corporation, $38,97,169$ 
Stone, E. C., 172

Stone, Harlan, 22, 23

Texas Eastern Transmission Corporation, 132

Texas Public Service Company, 179

Texas Southwestern Gas Company, 106

Texoma Natural Gas Company, 257

Thompson, Carl D., ConfesSIONS OF THE Power TRUST (1932), 2, 3, 7, 10, 13, 14 "Through the Wringer with A.G. \& E.," Fortune Magazine (December, I945), 4 , 5

Toledo Edison Company, 157

Transcontinental Gas Pipe Line Corporation, 132

Truman, Harry S., 295

Tucson Gas, Electric Light \& Power Company, 219

Twin State Gas \& Electric Company, I 42

Union Colliery Company, 250 Union Electric Company, 44, $46,49,123,140,250,263$ United Electric Securities Company, 10

United Gas Improvement Company, 9, 28, 39, 192, I97, $238,245,294$

United Light \& Power Company (The), II 3, 204
United Light \& Railways Company, 8I, I 09, I I 2, I 24, 258 United Public Utilities Corporation, $87,89,204$

United States Bureau of Reclamation, 59, I60, I6I, I62

Virginia Electric \& Power Company, 97, 147, I 53, I 70, 186, 210, 2I3, 2I 4, 265, 277

Wall Street Journal, 22

Washington Railway \& Electric Company, 264

Waterman, Merwin H., "Economic Implications of Public Utility Holding Company Operations," I 2

Waverly Electric Light \& Power Company (The), 93 West Kentucky Coal Company, 250

West Texas Gas Company, I 31 West Texas Utilities Company, 67

Wheeler, Burton K., I5, I8, 197

Wheeler-Rayburn bill, 5, 6

Willkie, Wendell L., "The Future of the Holding Company," Io

Wisconsin Power \& Light Company, 66, 167, 220

Wyandotte County Gas Company (The), Io7 